\title{
The Last Resort: Building Big Architecture in Big Landscapes
}

Cameron Suisted

A 120 point thesis submitted to the Faculty of Architecture and Design, Victoria University of Wellington, in partial fulfillment of the requirements for the degree of Master of Architecture (Professional) 


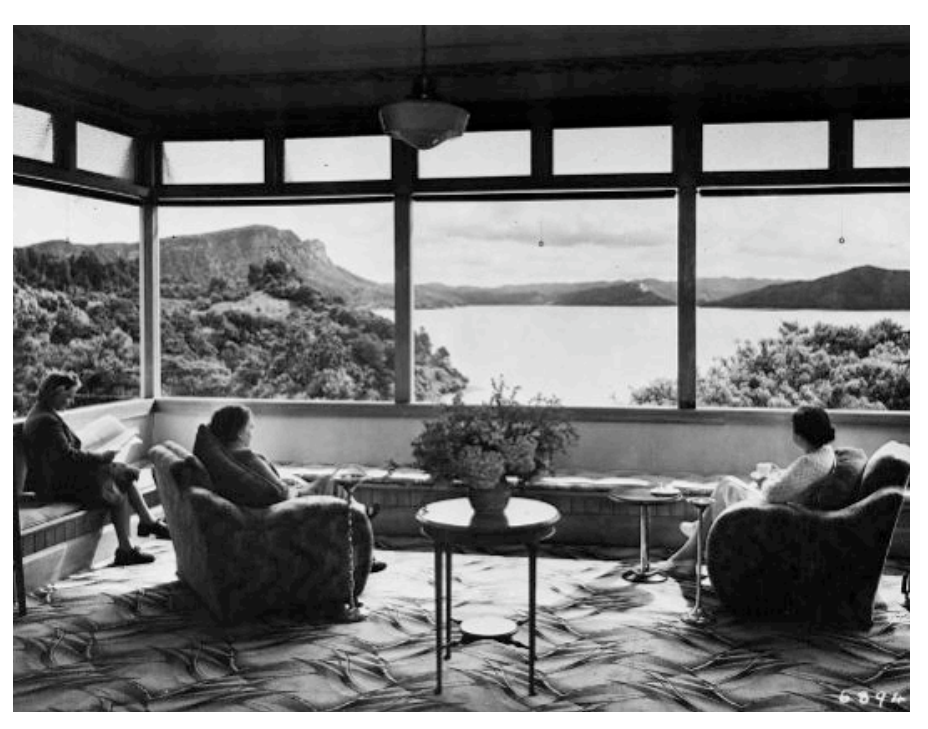

ii. Lake House Hotel. (1901-1976). Waikaremoana, New Zealand.

Retrieved from Ref: 1/2-040280-F. Alexander Turnbull Library, Wellington, New Zealand. http://natlib.govt.nz/records/23120741

\section{Acknowledgments}

Firstly, thank you Sam Kebbell for your critical expertise, guidance, enthusiasm and support throughout the year.

Thanks to my grandparents, Donald and Helen Black and Roy and Joan Suisted, who both coincidentally honeymooned at the Lake House Hotel, leading me to this site.

Finally, thanks to all my friends and family for the support and encouragement throughout the year. 


\section{The Last Resort: Building Big Architecture in Big Landscapes}

Cameron Suisted

2013

A 120 point thesis submitted to the Faculty of Architecture and Design, Victoria University of Wellington, in partial fulfillment of the requirements for the degree of Master of Architecture (Professional) 


\section{Abstract}

Accommodating large groups of people typically requires large architecture. However, in precious landscapes, such as National Parks, large architectural interventions are often opposed on the grounds of an aesthetic cost to the landscape. Most of the building activity that has attracted this opposition detracts from the natural environment by both dominating the landscape and being indifferent to it. In attempts to mitigate aesthetic damage, other buildings are composed in such a way that is 'sympathetic' with the landscape. Employing strategies of fragmentation, dispersion, miniaturization, and camouflage, the ideal of these approaches is an invisible building. But because no building is invisible, this is an unproductive direction for the discipline. The high-end resort typology would require a relatively large footprint and would suffer the same critique as the approaches noted above. What strategies do architects need to take to develop large buildings in the landscape that are neither invisible nor an aesthetic expense? And, in the pursuit of large architectural interventions, how can these operations enhance the qualities of the landscape, such that the landscape is made more intelligible, more spectacular, more powerful or more dramatic?

Forming the first section of this thesis, a proposed high-end resort development at Waikaremoana critically explores formal solutions that enhance the Urewera landscape. Employing a research through design methodology, a critical analysis of both problematic and exemplary precedents has unearthed a range of formal strategies that enhance and detract from the landscape respectively. A 'before and after' comparison technique has been employed throughout this analysis - and the design process - to determine whether the interventions strengthen or weaken the landscape. In response to the densely forested site, the scheme employs cutting as a general formal gesture - generating both an ecological and cultural cross section through the site, while providing pedestrian access from road to lake. Developed through an intuitive design process, the scheme has tested the architectural possibilities of occupying a cut and how such an intervention may enhance the dramatic qualities of the landscape.

Highlighting the intellectual implications of the issues raised throughout the design process, a written argument forms the second section of this thesis. This proposition looks to the cutting formal traditions of land-art, particularly of the 1960s-70s, for insight into architectural forms that enhance the landscape. Reading the cut as "not landscape" and "not architecture," Rosalind Krauss's (1979) "Sculpture in the Expanded Field" provides a starting platform for this inquiry. Several overlooked cutting interventions within Te Urewera build on this knowledge, rethinking various aspects of the cut and how it can operate to enhance the landscape. Providing connectivity, security and a place for confrontation, a cutting formal strategy offers opportunities to enhance both architecture and the landscape. 


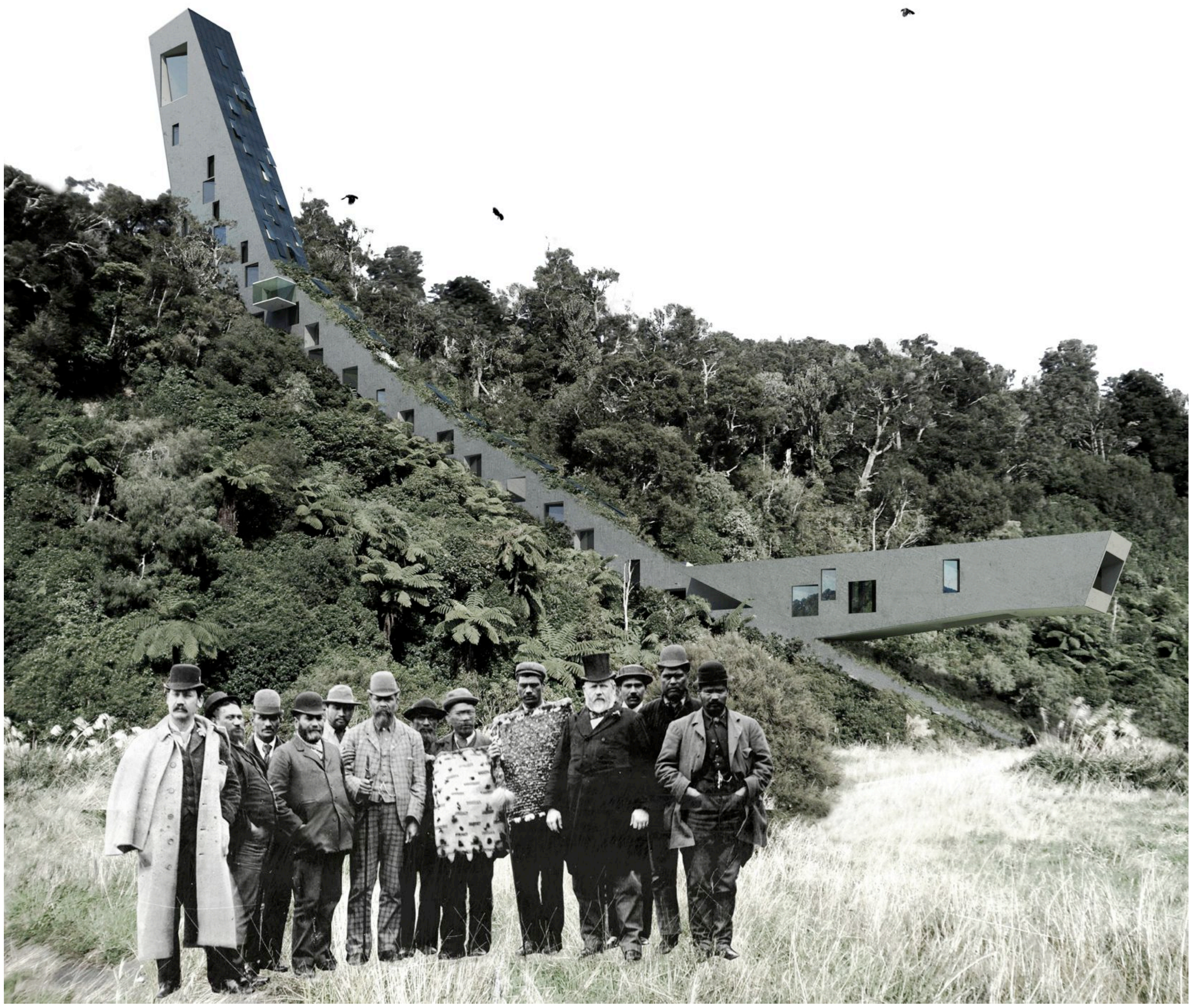

i Occupying the Landscape: Arriving from Lake 


\title{
Contents
}

\author{
Page Content \\ Acknowledgments \\ Abstract
}

\section{Part One: The Scheme}

Page Content

101.0 Problem and Location

111.1 Problem Statement

$14 \quad 1.2$ Location

202.0 Occupying the Landscape

323.0 Occupying the Cut

$48 \quad 4.0$ Occupying the Resort

$65 \quad 5.0$ Appendix

$66 \quad 5.1$ Site Analysis

$70 \quad 5.2$ Density Comparisons

725.3 Process 


\section{Part Two: The Paper}

Page Content

826.0 Problem:

836.1 Problem Statement:

856.2 Research Question:

867.0 Proof of Problem:

867.1 Unresponsive to Landscape:

$90 \quad 7.2$ Formal Mimicry:

$92 \quad 7.3$ Formal Dilution:

\subsection{Exemplars:}

968.1 Objects on the Landscape:

1008.2 Interventions on the Landscape:

1049.0 Theoretical Implications:

1059.1 The Expanded Field:

1119.2 Infrastructure in the Expanded Field:

1219.3 Border Control:

1279.4 Defence Strategies:

1339.5 Construct/Destruct:

13710.0 Possibilities:

138 11.0 List of Figures:

14412.0 Reference List: 
Part One: The Scheme 


\subsection{Problem + Location}
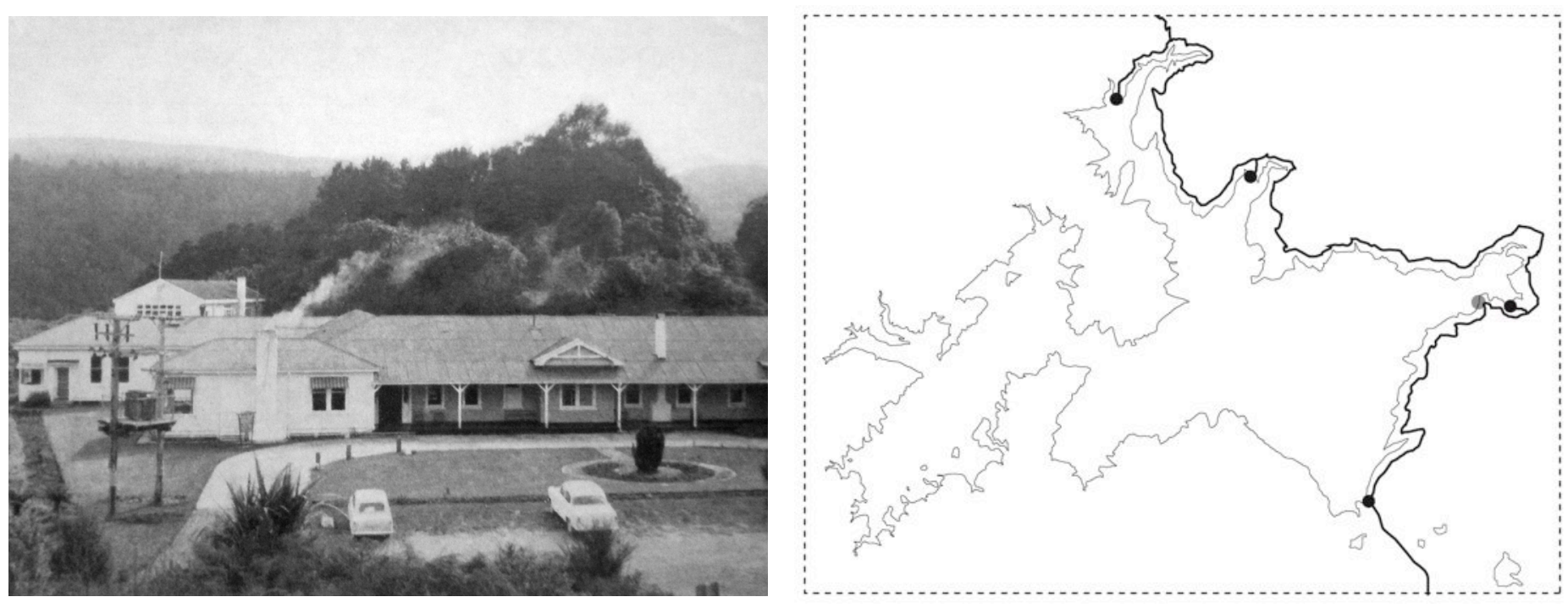

1.1 Formal Problem: Historic Development Failed to Enhance the Landscape, Lake House Exterior, (1977).

In Gallen, R. (1977). A souvenir booklet of Waikaremoana, Wairaumoana, Waikareiti: a concise history of the lakes, the people and the land. Hamilton,
New Zealand: Urewera National Park Board.
1.2 Formal Problem: Access to Lake Waikaremoana.

1.3 Formal Problem: Lake Access from Road.

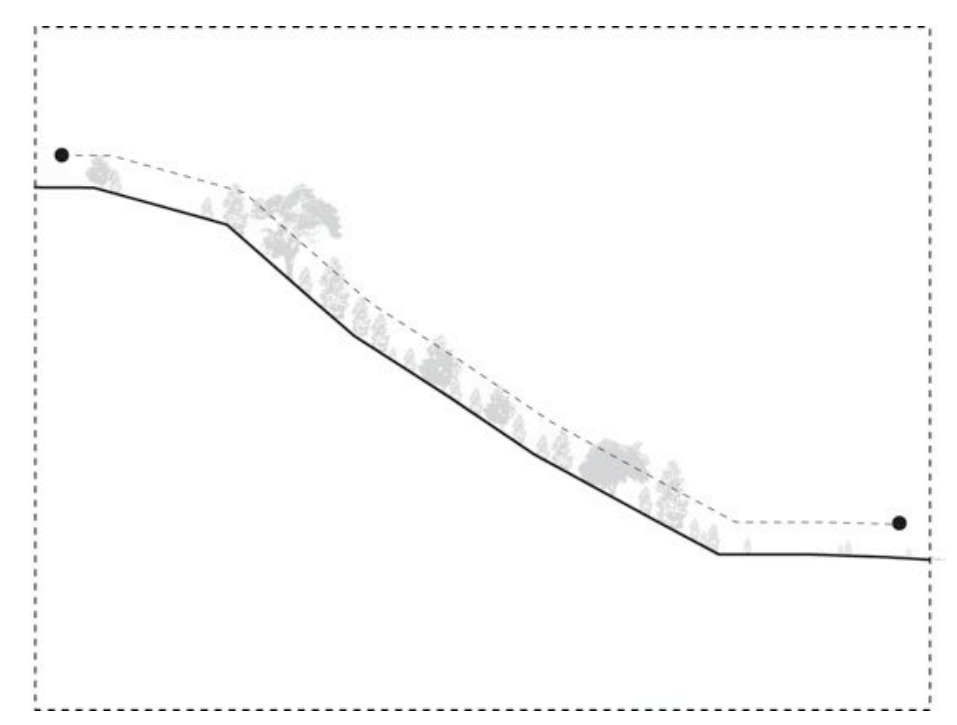




\subsection{Problem Statement}

\section{Formal:}

The primary formal objective of this scheme is to make the landscape stronger - not weaker - through an architectural intervention. This investigation is to take place at Waikaremoana (Fig 1.11), deep within Te Urewera National Park, through the design of a high end resort. Located atop a mountainous area of native forest, the site was previously occupied by the Lake House Hotel (1903-1970). This sprawling and adhoc building failed to enhance the landscape (Fig 1.1). The dense mountainous landscape surrounding Lake Waikaremoana limits outlooks of the lake and restricts access to only four locations - each of which are dominated by vehicles (Fig 1.2). From within the site, pedestrian access to the lake is non-existent (Fig 1.3).

These problems require a formal solution that not only enhances the landscape, but also better connects people to the landscape and the lake. Dwelling within the indigenous landscape, the building should encourage inhabitants to better understand the landscape, beyond the conventional 'image' normally presented to tourists.

\section{Cultural:}

Within Waikaremoana there is widespread disconnection between visiting and local communities. Restricting social interaction, national park legislation ensures only three locals currently live within the park boundary (Fig 1.4 and 1.5). The resort typology, typically employed in such environments, also conventionally separates the interaction of visitors and hosts (Fig 1.7). While not only unproductive, the separation of the host community - of which $70 \%$ are Māori - and the predominantly Pakeha visitors intensifies culturally divisive approaches of occupying New Zealand landscapes. This divide was recently captured in a survey for the prospects of customary harvesting of native species, as over 80 percent of Māori respondents approved the submission, while 78 percent of non-Māori were opposed (Fig 1.6).

Within this culturally divided landscape, architecture should not attempt to resolve cultural divisions, but rather accommodate the expression of cultural difference. This requires a design solution that better connects visitors and hosts. 
34,206

3

hosts who live in Waikaremoana in 2012

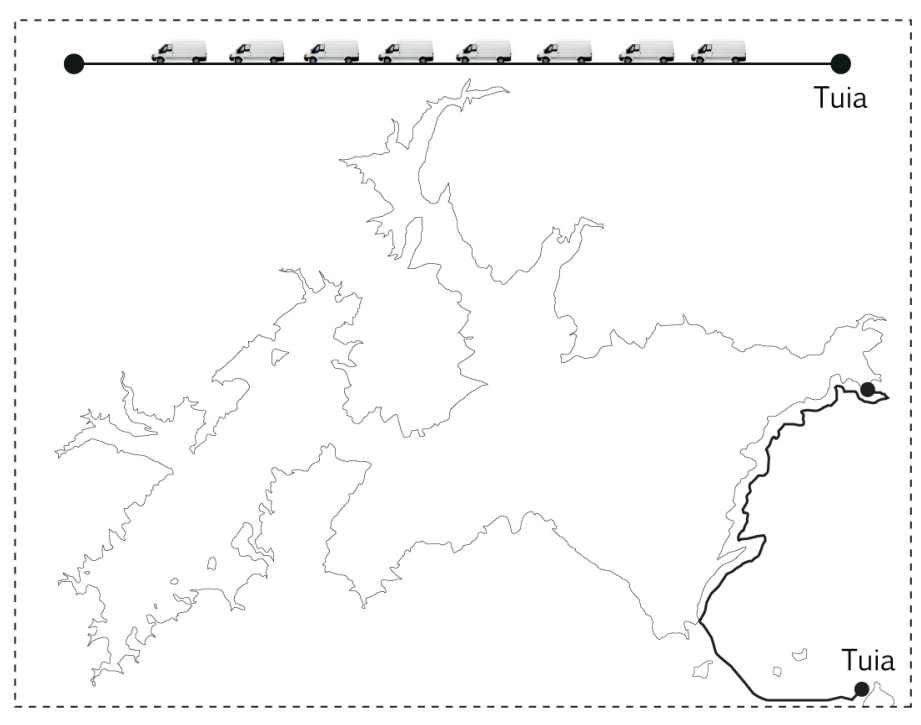

1.5 Social Problem: Disconnection of Host Community from Lake Waikaremoana.

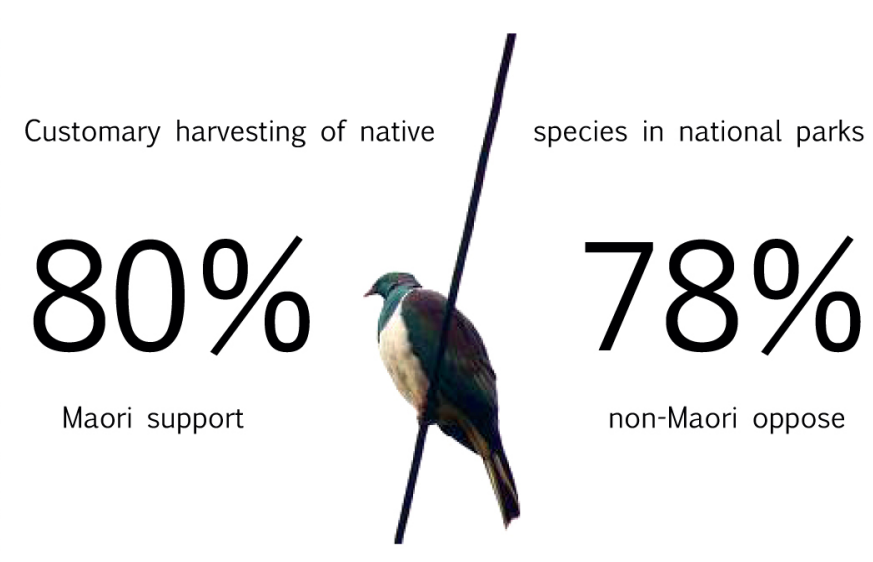

1.6 Social Problem: Cultural Differences Between Local (70\% Maori) and Visiting Communities. 


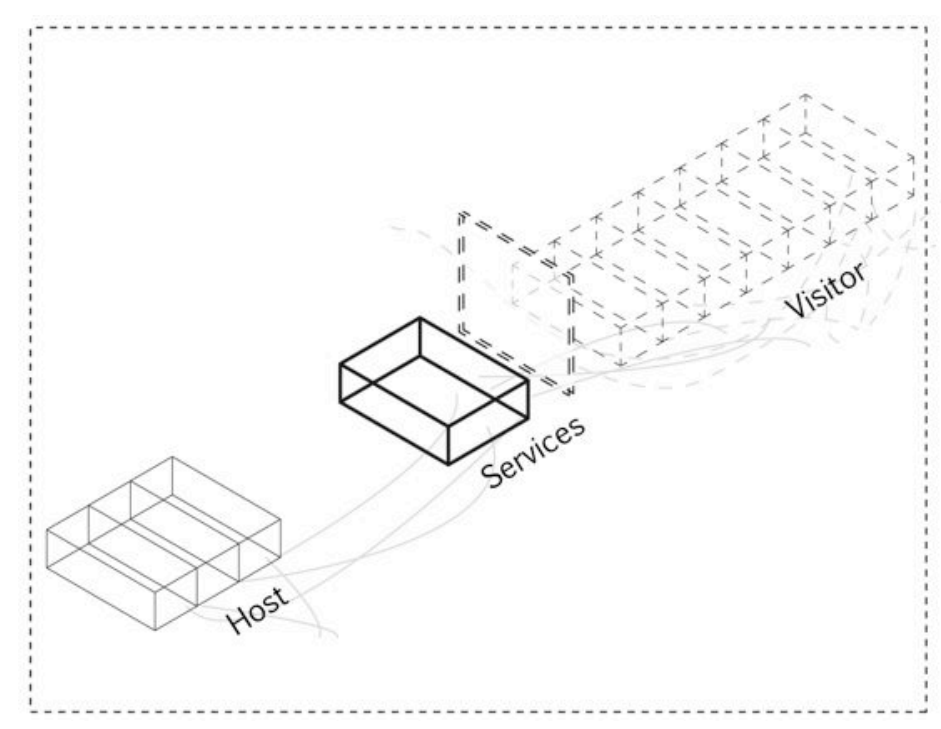

1.7 Social Problem: Disconnection Between Visitors and Hosts within Resort Typology.

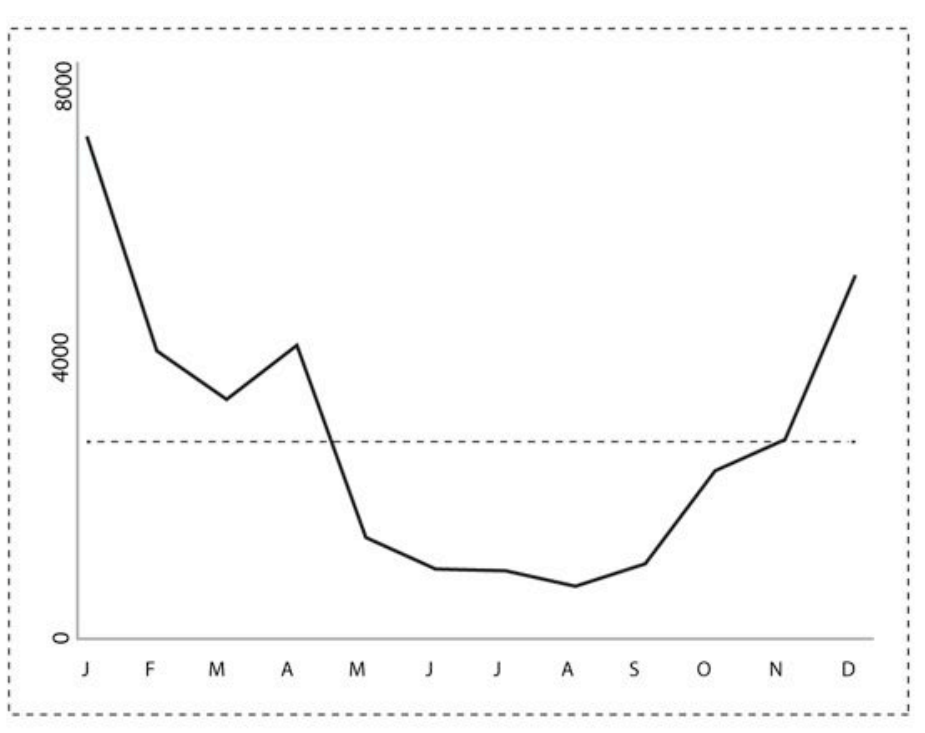

1.8 Social Problem: Visitor Fluctuations within Te Urewera National Park (2011).

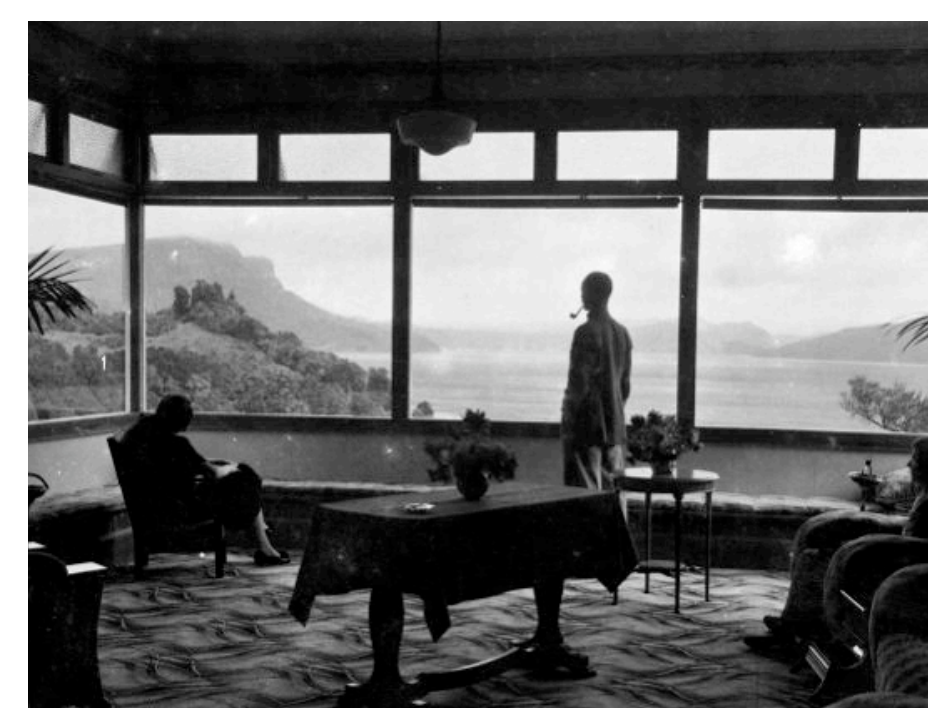

1.9 Social Problem: The Tourist Image of Waikaremoana, Lake House interior, (1950).

In Park, G. (2007). Theatre country: Essays on landscape and whenua. Wellington, New Zealand. Victoria University Press. 


\subsection{Location}

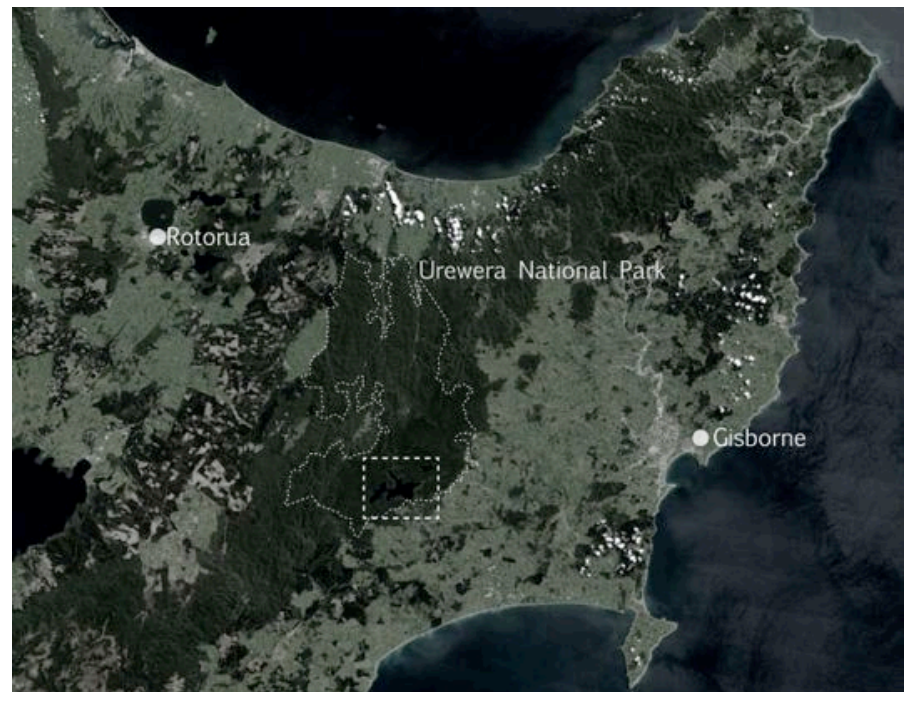

1.10 Location: Te Urewera National Park Retrieved from www.maps.google.co.nz.

$\begin{array}{ll}\stackrel{k m}{4} & 25\end{array}$
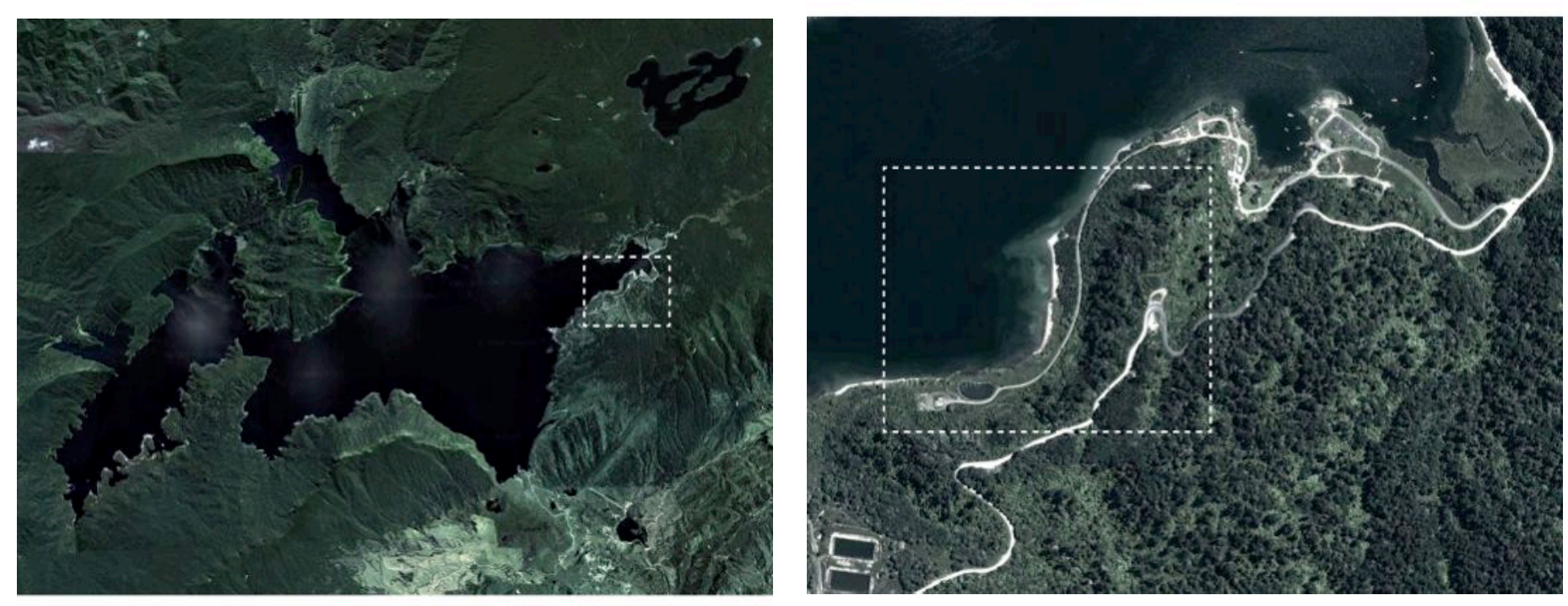

1.11 Location: Lake Waikaremoana Retrieved from www.maps.google.co.nz. $\stackrel{\llcorner\mathrm{km}}{0} 2$

1.12 Location: Home Bay

Retrieved from www.maps.google.co.nz $\stackrel{\text { m }}{\stackrel{5}{0} 100}$ 


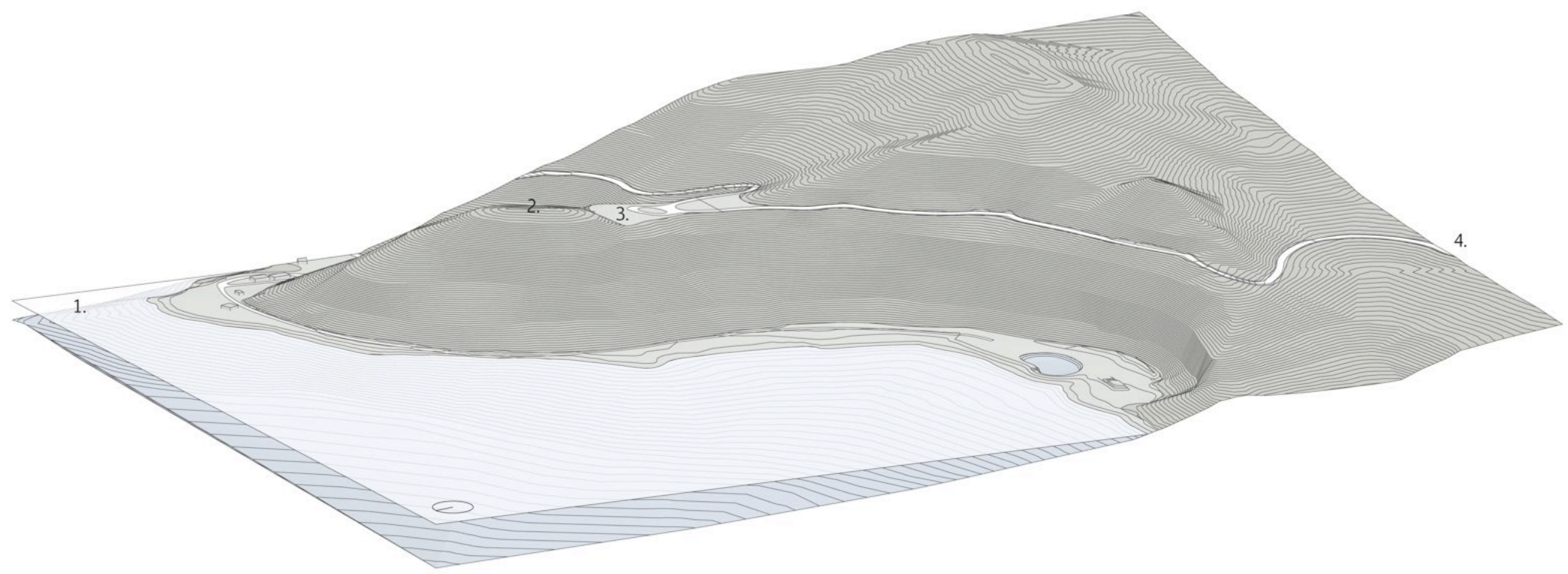

Legend:

Lake Waikaremoana

Dense native forest

Grass

1. Road to motor camp

Home Bay hill (77m above lake)

Historic Lake-hotel site (1901-1974)

Lake Road (State Highway 38) 


\section{Formal Solution:}

In response to the densely forested site, the scheme employs cutting as a general formal gesture - generating both an ecological and cultural cross section through the site, while providing pedestrian access from road to lake. 


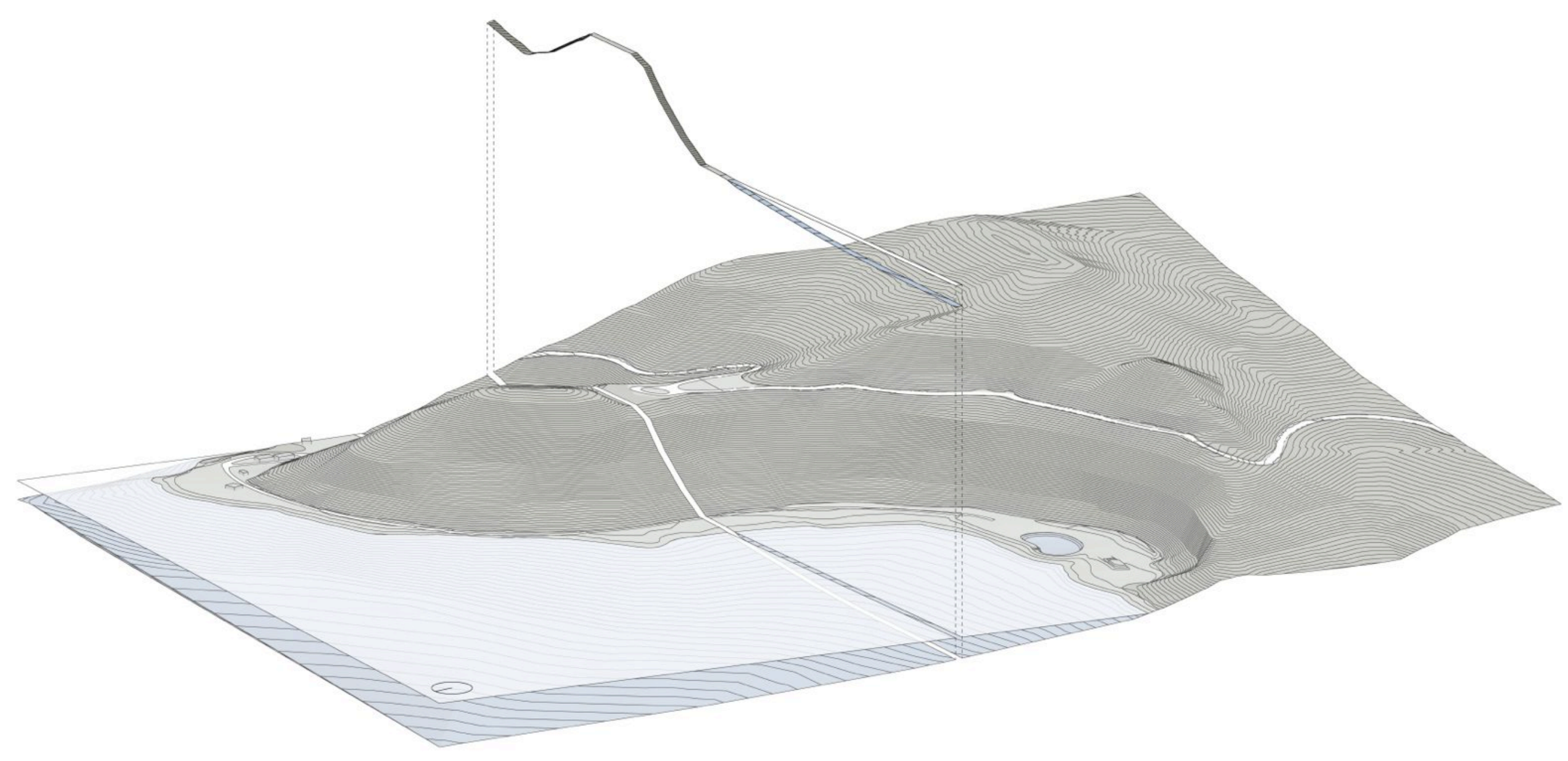


1. Lake Road (State Highway 38) Reception / car park entrance Observation lounge

Lecture theatre entrance

Cable car

Restaurant + bar

Lake Waikaremoana

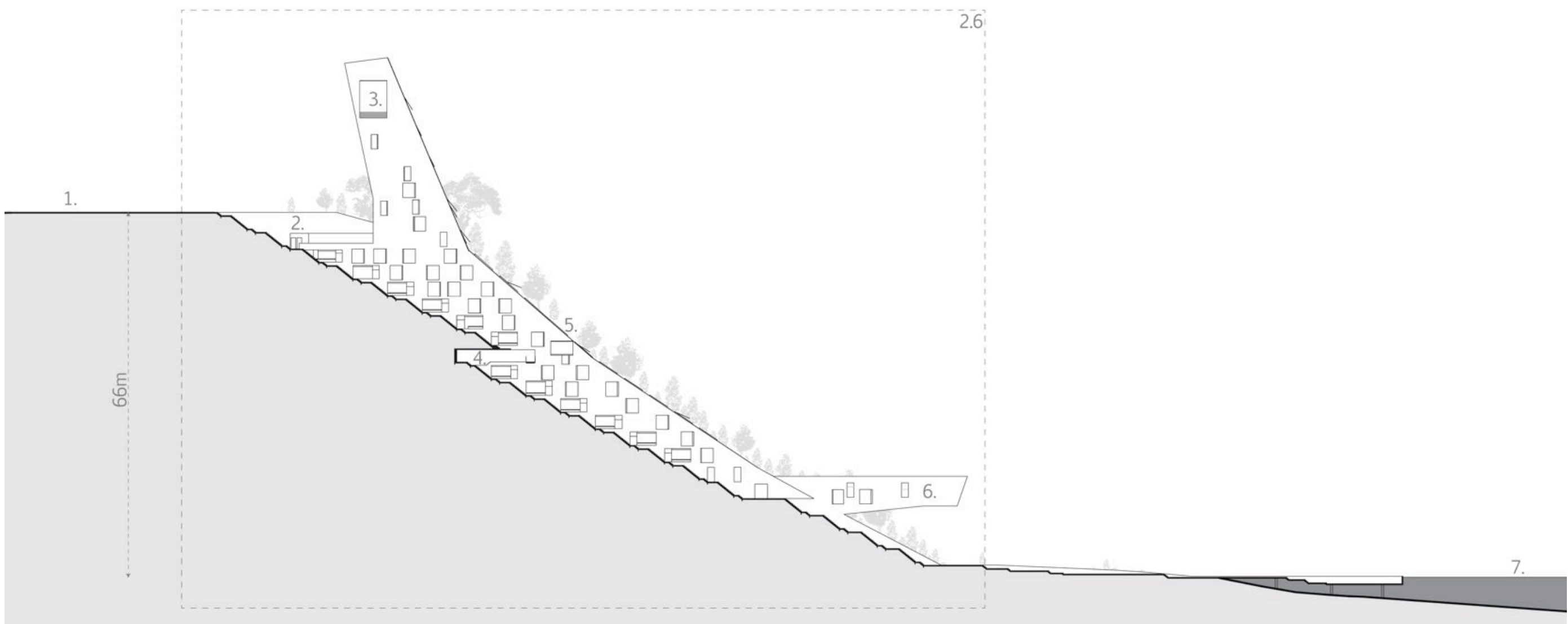

$215 m$ 


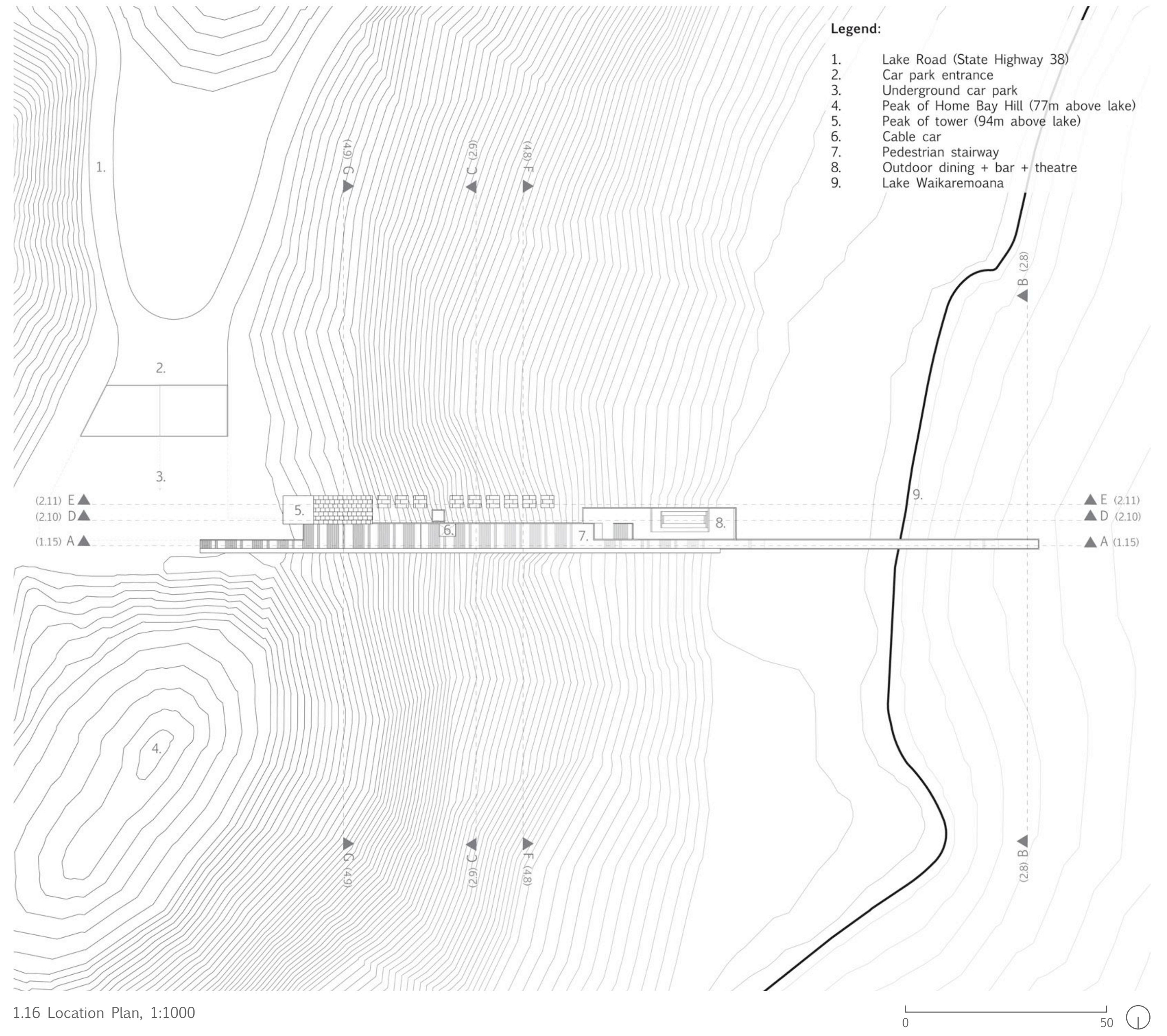




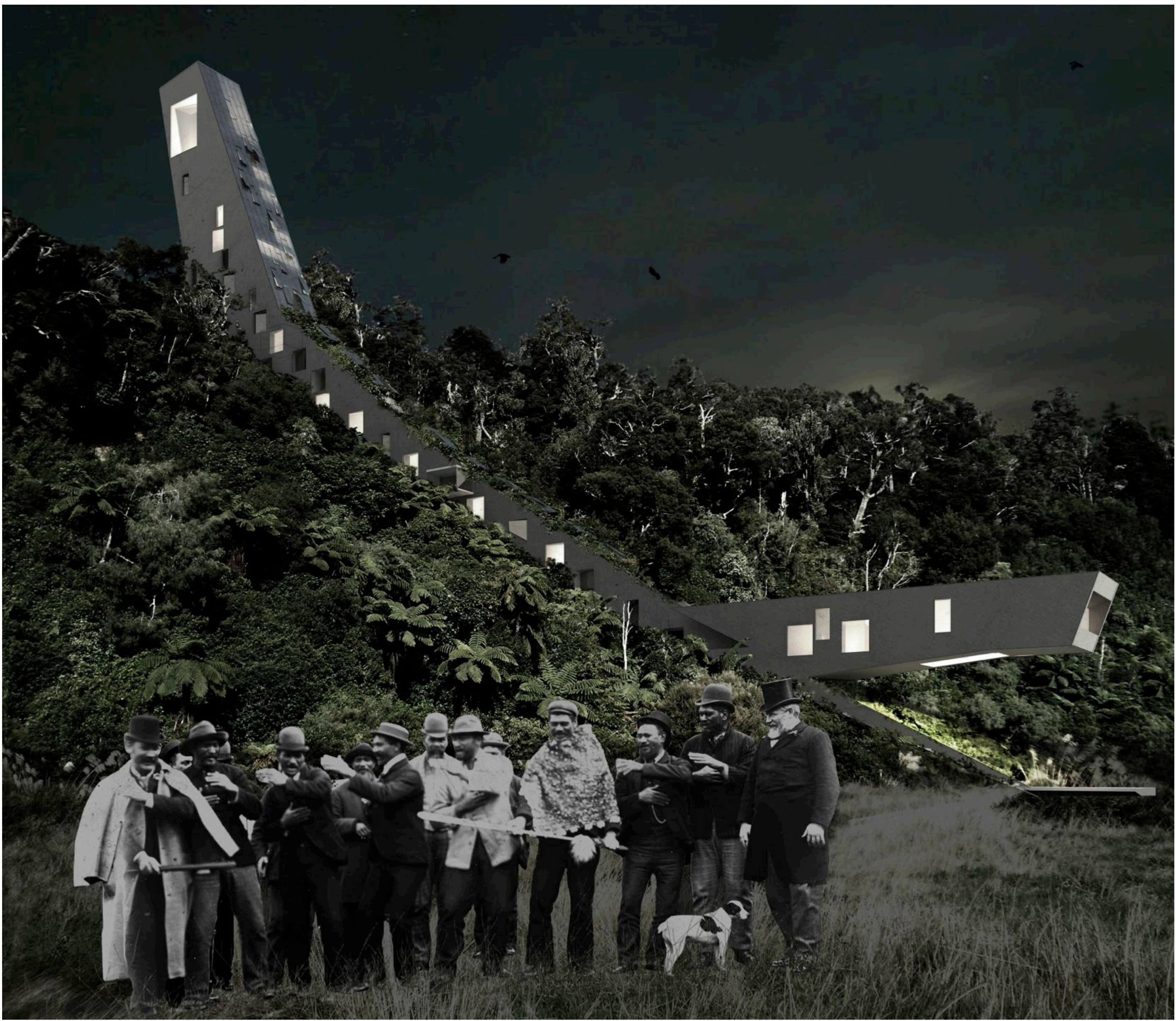




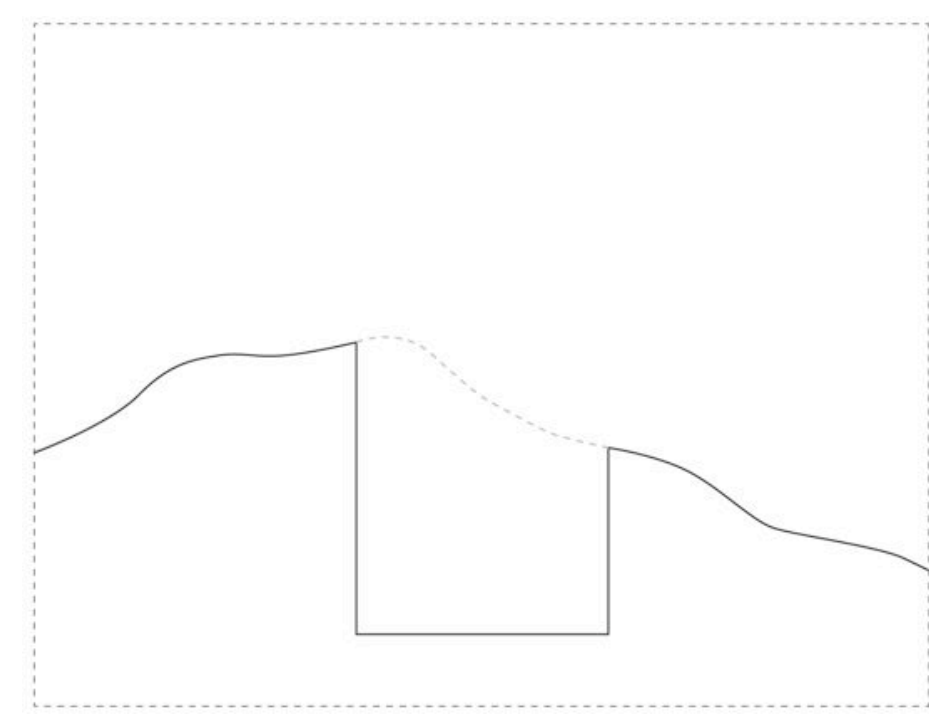

2.2 Formal solution: The cut.

\subsection{Occupying the Landscape}

Employing a $6 \mathrm{~m} \times 215 \mathrm{~m}$ cut to open up the landscape, the intervention allows circulation in an otherwise densely forested environment. Generating a precise break in the landscape (Fig 2.5), the cut provides pedestrian access from road to lake in the form of an open stairway and covered cable car. The cut provides an ecological cross section through the site, encouraging visitors to gain a deeper understanding of the landscape beyond the superficial 'image' normally presented to tourists.

Rising 94 meters above the lake, the tower confronts the landscape and identifies the site as a cultural centre (Fig 2.4). Providing a vertical cross section through the forest canopy, the tower strengthens the connection between inhabitants and the ecological systems of the site. 


.

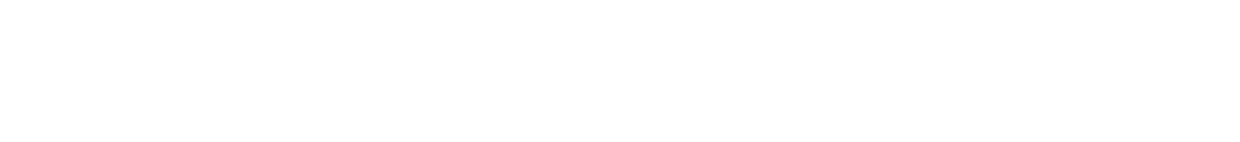

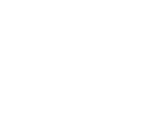

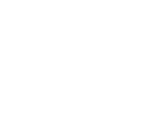
$\sqrt{1}$

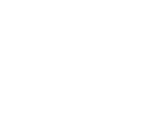
(

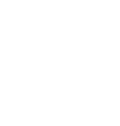

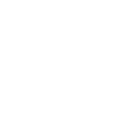

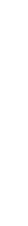

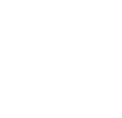
C 


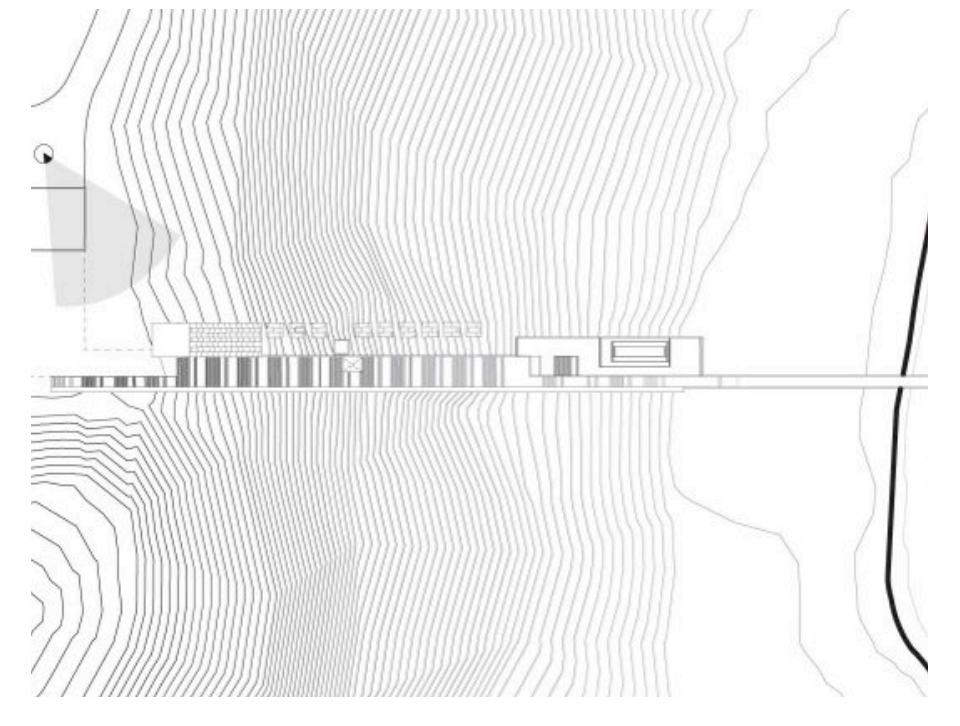

2.3 Occupying the Landscape: Entrance from Lake Road (State Highway 38)

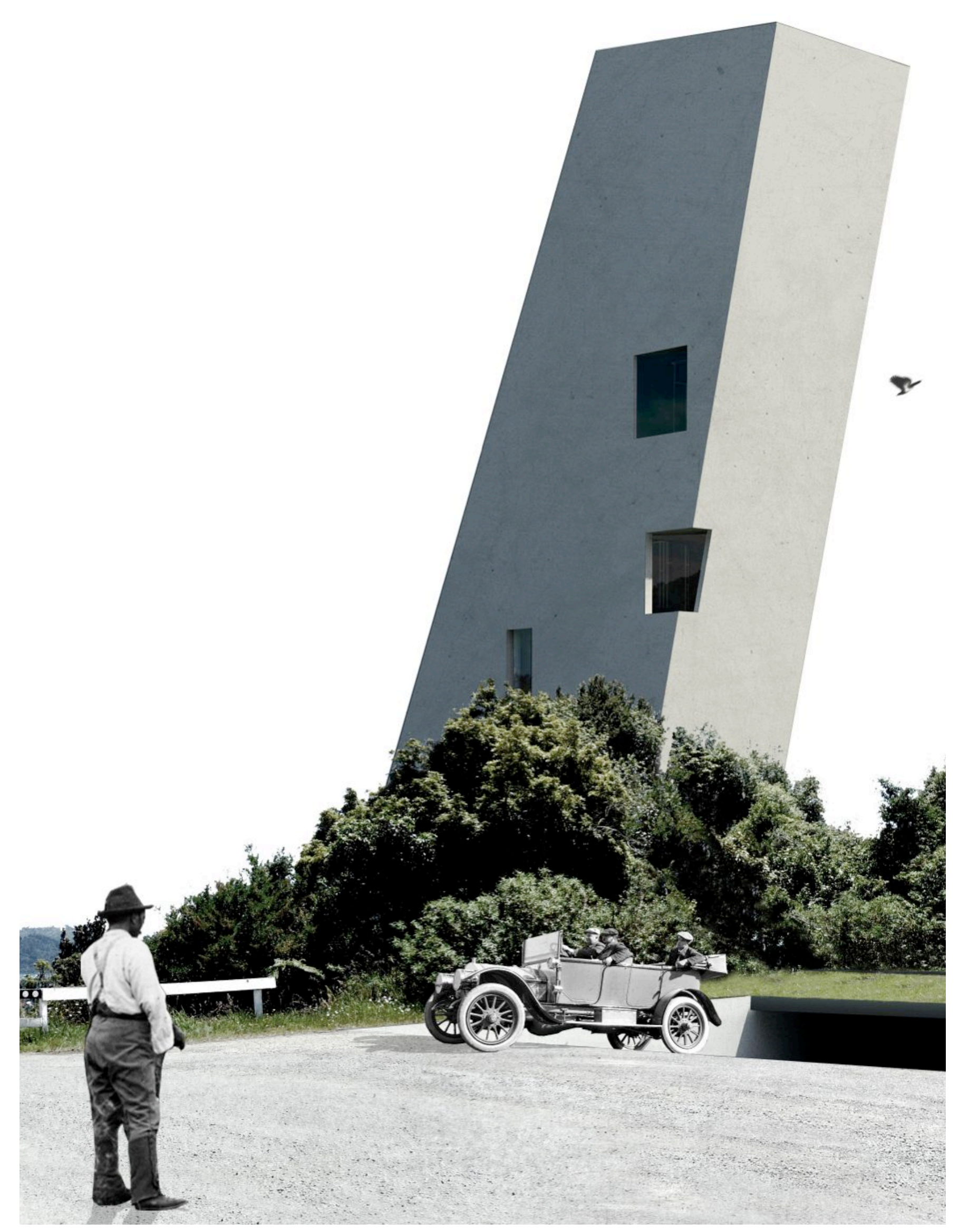




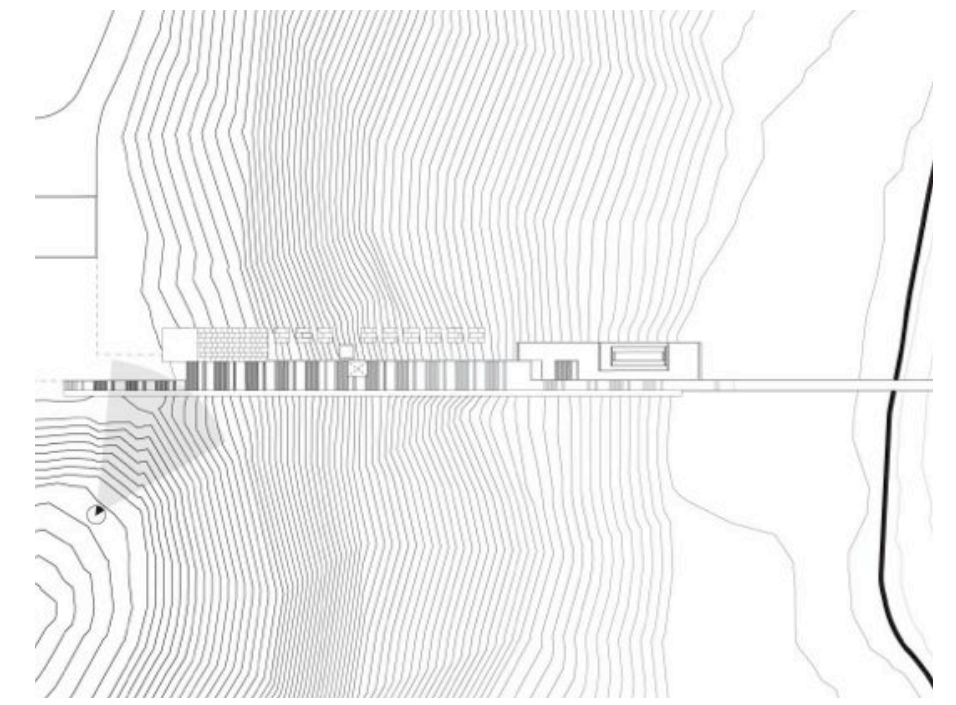

2.4 Occupying the Landscape: Home Bay Hill View

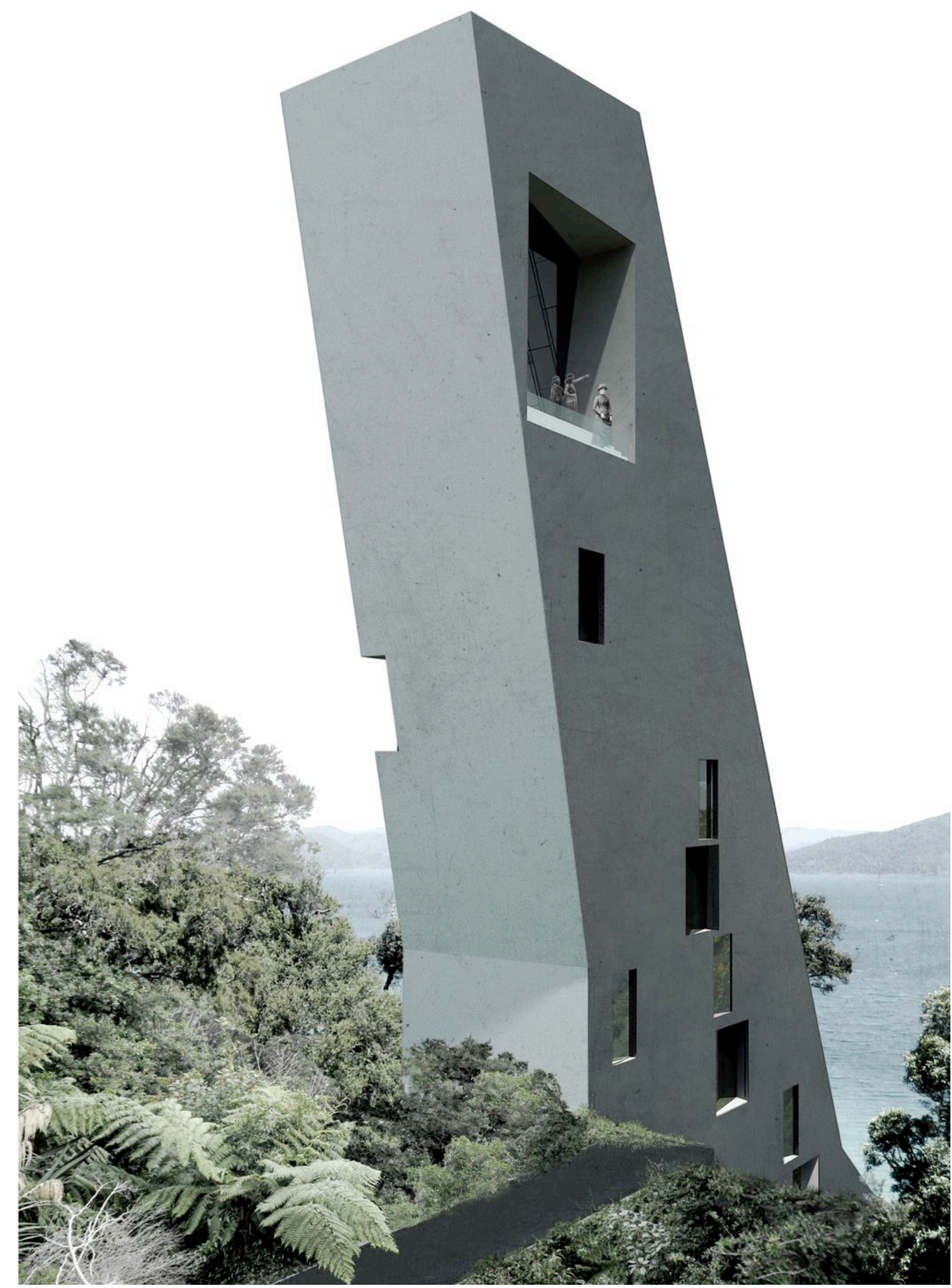




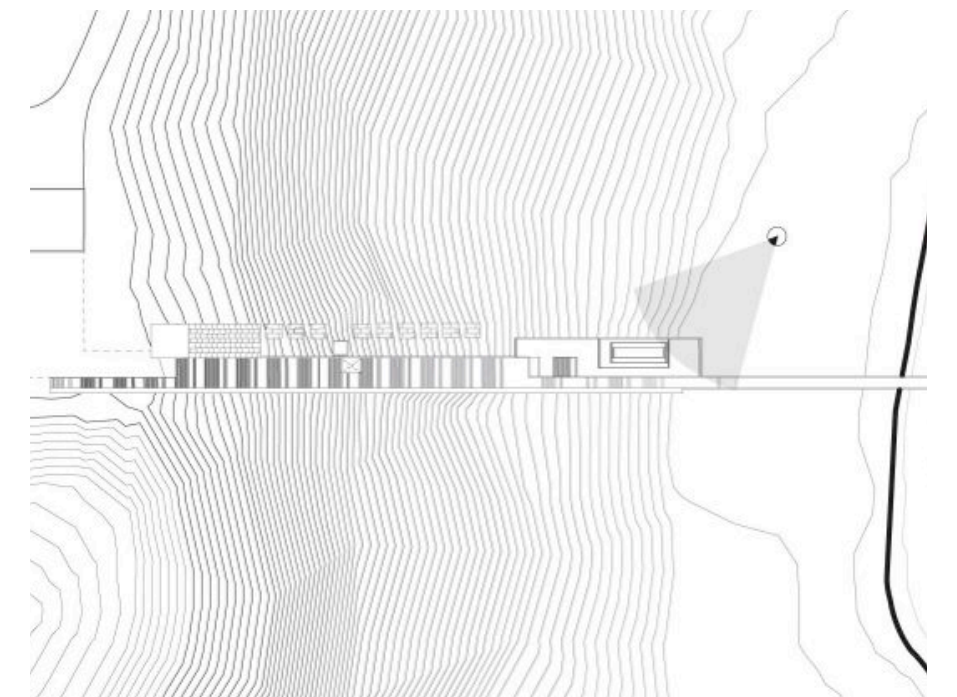

2.5 Occupying the Landscape: Entrance from Lake

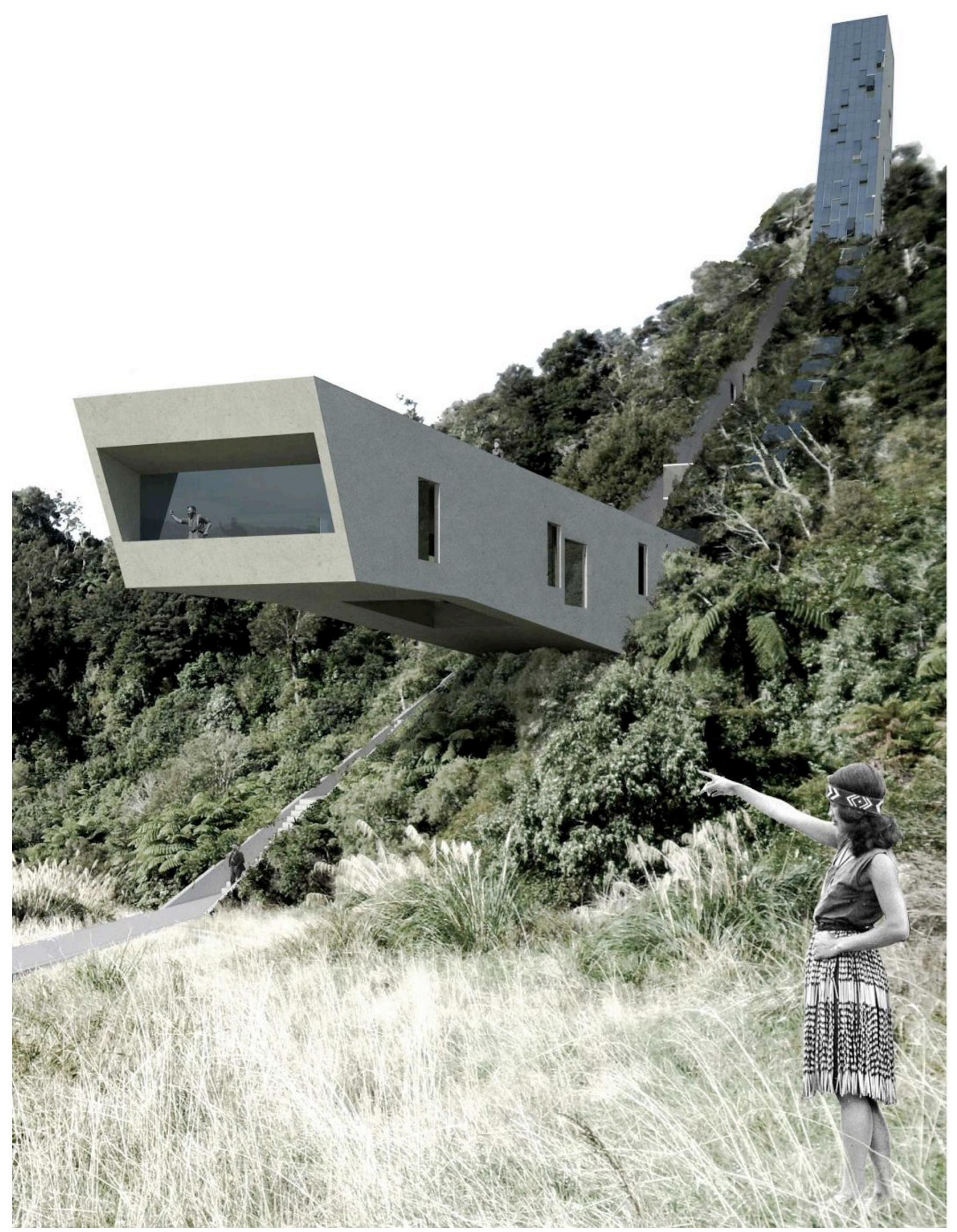




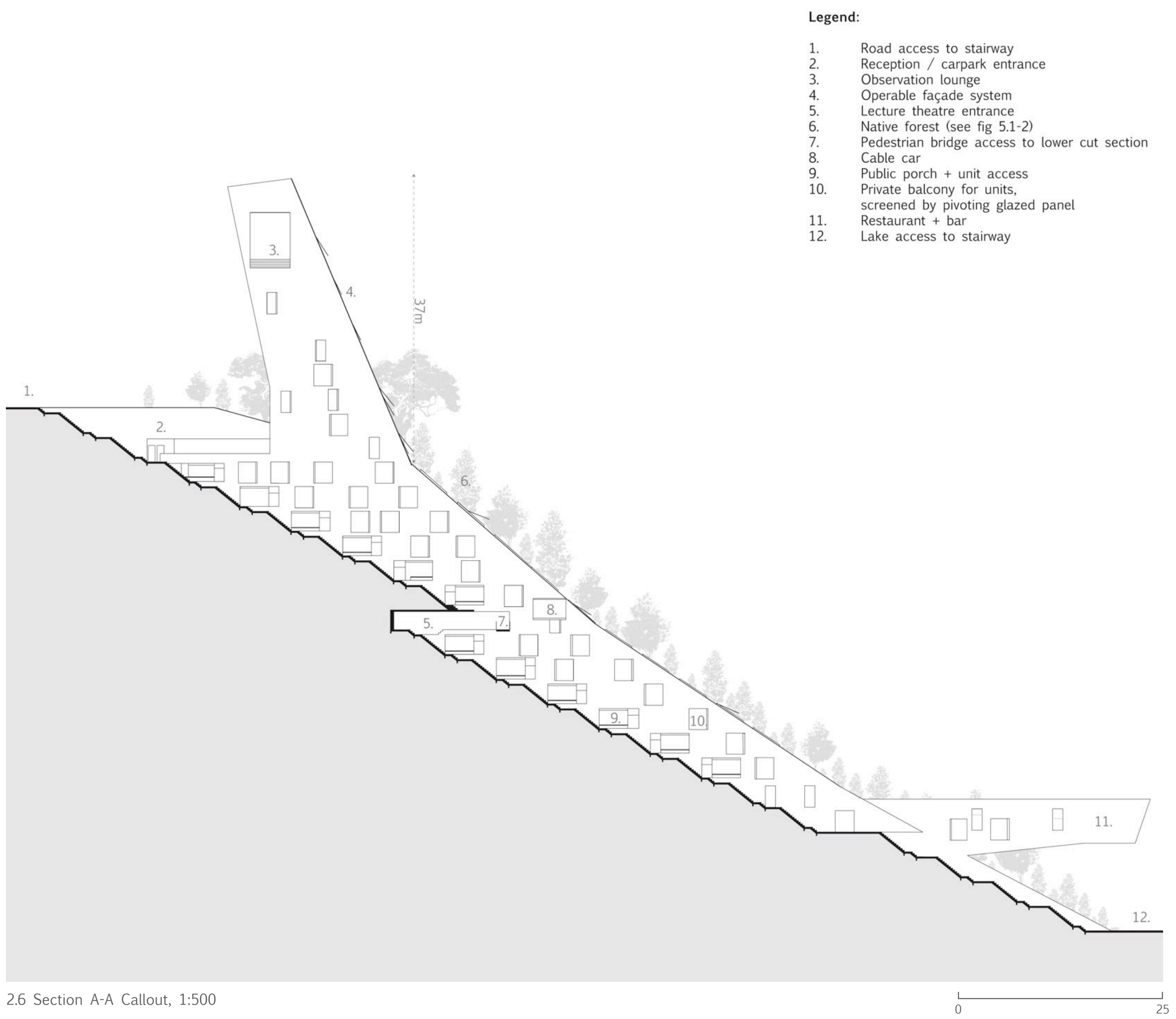




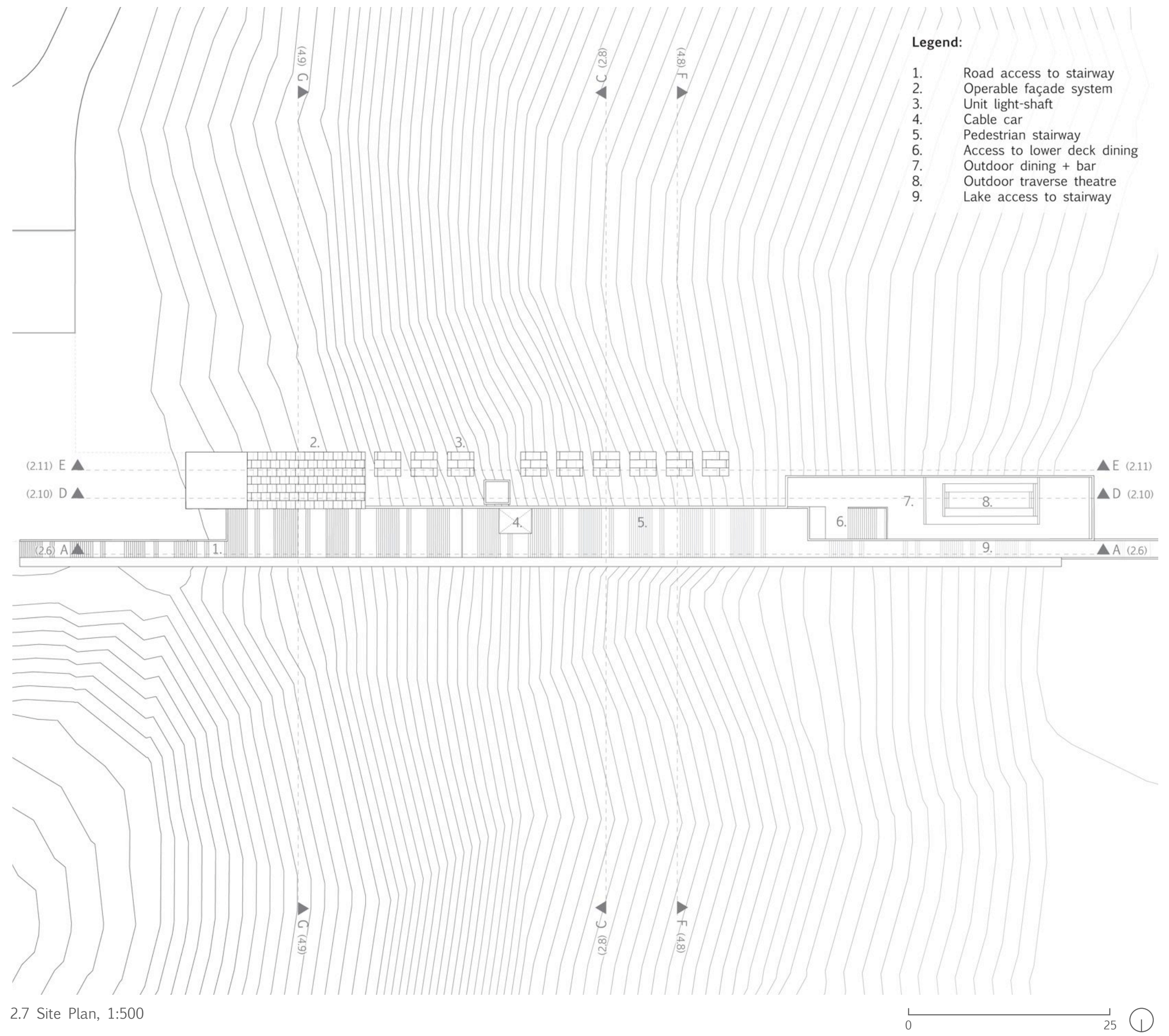




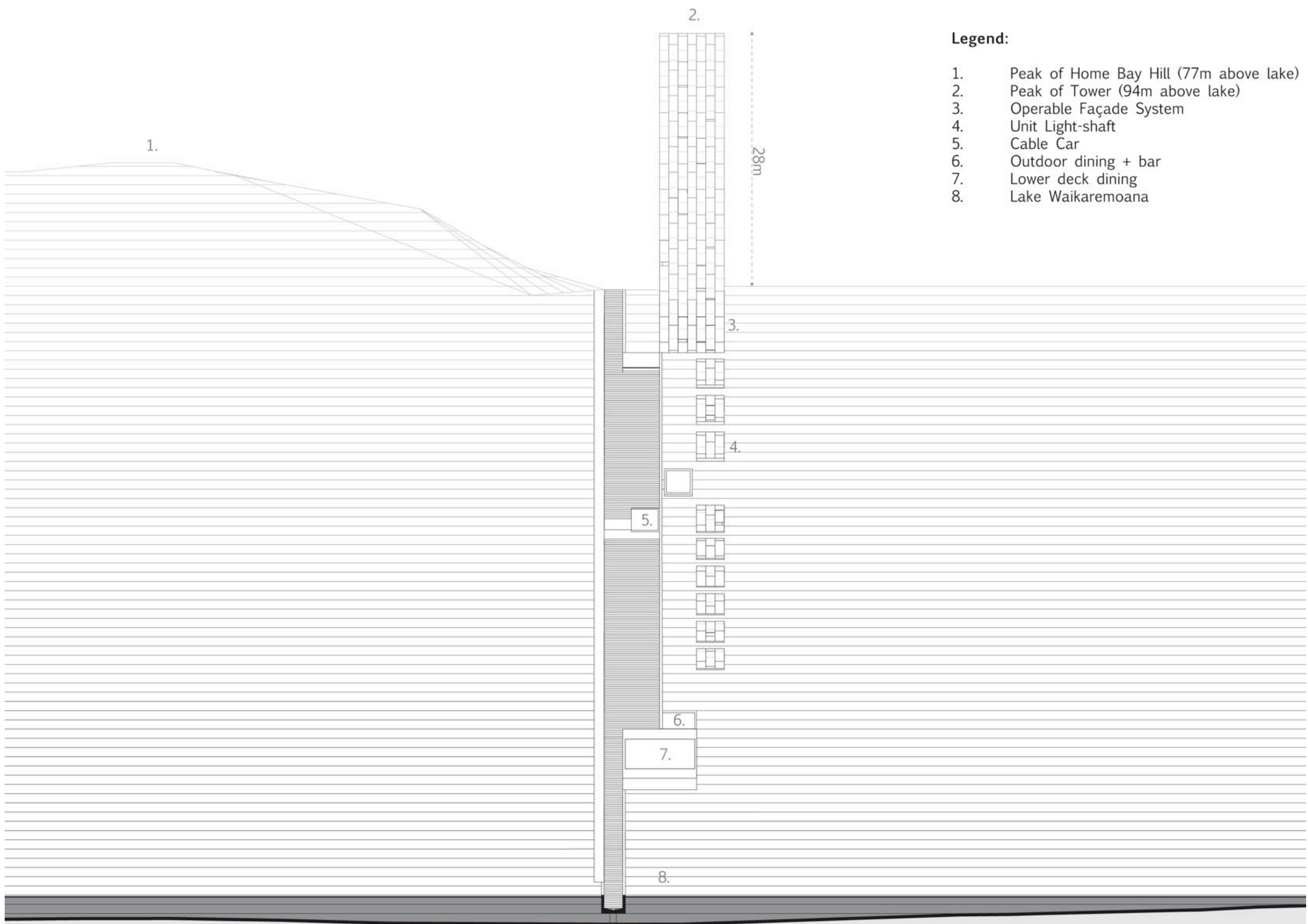




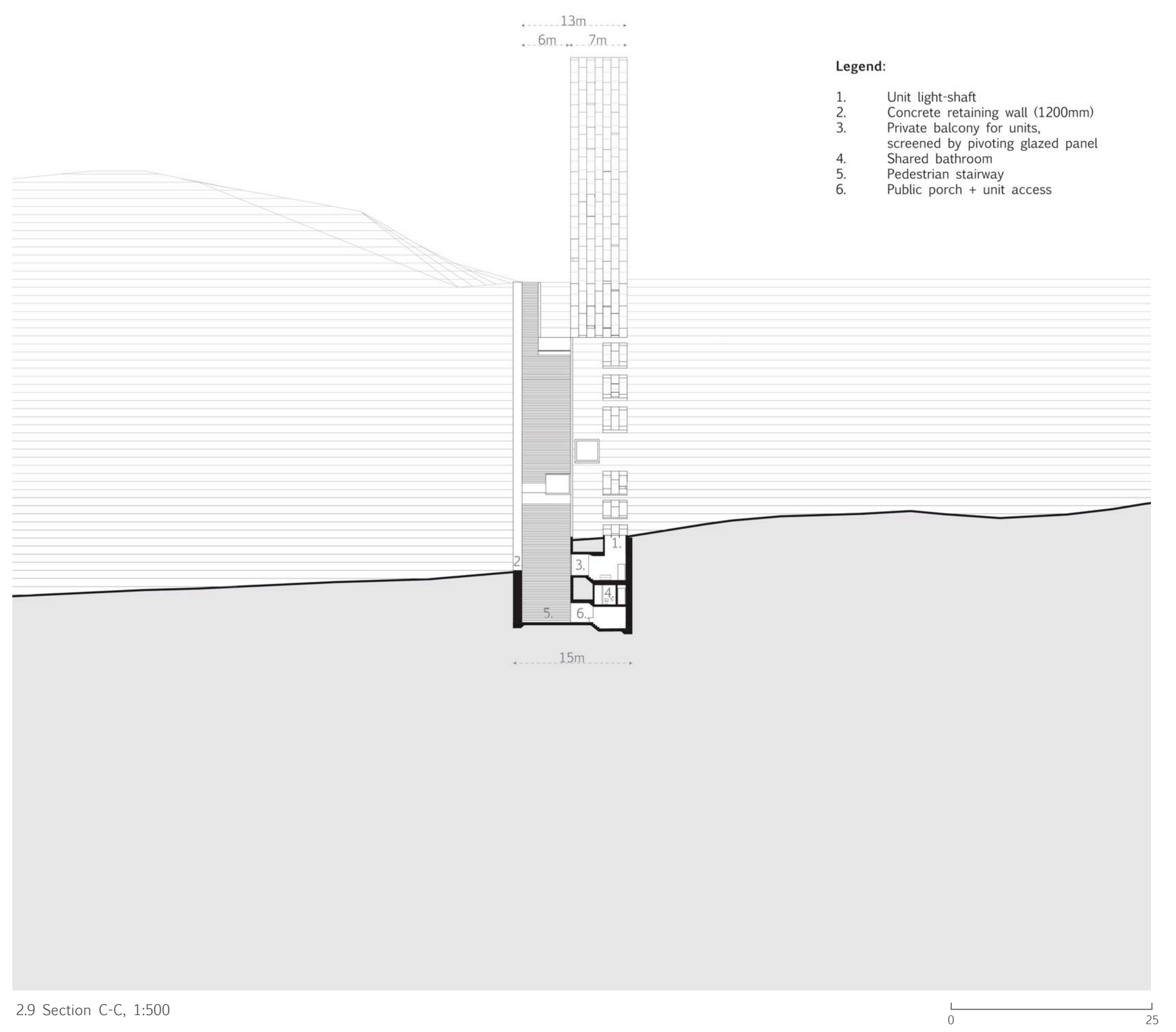




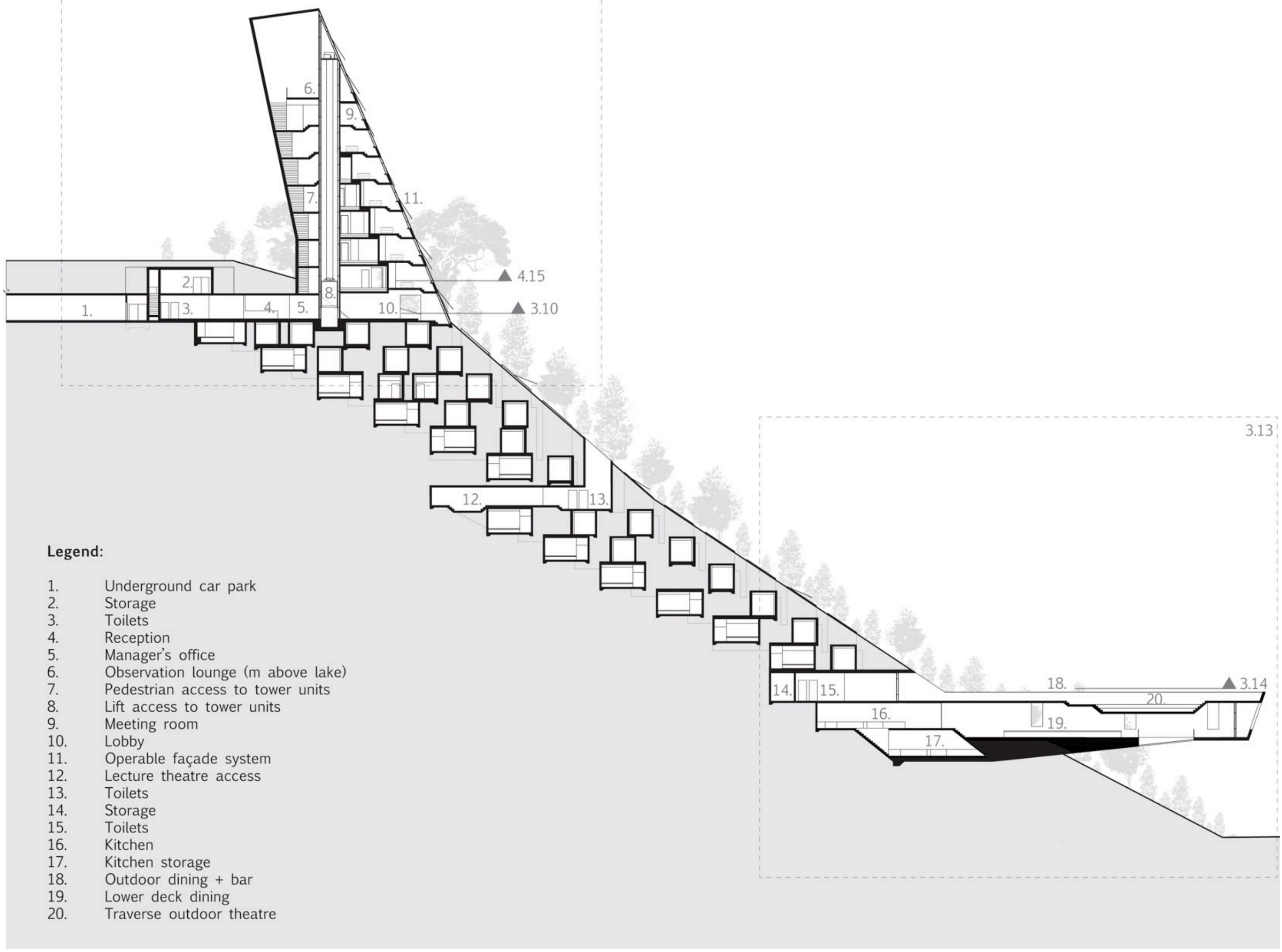




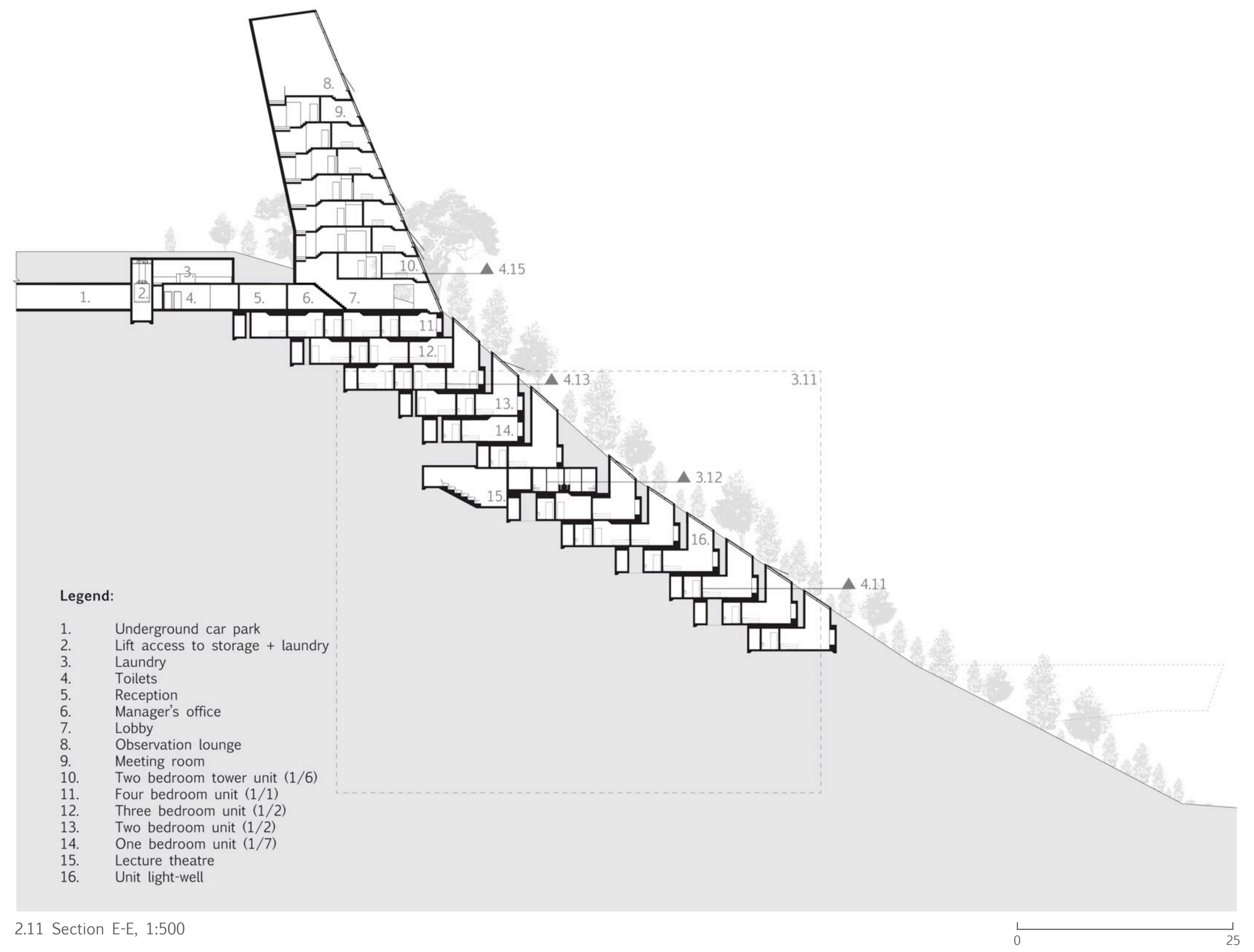




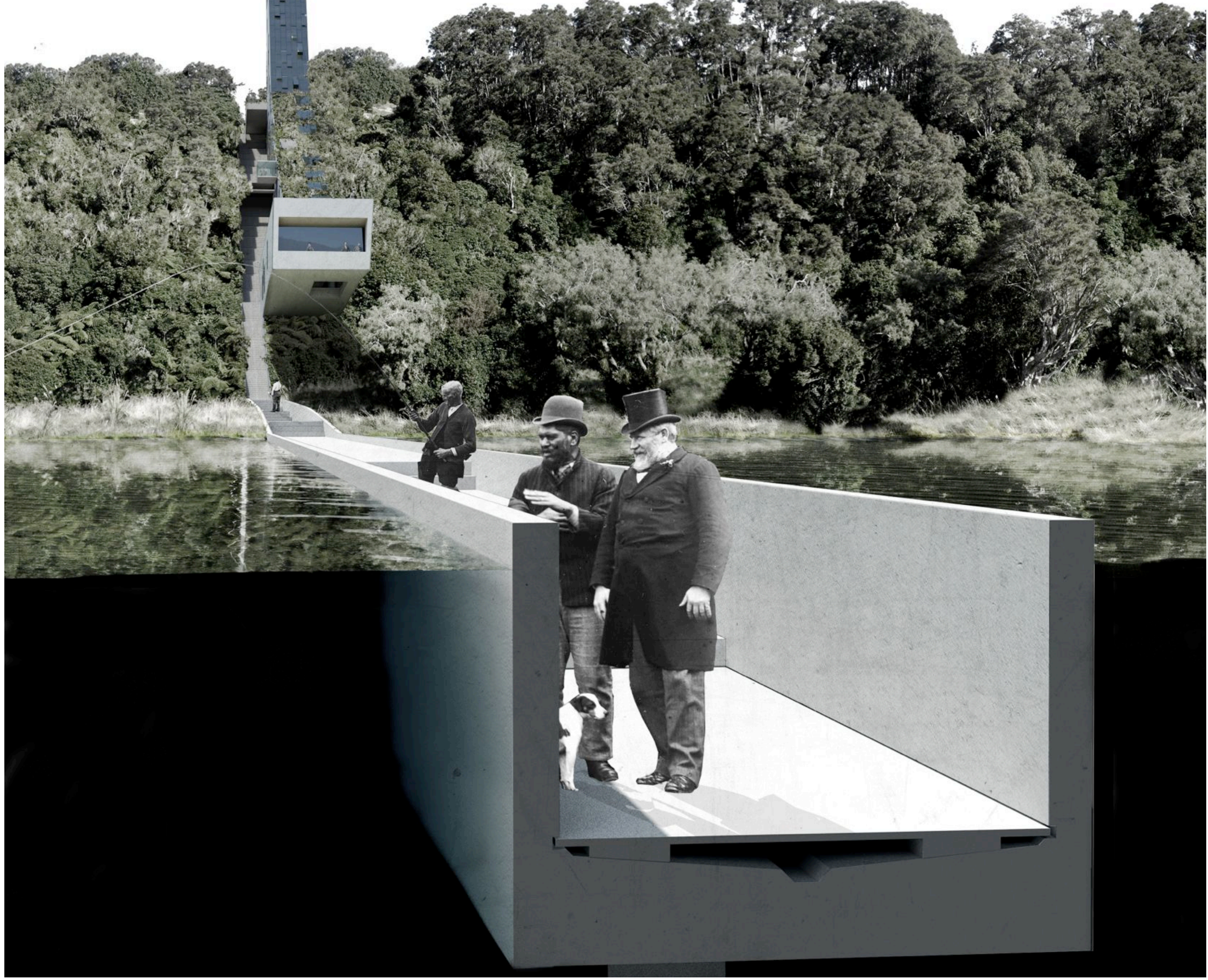




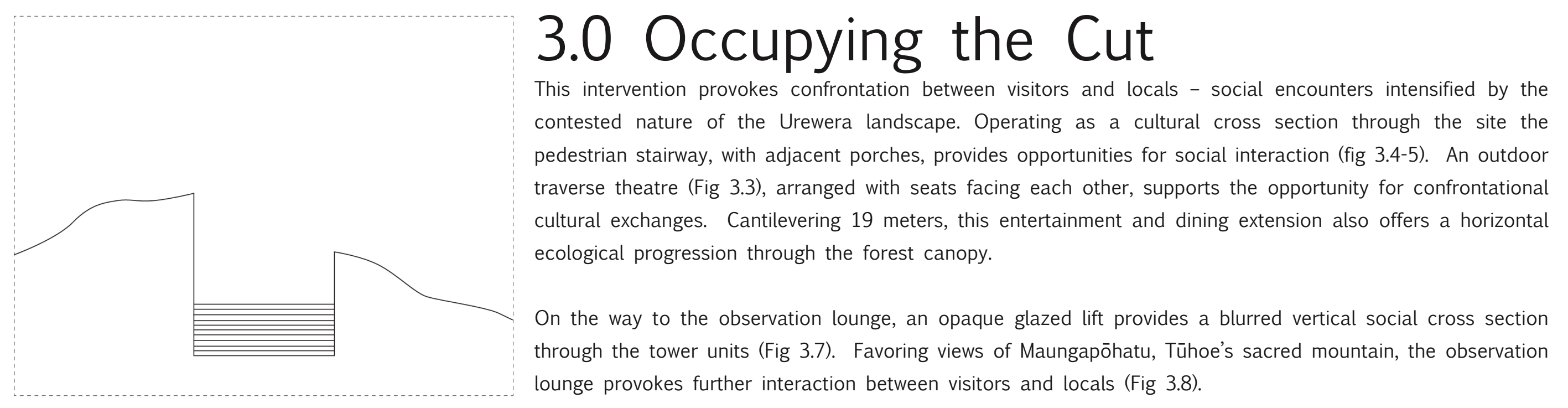

3.2 Occupying the Cut 

(1) 


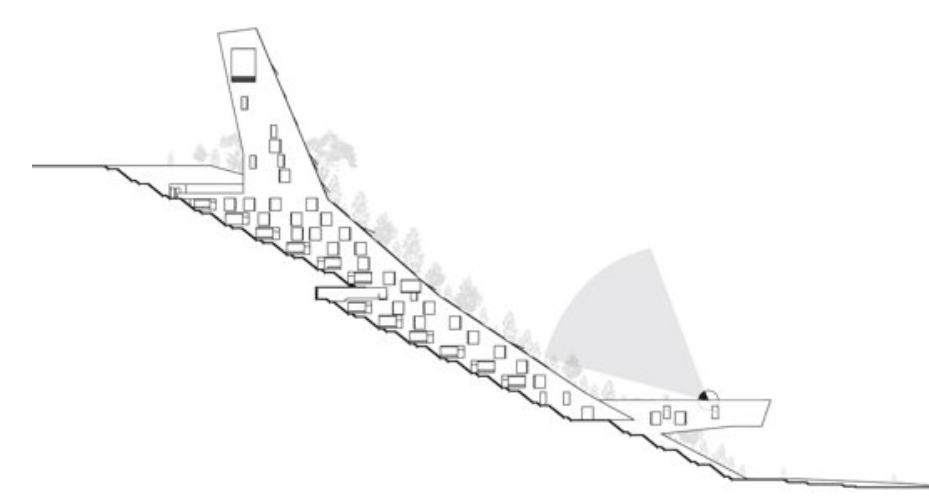

3.3 Occupying the Cut: Traverse Theatre and Outdoor Dining on Canopy Extension

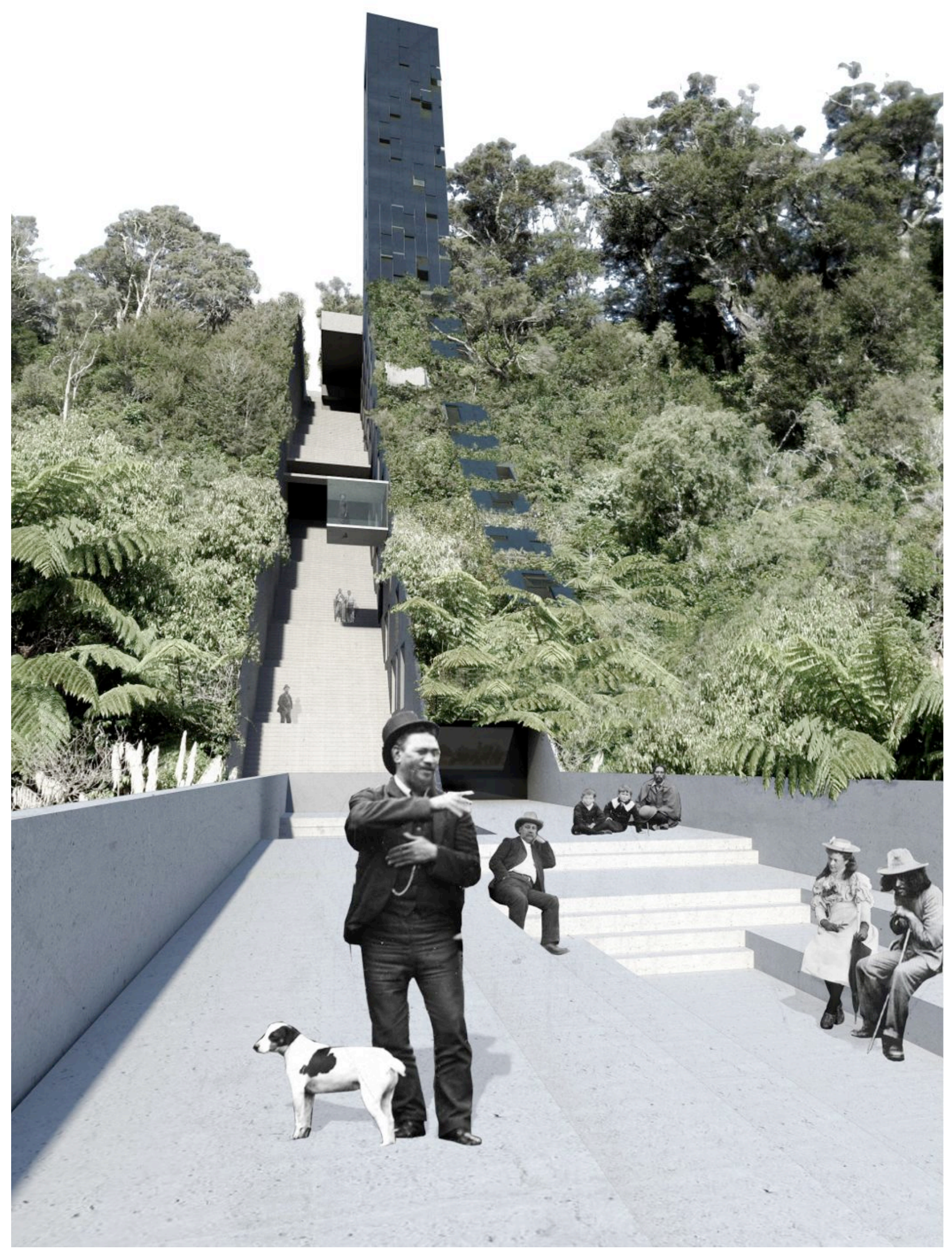




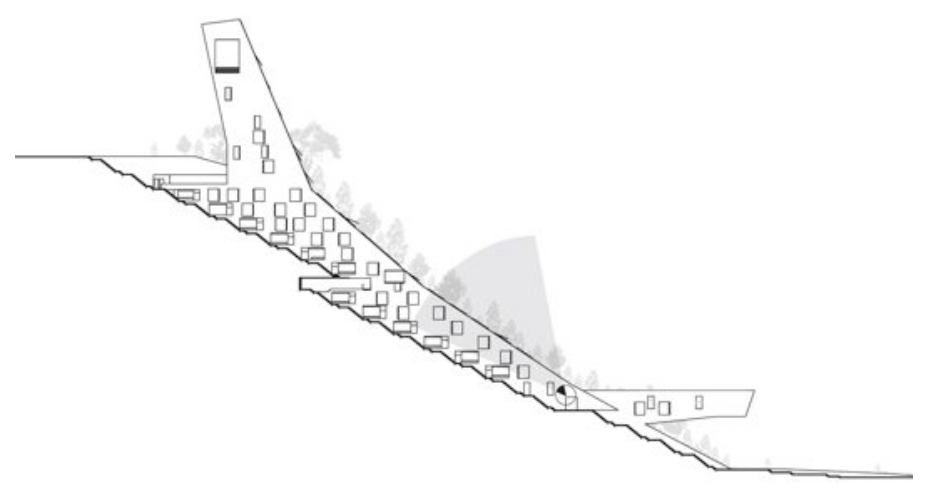

3.4 Occupying the Cut: Looking up Cut

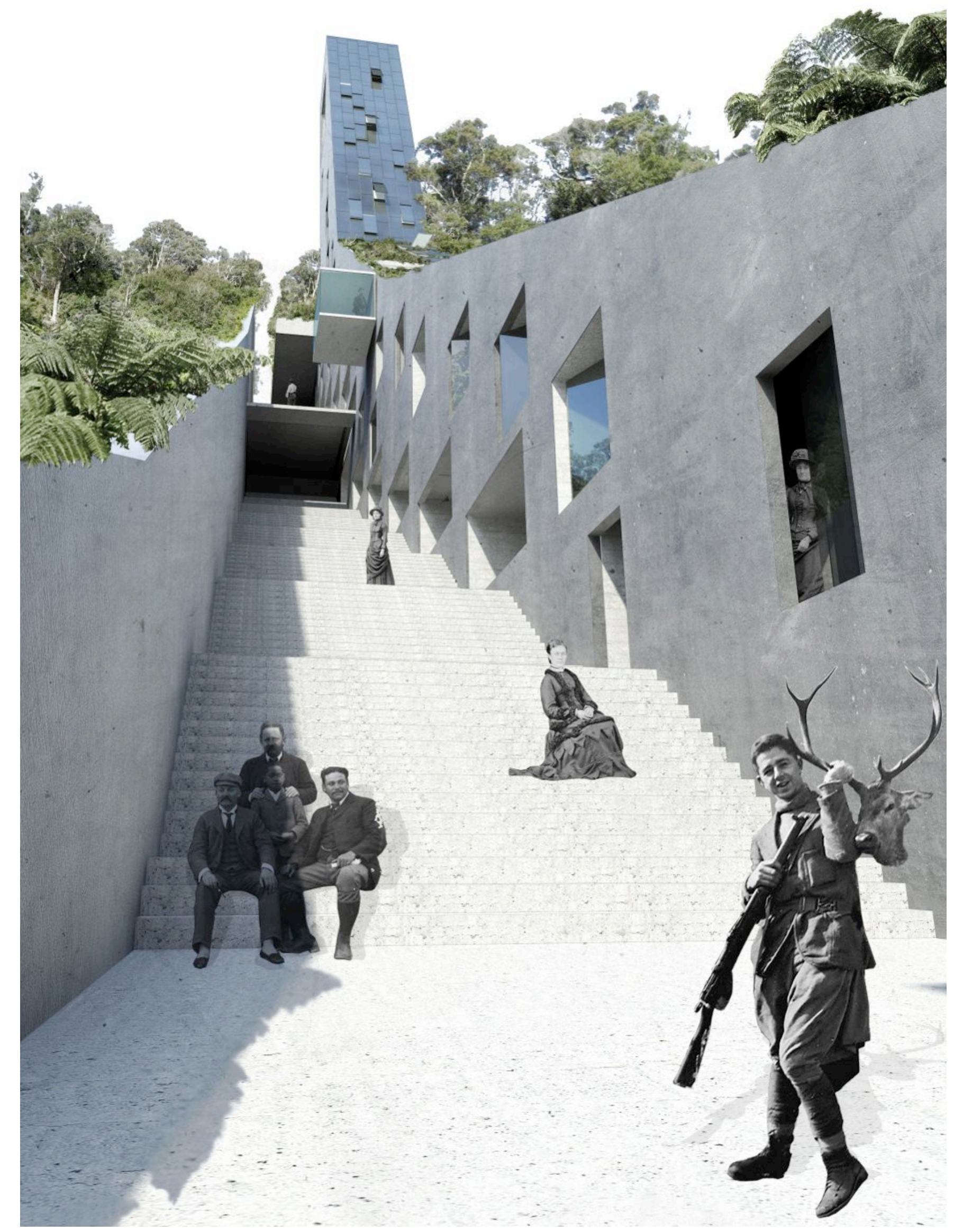




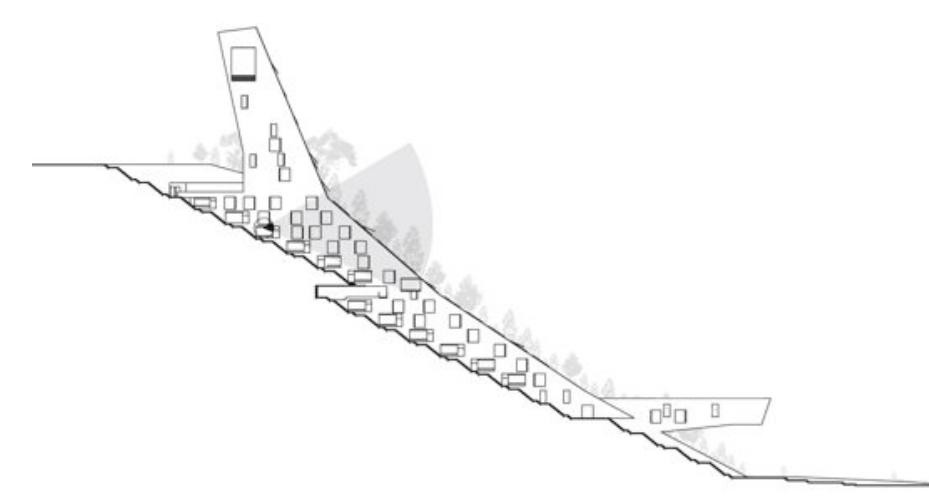

3.5 Occupying the Cut: Looking Down Cut

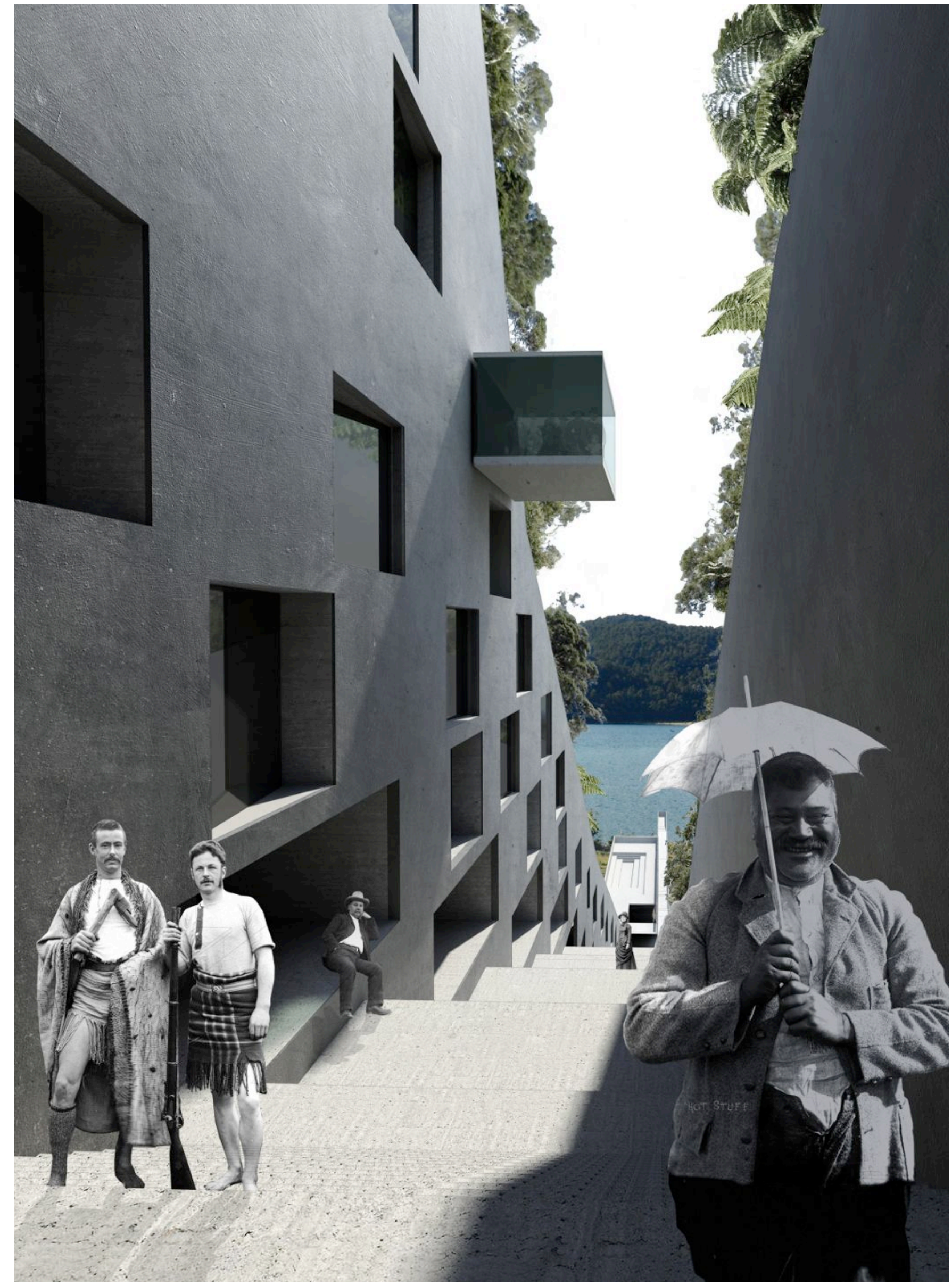




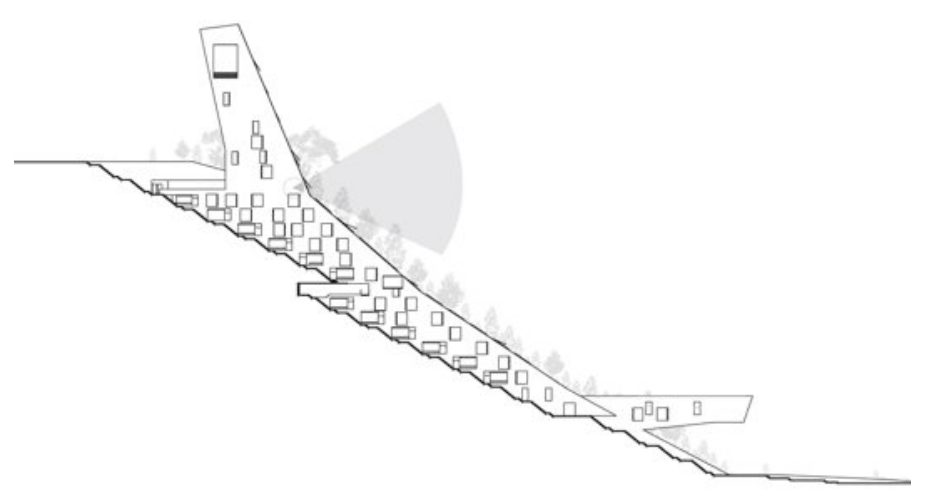

3.6 Occupying the Cut: Reception Lobby Looking Towards Panekeri Bluff

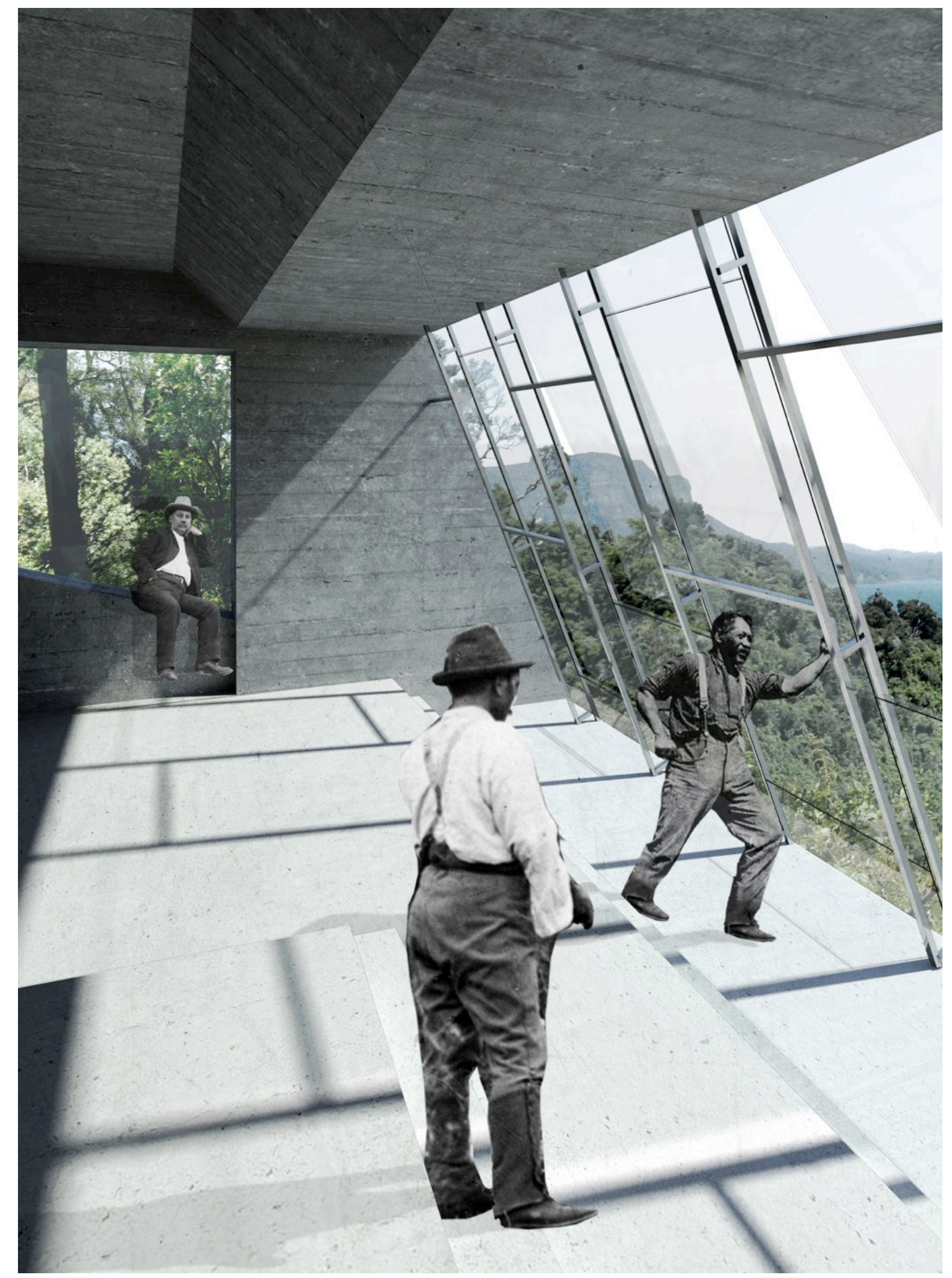

3.6 Occupying the Cut: Reception Lobby Looking Towards Panekeri Bluff 


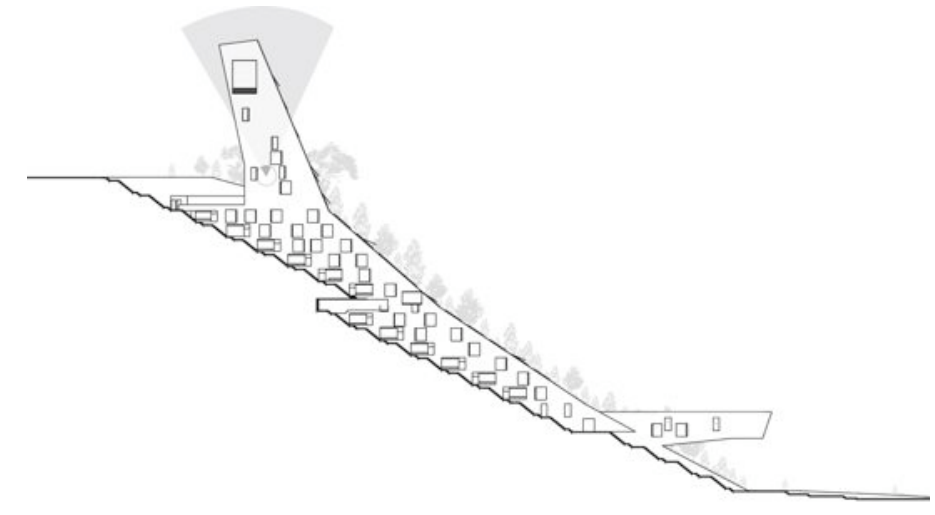

3.7 Occupying the Cut: Social Cross Section Through Lift

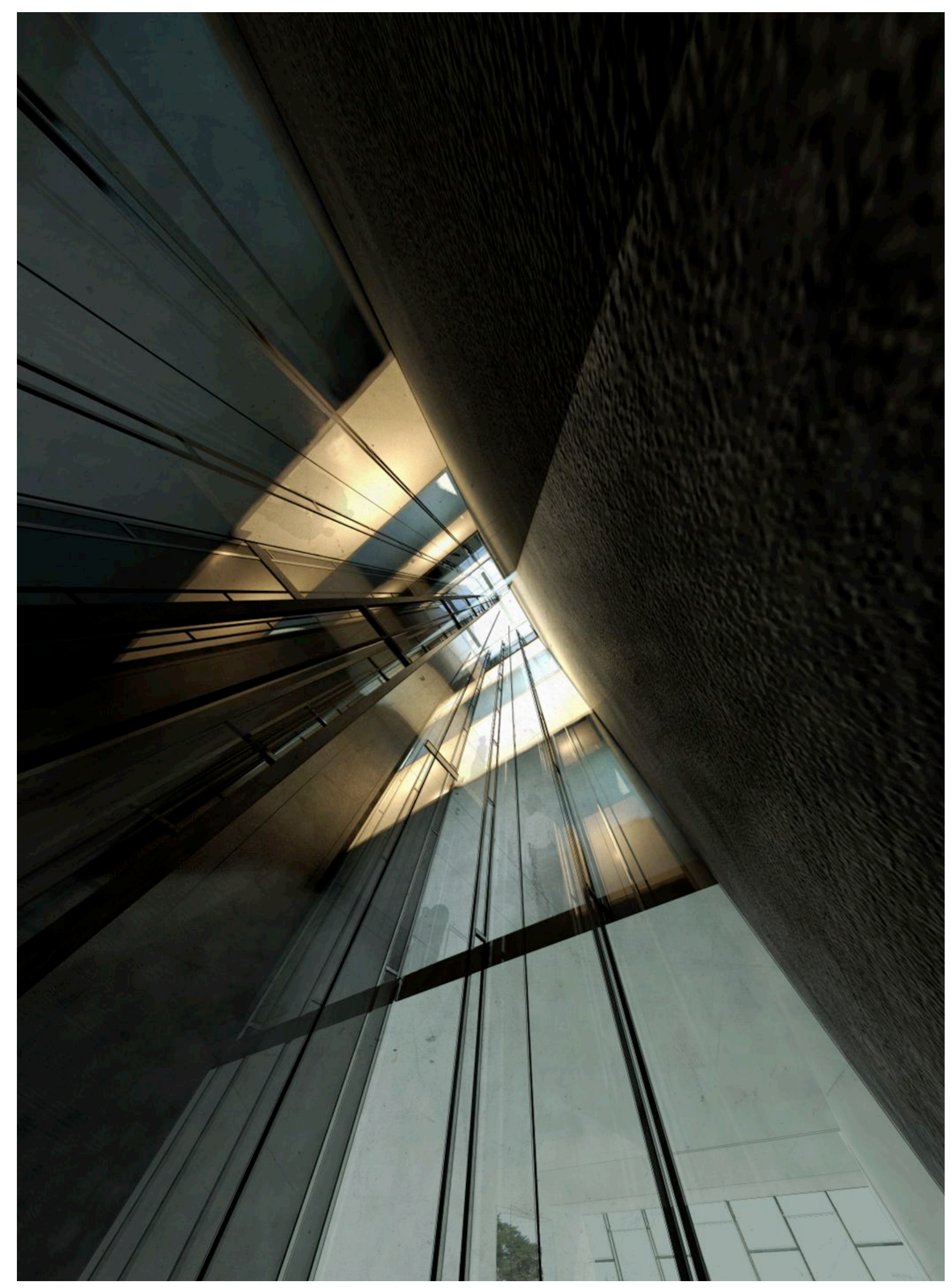




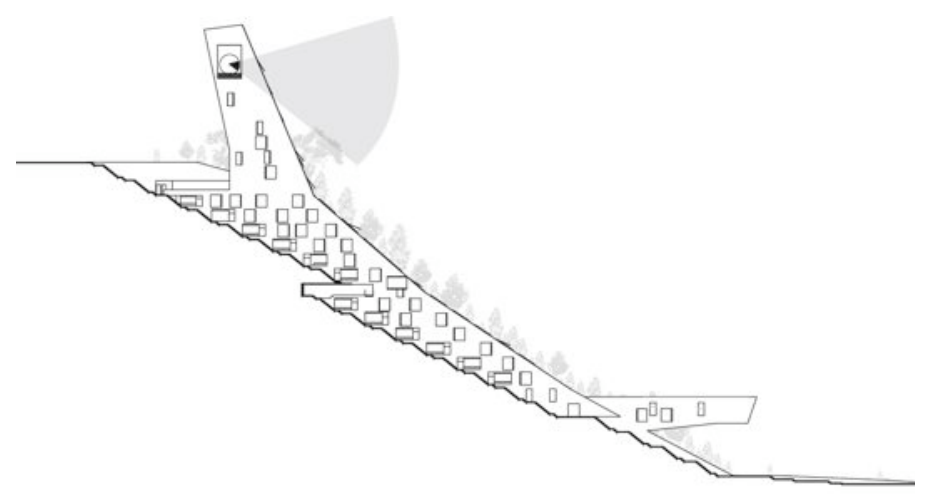

3.8 Occupying the Cut: Observation Tower Looking to Locally Significant Maungapōhatu

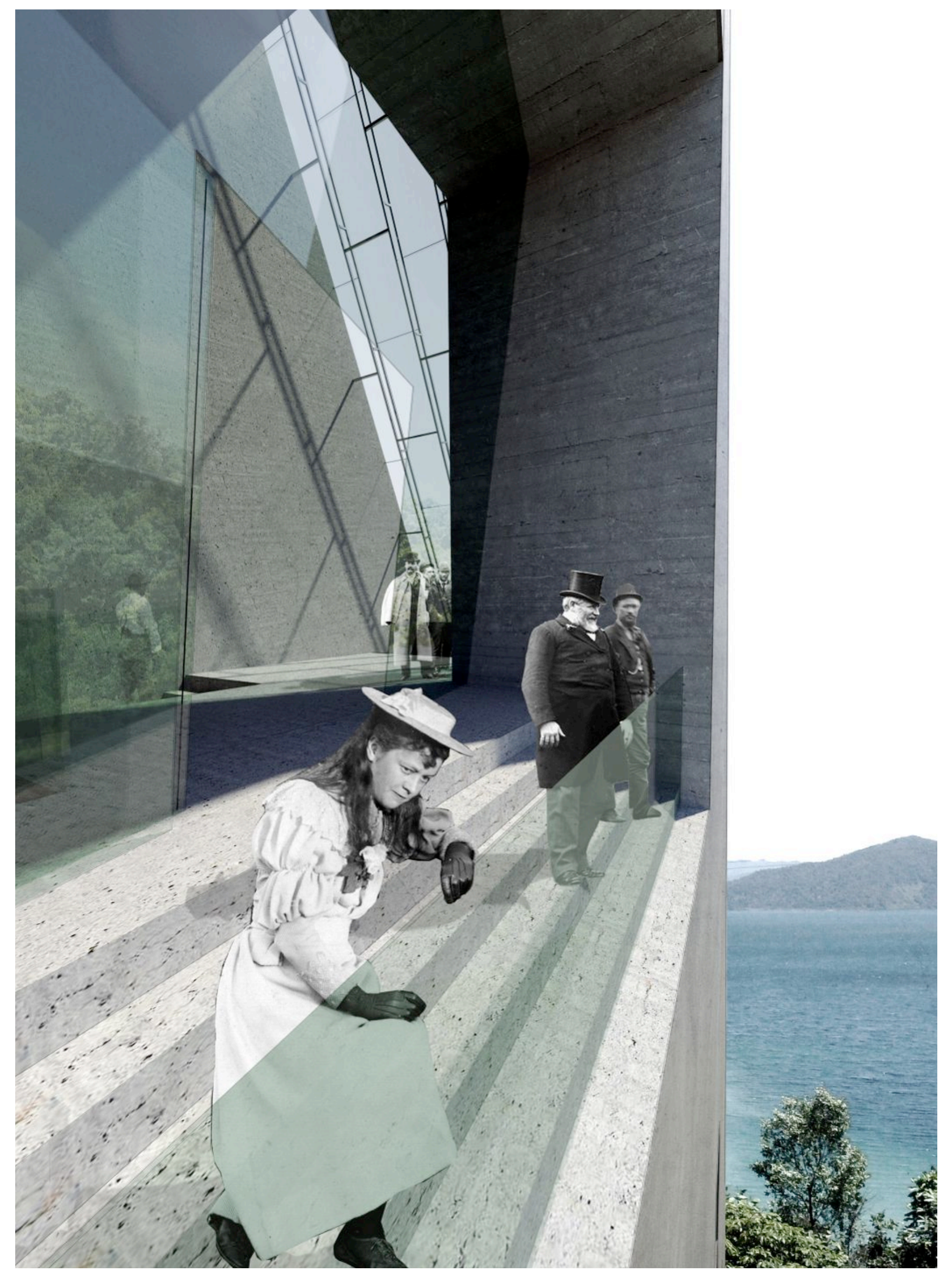


Legend:

Underground Car Park

Storage

Toilets

Reception

Manager's office

Observation lounge

Pedestrian access to tower units

Lift access to tower units

Meeting room

Lobby

Two bedroom tower unit $(1 / 6)$

Operable façade system

Four bedroom unit $(1 / 1)$

Three bedroom unit $(1 / 2)$
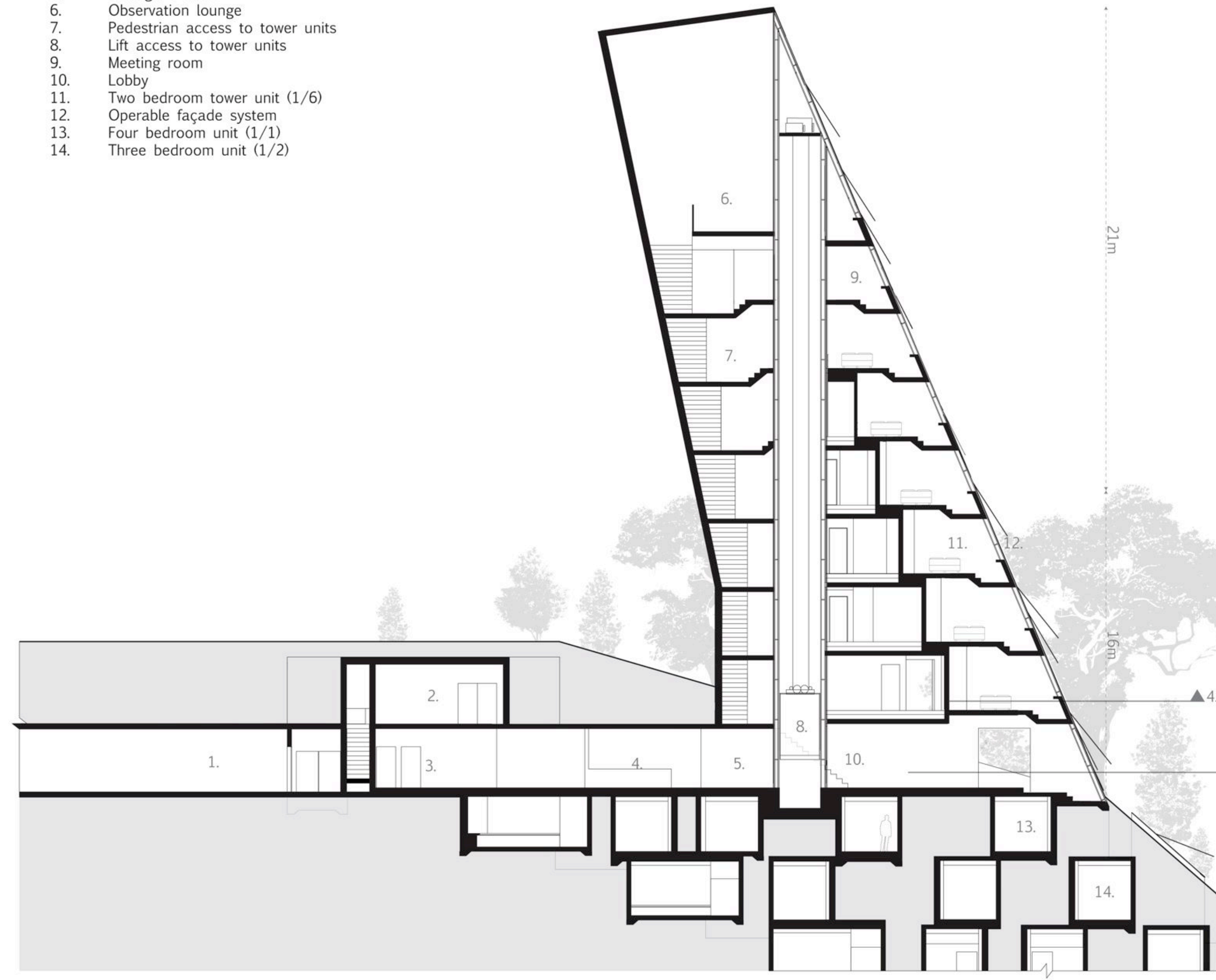
1. Underground car park

Pedestrian access to road

Access to laundry + storage

Reception

Managers office

Lift access to tower units

Pedestrian access to

tower units

Cable car

Lobby

Operable façade system

Unit light-shaft

Pedestrian access to lake

(3.9) D $\boldsymbol{\Delta}$

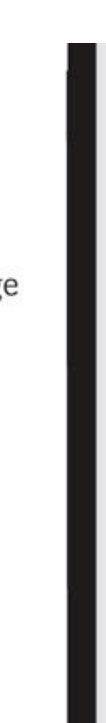

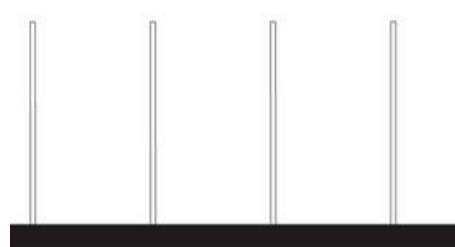

1.

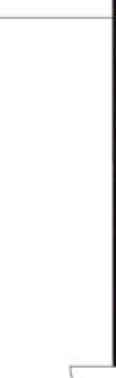

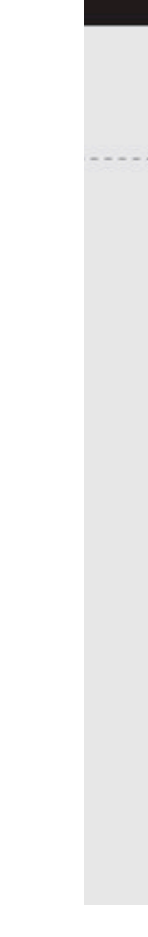

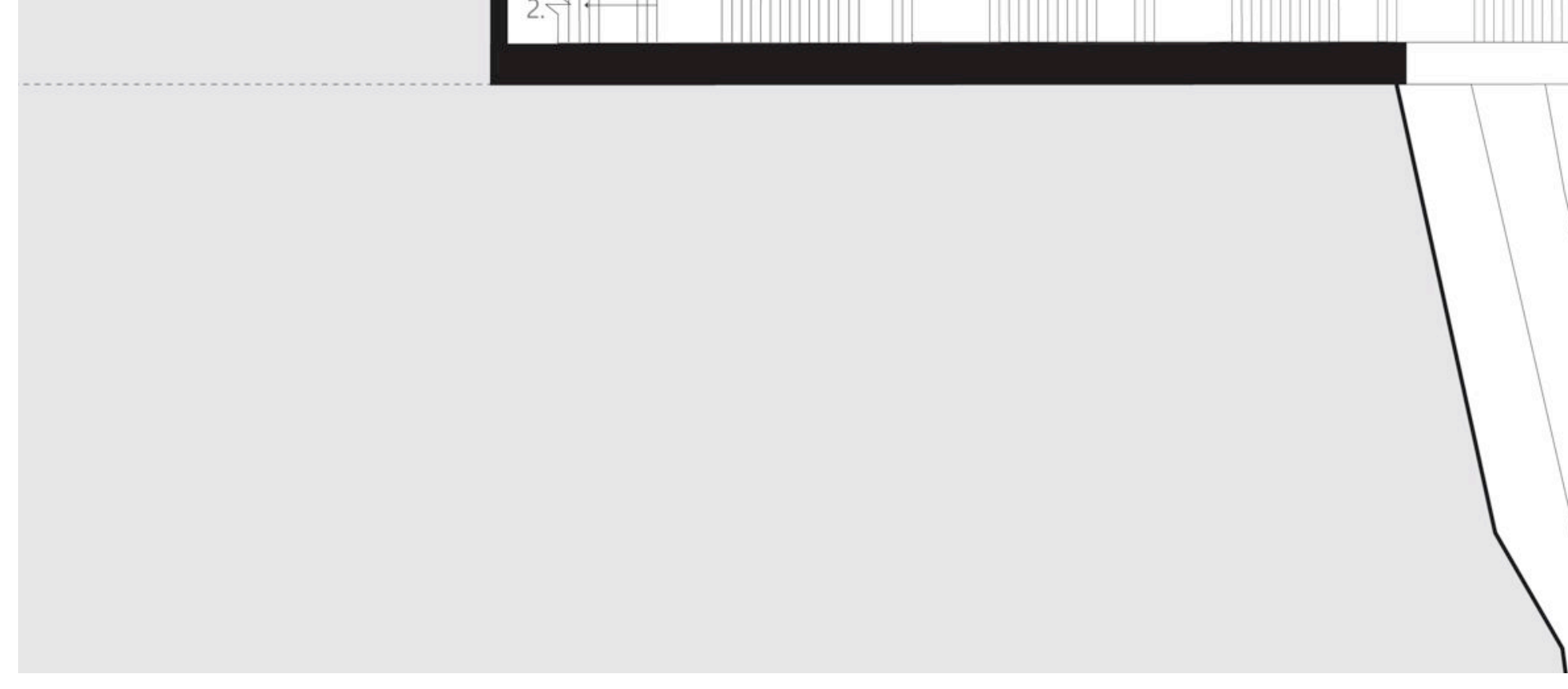




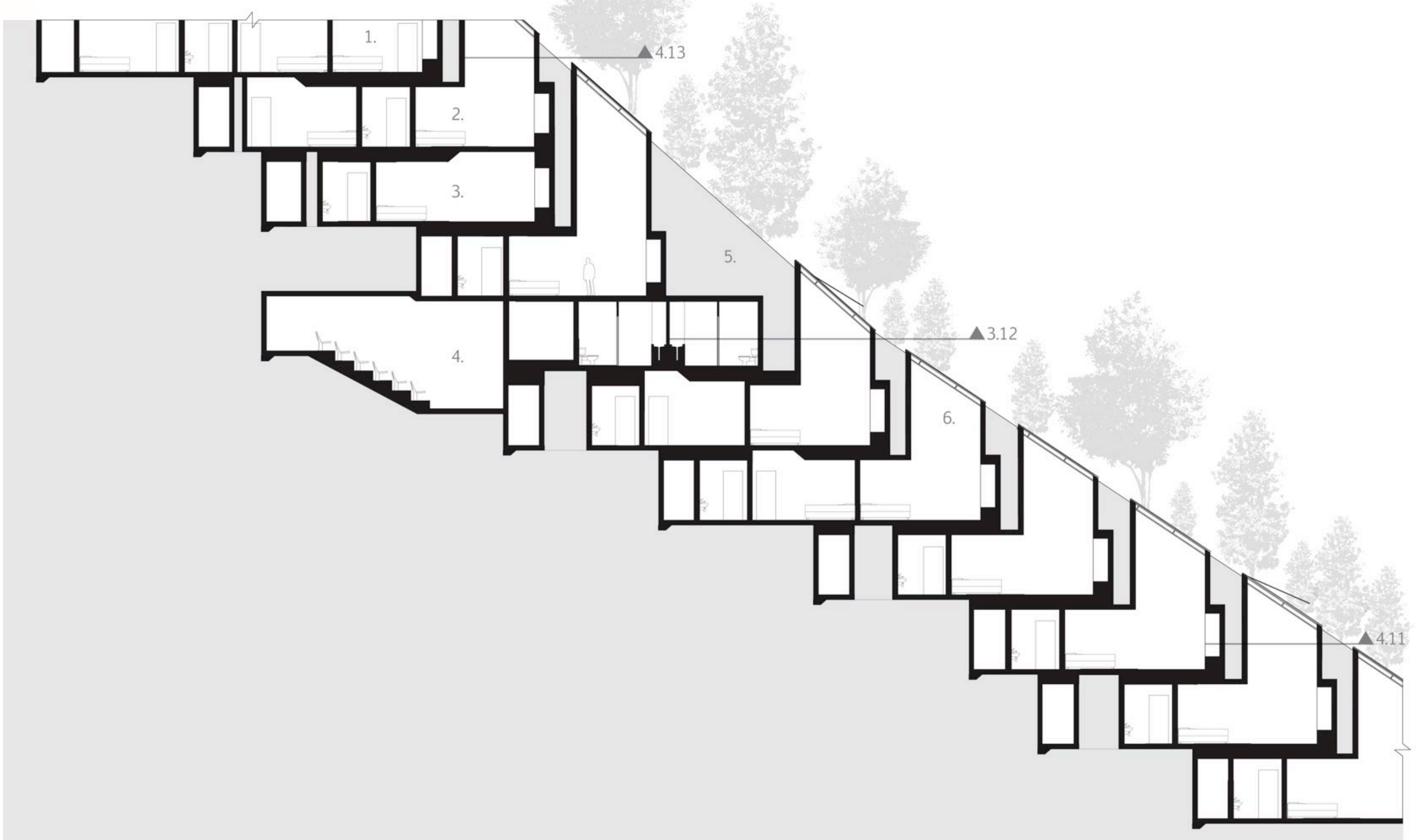

Legend:

Three bedroom unit $(1 / 2)$

Two bedroom unit $(1 / 2)$

One bedroom unit $(1 / 7)$

Lecture theatre

Deep soil pockets for forest growth

Unit light-shaft 


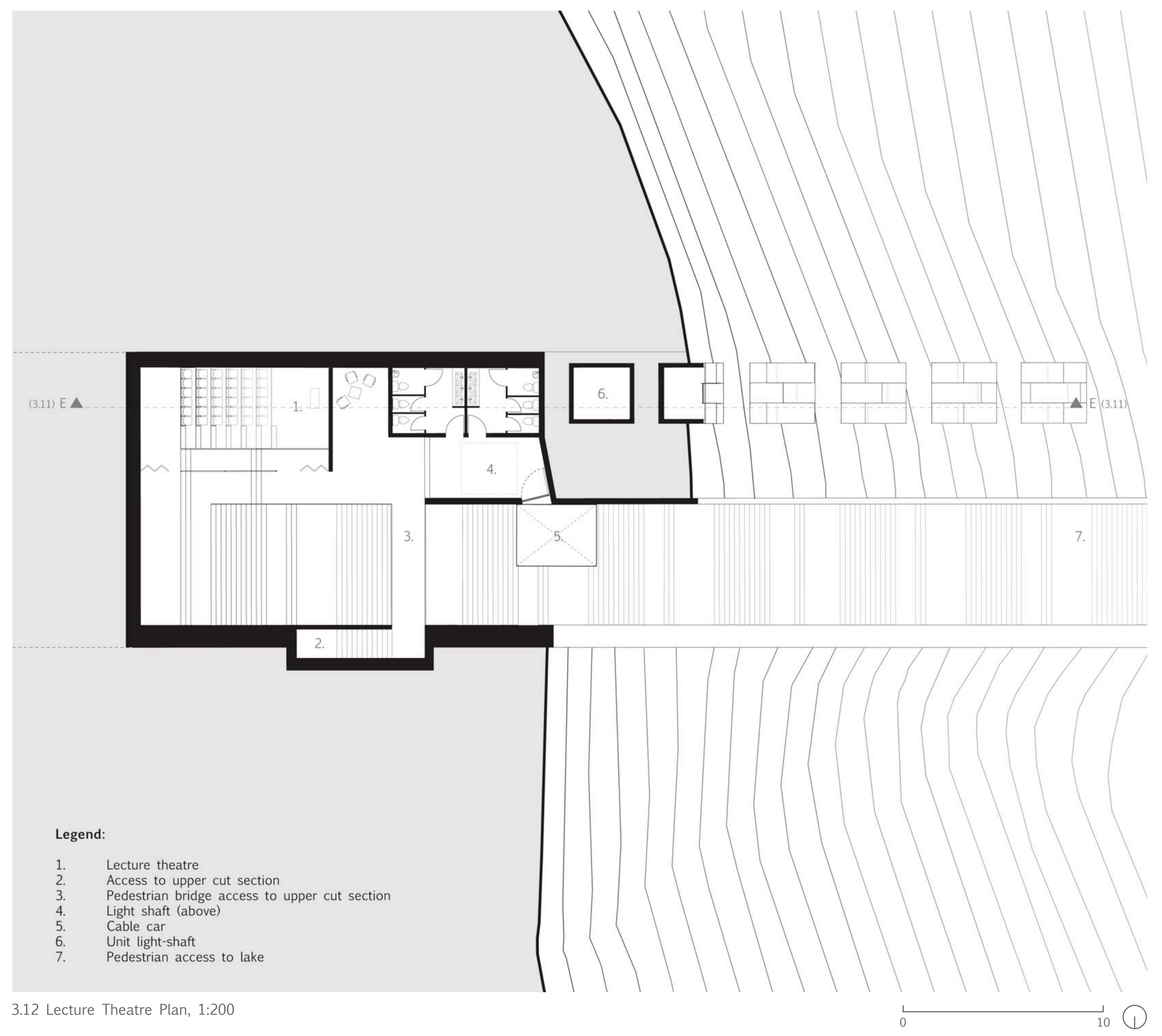




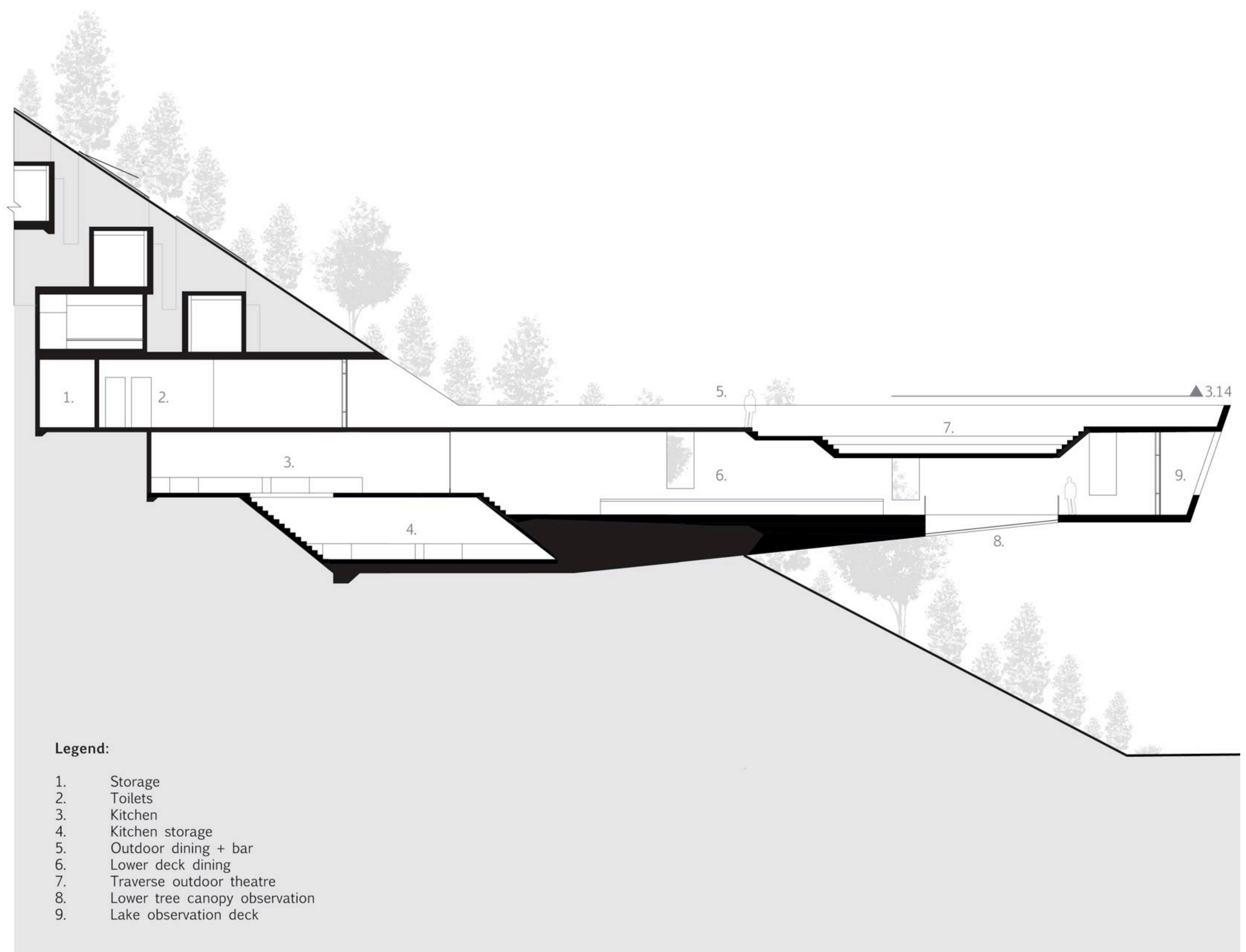




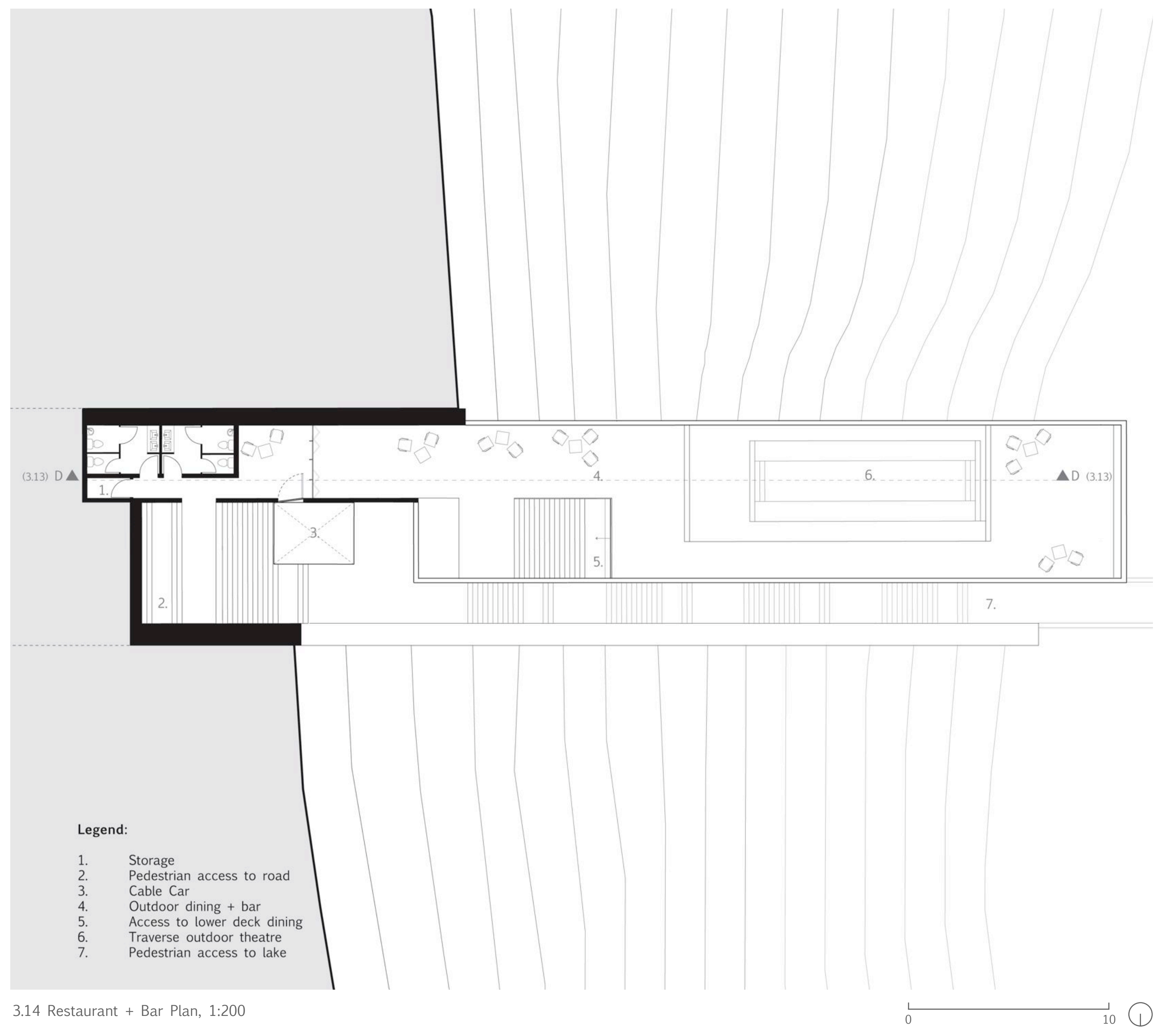




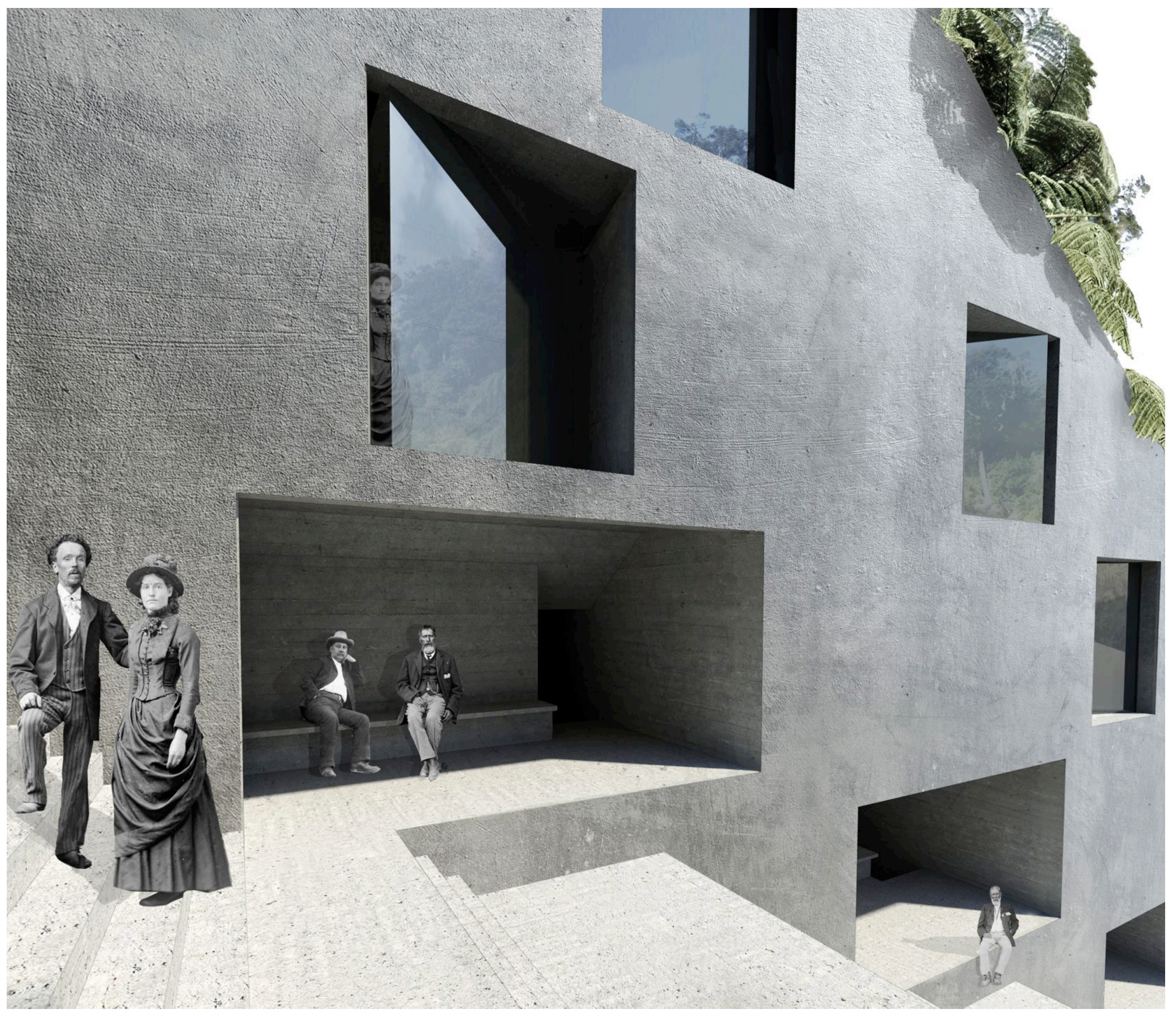




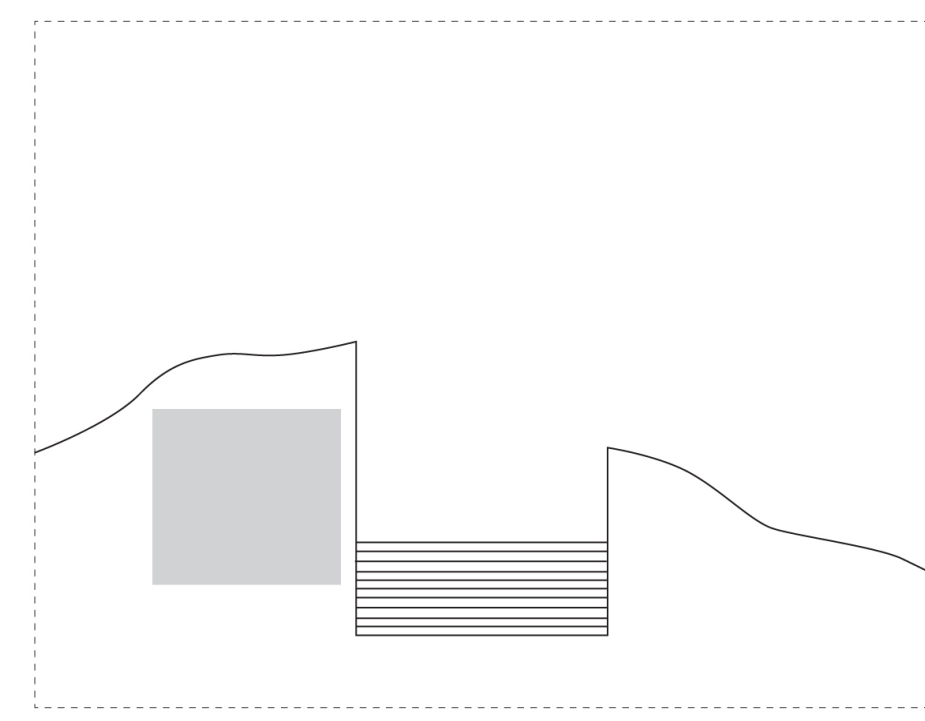

4.2 Occupying the Resort

\subsection{Occupying the Resort}

Physically bunkering into the landscape the cut provides refuge both from and within the natural environment. The intervention supports 68 inhabitants and additional day-visitors in the restaurant, observation tower and stairway circulation. Responding to seasonal visitor fluctuations (Fig 1.8) units have been designed to house both locals or visitors, with 3-4 bedroom units (typically housing staff + locals) located closest to the road and one bedroom units positioned near the lake and visitor facilities. Stacking the units along the Northfacing facade achieves density requirements (Fig 5.3-5) and ensures inhabitants remain visually connected to the landscape. Public porches and private balconies along the cut encourage an active social condition for passing pedestrians (Fig 4.5). Navigating the boundary between built form and landscape, pivoting glass panels provide privacy to the units (Fig 4.1) while reflecting fragmented views of the landscape into the cut. 

. . .

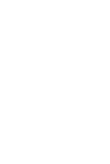

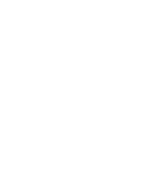
.

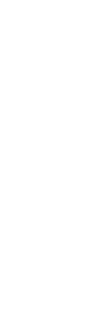

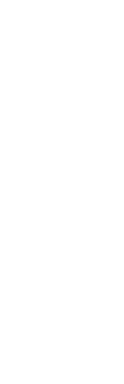

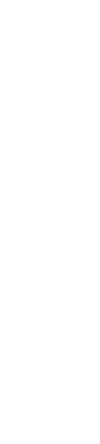

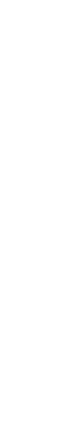

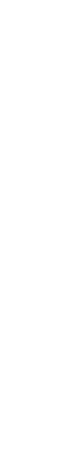

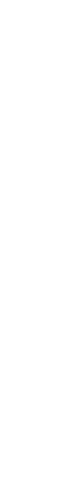

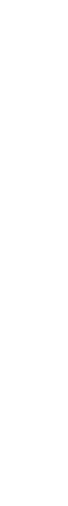

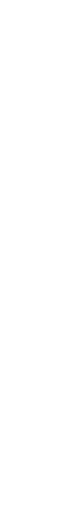

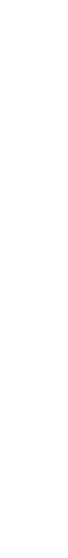

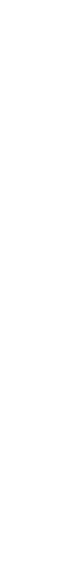

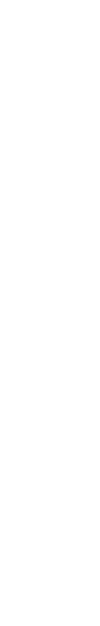
列 . 列 . 


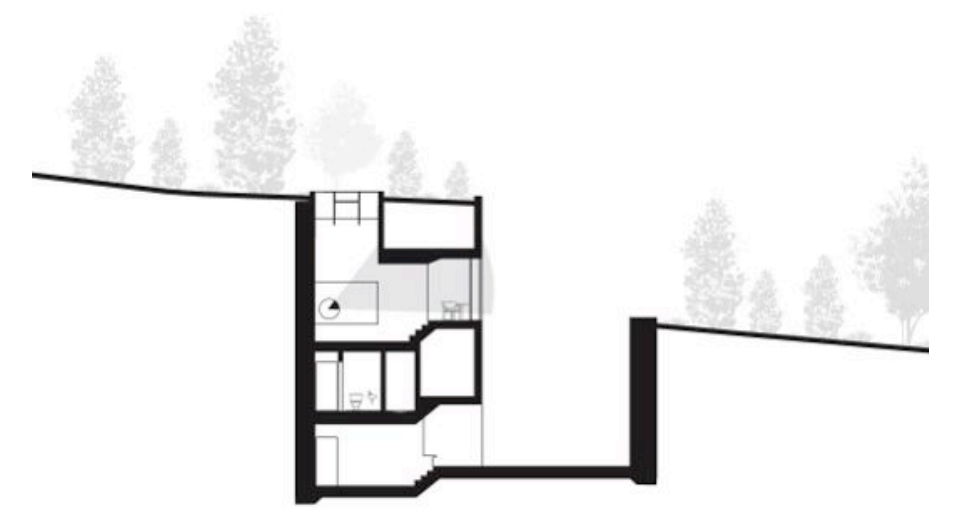

4.3 Occupying the Resort: Executive Suite (Unit 4.11): Master Bedroom

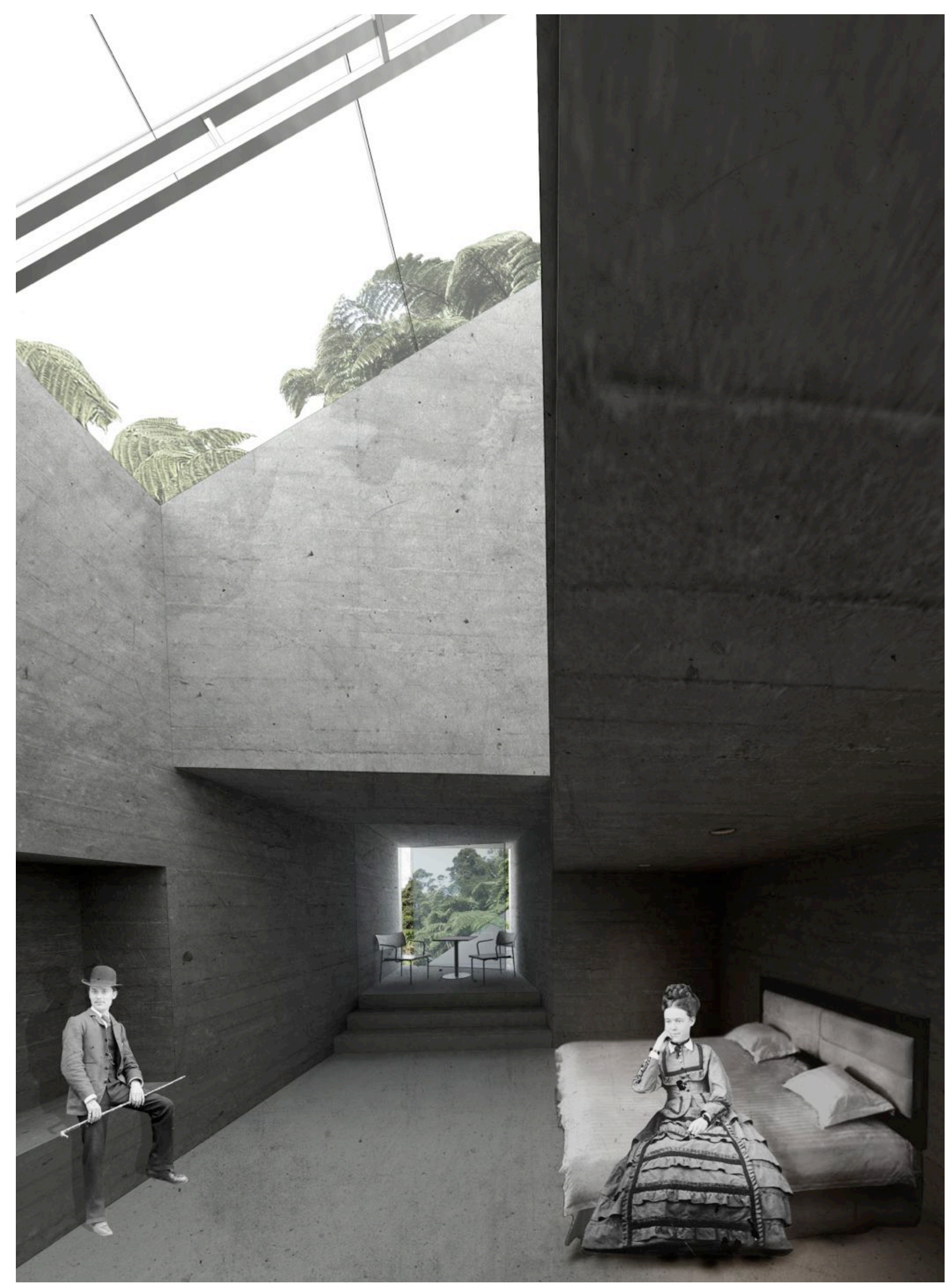




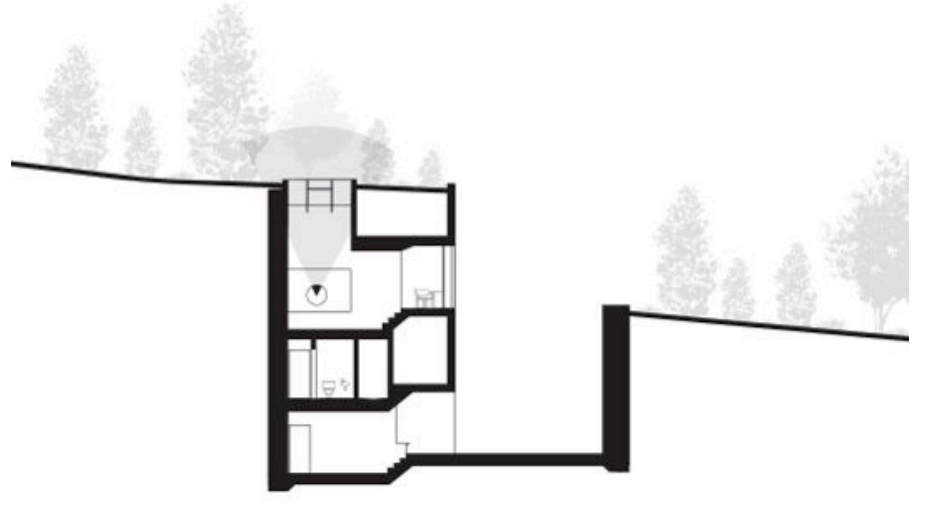

4.4 Occupying the Resort: Executive Suite (Unit 4.11): Looking up Light-shaft

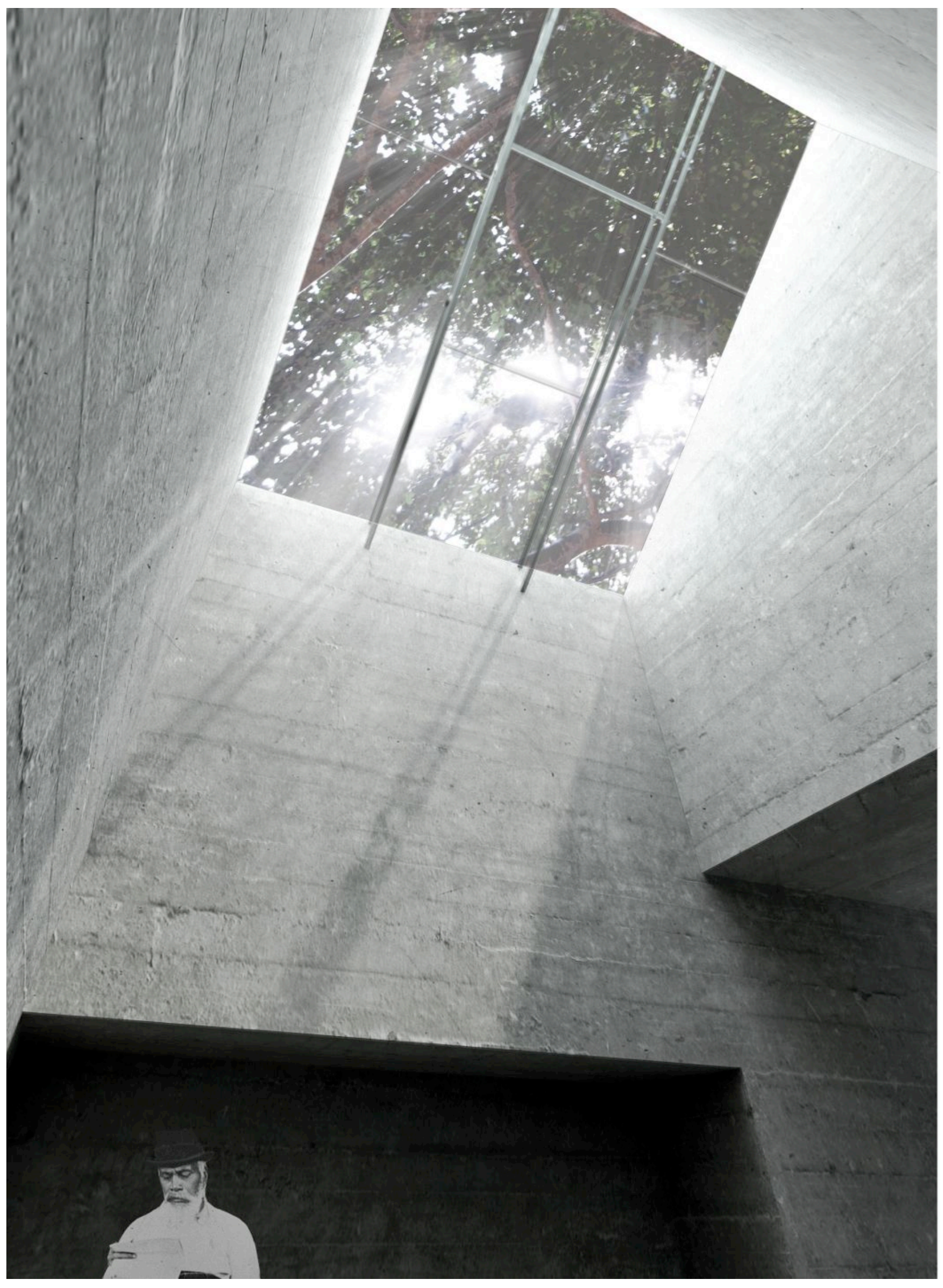




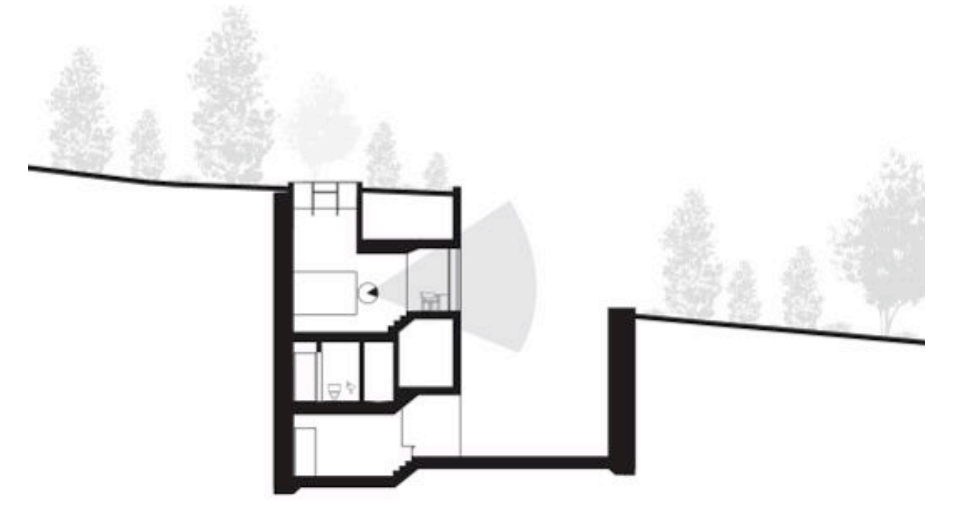

4.5 Occupying the Resort: Executive Suite (Unit 4.11): Looking Through Pivoting Panel Towards Bush

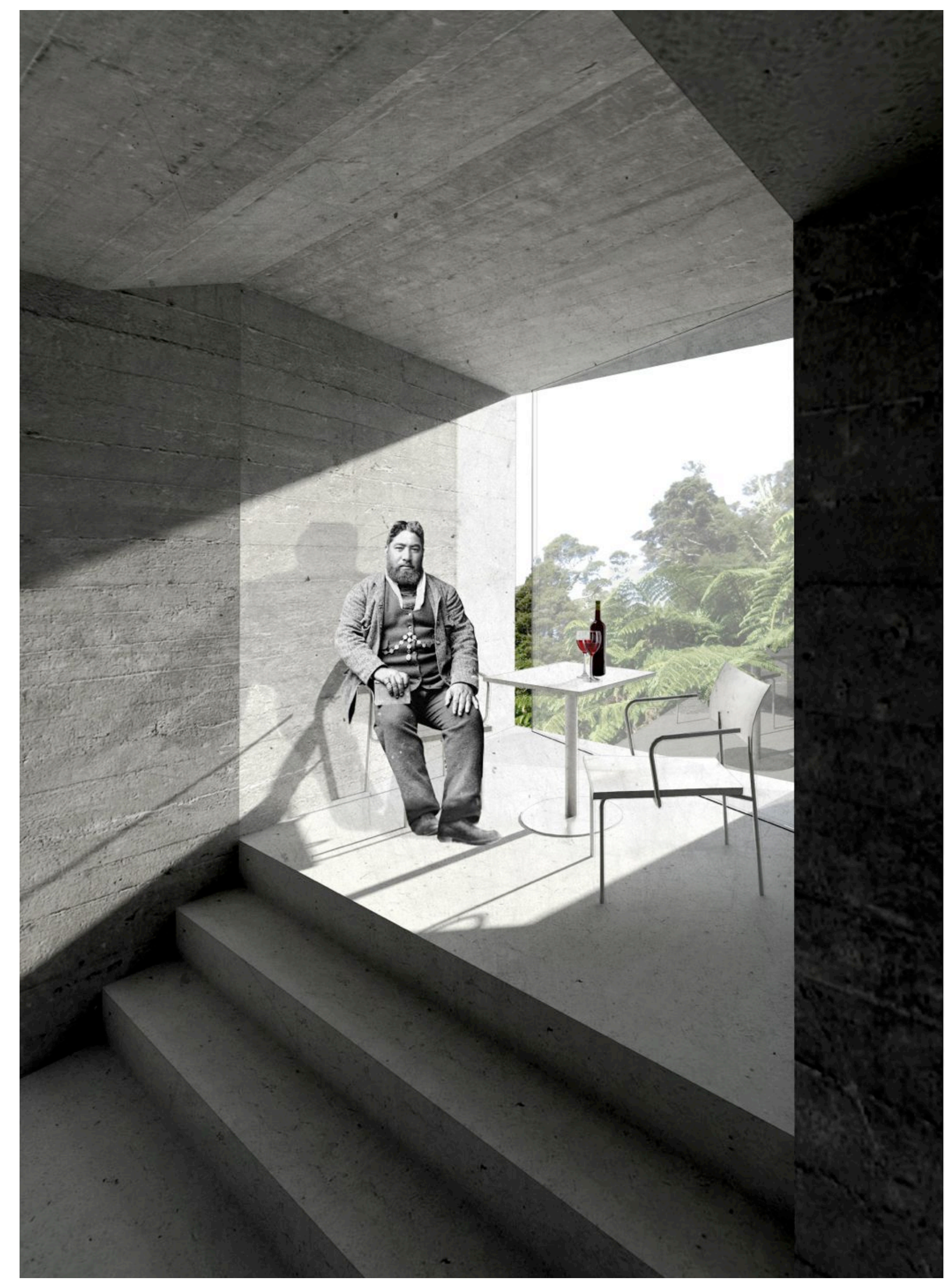




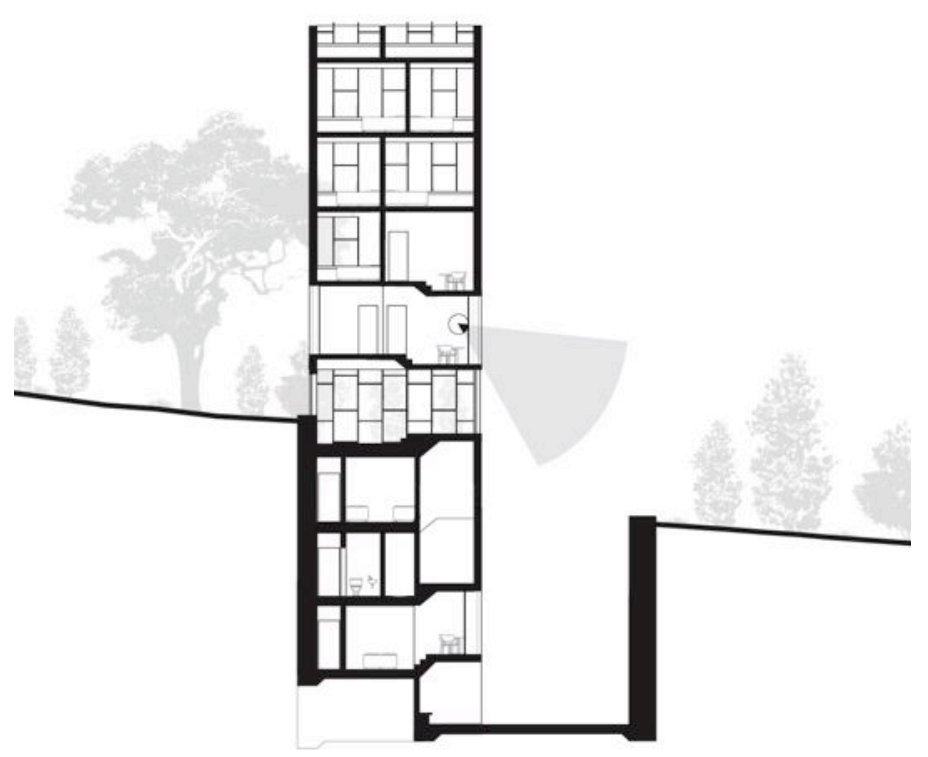

4.6 Occupying the Resort: Two-bedroom Tower Suite (Unit 4.15): Living Space

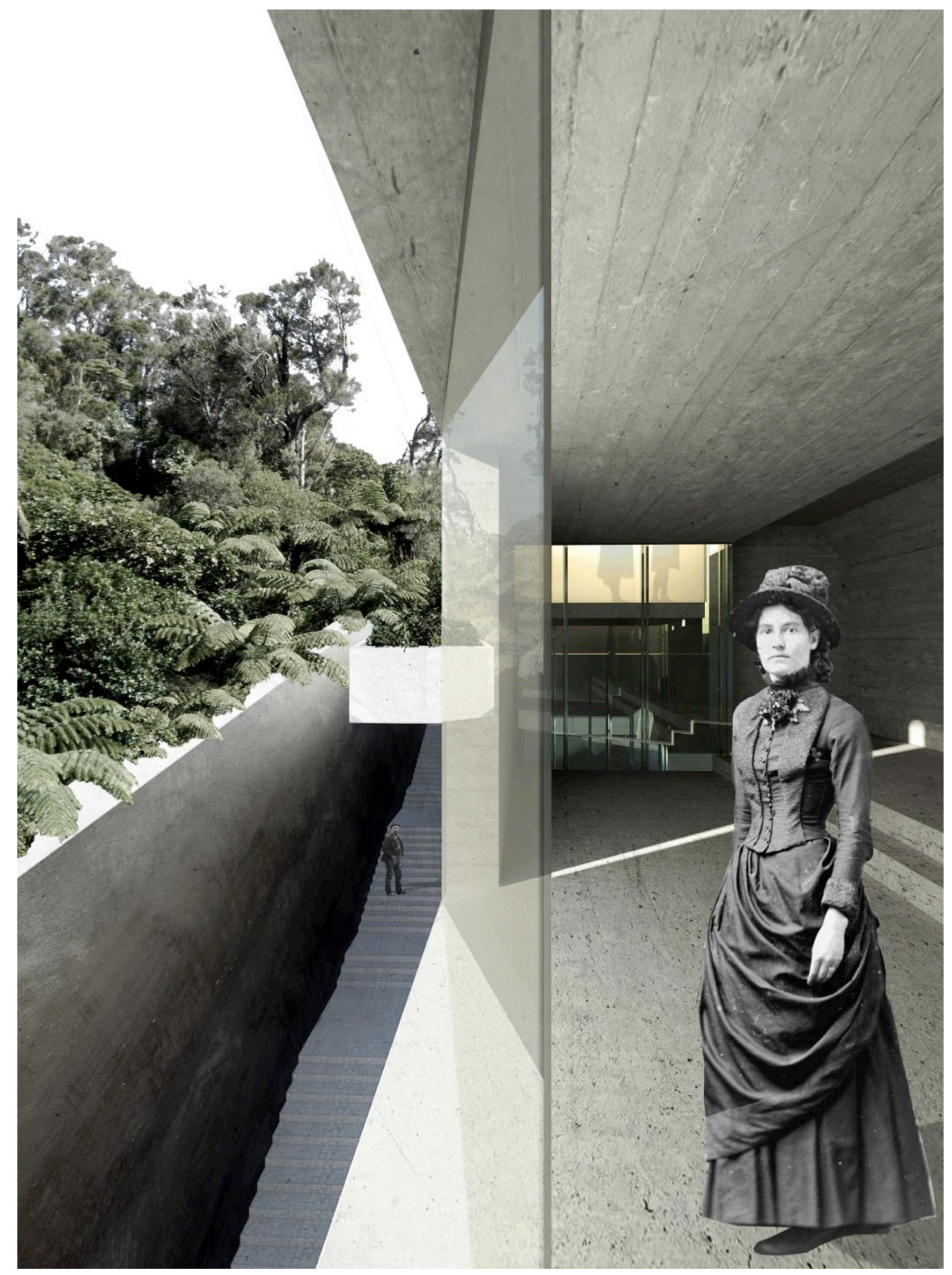




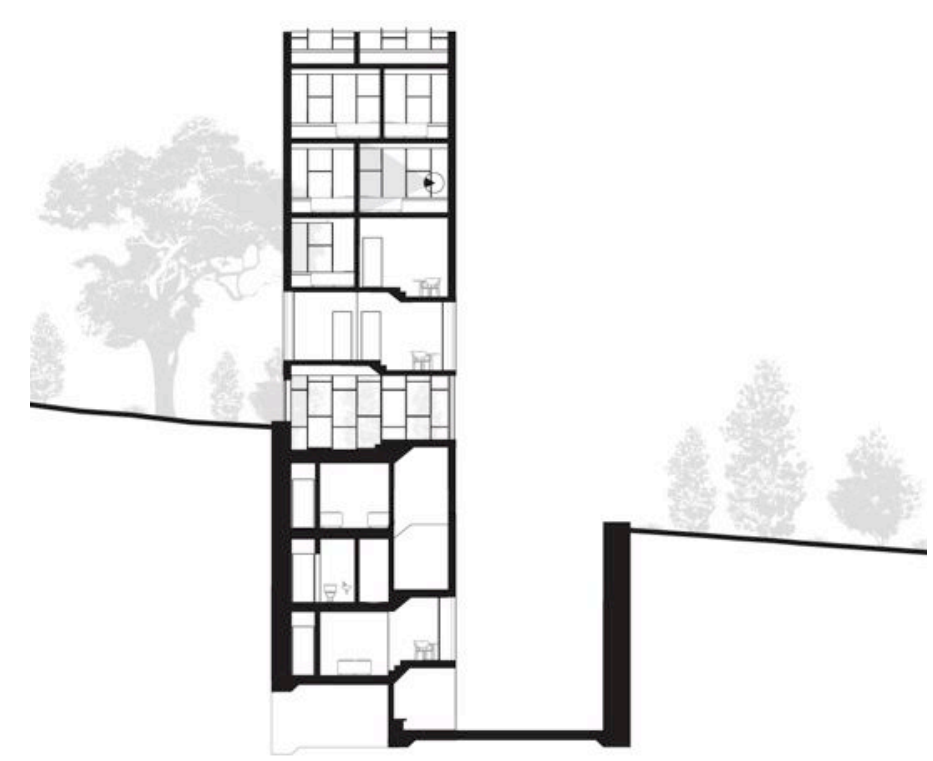

4.7 Occupying the Resort: Two-bedroom Tower Suite (Unit 4.15): Master Bedroom

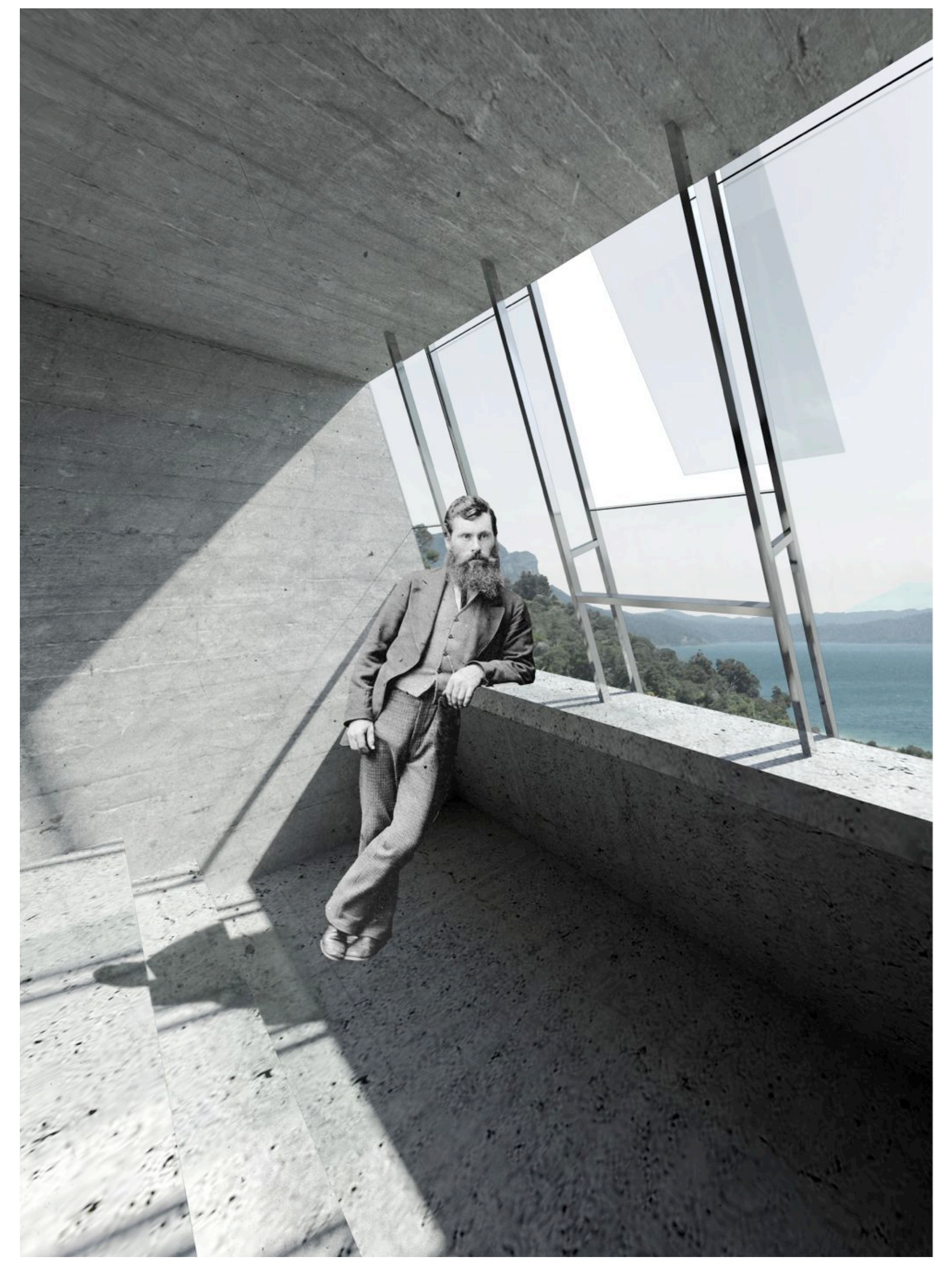




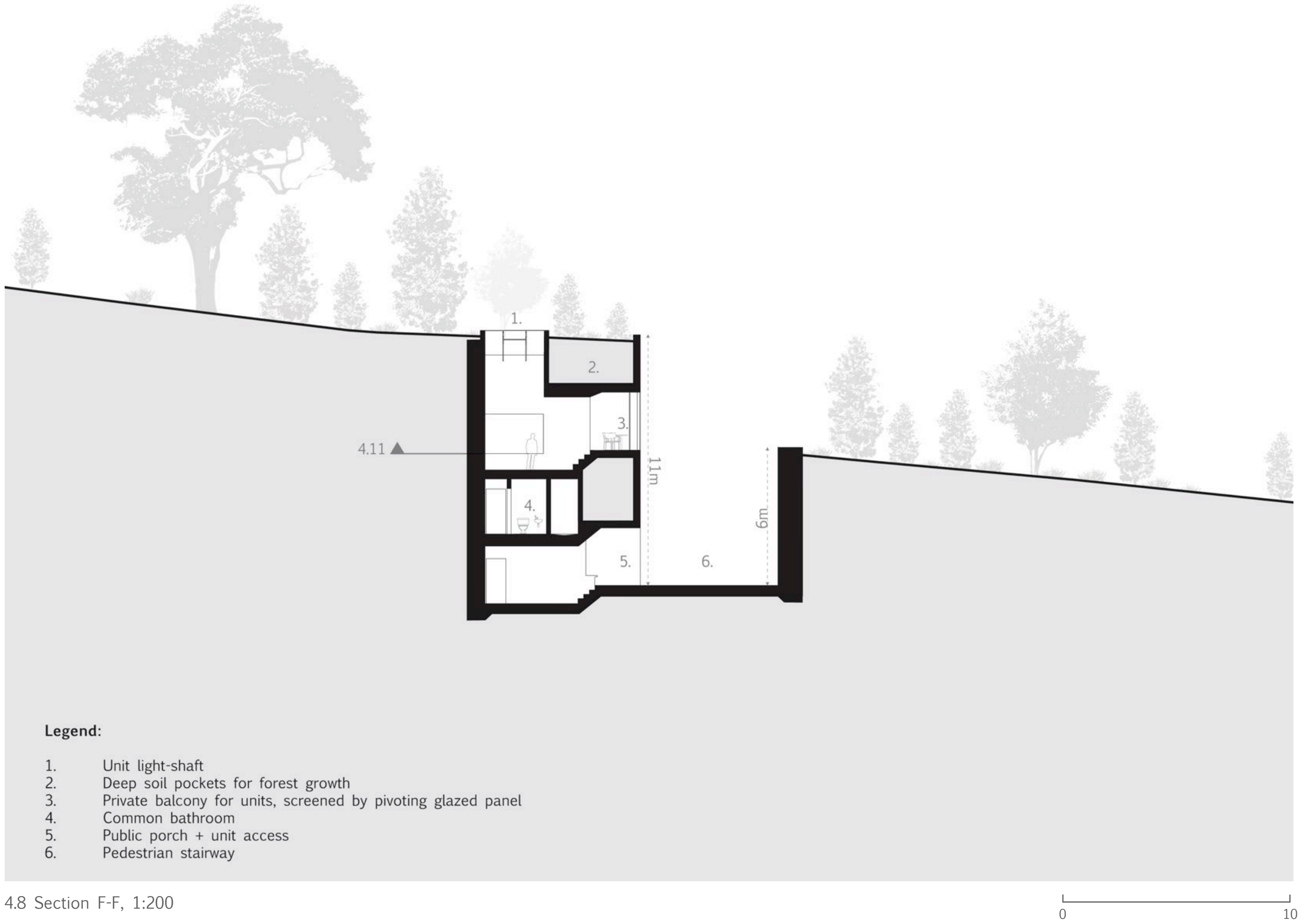




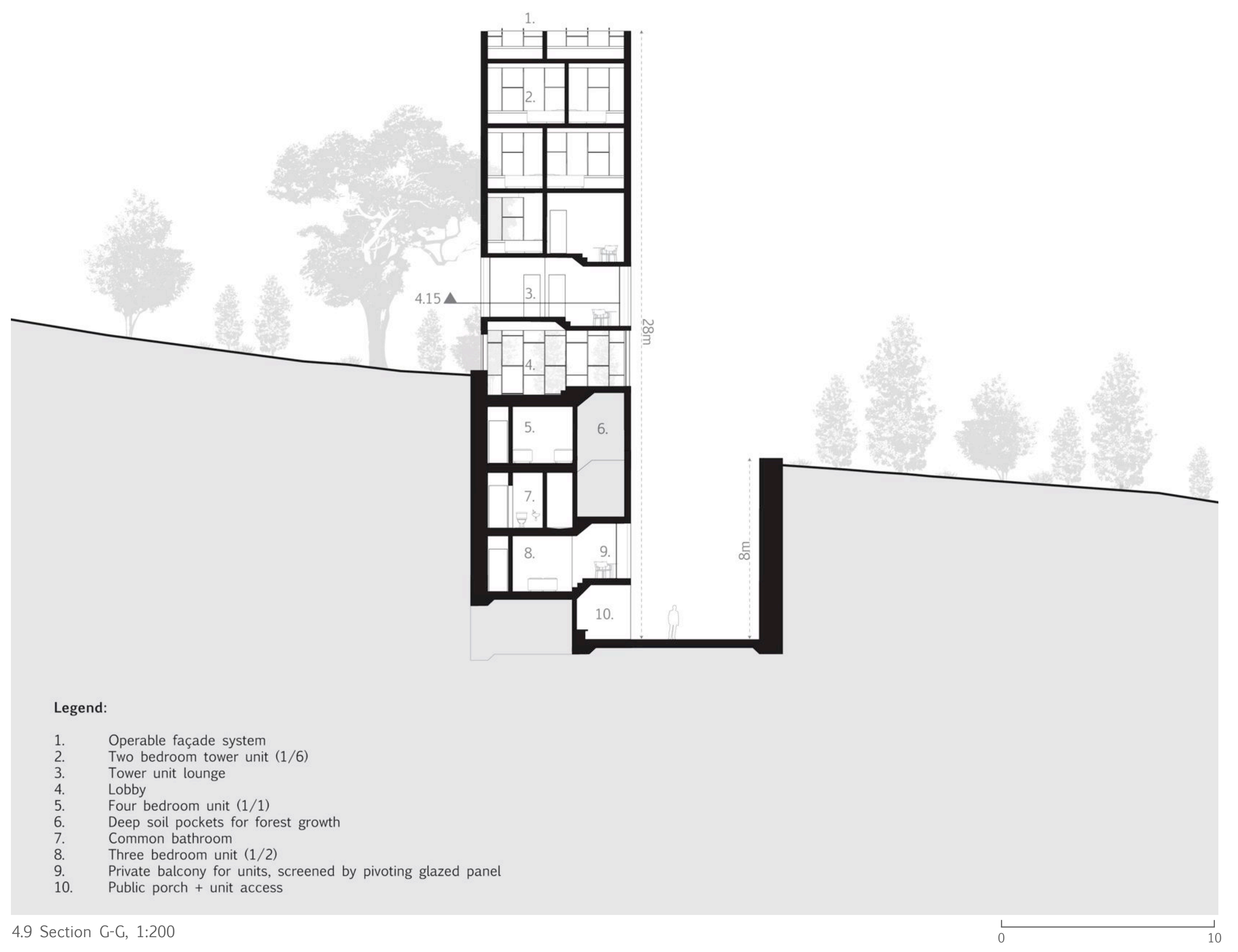




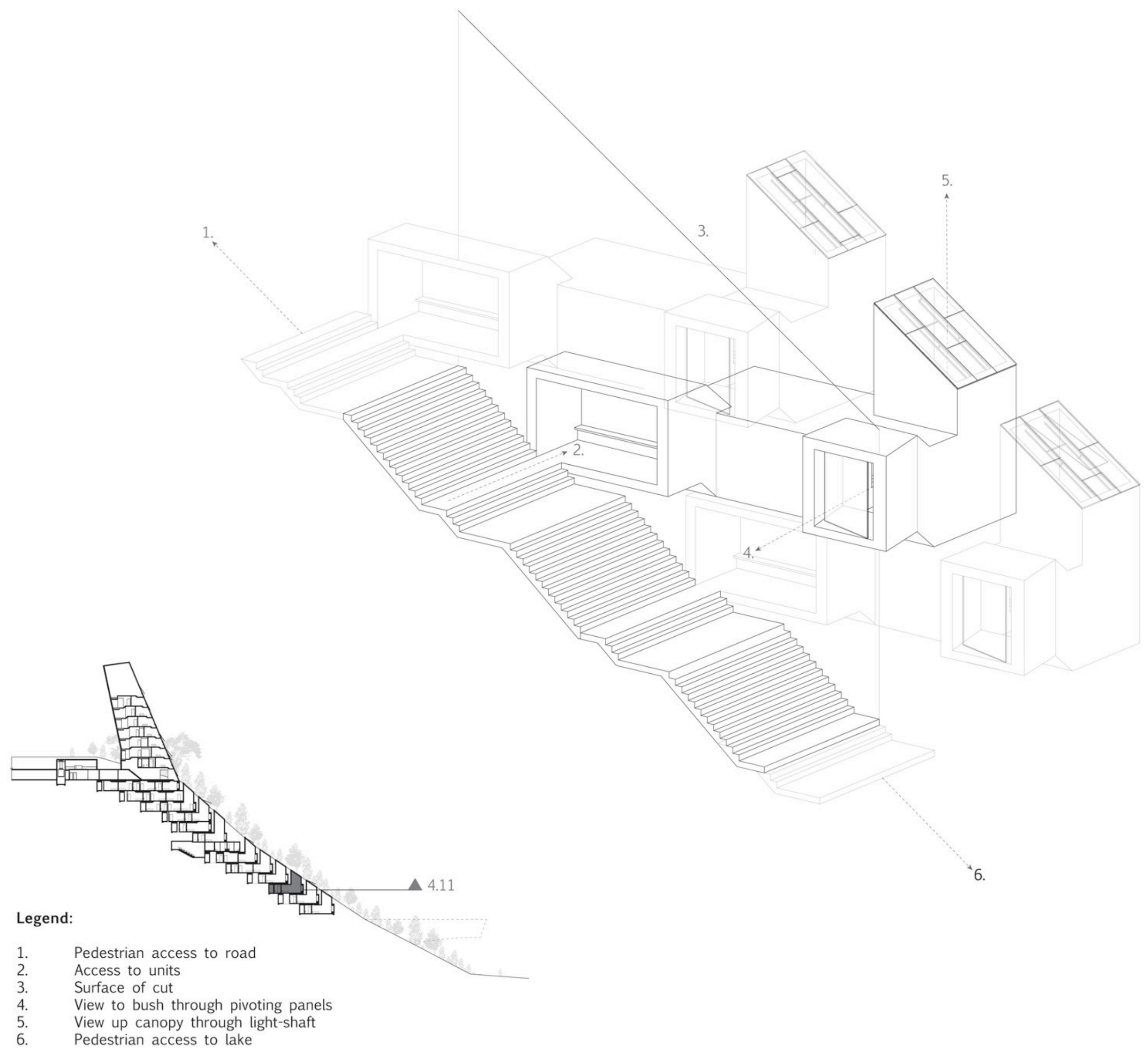

4.10 Executive Suite (Unit 4.11) Axonometric 


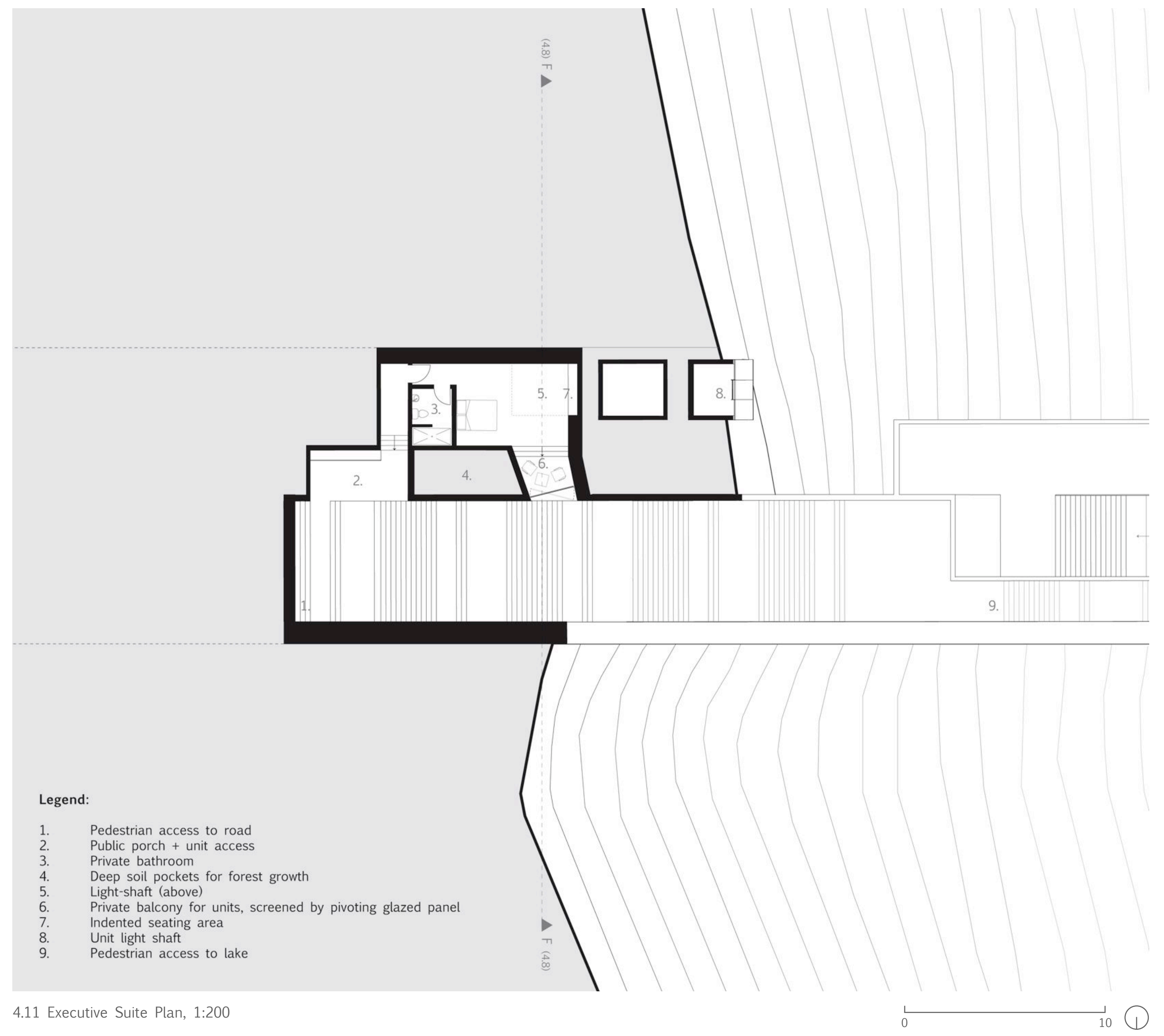




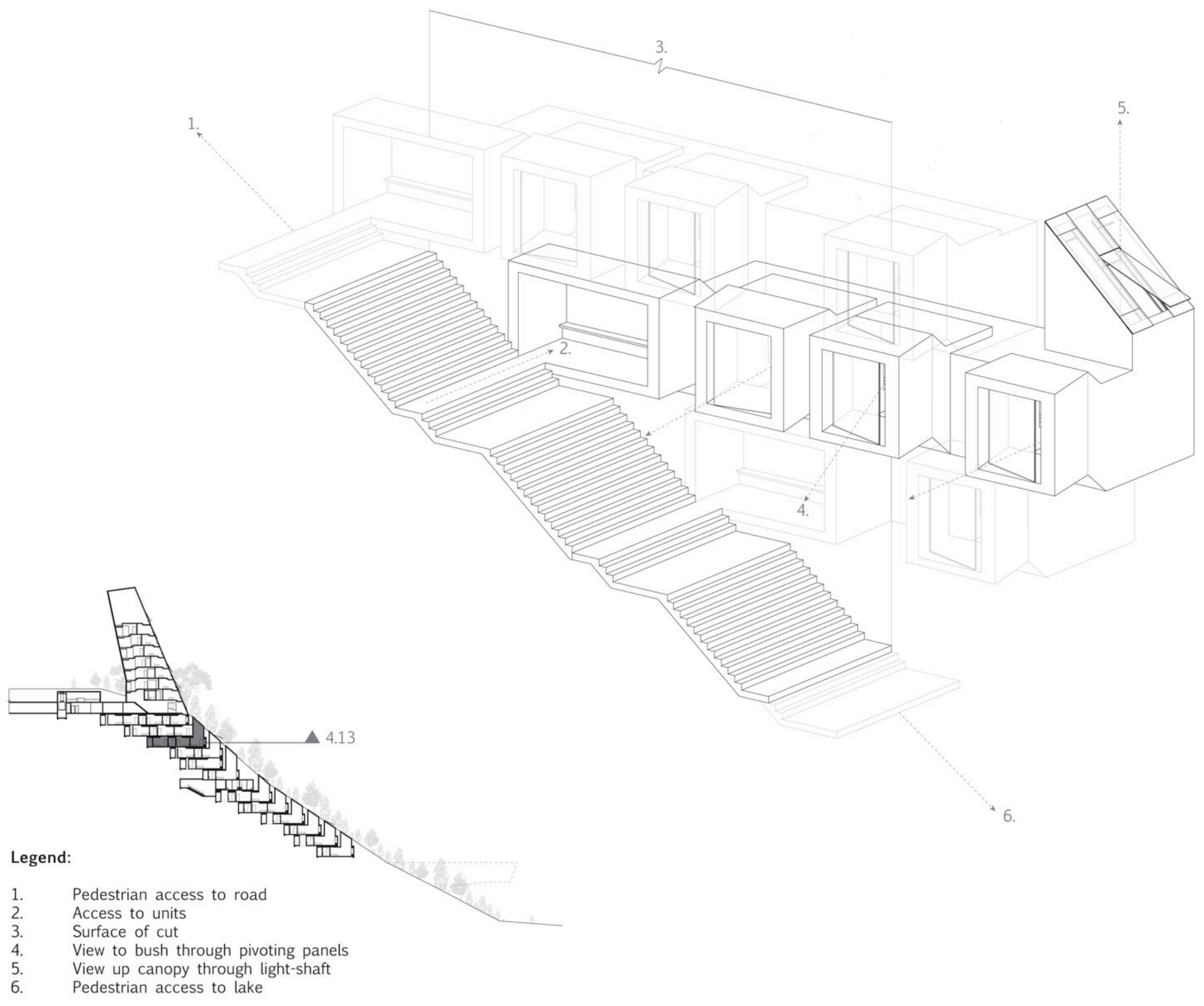

4.12 Three-bedroom Suite (Unit 4.13) Axonometric 


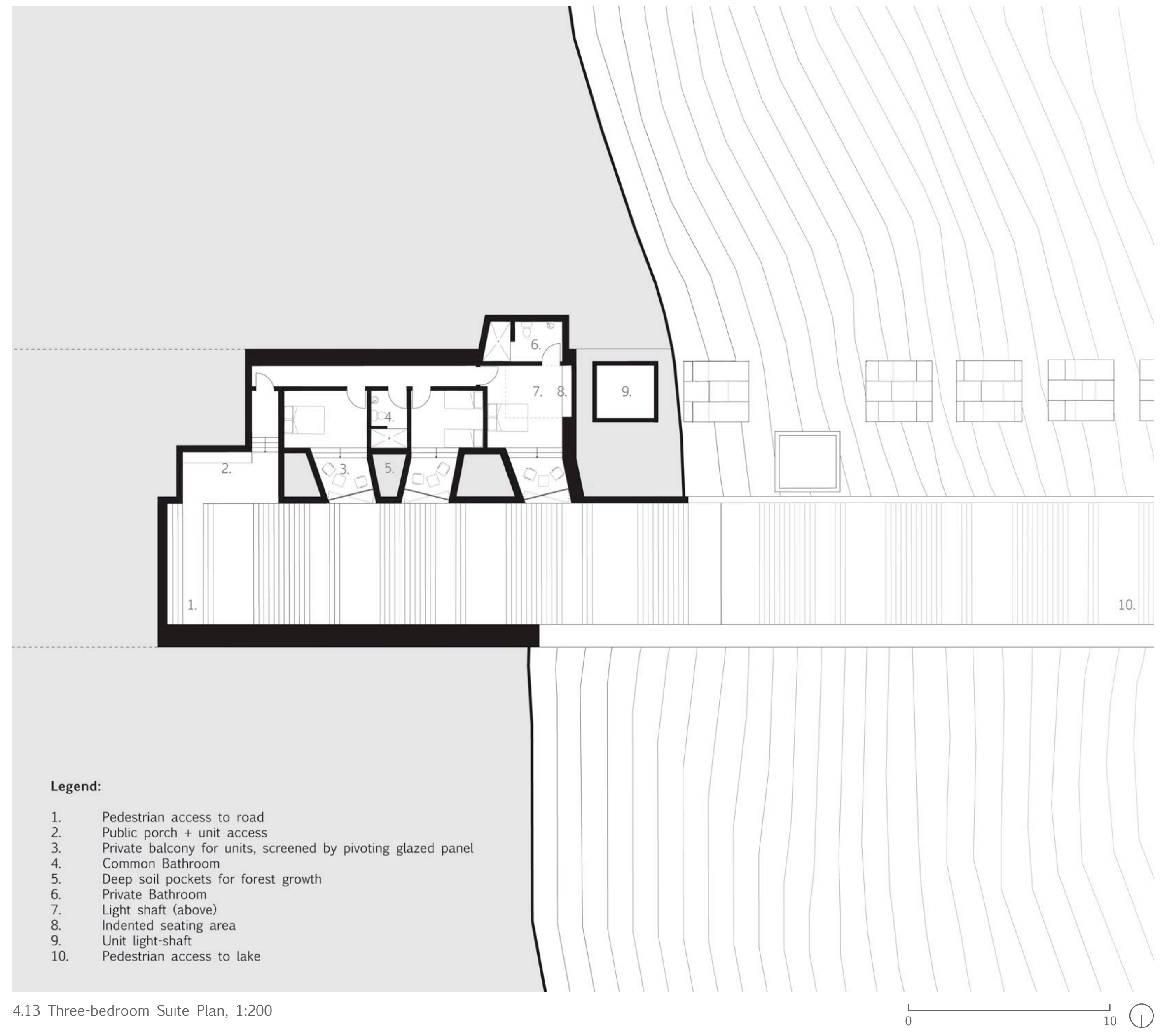




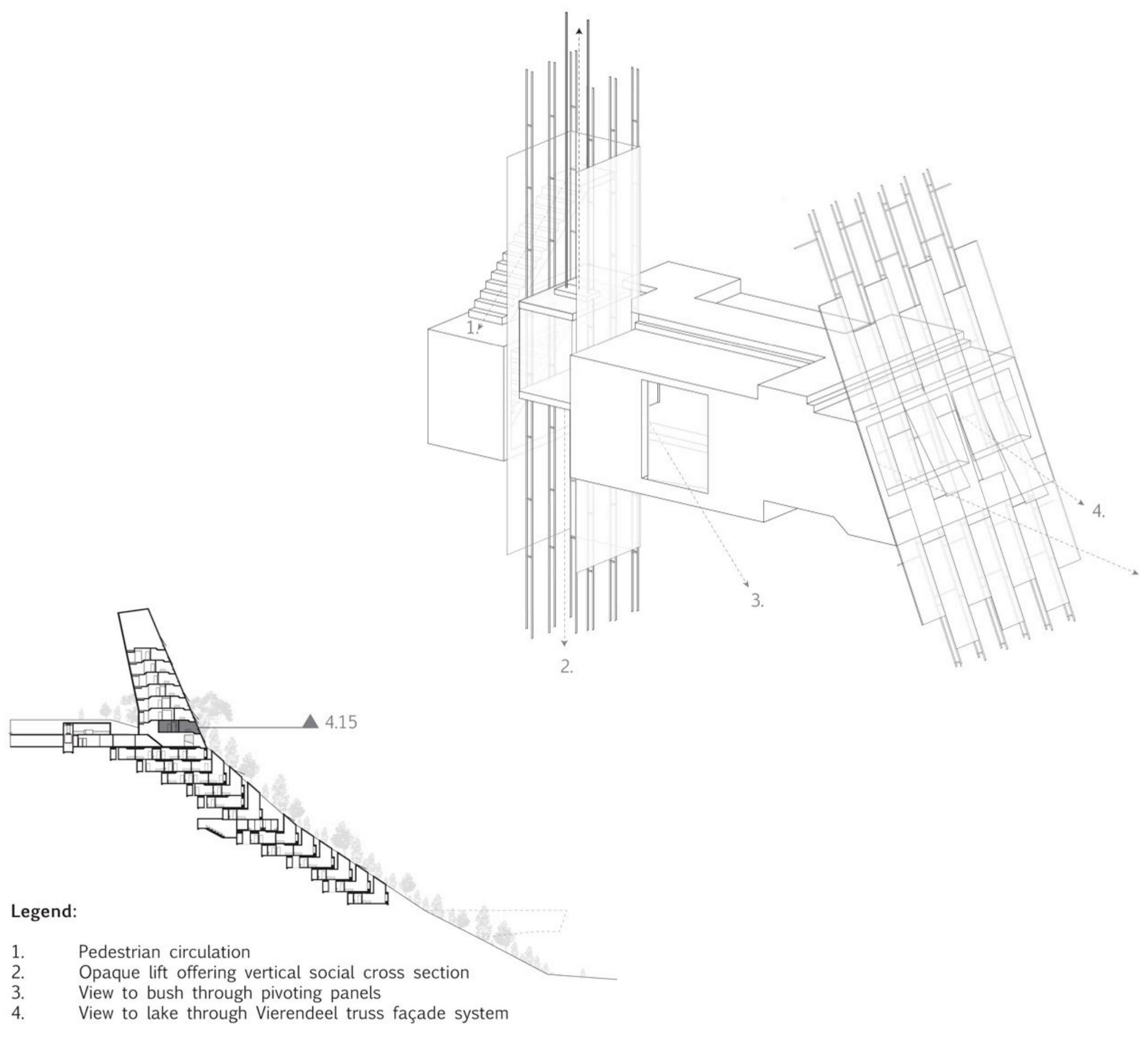

4.14 Two-bedroom Tower Suite (Unit 4.15) Axonometric 


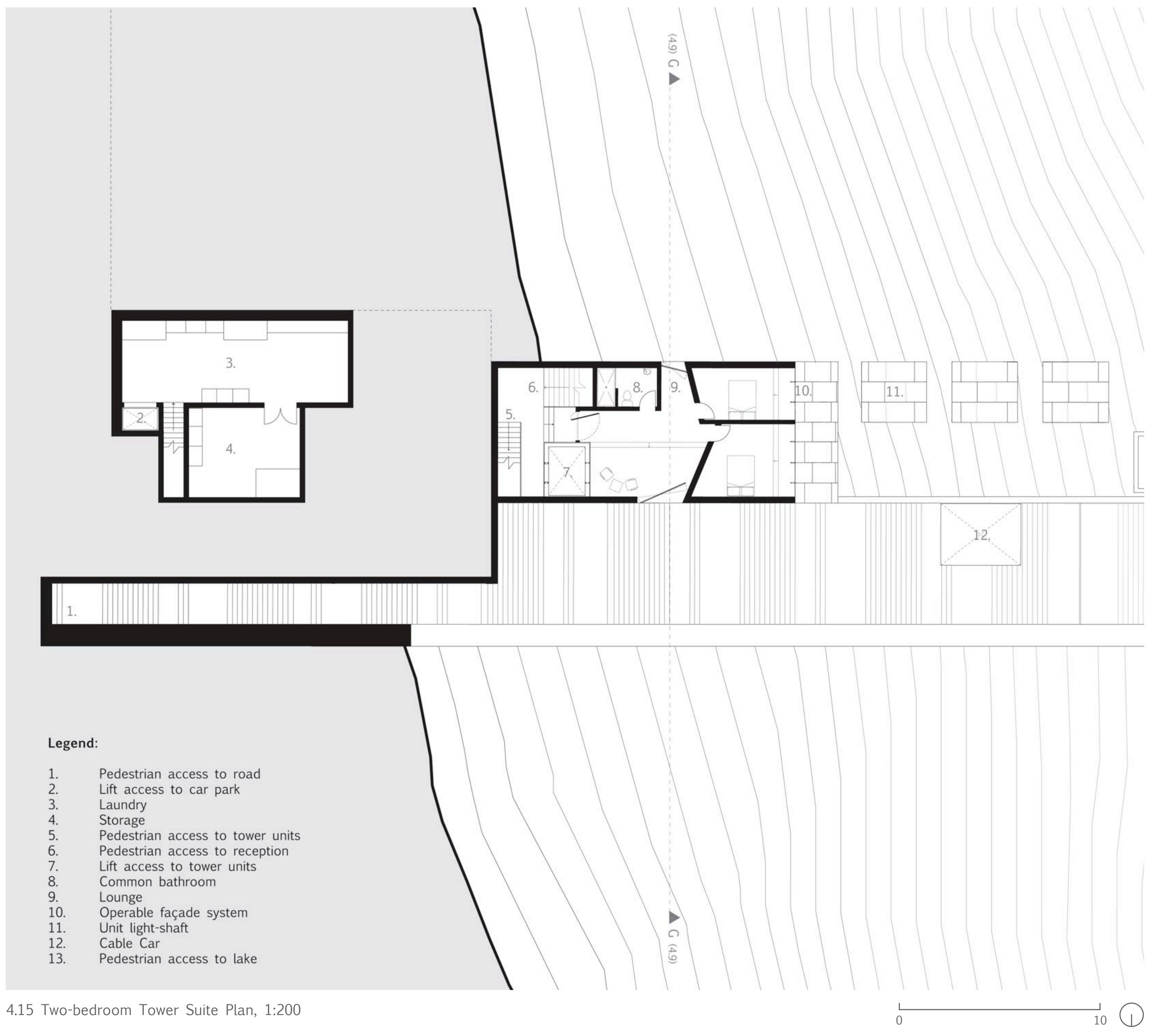




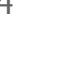
(1) . 


\subsection{Appendix}




\subsection{Site Analysis}

Transecting the densely forested site, the cutting intervention reveals the rich ecologies within Waikaremoana. In a way that ecology is not studied, but felt, the cut encourages inhabitants to attain a deeper understanding of the landscape. Promoting a sense of guardianship, this encourages both visiting and local communities to experience the landscape; the dates of arrivals and departures, the births, the flourishings, the decays, their successions, and natural cycles (Fig 5.2).

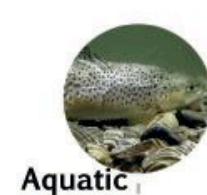

Aquatic
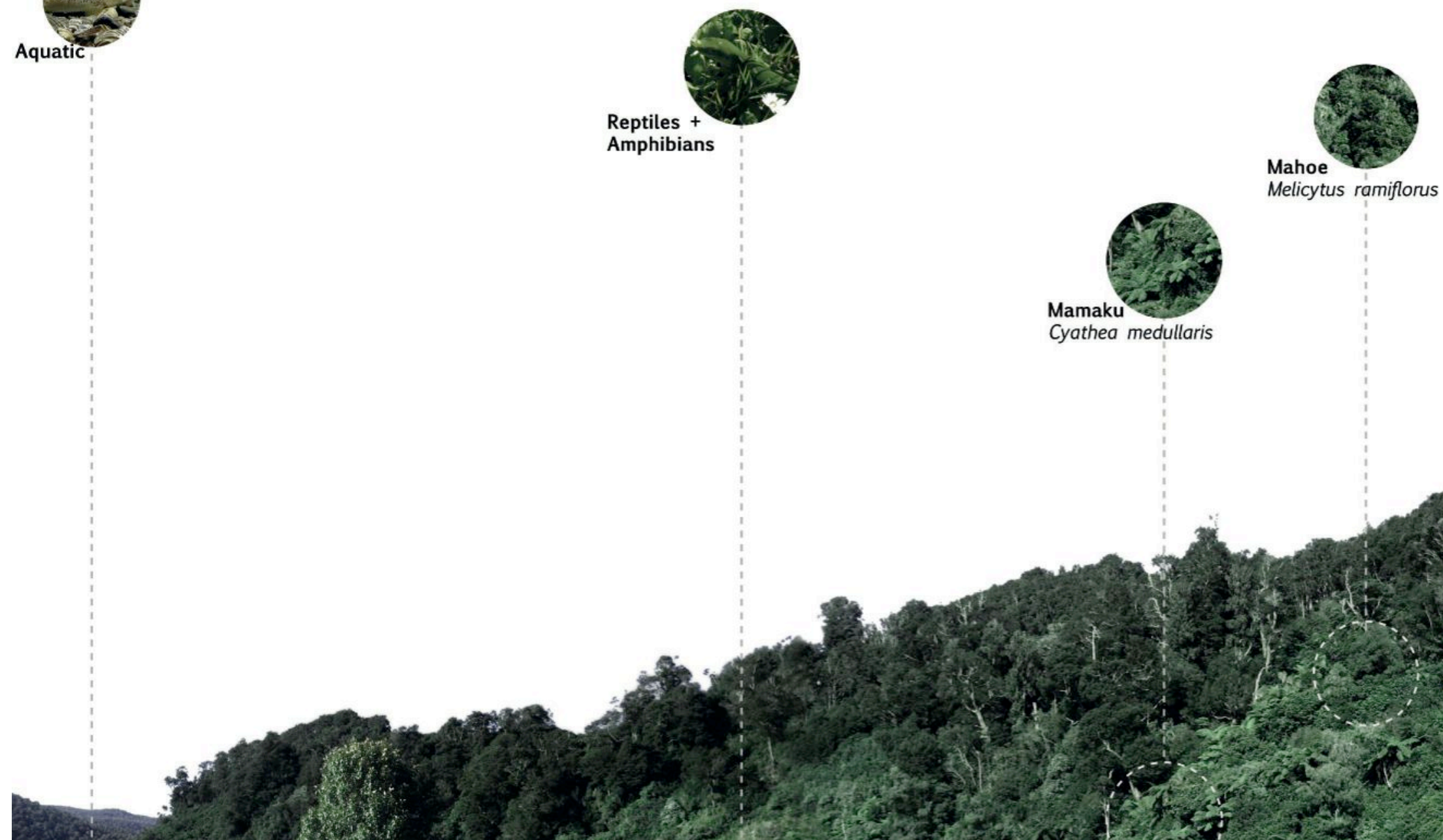

Black beech

Nothofagus solandri var. solandri
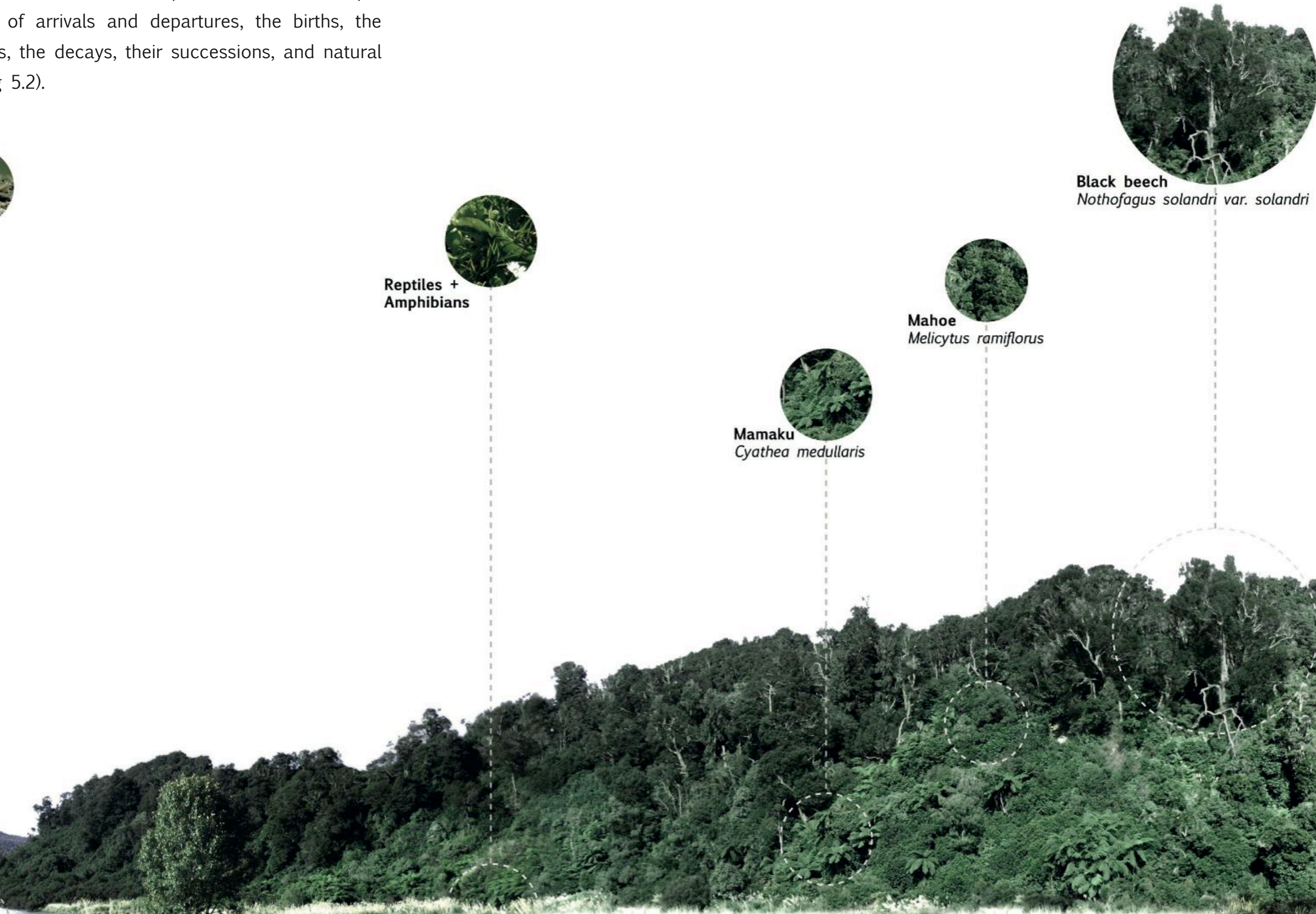

Mahoe

Melicytus ramiflorus

Cyathea medullaris 


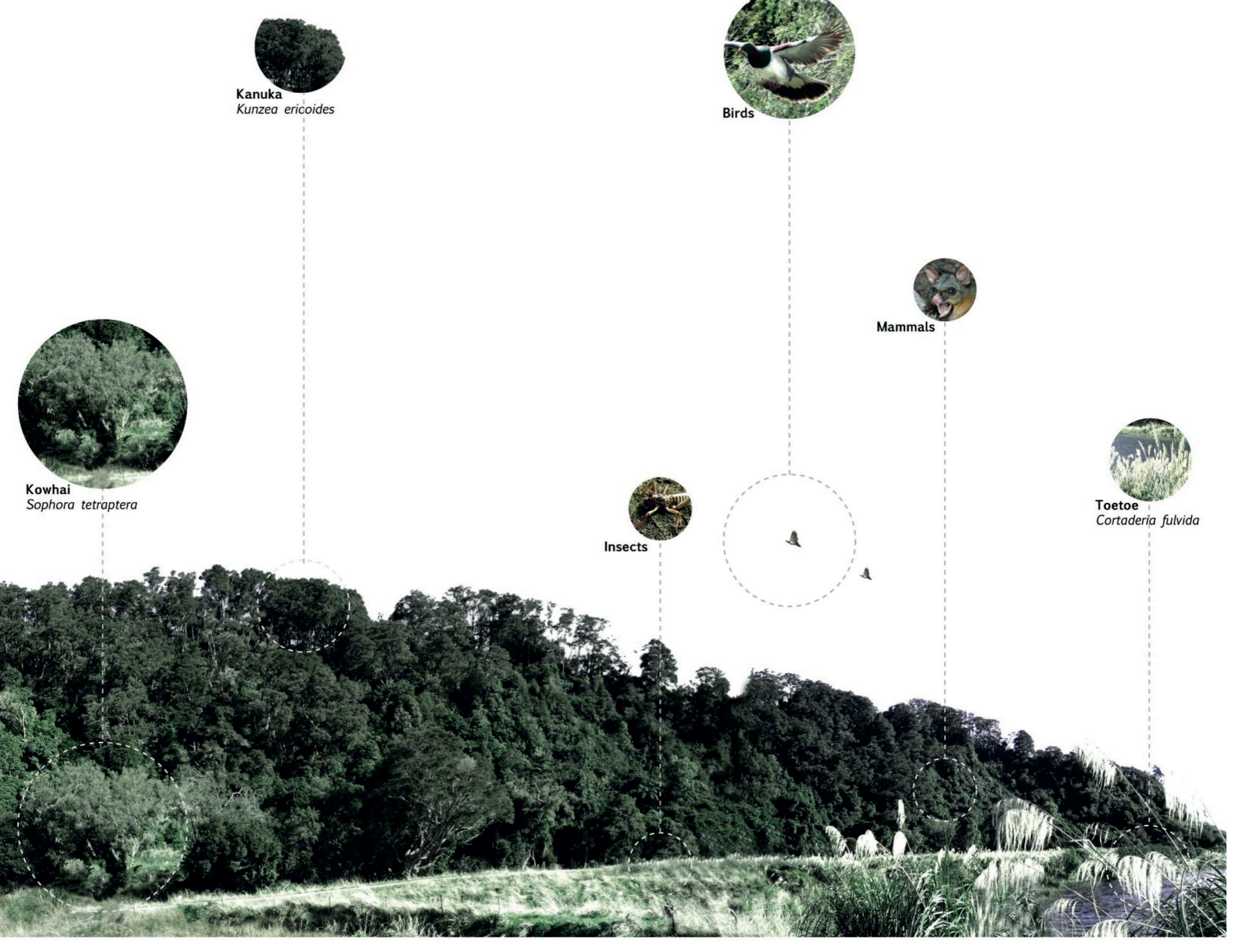


Type:

A common tree

Mamaku ne

Cyathea medullaris

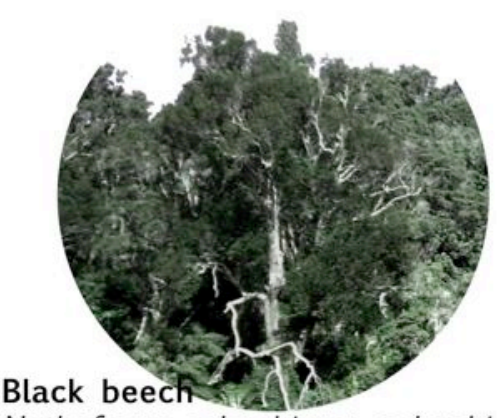

Nothofagus solandri var. solandri

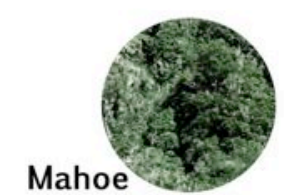

Melicytus ramiflorus

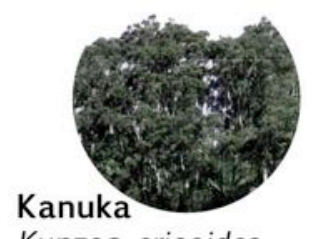

Kunzea ericoides

A Big forest canopy tree

(non threatened)

(non threatened) tree

(non threatened) shrub
Height:

$2-6 m$

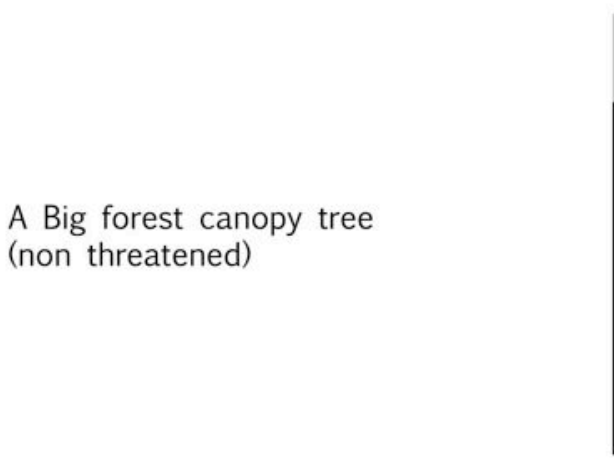

A subcanopy broadleaf shrub/small

$7-9 m$

20-25 m
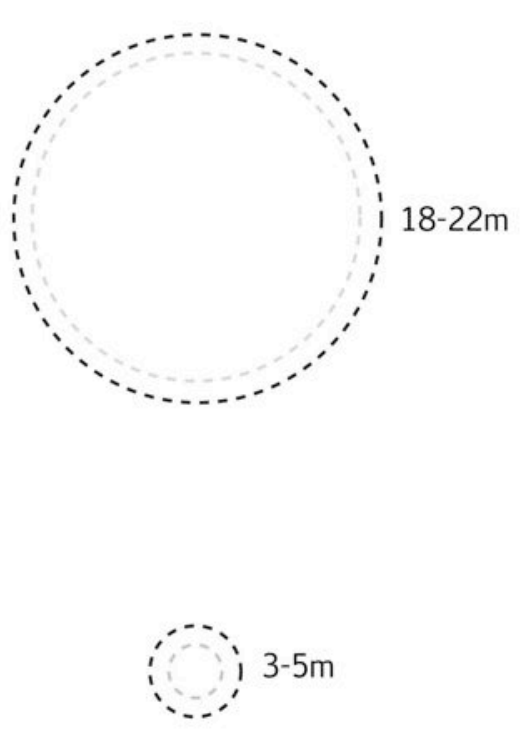

$10-15 m$

(non threatened)

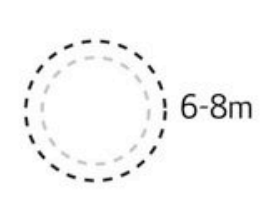

$12-15 m$
Tree

(non threatened)

\section{Canopy:}

Trunk:

Age / Lifespan:

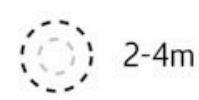

- $0.3 \mathrm{~m}$ diameter

10-20 years
- 0.6-0.8m diameter

- $0.6 \mathrm{~m}$ diameter

80-150 years

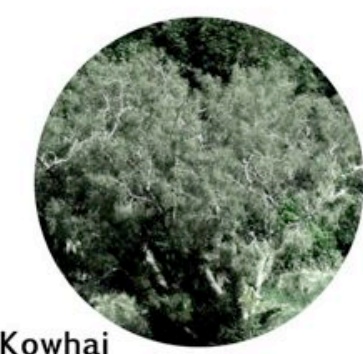

Kowhai

Sophora tetraptera

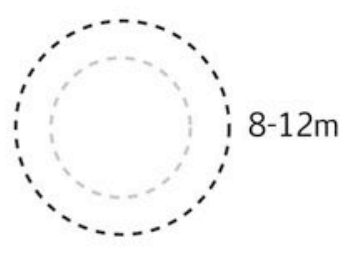


Trunks: Singular

Colour/texture: Black with characteristic hexagonal stipe bases.
Trunks: Singular

Colour/texture: Sooty black mold covers the trunk and branches.

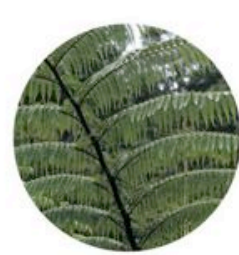

Fronds up to $5 \mathrm{~m}$ long. Dark green above, pale green below.
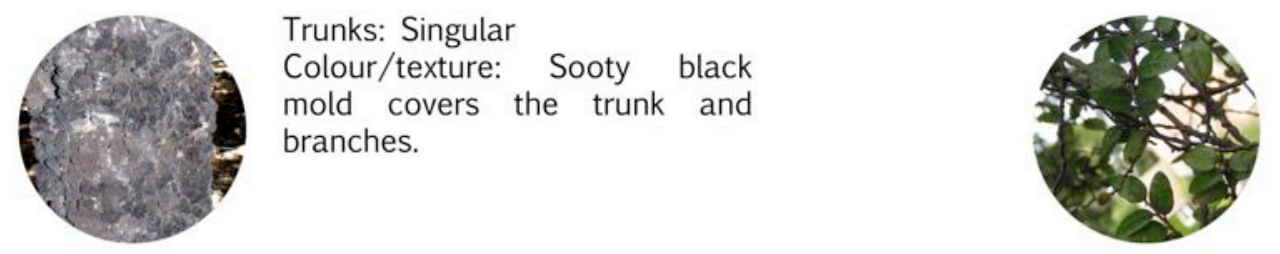

Leaves are alternately arranged, ovoid, $10 \mathrm{~mm}$ long and $5 \mathrm{~mm}$ broad, with smooth margins.
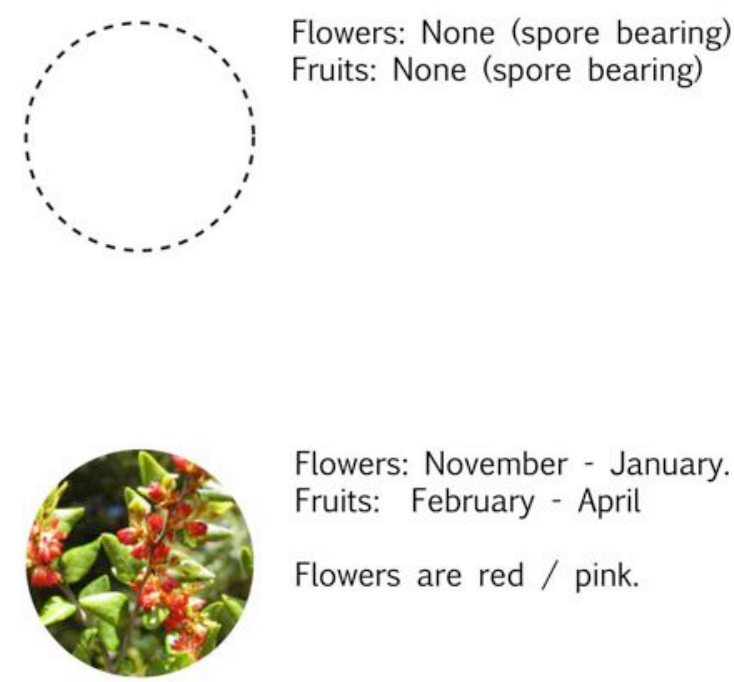

Flowers: November - January Fruits: February - April Flowers are red / pink.

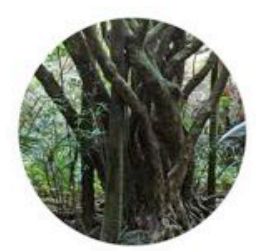

Trunks: Typically more than one Colour/texture: Bark greyishwhite, underbark bright green. Branchlets numerous, twiggy, rather brittle. Wood: Soft.

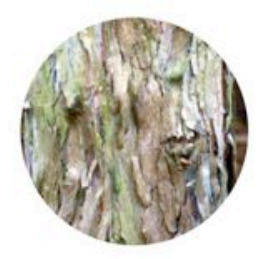

Trunks: Typically single and slender

Colour/texture: Bark brown, loose, flaking readily into fibrous shards with much secondary peeling; like wood shavings.

Wood: Kanuka wood is tough and is noted for its straight grain, durability and strength.

Trunks: Often several

Colour/texture: Smooth bark.

Wood: Branches numerous and

spreading. Young branchlets

clad in fulvellous tomentum.
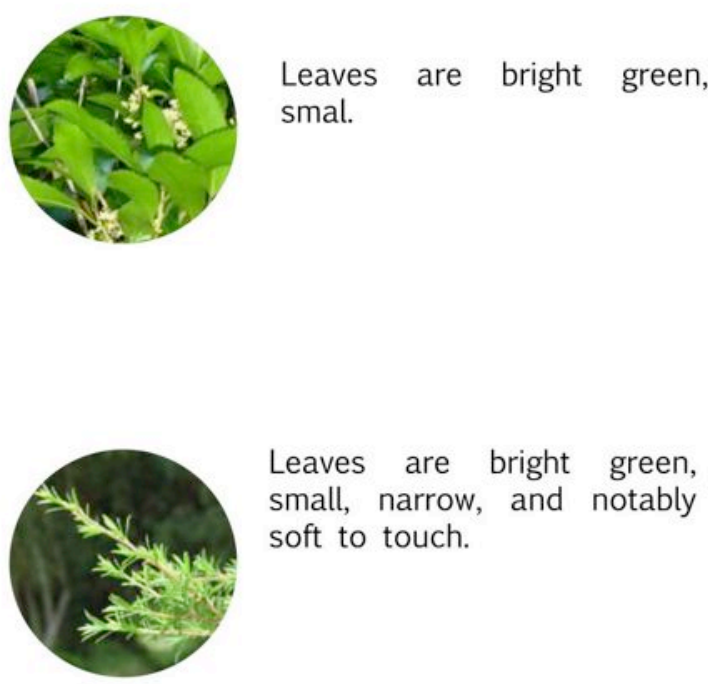

Leaves are bright green, small, narrow, and notably soft to touch.

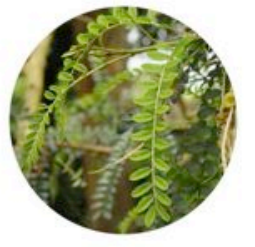

Leaves are delicate and feathery, following a weeping form. Up to $15 \mathrm{~cm}$ or more long, with $10-20$ pairs of $1.5 \times 3.5 \mathrm{~cm}$ ovate leaflets, clad above and below with silky appressed hairs.

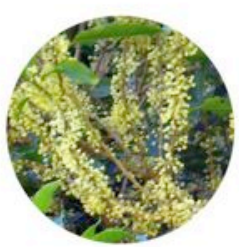

Flowers: November - Febru-

ruits: November - March

Small yellowish flowers, with a strong, pleasant fragrance, $3-4 \mathrm{~mm}$ in diameter and occur in fascicles.

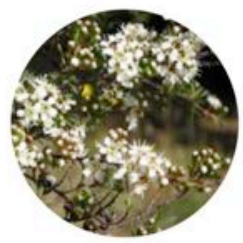

Flowers: October-February Fruits: November - March

Small creamy white flowers, strongly scented, up to $5 \mathrm{~mm}$ diameter, tending to be in dense clusters towards the end of the branches.

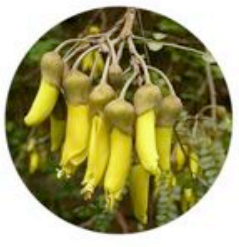

Flowers: September - December

Fruits: October-May

Flower abundantly in spring with up to $5 \mathrm{~cm}$ long, golden yellow horn-shaped flowers. 


\subsection{Density Comparisons}

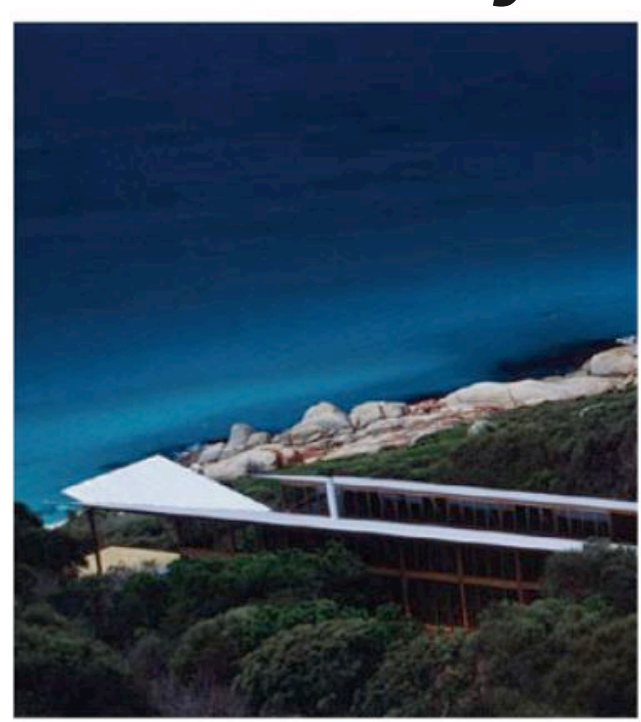

Retrieved from www.bayoffires.com.au

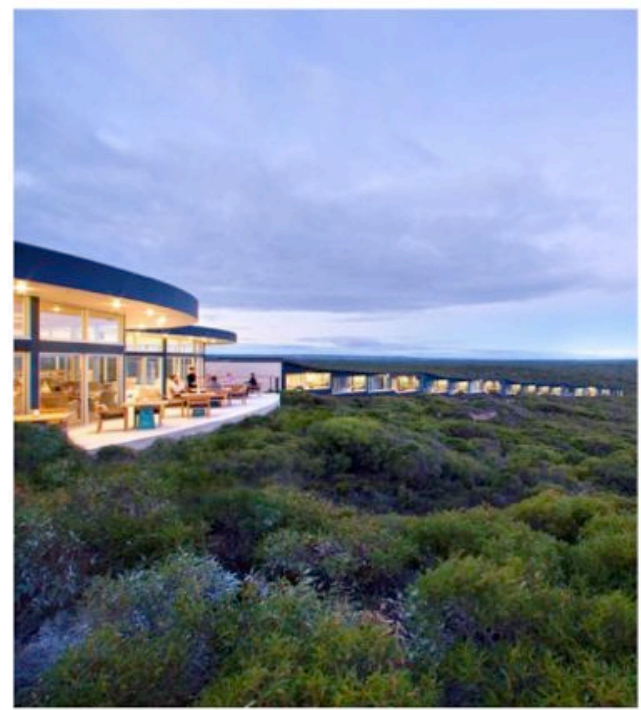

Retrieved from www.southernoceanlodge.com.au

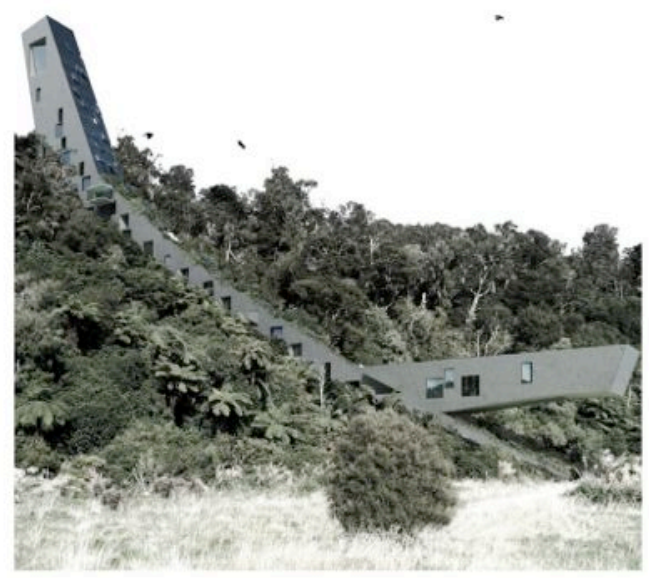

5.3 Density Comparison 1: Bay of Fires Lodge, Ken Latona, 2000.

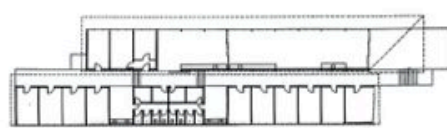

Footprint: $500 \mathrm{~m} 2$

Floor Area: $500 \mathrm{~m} 2$

5.4 Density Comparison 2: Southern Ocean Lodge, Max Pritchard Architect, 2008.

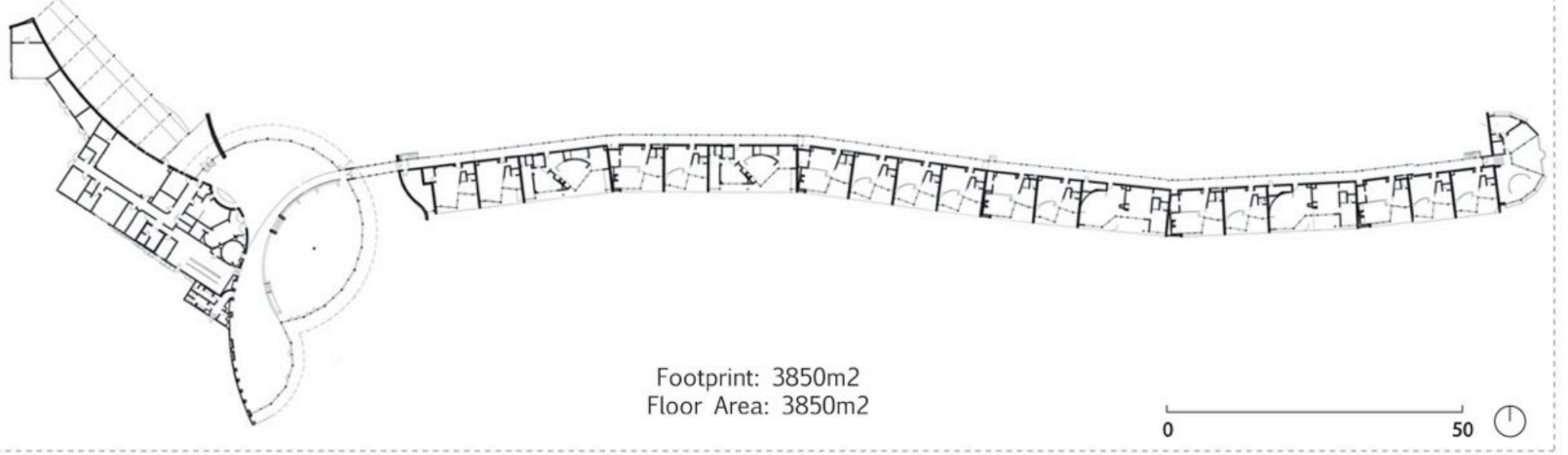

5.5 Density Comparison 3: Scheme 


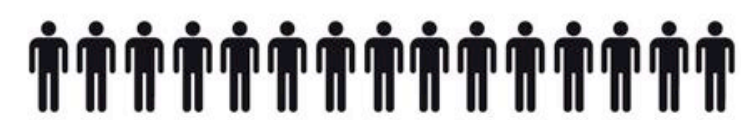

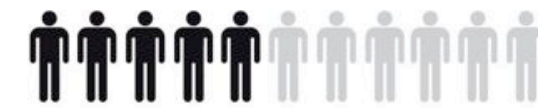

Footprint: m2 Per Person

$20 / 6$

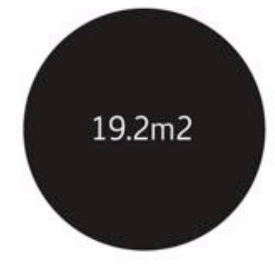

visitors/staff

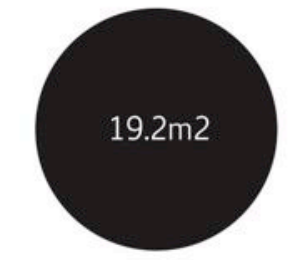

Floor Area: m2 Per Person
While Ken Latona's Bay of Fire's Lodge (2000) maintains an ecologically sensitive small building footprint, its occupancy capacity is limited to only 20 people. Consisting of only one storey, the average floor area per person is also limited, resulting in lower comfort levels and crowding of guests.

Max Pritchard's Southern Ocean Lodge (2008) has the capacity to occupy far more people (73) in a more spacious environment. The cost of this, however, is an ecologically compromising large building footprint.

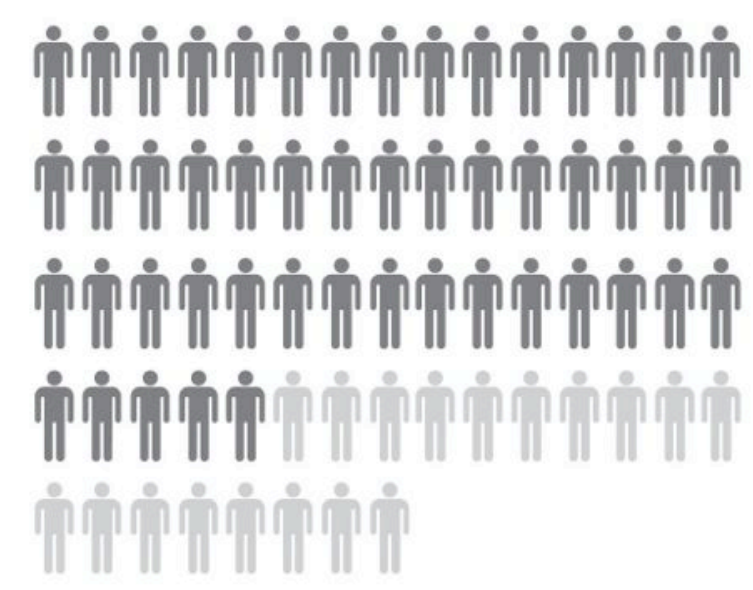

visitors+locals/staff
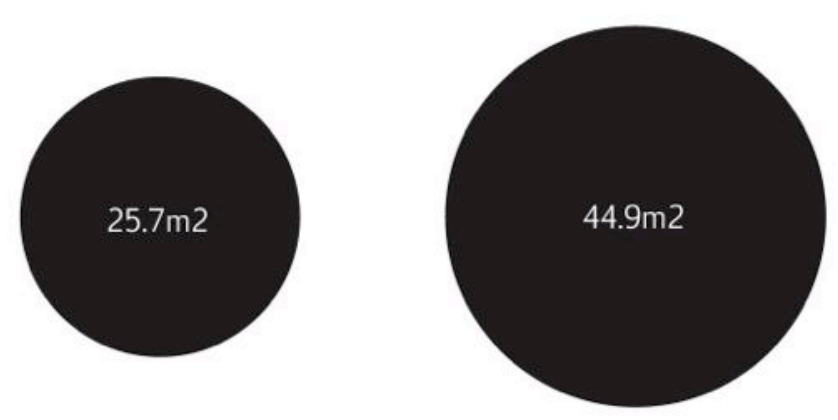

Footprint: m2 Per Person

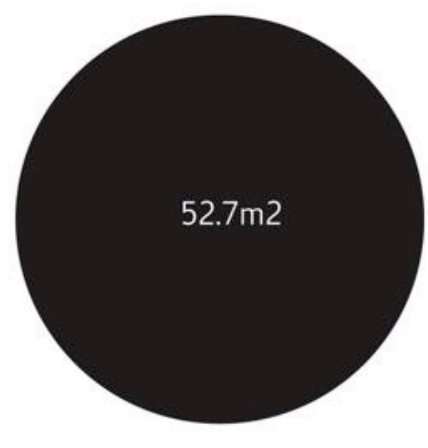

Floor Area: m2 Per Person

$46 / 27$

Employing density, the proposed scheme accommodates a similar capacity of people (68) to Southern Ocean Lodge, with comparable floor area per person, while maintaining a modest footprint proportional to Bay of Fires Lodge. 


\subsection{Process}

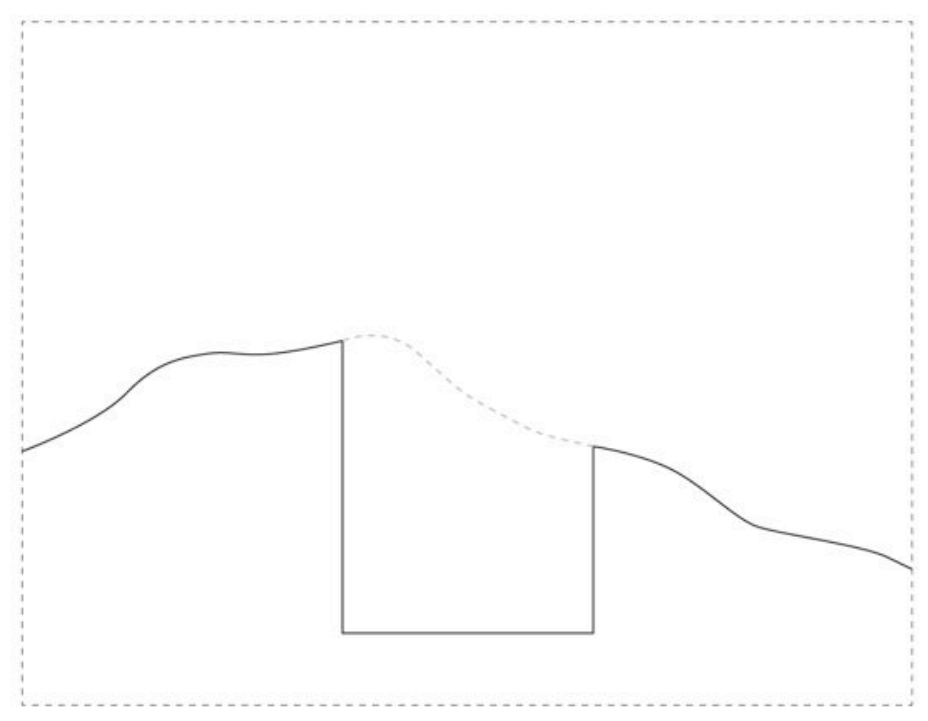

5.6: Initial Response: The cut

An intuitive design process Initially unearthed linear and cutting formal strategies that operated against the contours of the site (Fig 5.9). After identifying a singular cutting intervention could enhance the site, while offering an ecological and cultural cross section, a formal proposition was posed; how could one occupy a cut in the landscape? Engaging drawing, computer modeling and physical modeling responses explored monolithic forms (Fig 5.7) and multiple towers (Fig 5.8 $\&$ 5.10) positioned both in and out of the cut.

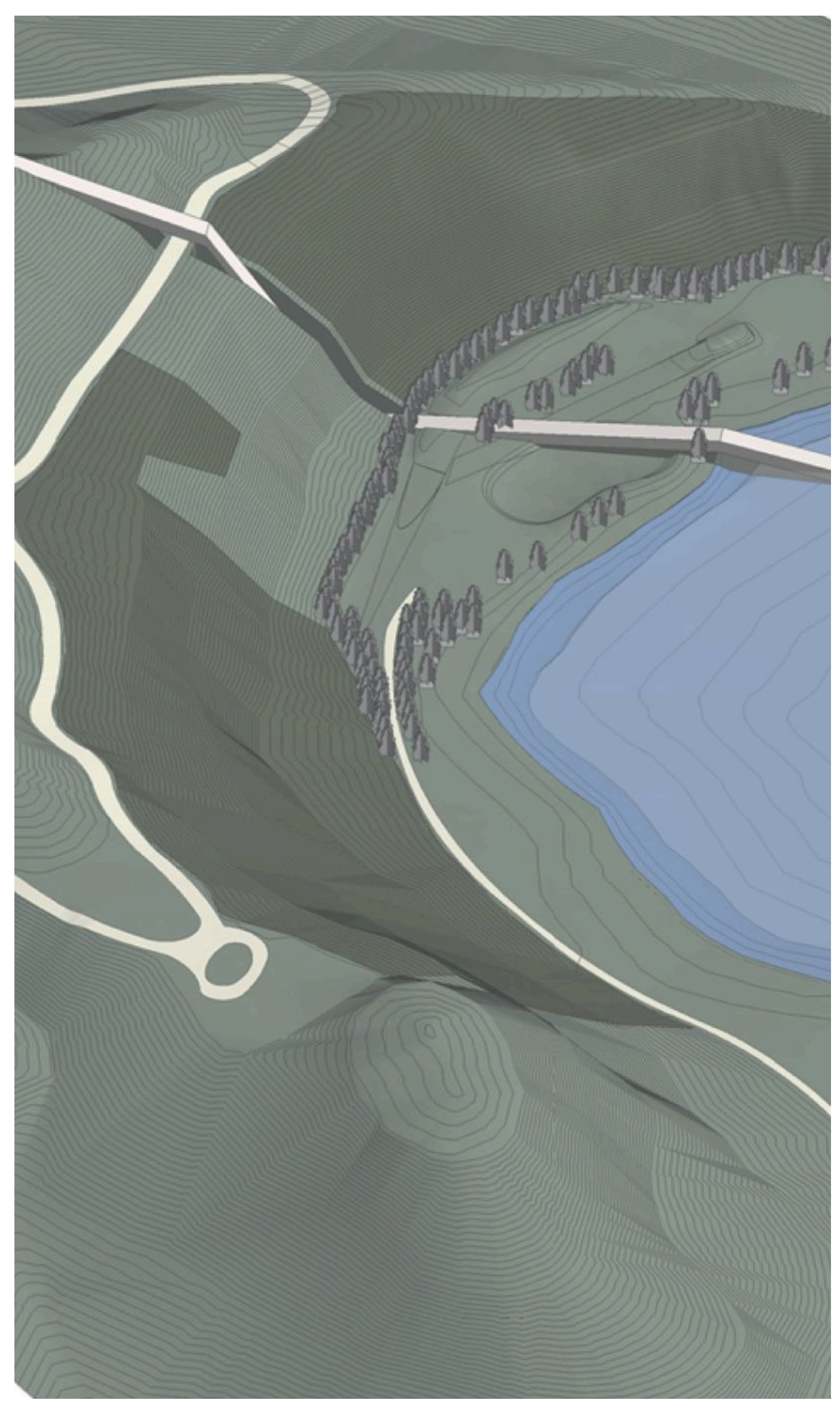

5.7 Initial Response: Cutting the Landscape 
Initial Response: The Cut

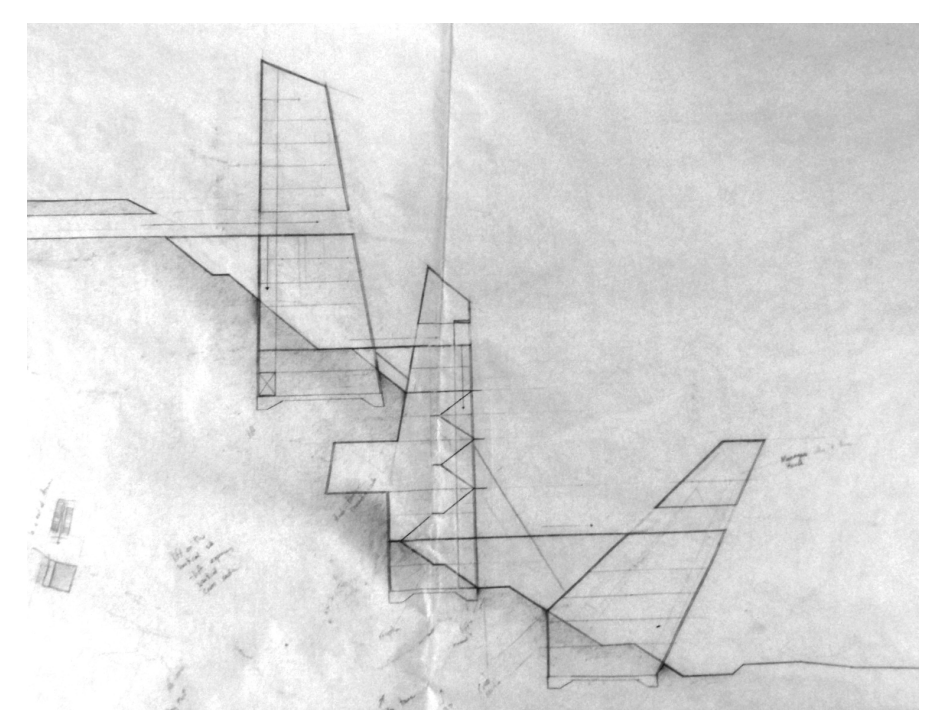

5.8 Initial Response: Three Tower Scheme

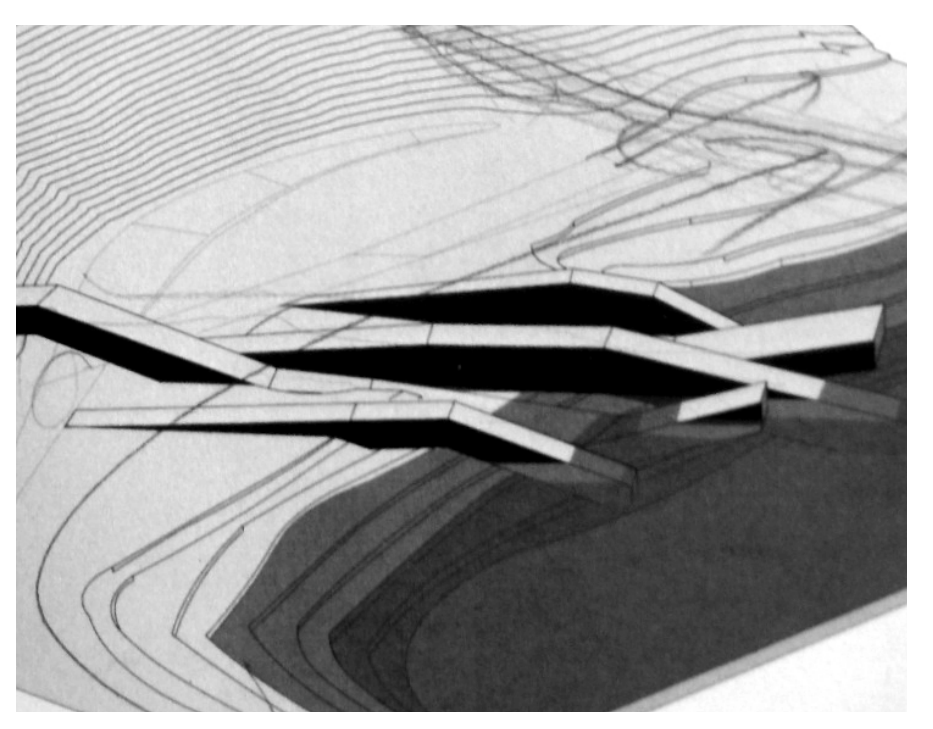

5.9 Initial Response: Linear Strip

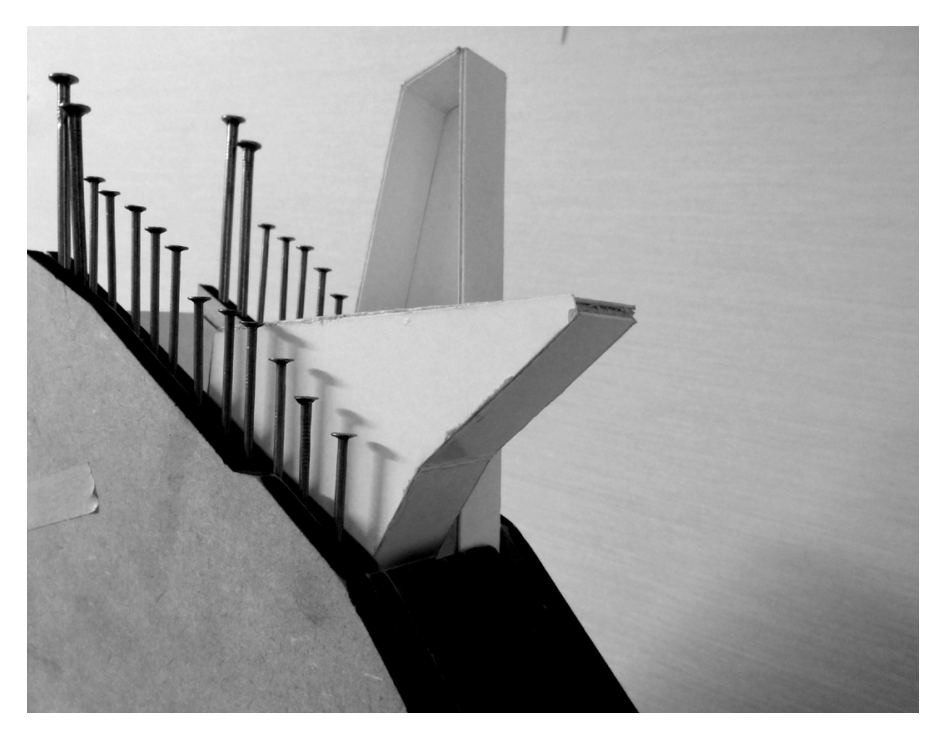

5.10 Initial Response: Tower Modeling 


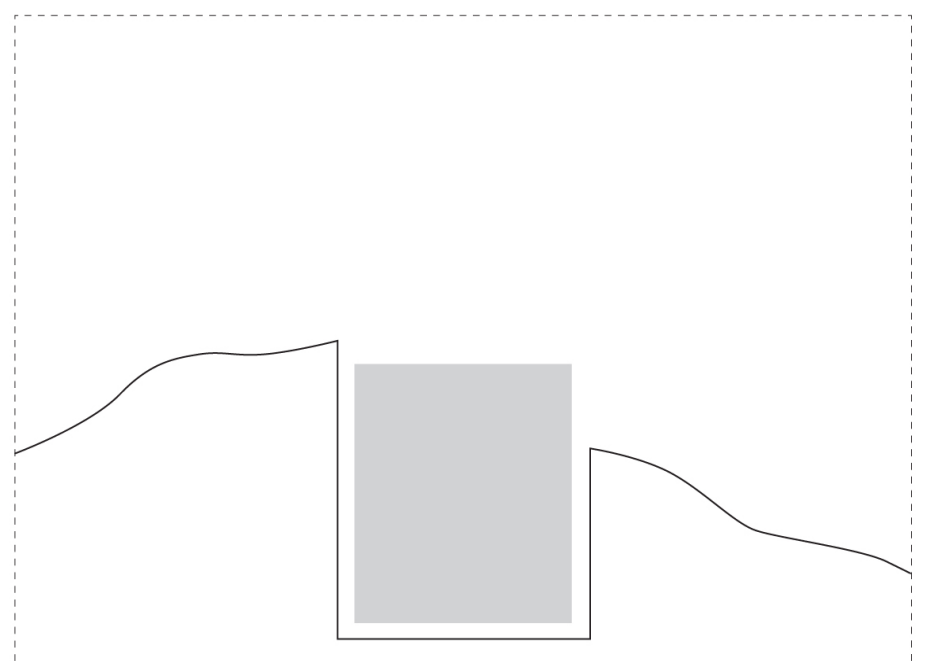

5.11 Occupying the Cut: Replaced Mass

The first concept design completely occupied the cut with built form - failing to exploit the spatial conditions of the cut. This strategy offered a limited ecological cross section of the site, and failed to engage with cultural integration. Spatially inefficient circulation, in the form of escalators, generated accessibility problems (Fig 5.13), highlighting the importance of a clear circulation strategy.

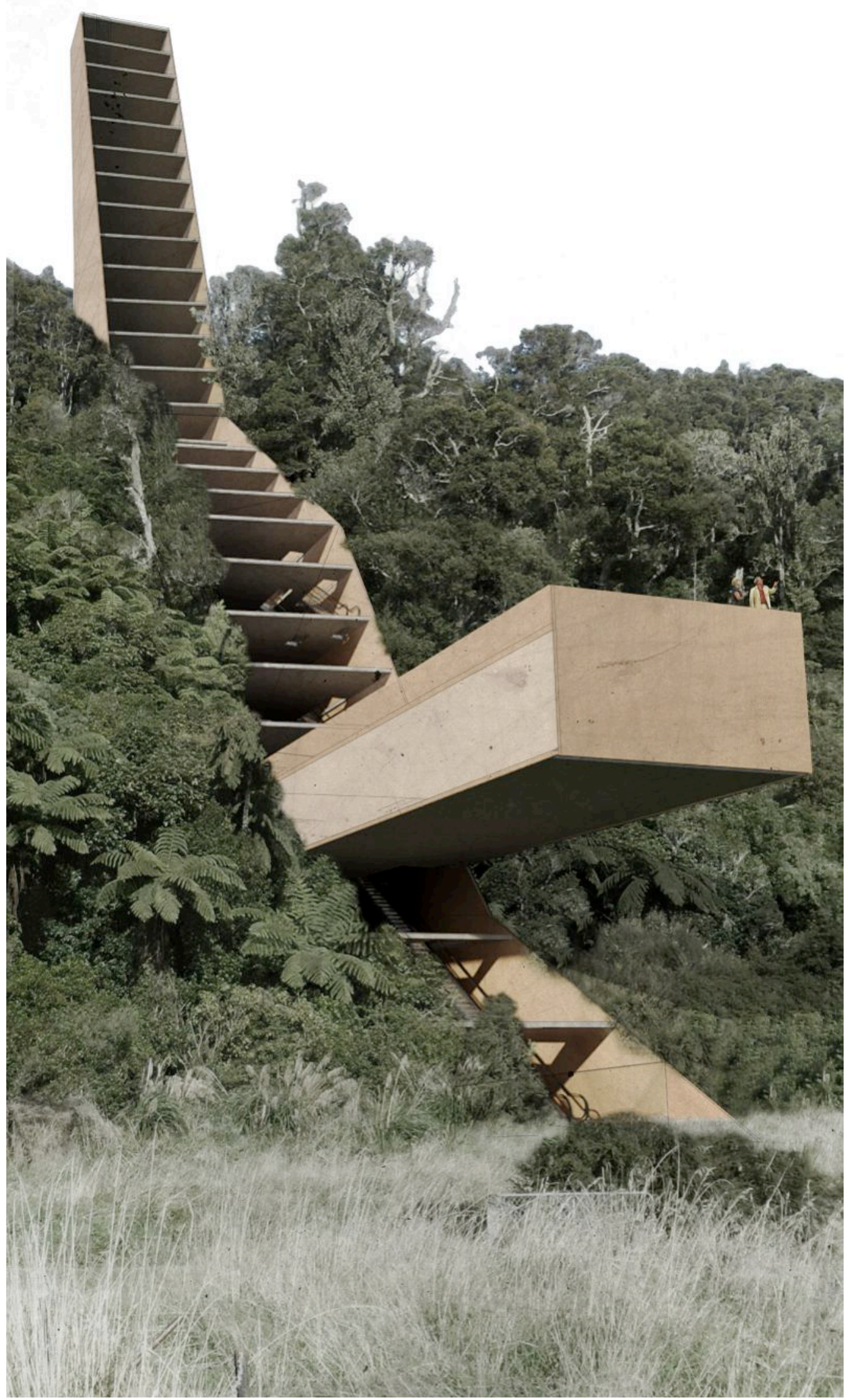

5.12 Occupying the Cut: Replaced Mass 
Occupying the Cut: Replaced Mass

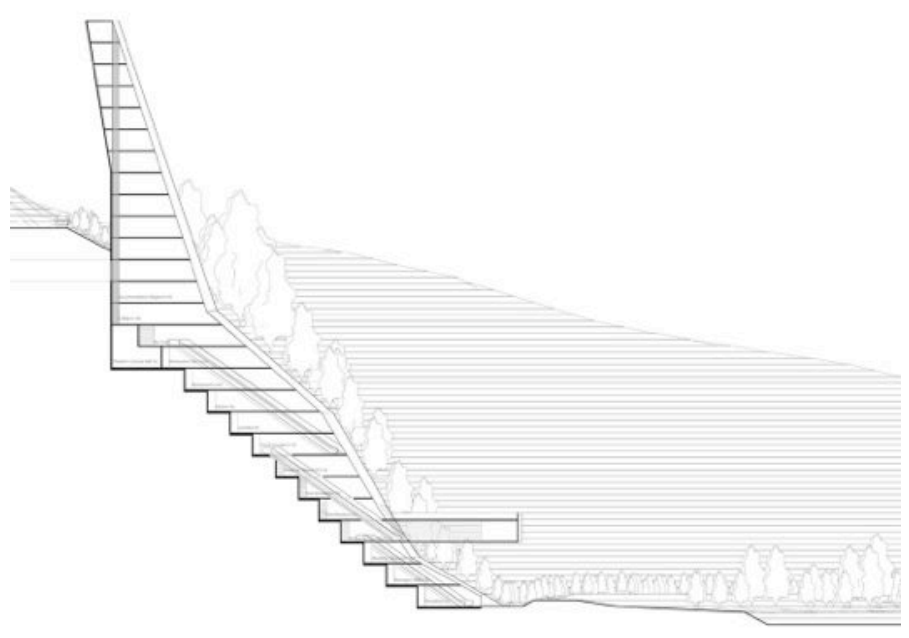

5.13 Occupying the Cut: Replaced Mass Section

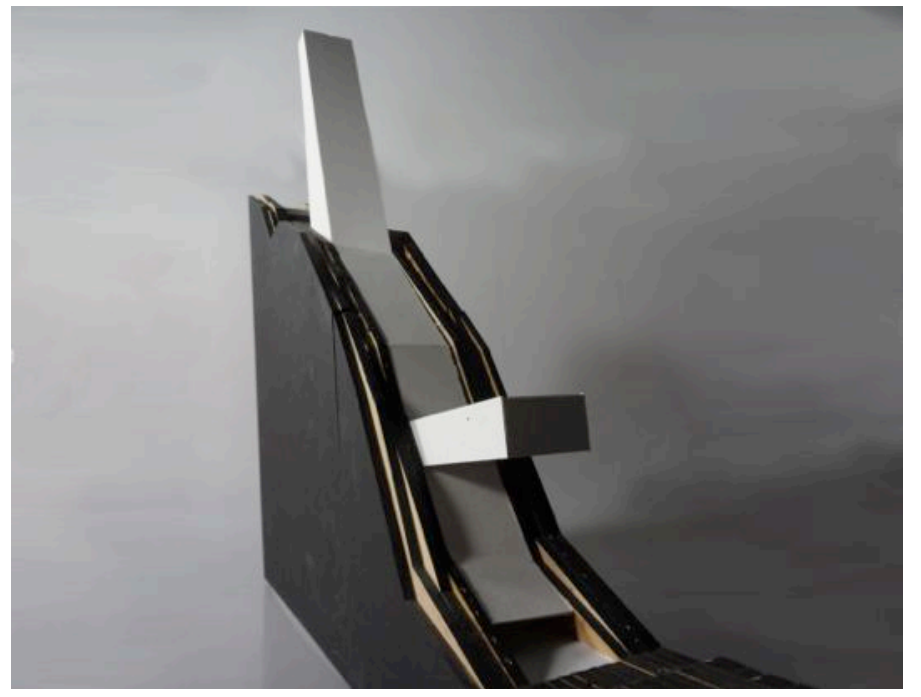

5.14 Occupying the Cut: Replaced Mass Model 1

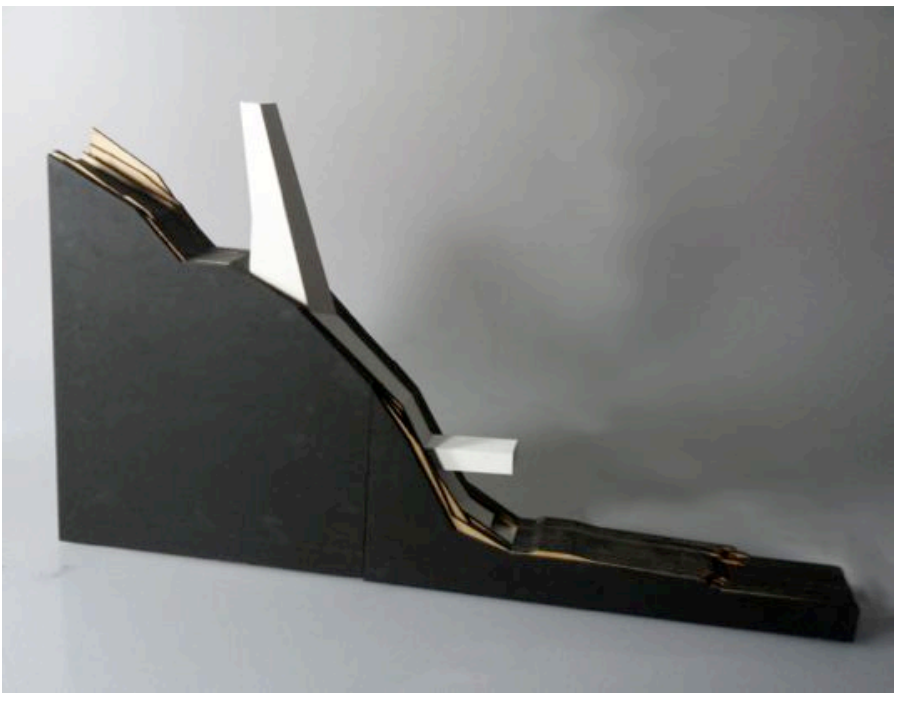

5.15 Occupying the Cut: Replaced Mass Model 2 


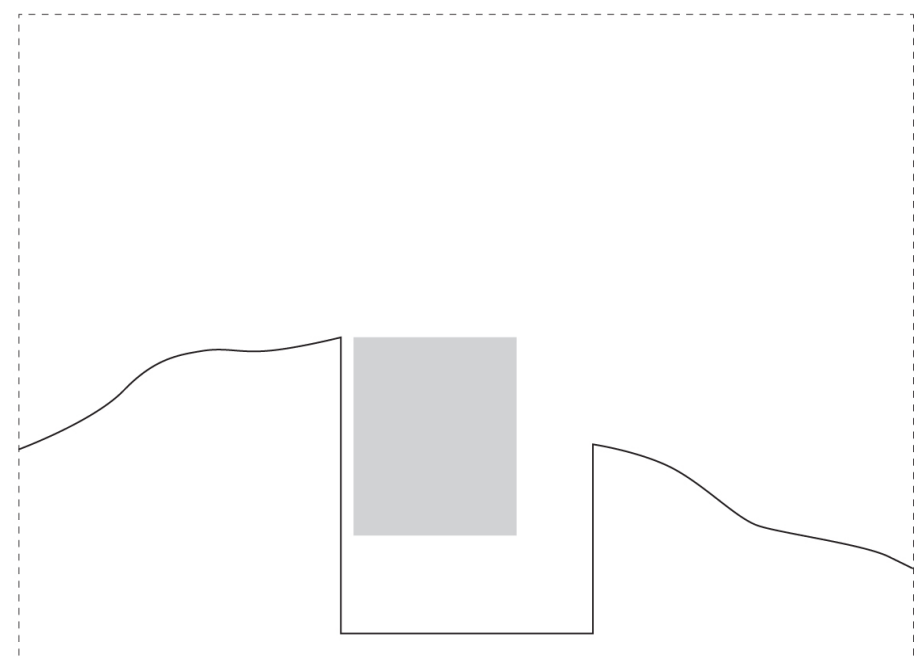

5.16 Occupying the Cut: Displaced Mass

The developed design occupied the cut as an infrastructure of circulation - connecting the road to the lake with a single staircase, with built form raised above. This intervention began to exploit the conditions of the cut, however provided limited natural light and ecological and social views. Housing only 30 people, the scheme was not feasible in response to other high-end resorts or the building footprint. Density, natural light and a heightened engagement with the ecological and cultural cross section would be resolved in the concluding iteration.

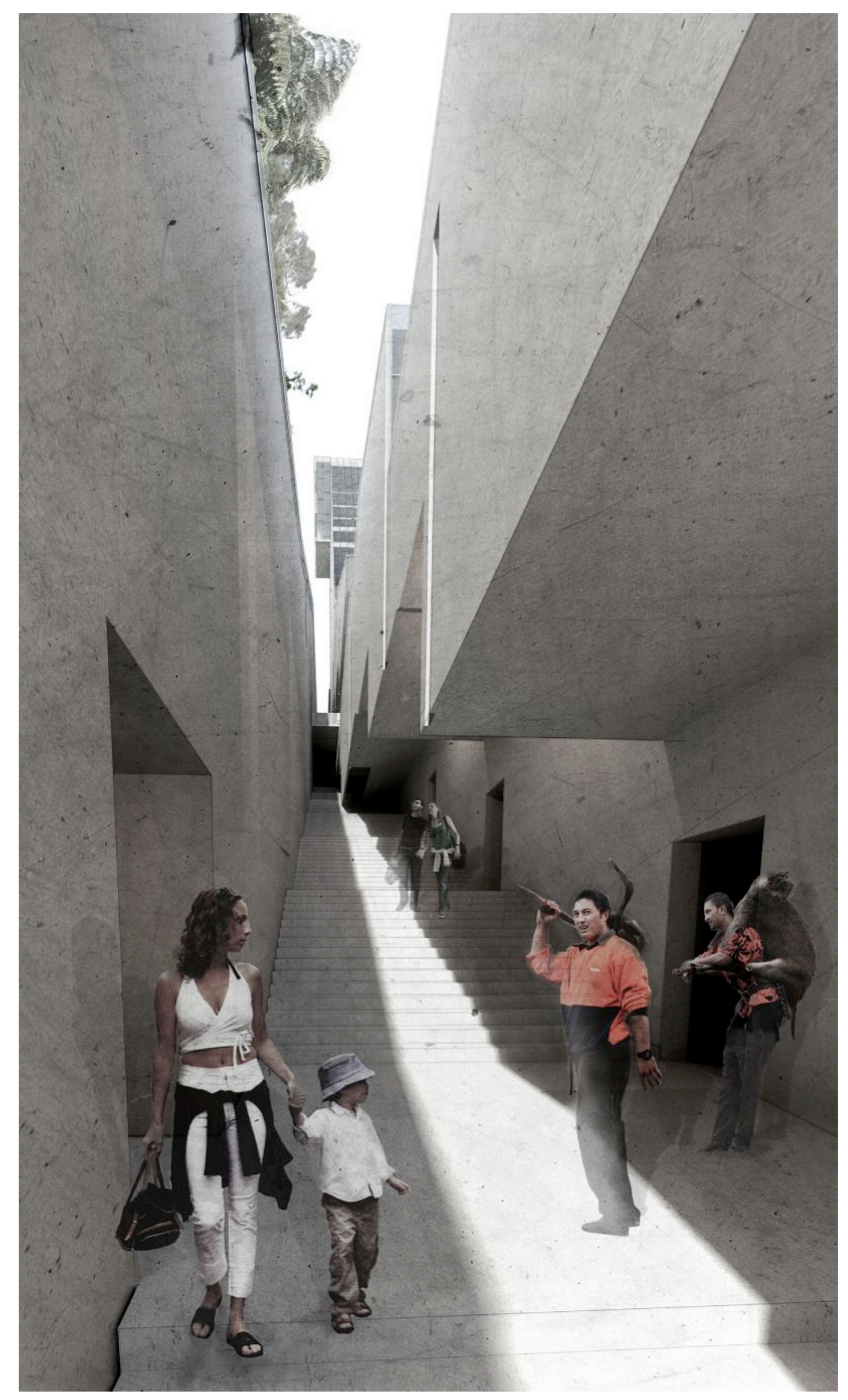

5.17 Occupying the Cut: Displaced Mass 
Occupying the Cut Displaced Mass
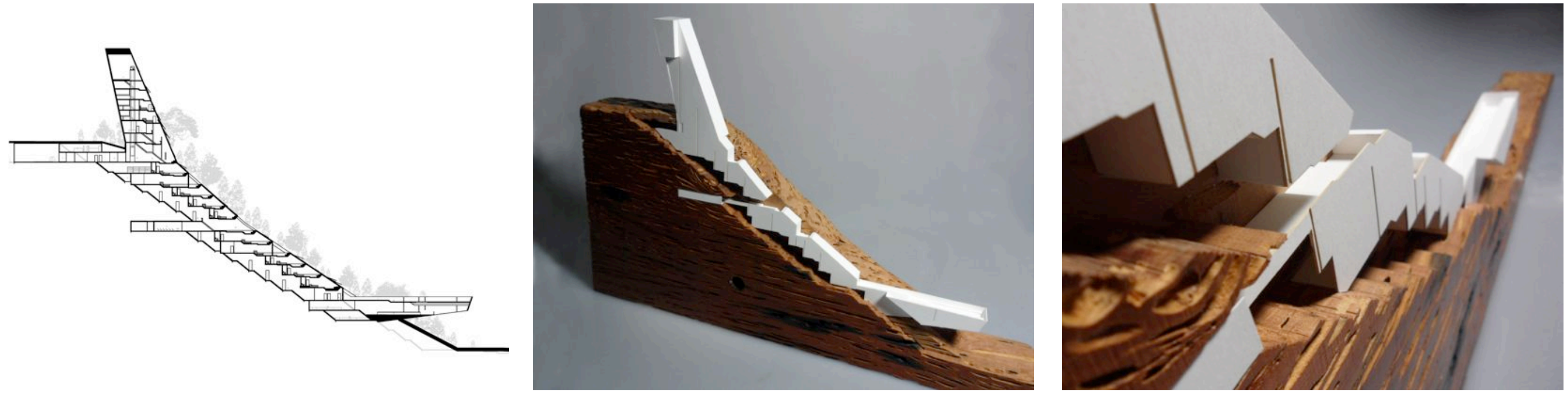

5.18 Occupying the Cut: Displaced Mass Section

5.19 Occupying the Cut: Displaced Mass Model 1

5.20 Occupying the Cut: Displaced Mass Model 2 


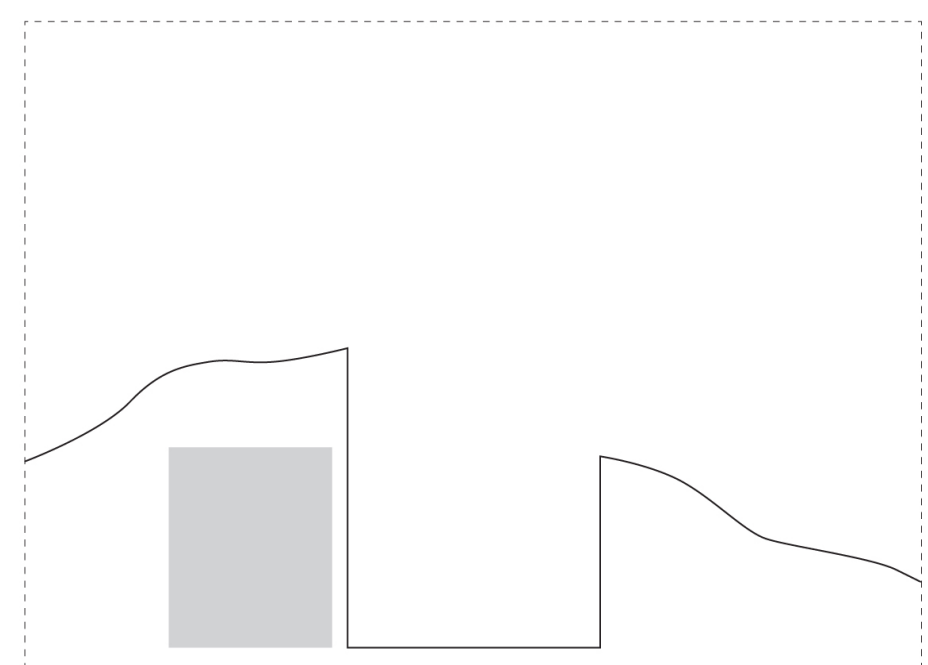

5.21 Occupying the Cut: The Void

The final scheme realizes the spatial conditions of the cut are best exploited when the cut remains void. Providing an open incision in the landscape, issues of natural light and ecological and cultural interactions are resolved. The scheme is a feasible solution, occupying 68 guests - over double the previous scheme and comparable with other high-end resorts (Fig 5.3-5.5). Employing a 'before and after' comparison technique (Fig 5.24-5) throughout the design process has ensured the design outcome strengthens - not weakens - the landscape. Developed further, the scheme would aim to increase density while maintaining the current levels of user comfort (Fig 5.5).

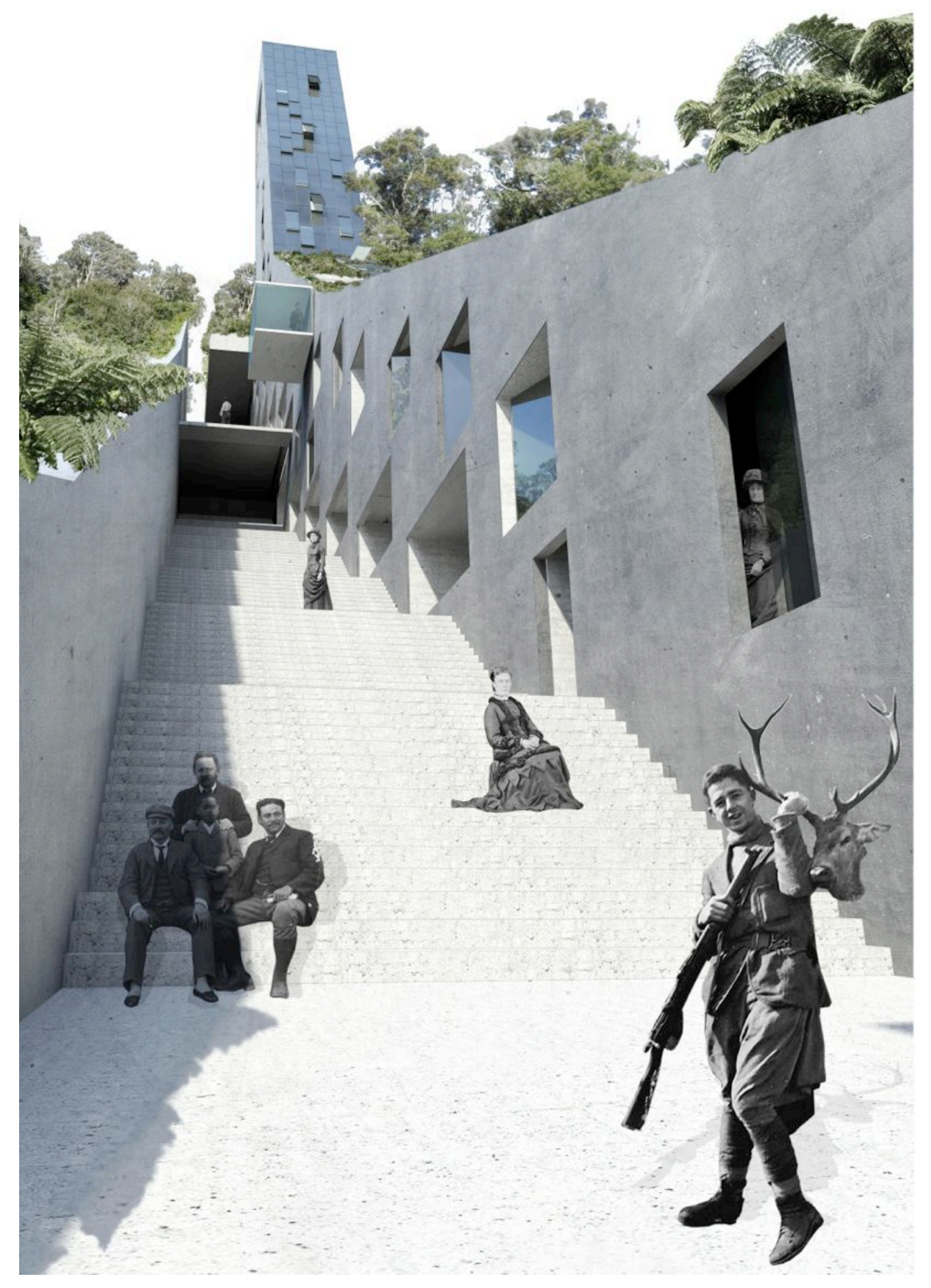

5.22 Occupying the Cut: Looking up cut 
Occupying the Cut: The Void

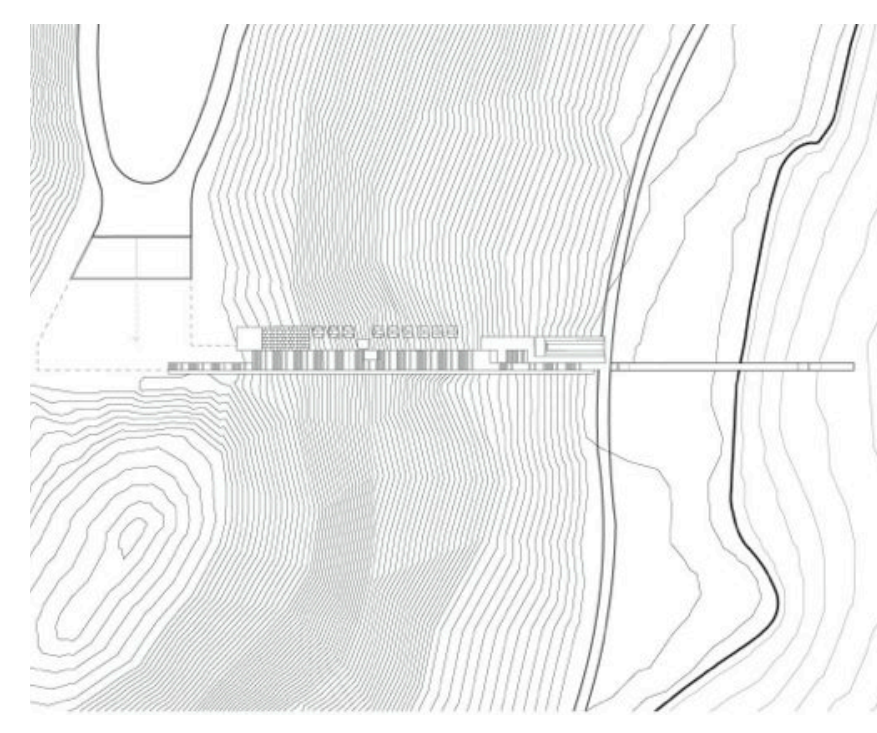

5.23 Scheme Plan

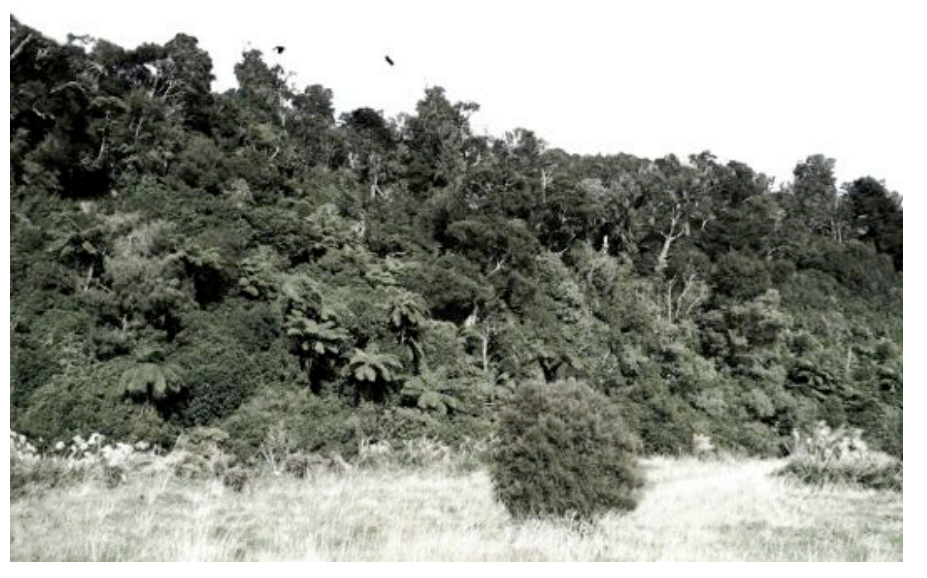

5.24 Before intervention

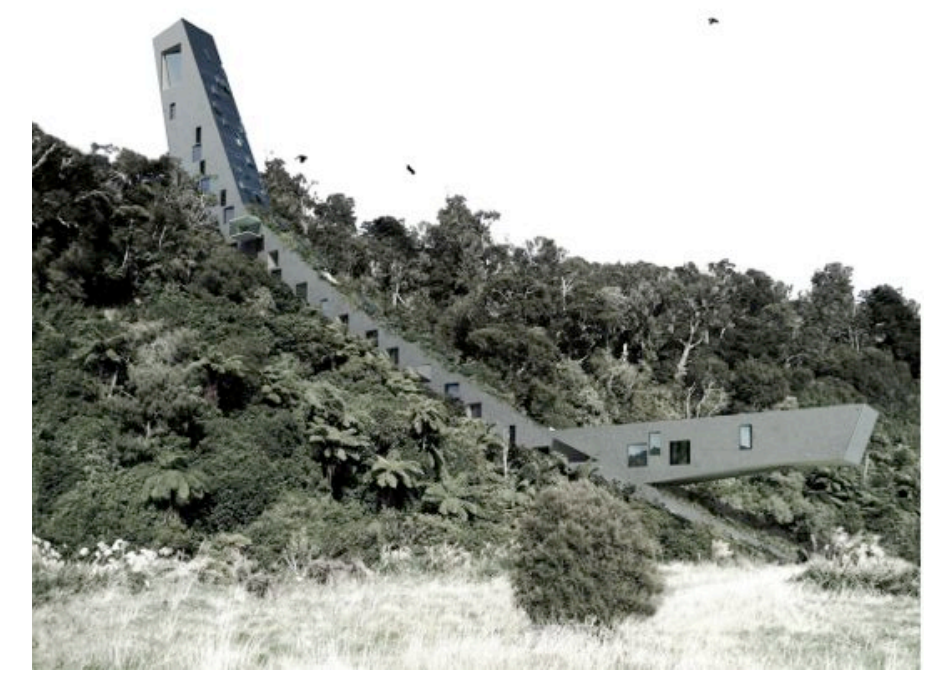

5.25 After Intervention 


.

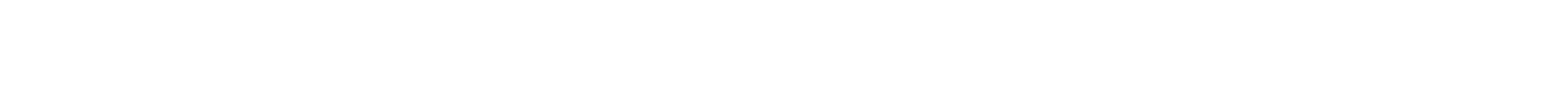

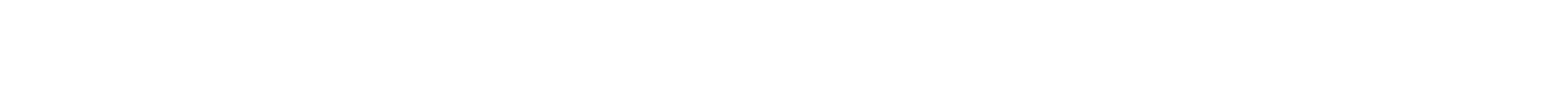


Part Two: The Paper 


\subsection{Problem:}

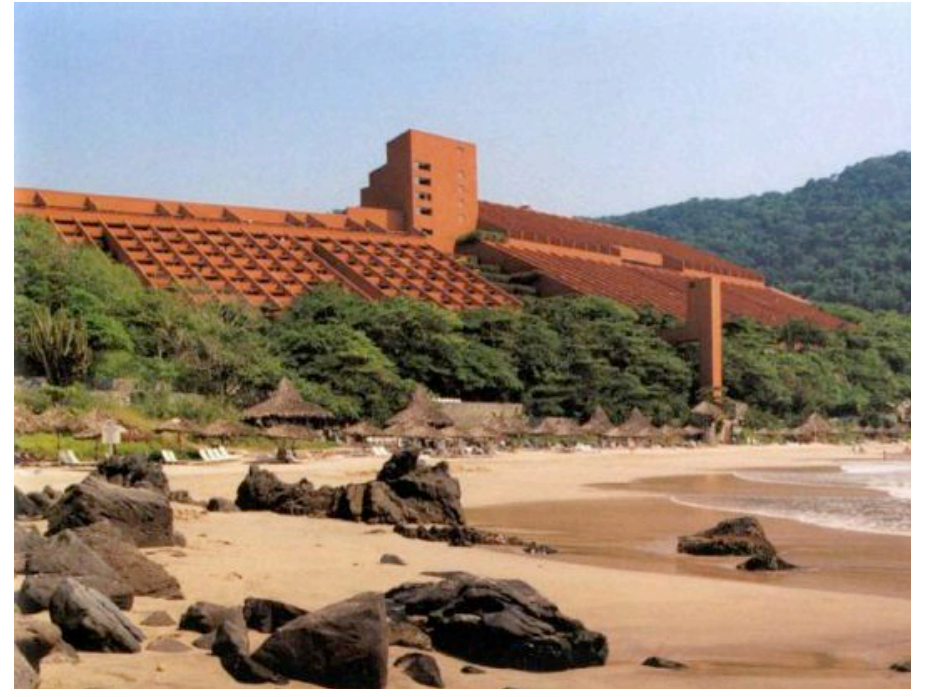

6.1 Richard Legorreta. (1981). Hotel Camino Real. Ixtapa, Mexico.

Retrieved from http://cybertesis.upc.edu.pe/upc/2003/moreyra_as/html/

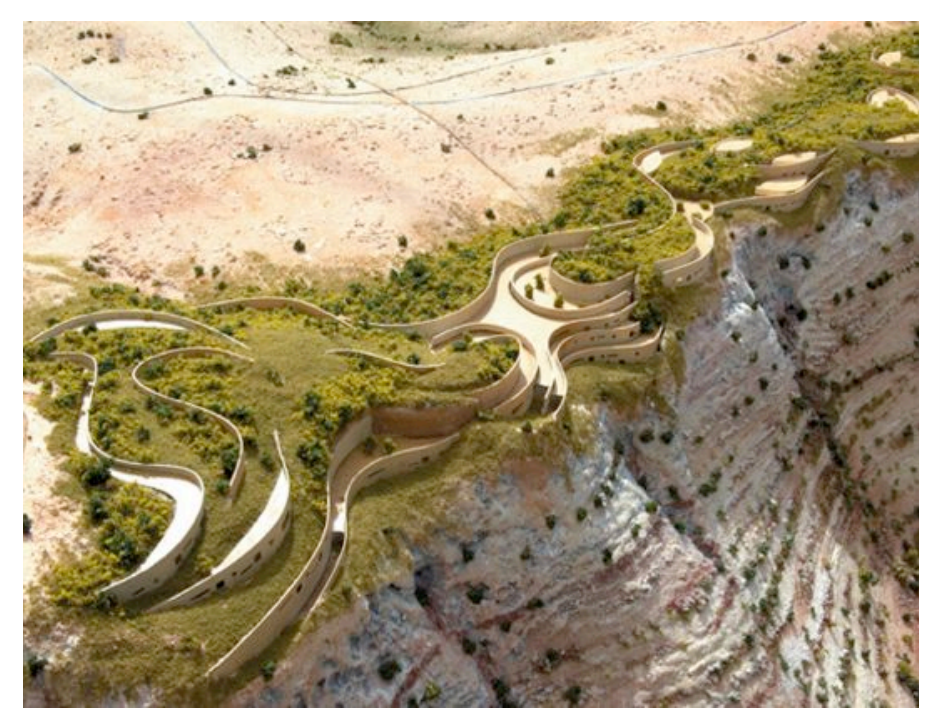

6.2 Foster + Partners. (2005). Green Mountain Canyon Resort. Libya.

Retrieved from http://danielepetteno.com/practice/danielepetteno/experience/collaborationworks/greenmountaincanyonresort.html

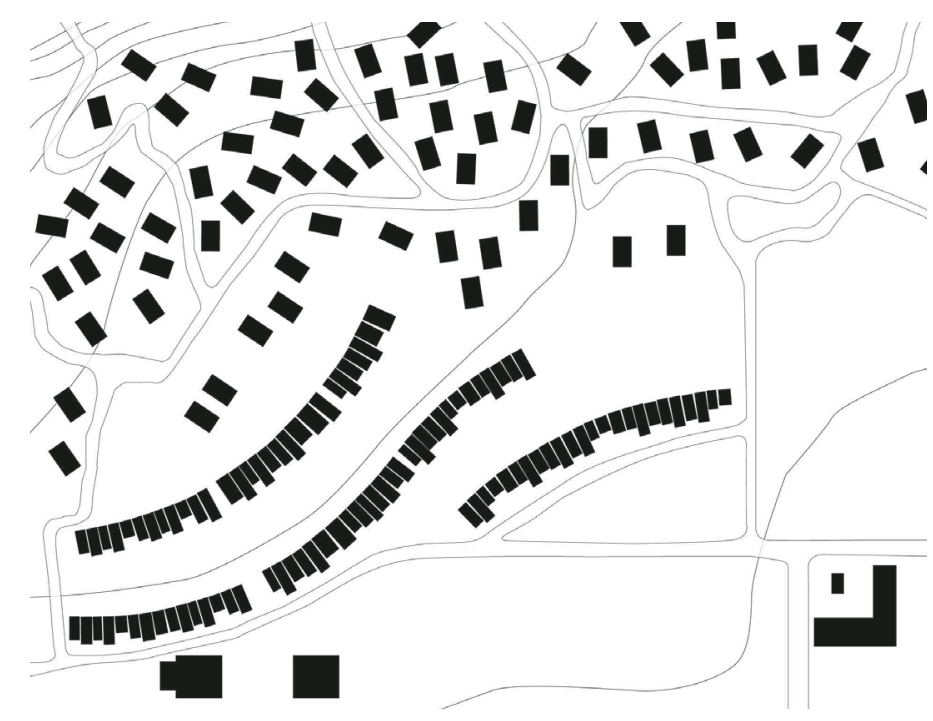

6.3 . Figure/Ground Diagram, King - Rosilli (2007). Club Med Cefalu, Sicily, Italy. 


\subsection{Problem Statement:}

Accommodating large groups of people typically requires large architecture. However, in precious landscapes, such as national parks, large architectural interventions are often opposed on the grounds of an aesthetic cost to the landscape. Within these landscapes, three building types register a number of flawed perspectives.

Firstly, much of the building activity in these landscapes are indifferent to the natural environment - or only tenuously connected - presenting itself much the same as it would in an urban context, or in any other landscape. The architectural language of Richard Legorreta's Hotel Camino Real (1981), Mexico, is a useful example (Fig 6.1). Failing to generate synergy between built form and nature; the dramatic qualities of the landscape, which were presumably there before the building, appear to be reduced by the dominating intervention.

At the other end of the spectrum are buildings that seek camouflage in the landscape through formal mimicry. In an attempt to mitigate aesthetic impact on the landscape, these buildings honour nature through imitation. The Green Mountain Canyon Resort (2005) by Foster + Partners is one such building (Fig 6.2). While this discrete response could be seen as a positive reaction, the ultimate project under these terms is invisible, and the project is not invisible. Inevitably, as no building can be invisible, this is an unproductive direction for the discipline.

More common in tourist areas is the strategy of fragmenting the building into several smaller buildings that are scattered across the landscape in an attempt to minimize the effect of any one building on the landscape. Club Med's village model is a well-established example of this approach (Fig 6.3), and while it does not rely on formal mimicry, the ideal of this strategy is also reduced visibility. Intent on mitigating aesthetic damage, this strategy fails to enhance the landscape, often resulting in rural sprawl and a self-destructive miniaturization of the landscape.

The high-end resort typology would require a relatively large footprint and would suffer the same critique as the approaches noted above. 


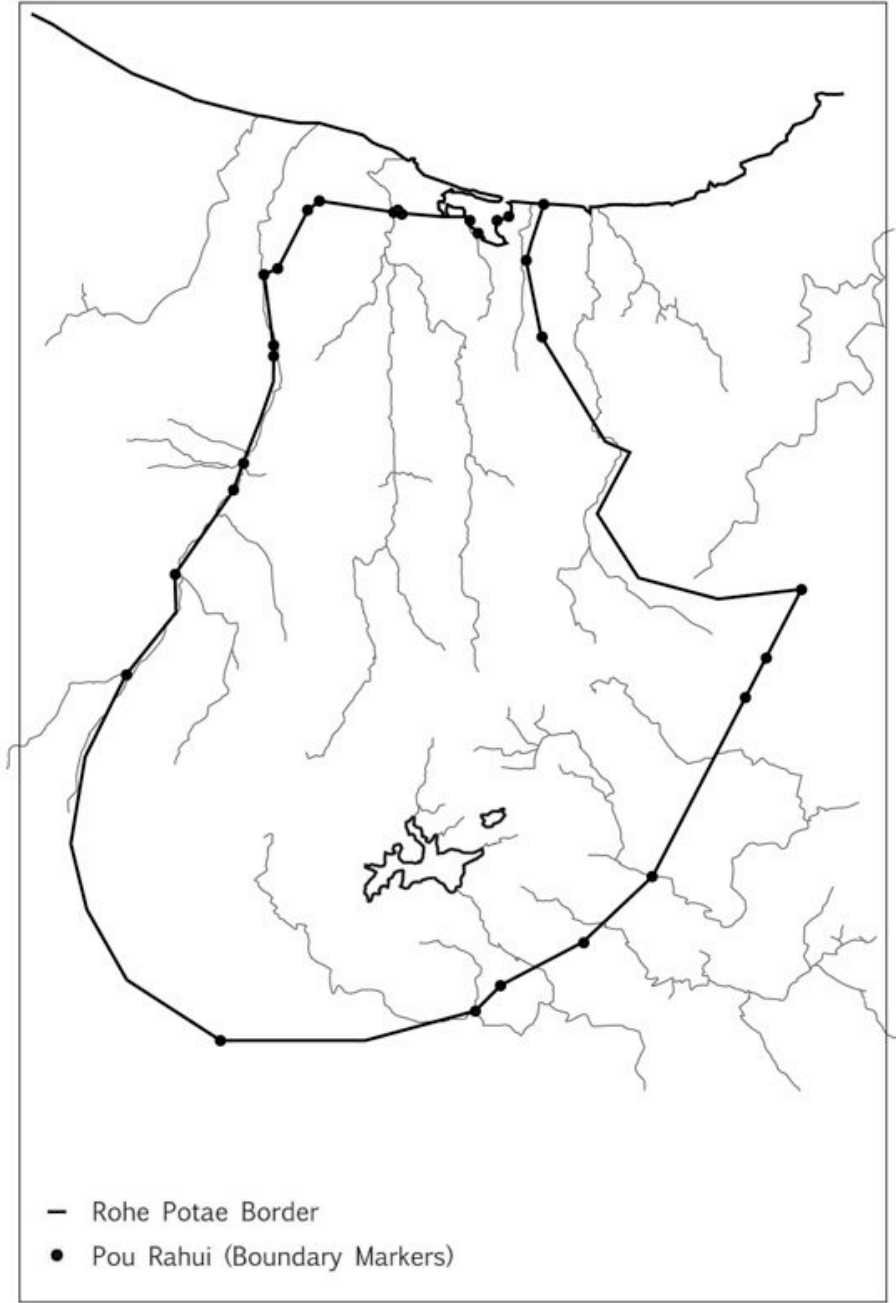

6.4 1865: Tūhoe's Rohe Potae Border

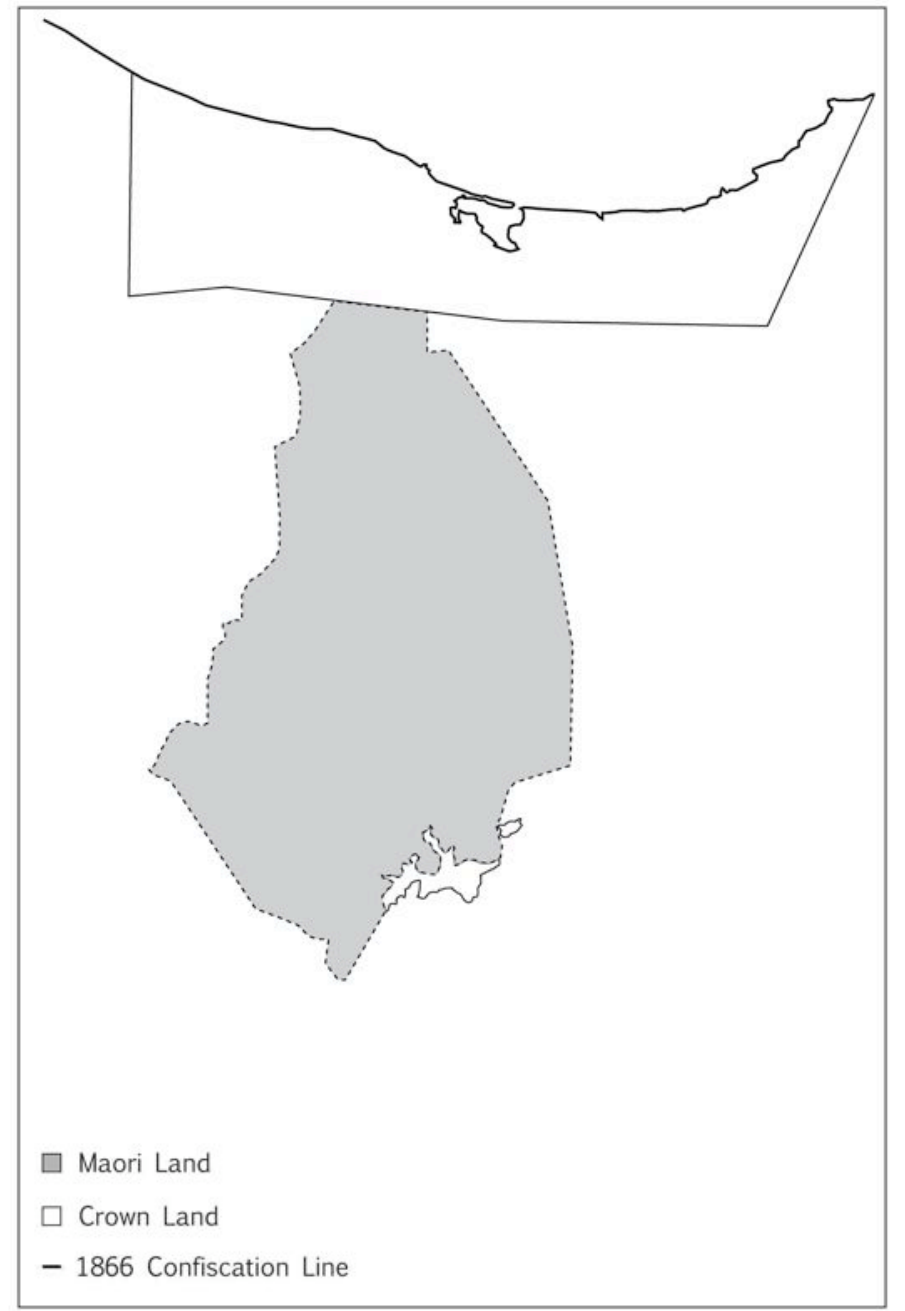

6.5 1910: The Urewera District Native Reserve

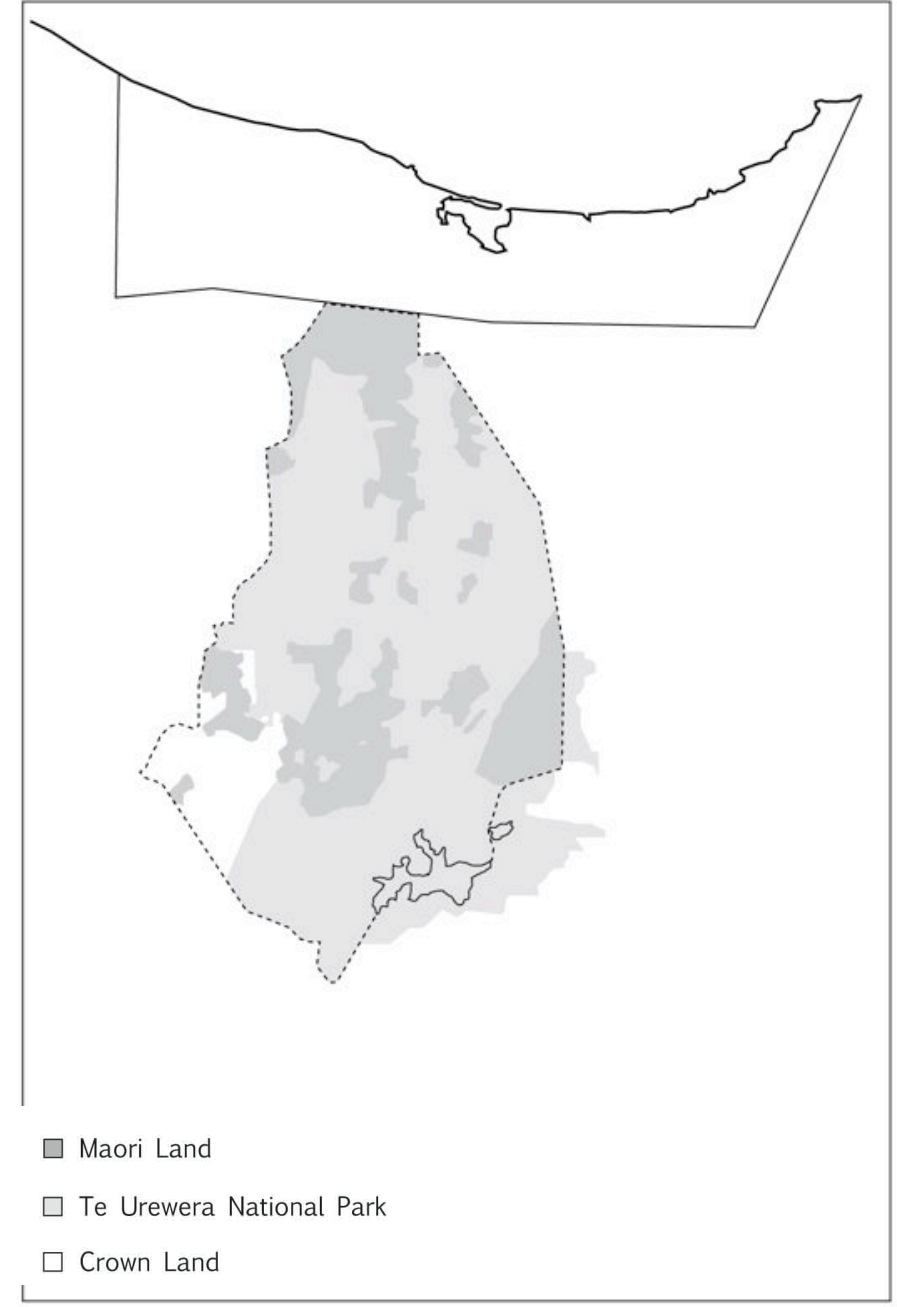

6.6 2012: Te Urewera National Park 
Geoff Park (2007) localizes this problem, identifying several cultural issues facing the "occupation" of New Zealand's precious and contested landscapes. Through the conservation movement, Park (2007, p.202) identifies that New Zealand was either protected as indigenous or developed as not, with no attempts to progress a "middle landscape" of both people and indigenous life. Employing the Western national park model (Park, 2001, p.333), management of these precious landscapes continues to imply that people and nature are somehow incompatible. Within Te Urewera National Park, the spiritual homeland of the Tūhoe people (Wood, 2000, p. 219), this attitude has dramatically affected how land is occupied. In just over a century, Tūhoe have diminished from the only autonomous tribal district ever recognized in New Zealand law (Binney, 2009, p.179) to a widely dispersed people owning less than 11 percent of their original land (Campbell, 1999, p.156). Today, land confiscation, consolidation schemes, leases, purchases and national park legislation ensure that only three individuals live within the 212,672ha park boundary (Fig 6.4-6). ${ }^{1}$ Revealing the Māori-Pakeha divide at its sharpest, this matter of land occupation has generated a deep dissonance between Tūhoe and the Crown (Binney, 1995).

On September 11, 2012, following 160 years of negotiation, Tūhoe negotiators agreed to settle the tribe's grievances with the Crown, gaining shared management of Te Urewera National Park - opening up the possibility of new settlements "right up in the middle of $\mathrm{Te}$ Urewera." (Tahana, 2012) Providing a unique opportunity to rethink how we may occupy a middle landscape, Te Urewera National Park offers a productive landscape to reconsider these formal and cultural problems.

\subsection{Research Question:}

What strategies do architects need to take to develop large buildings in the landscape that are neither invisible nor an aesthetic expense, but rather enhance the landscape such that it is more intelligible, more spectacular or more dramatic? 


\subsection{Proof of Problem:}

A re-constructed before (current) and after (removing the building) comparison technique has been employed to determine whether the formal responses enhance or detract from the landscape.

\subsection{Unresponsive to Landscape:}

The first problematic strategy involves buildings that are largely unresponsive to the natural environment. In Hotel Camino Real, the building overpowers the dramatic landscape (Fig 7.1-3). Not out of place in an urban environment, the extruded mat form - revealed most clearly in plan - lacks any dialogue with the landscape. The Hermitage Hotel (1957) can be positioned alongside this intervention as a dominating building largely unresponsive to its spectacular environment (Fig 7.46). This local example contains a sprawling and incoherent range of buildings that fail to strengthen the unique qualities of the landscape. Located on the boundary of the treaty grounds at Waitangi, the Copthorne Hotel (1962) also offers no added value to the landscape (Fig 7.7-9). Interchangeable with any other Copthorne Hotel building, this example has been identified for its lack of cultural consideration. While not restricted to sensitive formal responses, architecture within cherished landscapes should not be interchangeable with buildings from less spectacular sites, but should be as valued as the landscape it sits within. 


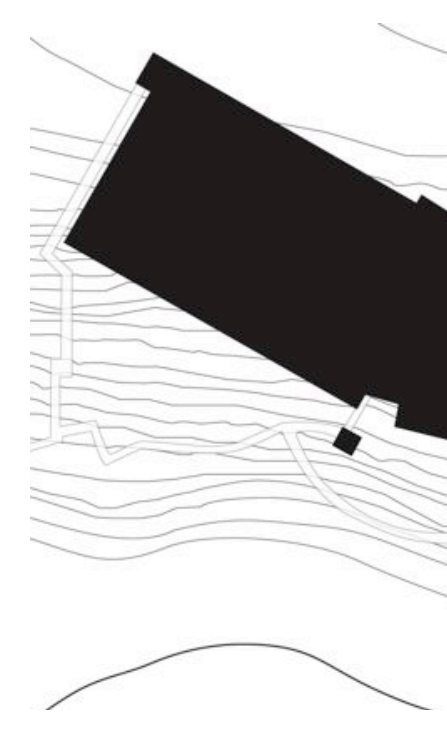

7.1 Figure/Ground

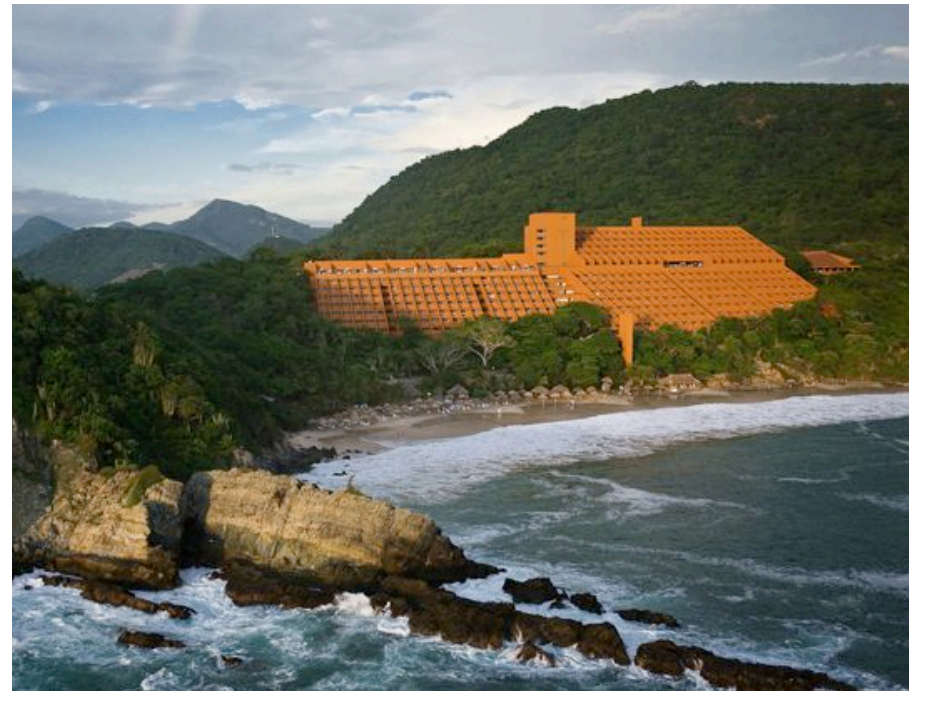

0
7.2 Before Retrieved from http://flickr.com/photos/erick_m_photo/6603968255/in/
photostream

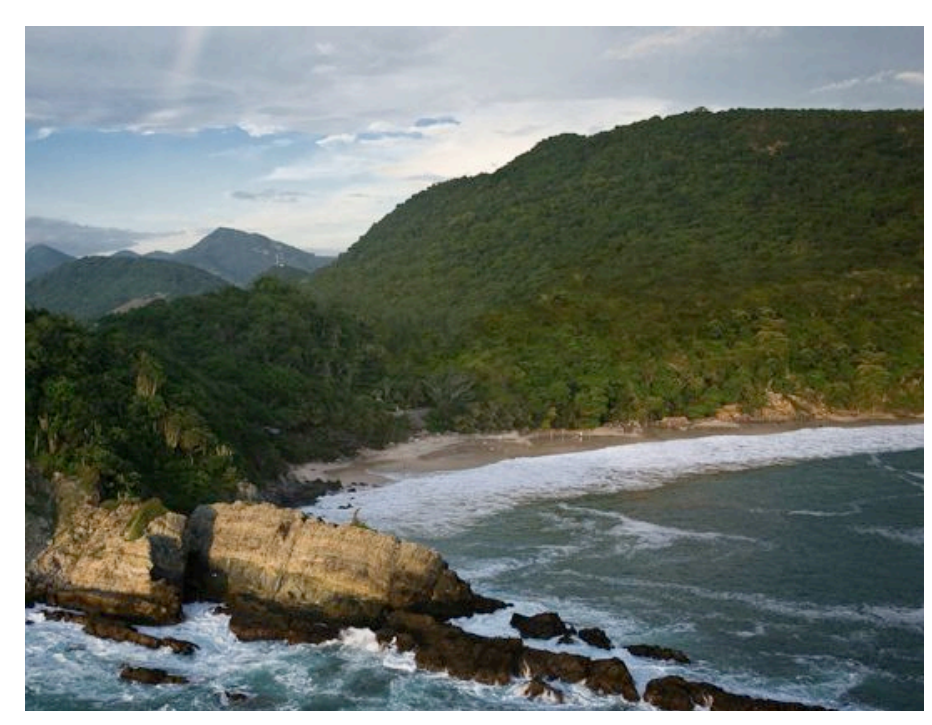

7.3 After

Edited by author from http://flickr.com/photos/erick_m photo/6603 968255/ inphotostrean

1981, Richard Legorreta, Hotel Camino Real, Ixtapa, Mexico. 


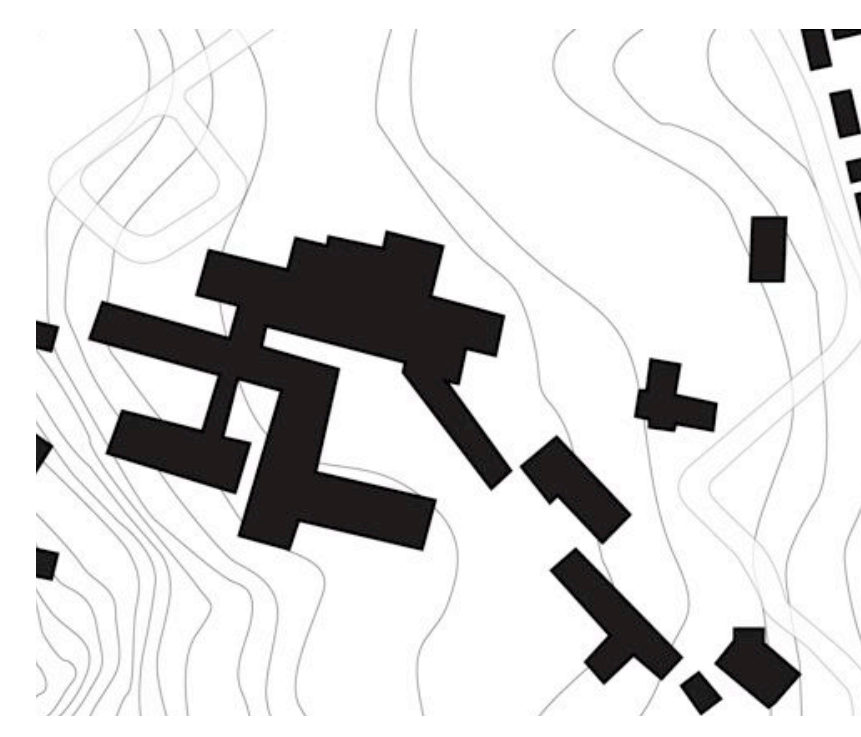

7.4 Figure/Ground

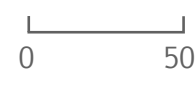

50

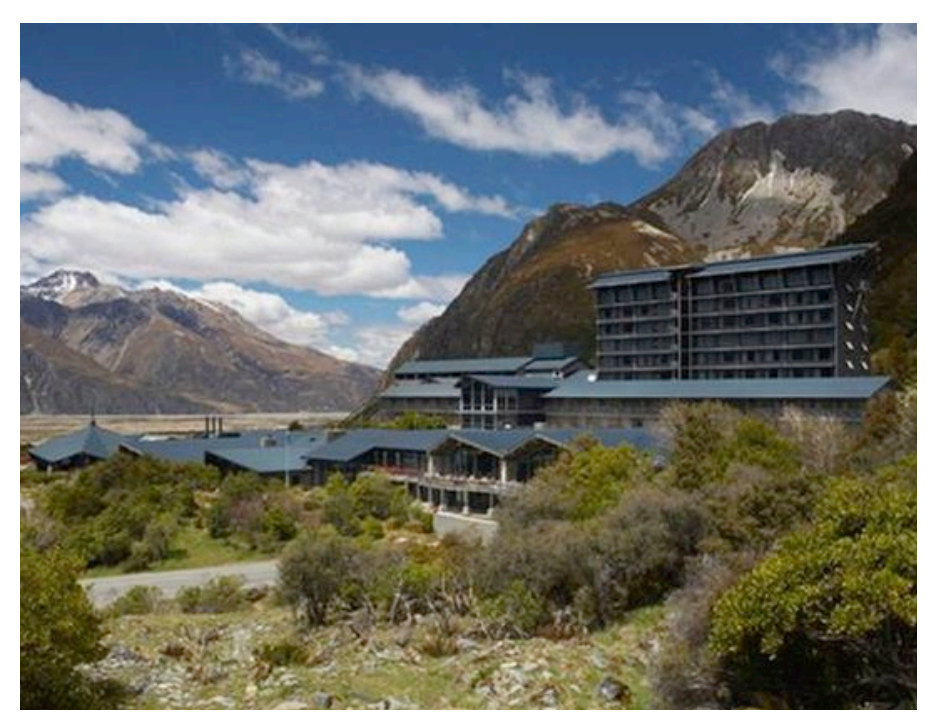

7.5 Before

Retrieved from http://hermitage.co.nz/en/trade-and-media

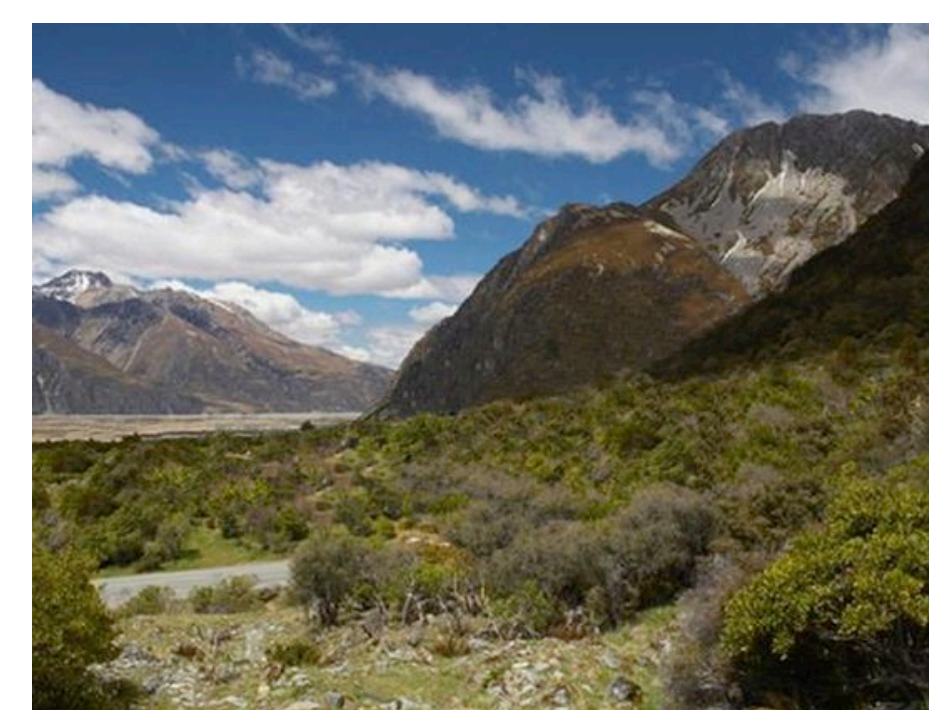

7.6 After

Edited by author from http://hermitage.co.nz/en/trade-and-media 


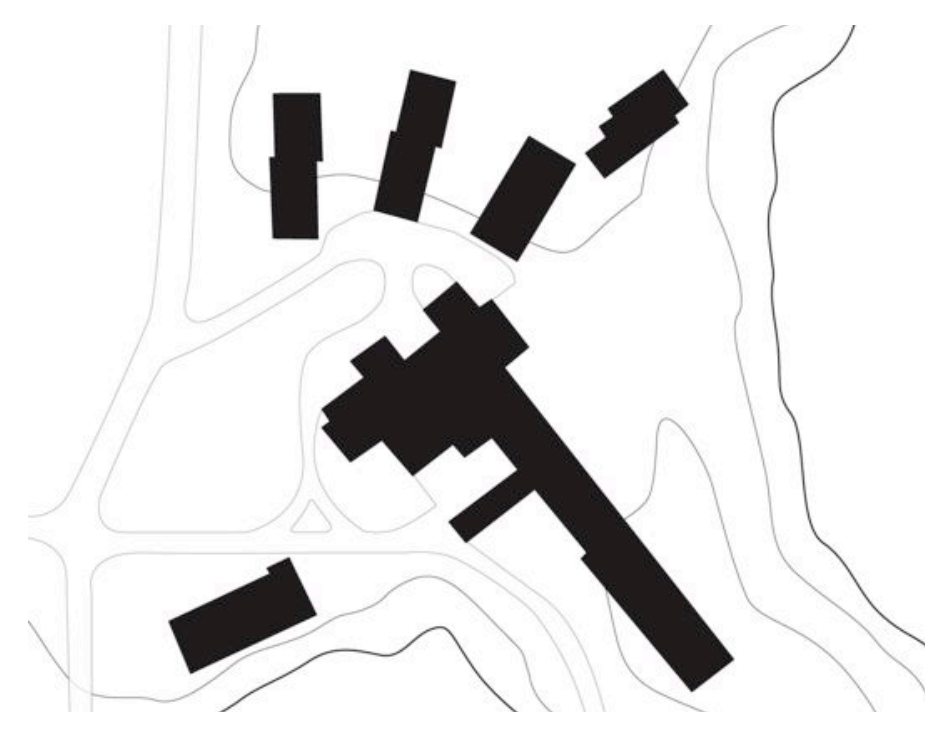

7.7 Figure/Ground

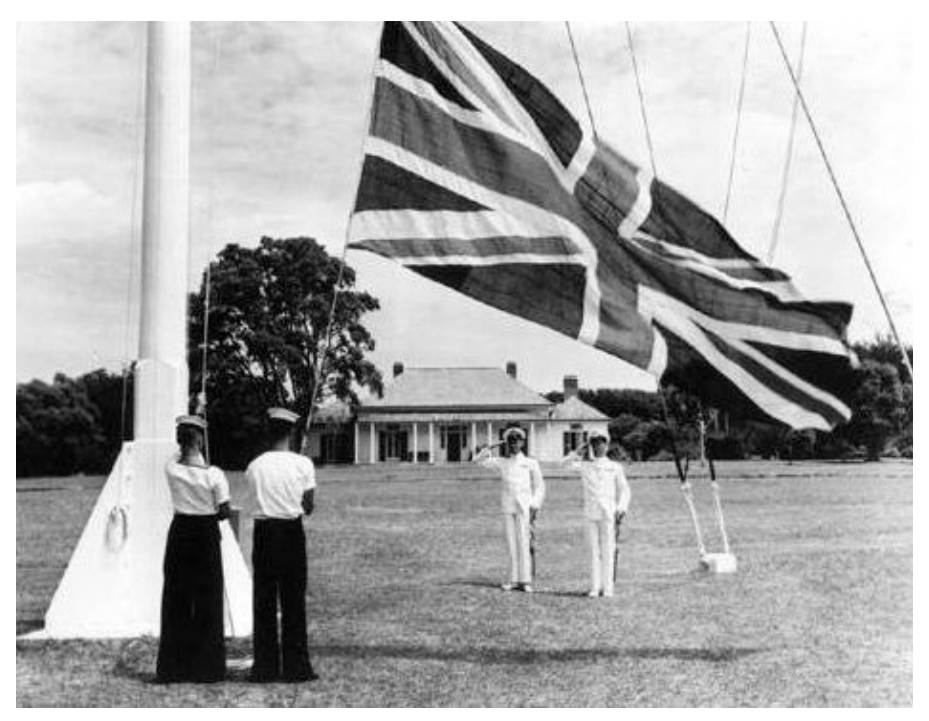

(1) 7.8 Hallen, A. (1833). Treaty House, Waitangi, New Zealand.

Retrieved from http://cosgrove.school.nz/nzthings.html

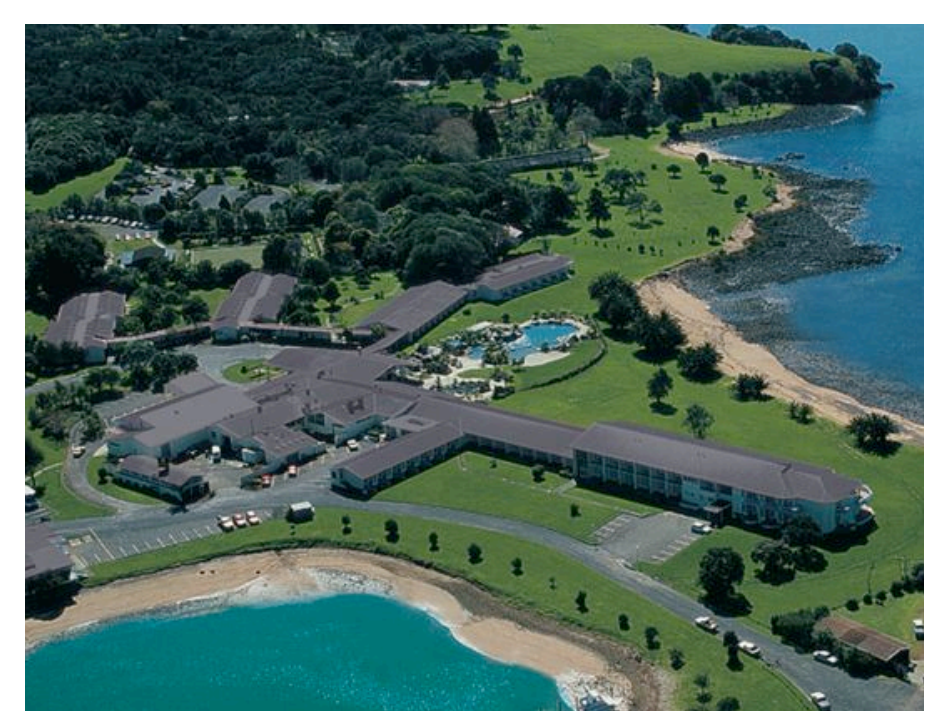

7.9 Architect Unknown. (1962). Copthorne Hotel, Waitangi, New Zealand.

Retrieved from http://moatrek.co.nz/tours/northland/

1962, Architect Unknown, Copthorne Hotel, Waitangi, New Zealand. 


\subsection{Formal Mimicry:}

The second strategy employs formal mimicry, in an attempt to mitigate aesthetic impact on the landscape. The Green Mountain Canyon Resort exercises this technique, attempting to disappear as to not detract from the natural spectacle of the cliff faces (Fig 7.10-12). As the ultimate project under these terms is invisible - and as the project is not invisible - it seems an unproductive direction for the discipline. Alternatively, the success of the project could be measured through the dialogue between the architecture and the cliff. But then, we would expect the architecture to enter into a dialogue with the cliffs where each was made more spectacular by the other, and there is no architectural gesture that achieves that. This reaffirms that architecture should be more markedly different from the landscape. 

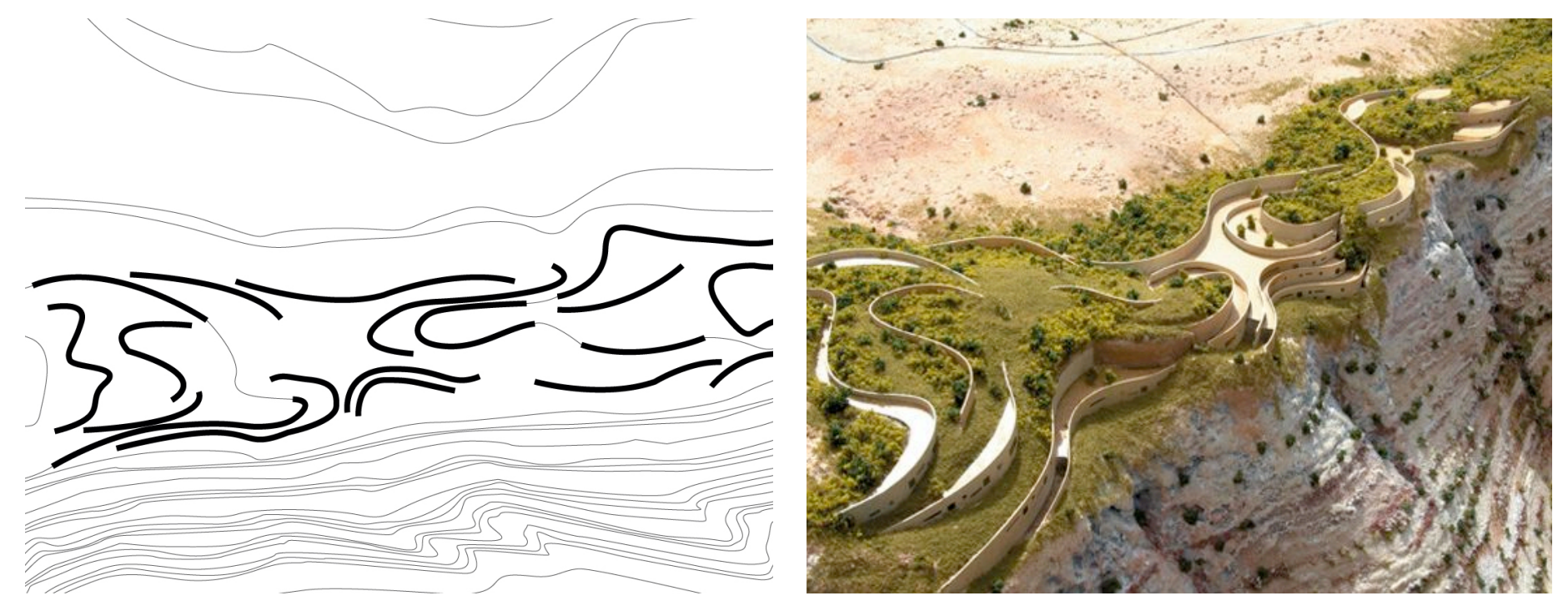

7.10 Figure/Ground

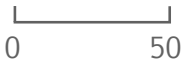

(1)

7.11 Before

Retrieved from http://danielepetteno.com/practice/danielepetteno/experience/collaborationworks/greenmountaincanyonresort.html

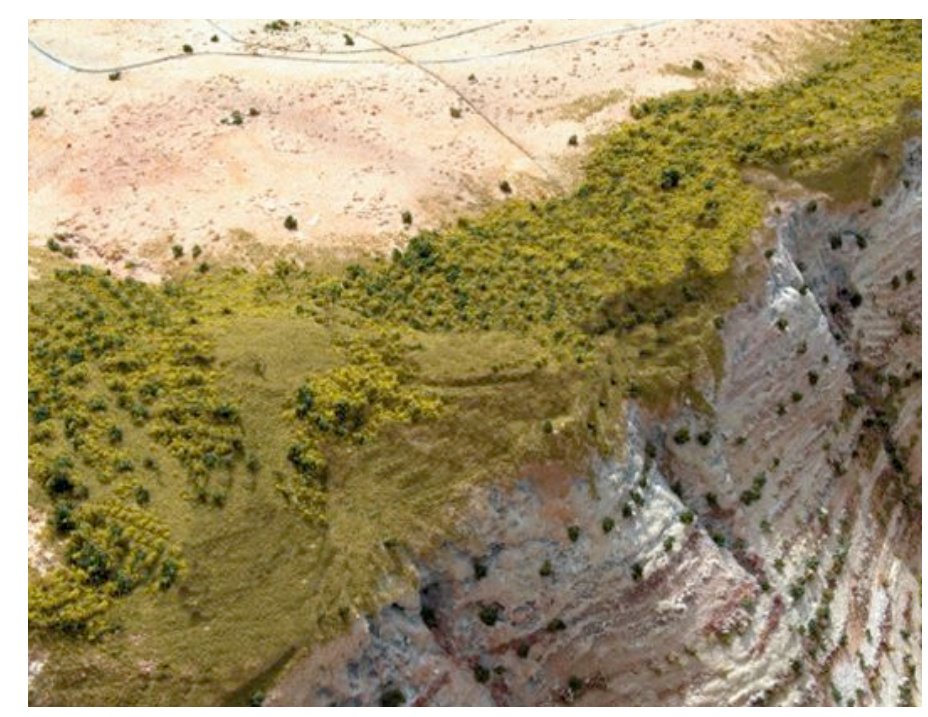

\subsection{After}

Edited by author from http://danielepetteno.com/practice/danielepetteno/ experience/collaborationworks/greenmountaincanyonresort.html 


\subsection{Formal Dilution:}

The third strategy reduces the scale of the buildings and disperses them throughout the landscape to minimize the effect of any one building in the landscape. King - Roselli's Club Med Cefalu (2007) is a useful example that employs this fragmented village model (7.1315). Creating a self-destructive miniaturization of the landscape, the rural sprawl can be identified most alarmingly in plan. While more restrained and sensitive in its execution, Graciastudio's Endémico Resguardo Silvestre (2011) also fails to enhance the landscape (Fig 7.16-18). The landscape, now full of small things, is drained of its scale and emptiness. The Millbrook Resort Villas (1993-2012) form a local example of this sprawling type, exacerbated by the approach to domesticate the landscape (Fig 7.19-21). Satisfying a rising demand for private real-estate property in tourism destinations (Bekirogle \& Gipser, 2008), the villa resort appears out of its urban context and offers no added value to the landscape. 


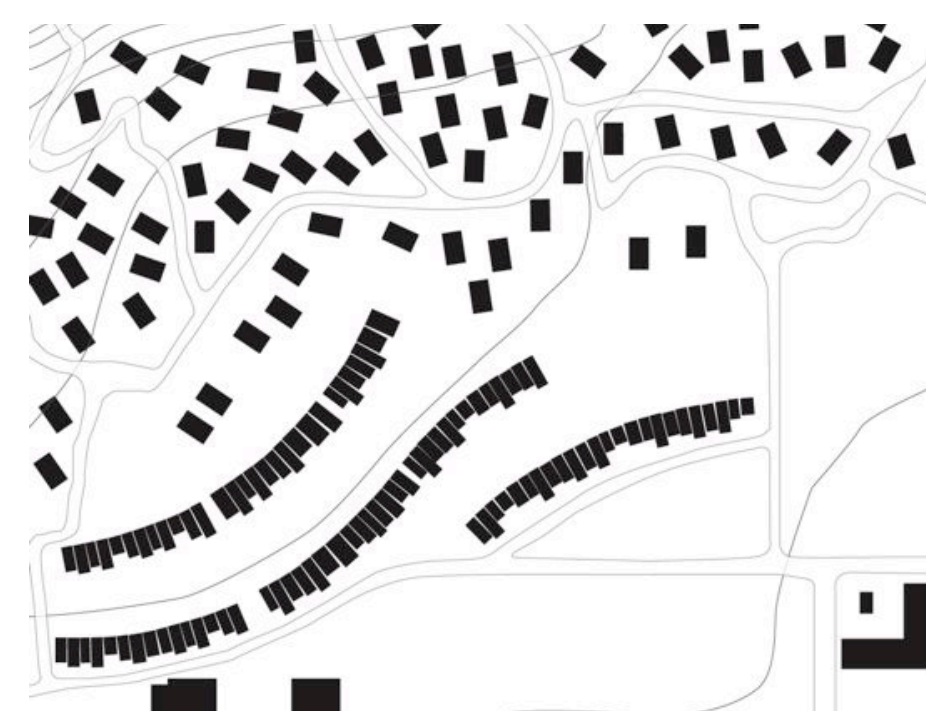

7.13 Figure/Ground

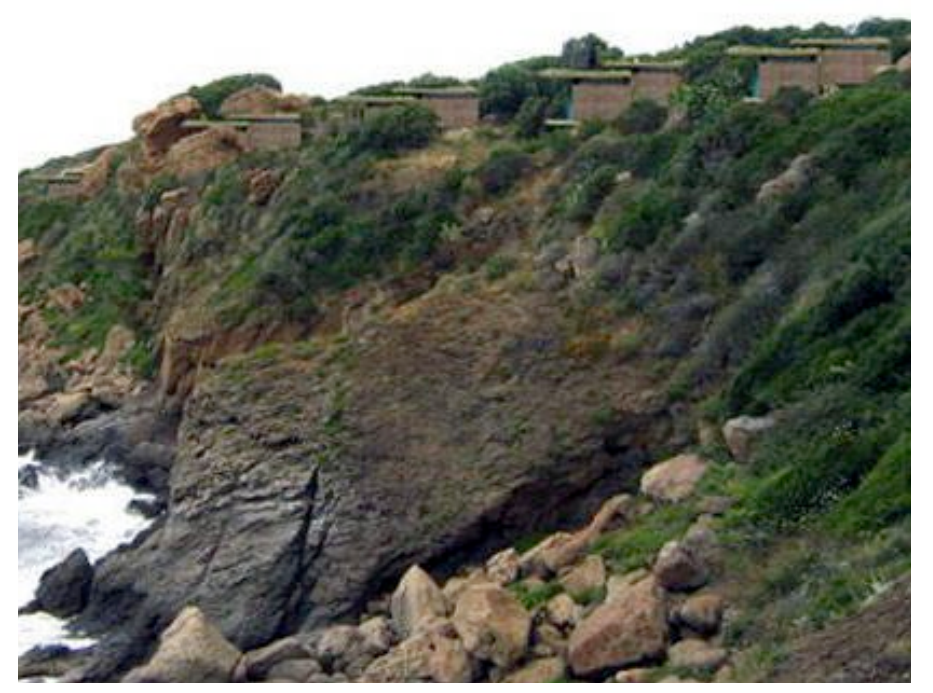

7.14 Before

Retrieved from: http://europaconcorsi.com/projects/1874-Club-Med-Cefal-/

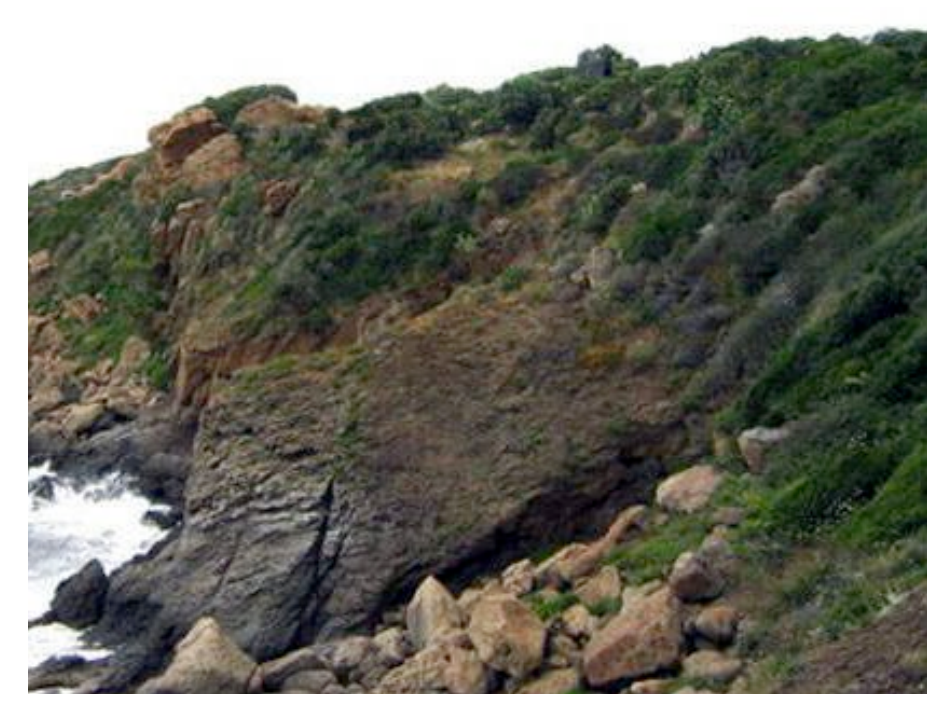

7.15 After

Edited by author from: http://europaconcorsi.com/projects/1874-Club-MedCefal-/print

2007, King - Roselli, Club Med Cefalu, Sicily, Italy. 


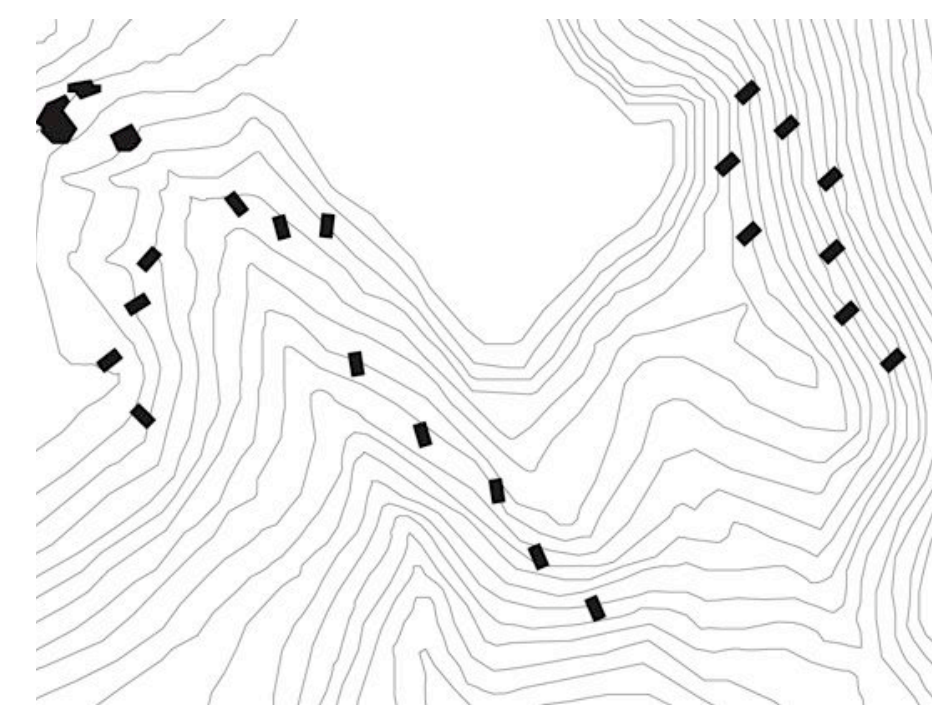

7.16 Figure/Ground

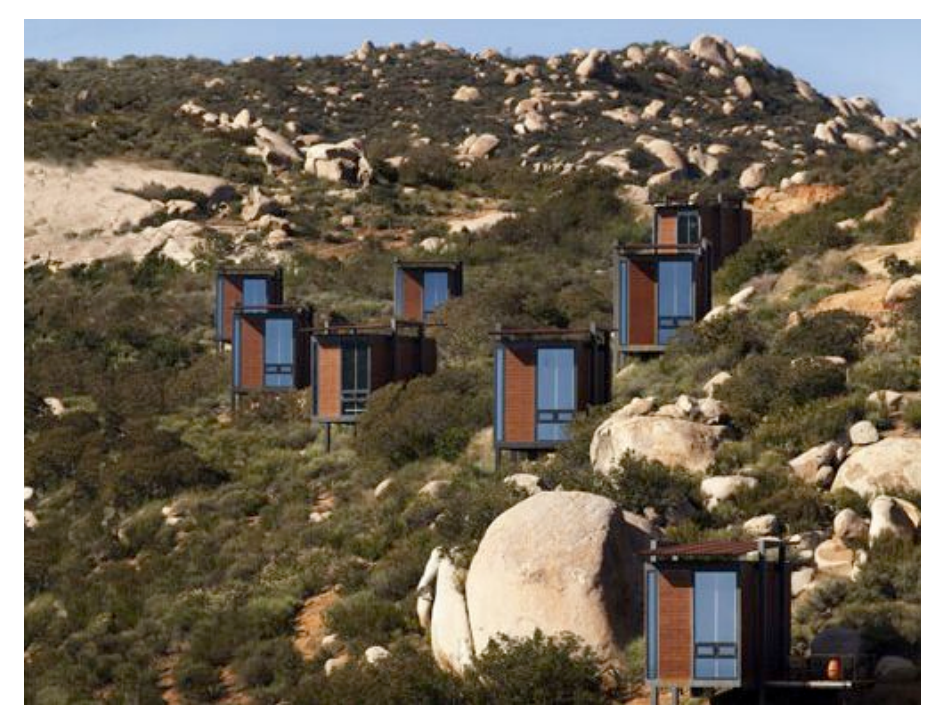

7.17 Before

$\begin{aligned} & \text { Retrieved from http://graciastudio.com/Projects/Comercial/Endemico/ } \\ & \text { endemico.html }\end{aligned}$

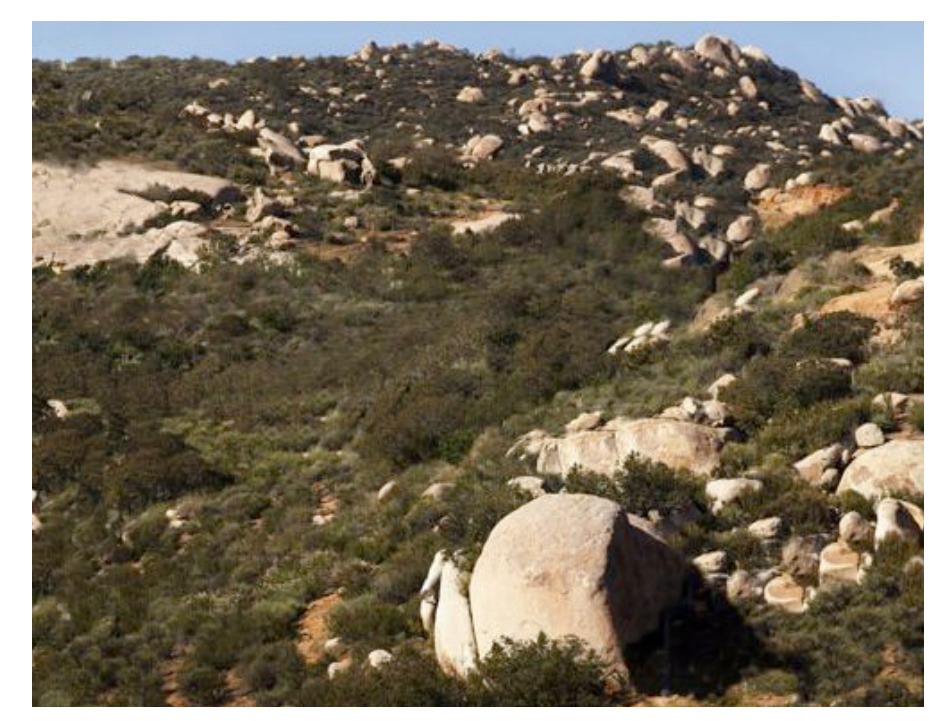

7.18 After

Edited by author from http://graciastudio.com/Projects/Comercial/Endemico/endemico.html 


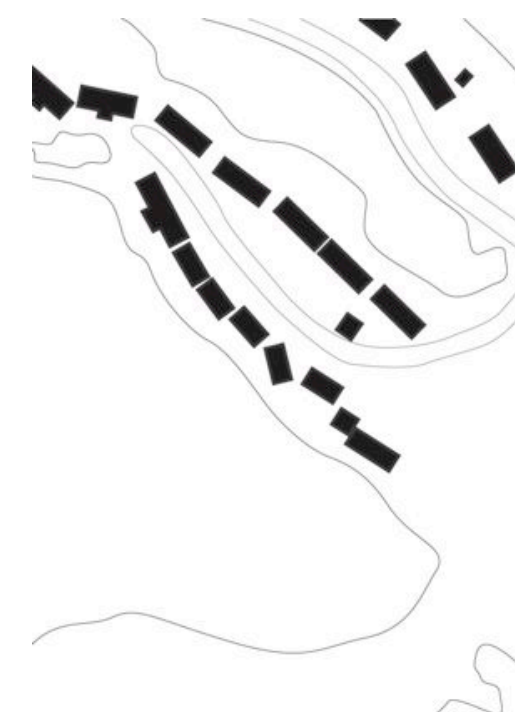

7.19 Figure/Ground

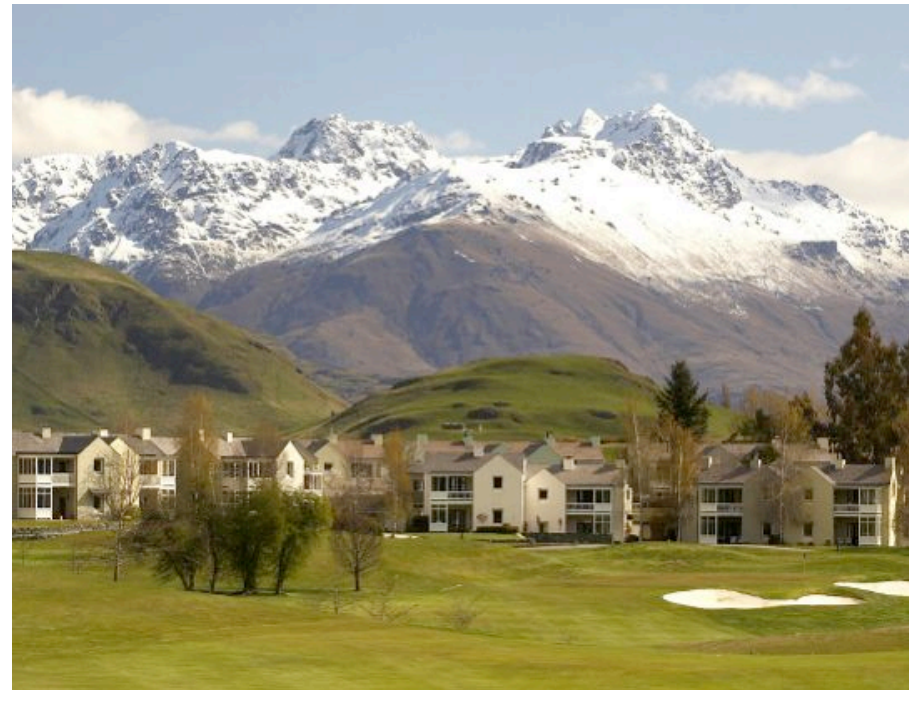

7.20 Before

Retrieved from http://asiarooms.com/en/new_zealand/queenstown/174665 millbrook_resort.htm!

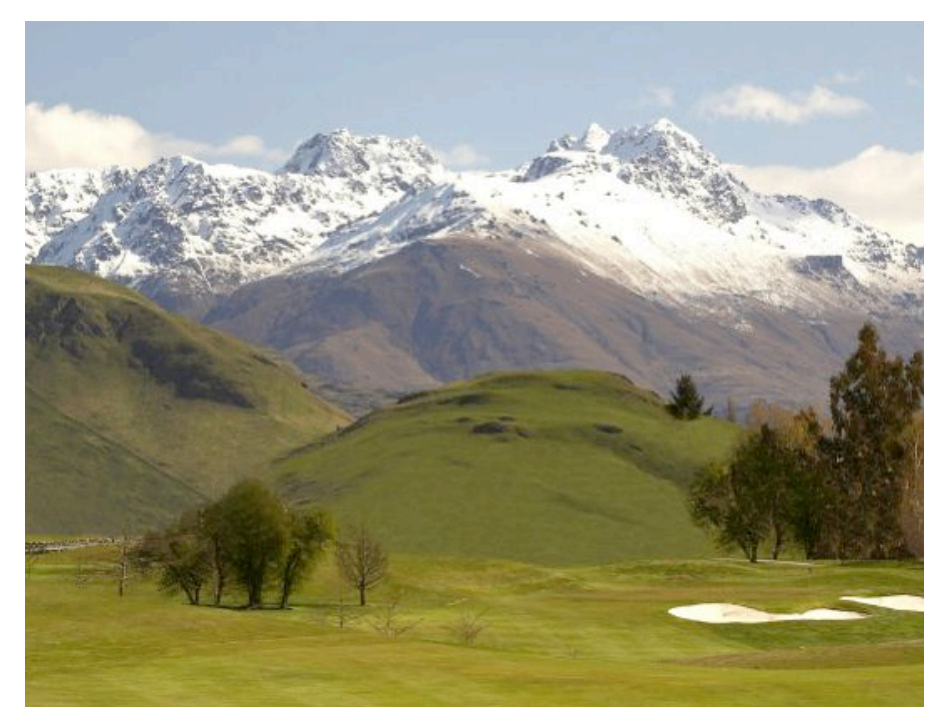

7.21 After

Edited by author from http://asiarooms.com/en/new_zealand/ queenstown/174665-millbrook_resort.html

1993-2012, Various architects, Millbrook Resort, Arrowtown, New Zealand. 


\subsection{Exemplars:}

\subsection{Objects in the Landscape:}

Categorized as 'objects' in the landscape, these exemplar projects manipulate form to strengthen the landscape.

Acting as a beacon in the winter landscape, Tezuka Architect's Matsunoyama Natural Science Museum (2006) operates as a constant reference device to better understand the landscape (Fig 8.1-3). In warmer seasons, the contrast generated with the landscape is reduced - a dynamic response that highlights aesthetic changes in the landscape. While also constructing a balanced composition between architecture and nature, OMA's Jebel al Jais Mountain Resort (2006) shifts architecture into the realm of infrastructure (Fig 8.46). Defying nature with large cantilevers, bridges and dams, the intervention enhances the sublime qualities of the landscape, making it appear more powerful. Architecture Workshop's Peregrine Winery (2004) also enhances the overwhelming qualities of the landscape (Fig 8.7-9). A rare example of large architecture enhancing a New Zealand landscape, the elongated twisting roof confronts the vast nature of the Central Otago landscape. 


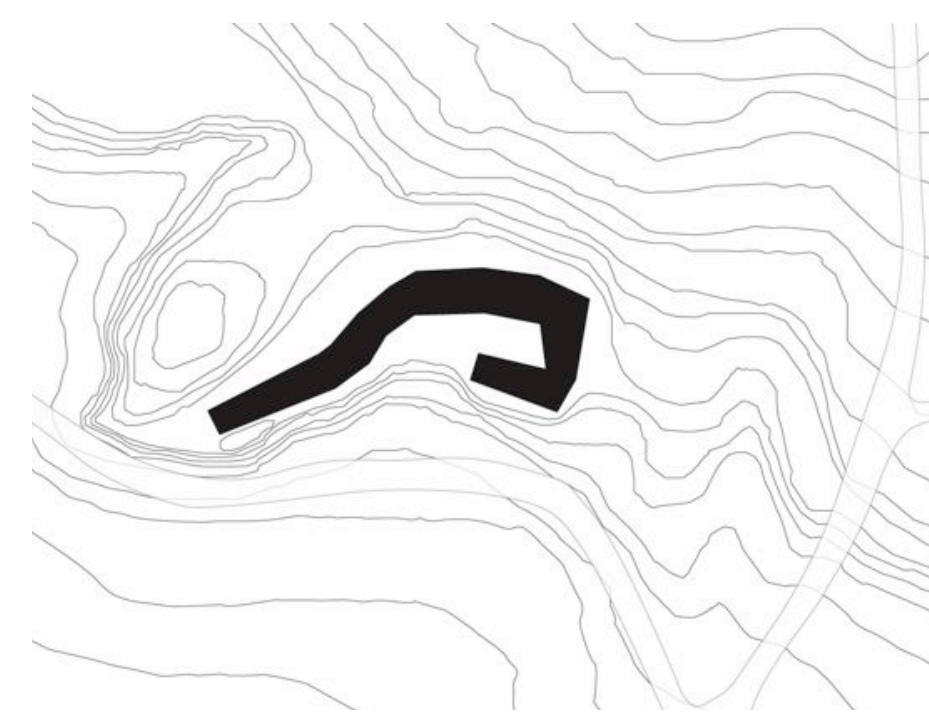

8.1 Figure/Ground

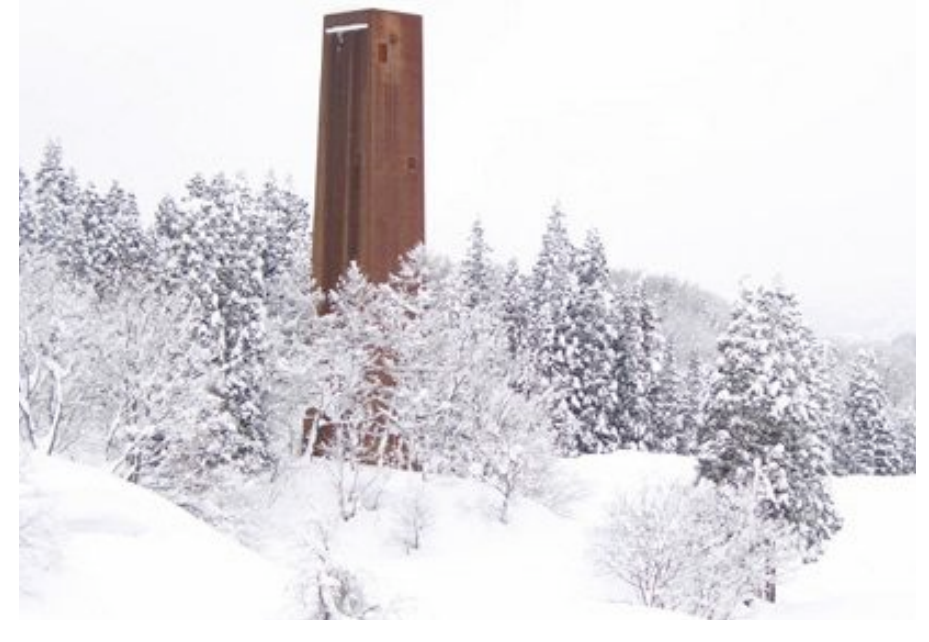

8.2 Before

Retrieved from http://flickr.com/photos/76223770@N00/56831457/

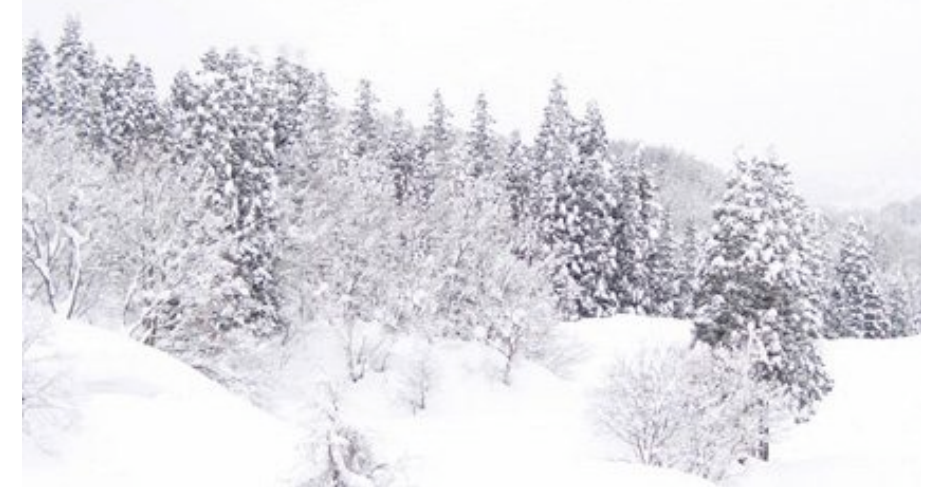

8.3 After

Edited by author from http://flickr.com/photos/76223770@N00/56831457/

2006, Tezuka Architects, Matsunoyama Natural Science Museum, Niigata, Japan. 


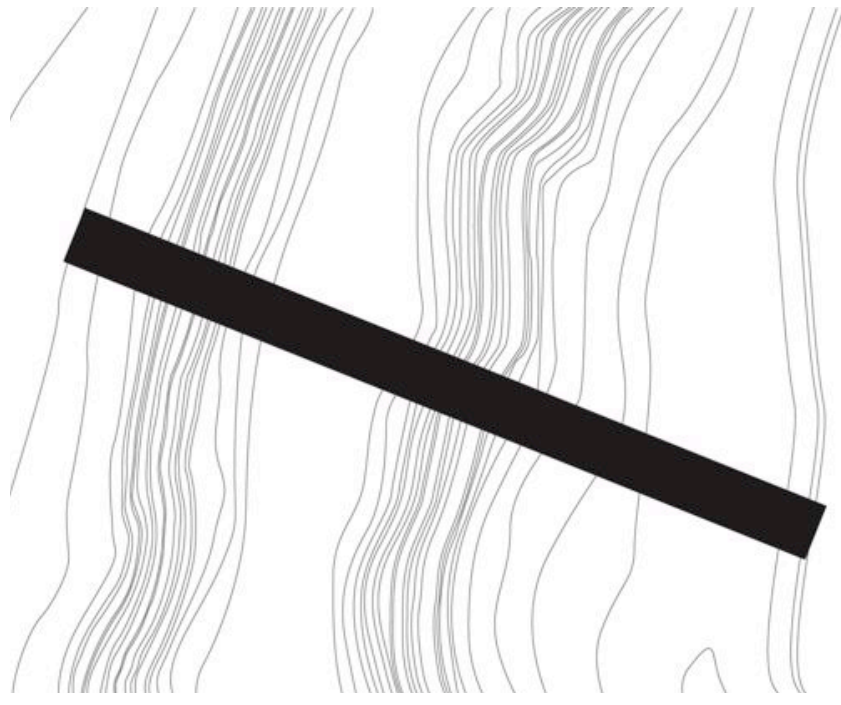

8.4 Figure/Ground

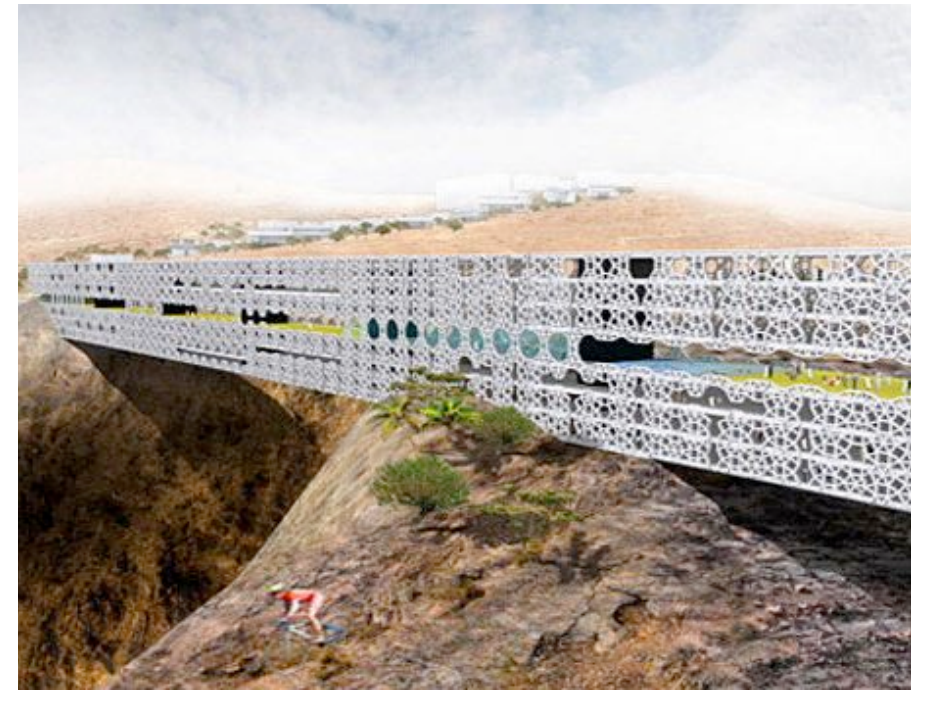

8.5 Before

Retrieved from http://oma.eu/projects/2006/jebel-al-jais-mountain-resort

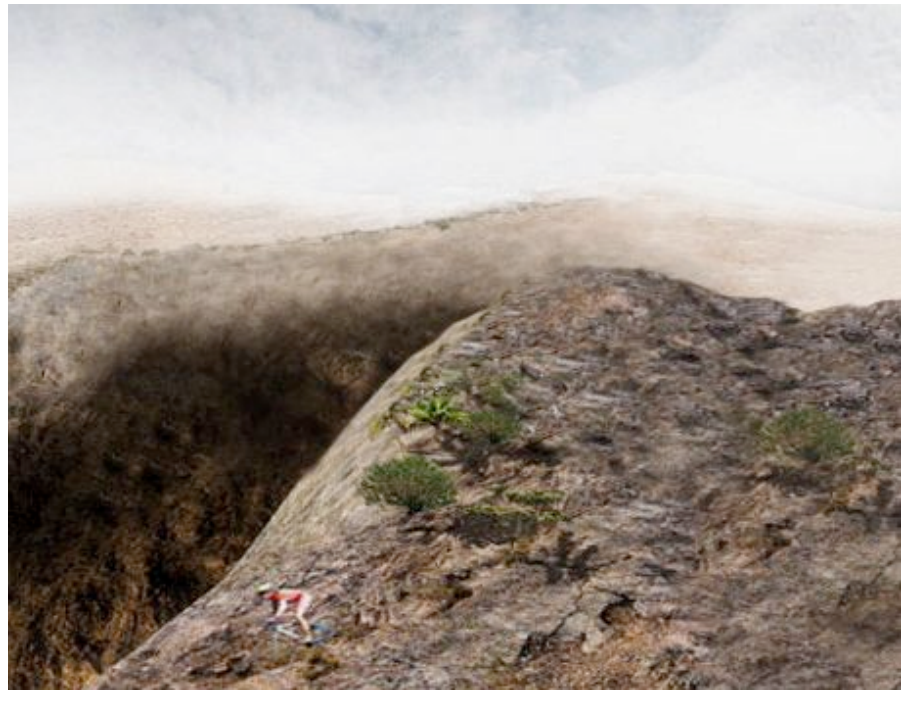

8.6 After

Edited by author from http://oma.eu/projects/2006/jebel-al-jais-mountain-

2006, OMA, Jebel al Jais Mountain Resort, Ras Al Khaimah, United Arab Emirates. 


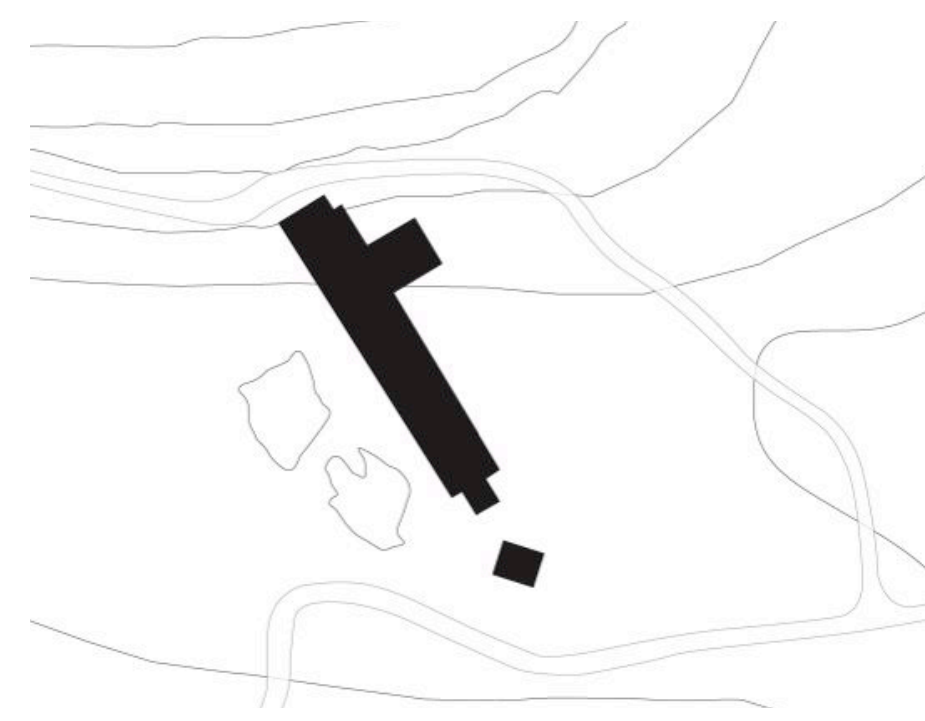

8.7 Figure/Ground

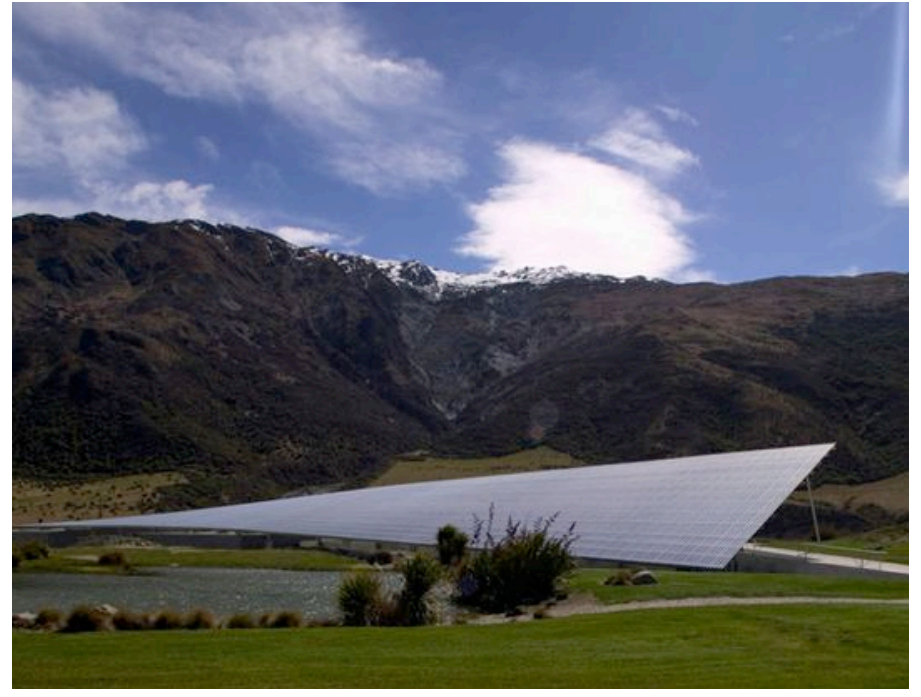

(1) 8.8 Before

In Reynolds, P. (2004). Grape expectations. Architectural Review, 216, 1294.

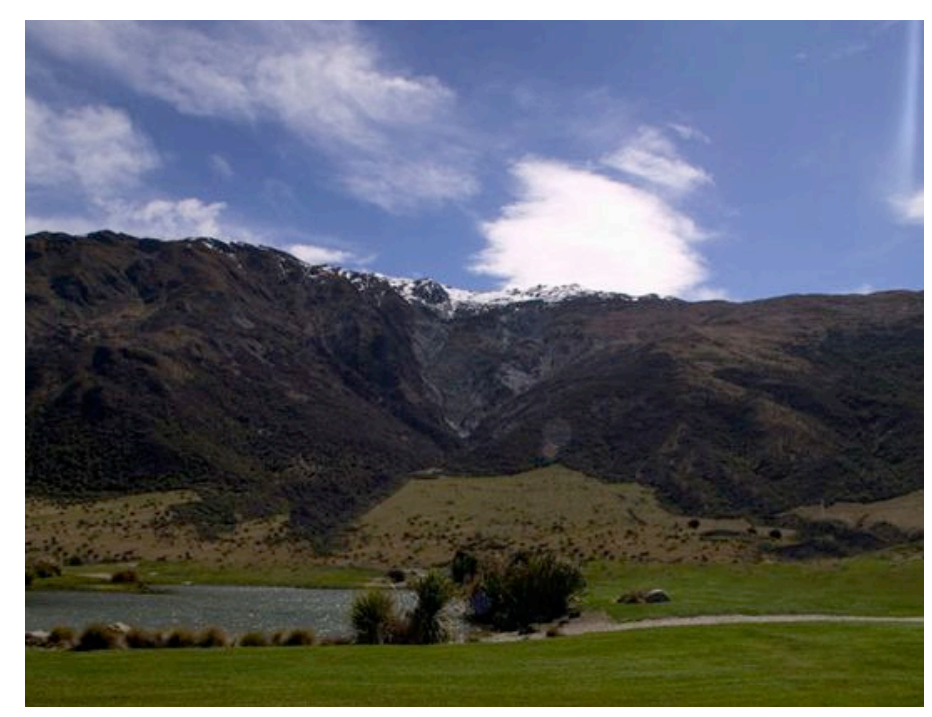

8.9 After

Edited by author from Reynolds, P. (2004). Grape expectations. Architectural Review, 216, 1294.

2004, Architecture Workshop, Peregrine Winery, Gibbston Valley, New Zealand. 


\subsection{Interventions in the Landscape:}

The remaining exemplar formal solutions are categorized as 'interventions' on the landscape.

Operating more as a negative void than an object, Kengo Kuma's Kiro-san Observatory (1994) enhances the landscape through a dramatic architectural incision (Fig 8.10-12). Michael Heizer's Double Negative (1970) also employs a cutting formal strategy to enhance the landscape (Fig 8.13-15). Constructed from purely destructive action, this thesis looks to the formal traditions of land art, particularly of the 1960s-70s, for insight into architectural forms that strengthen the landscape. Several largely overlooked interventions within Te Urewera, including the dam infrastructure as pictured (Fig 8.16-18), will be critically examined, unearthing further formal strategies that enhance the landscape. 


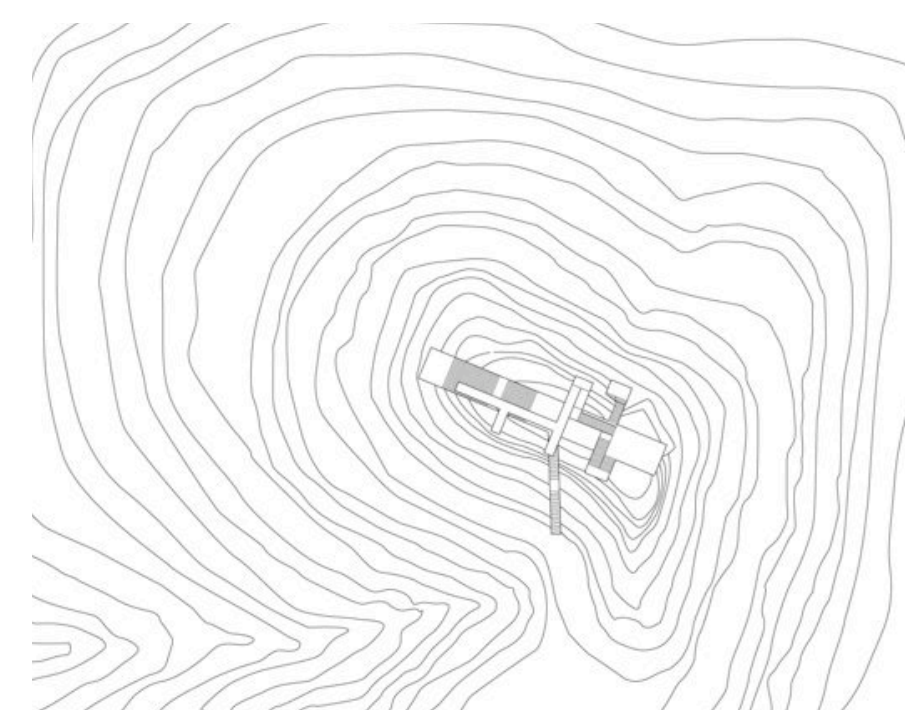

8.10 Figure/Ground

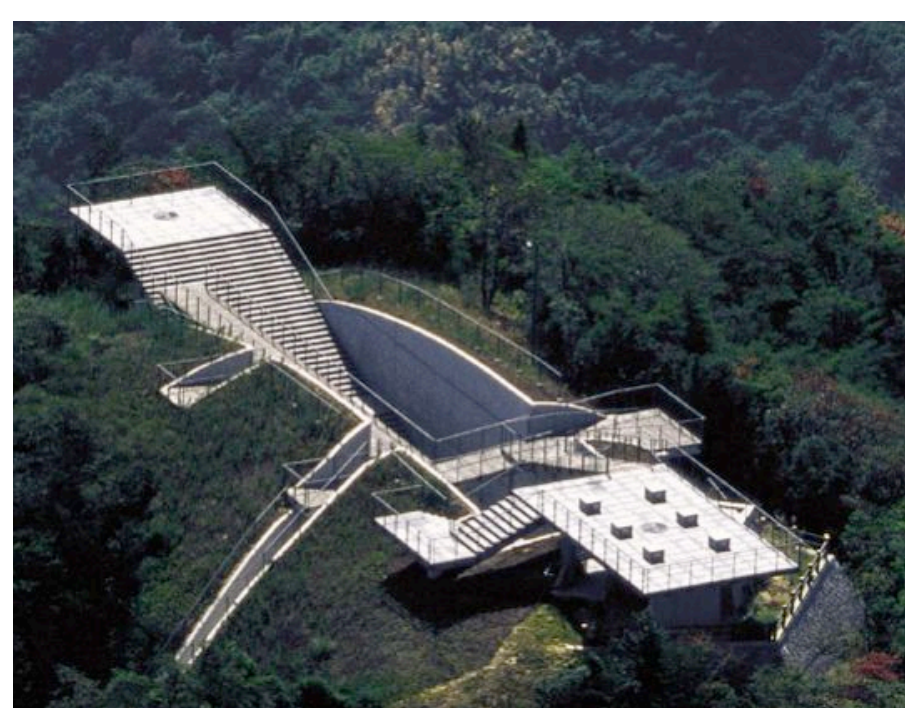

8.11 Before

Retrieved from http://archilab.org/public/2000/architec/visites/kengo01.htm

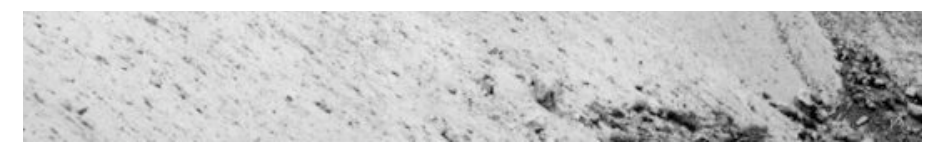

8.12 After

Edited by author from http://archilab.org/public/2000/architec/visites/ engo01.htm

1994, Kengo Kuma, Kiro-San Observatory, Ehime, Japan. 


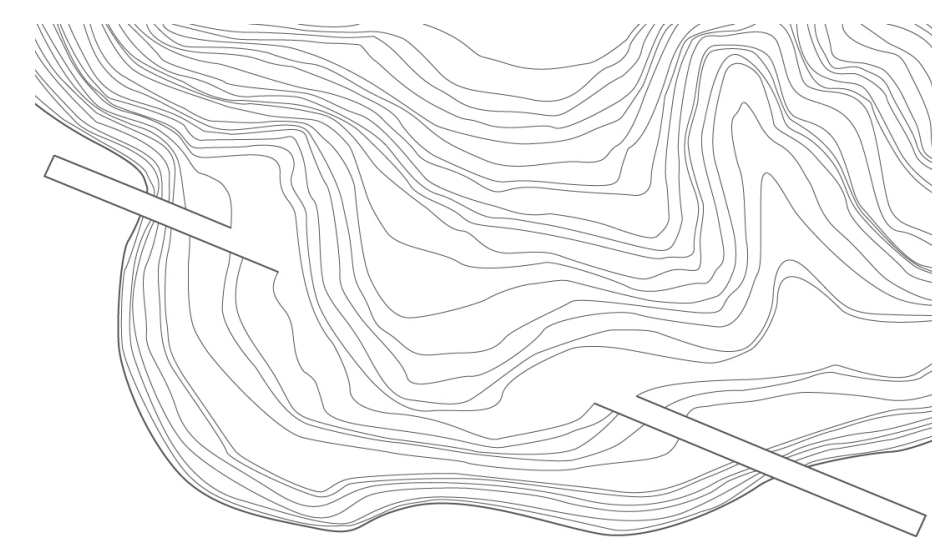

8.13 Figure/Ground

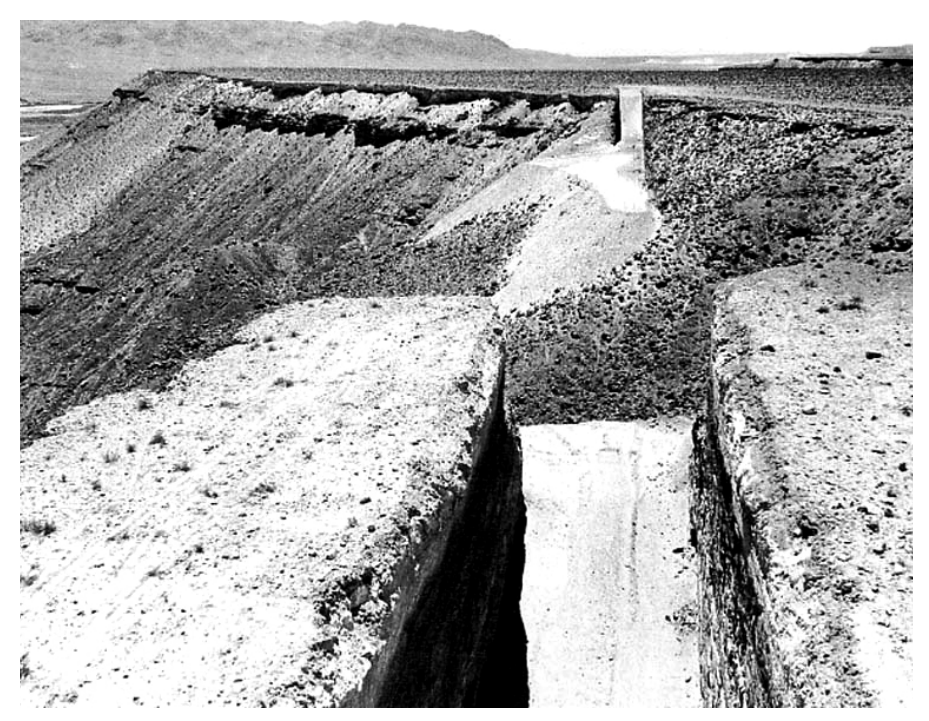

8.14 Before

In Celant, G. (1997). Michael Heizer. Milan, Italy: Fondazione Prada.

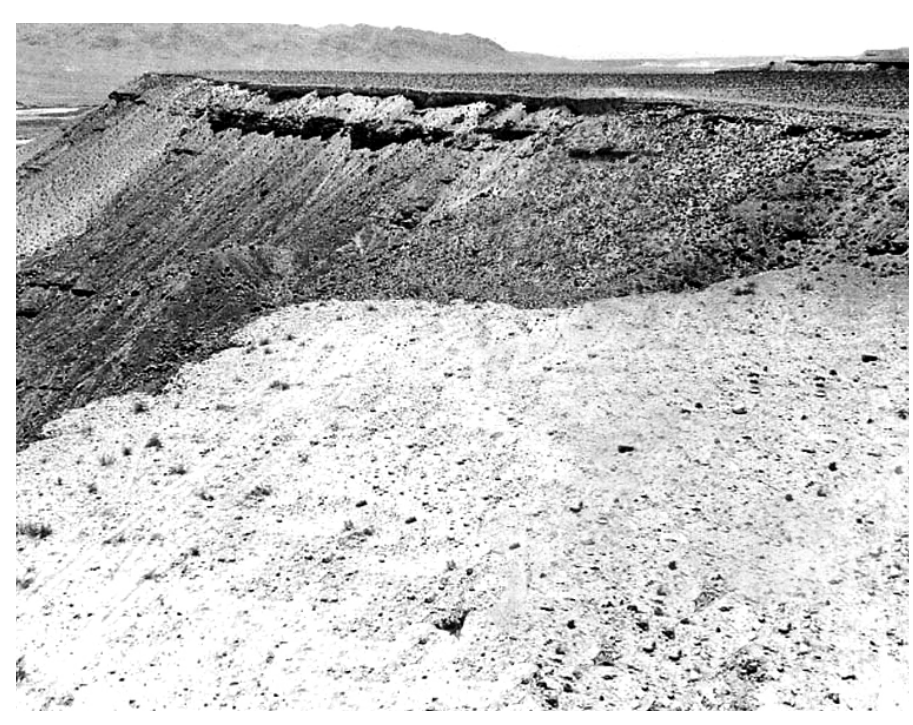

8.15 After

Edited by author from Celant, G. (1997). Michael Heizer. Milan, Italy: Fondazione Prada.

1969, Michael Heizer, Double Negative, Nevada desert, USA. 


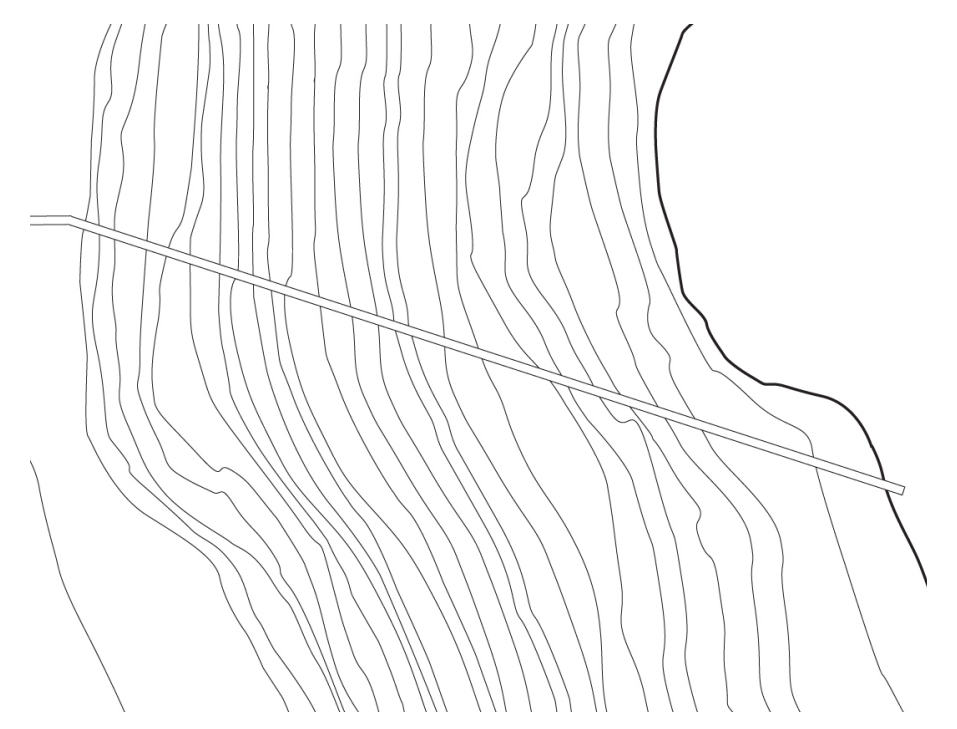

8.16 Figure/Ground
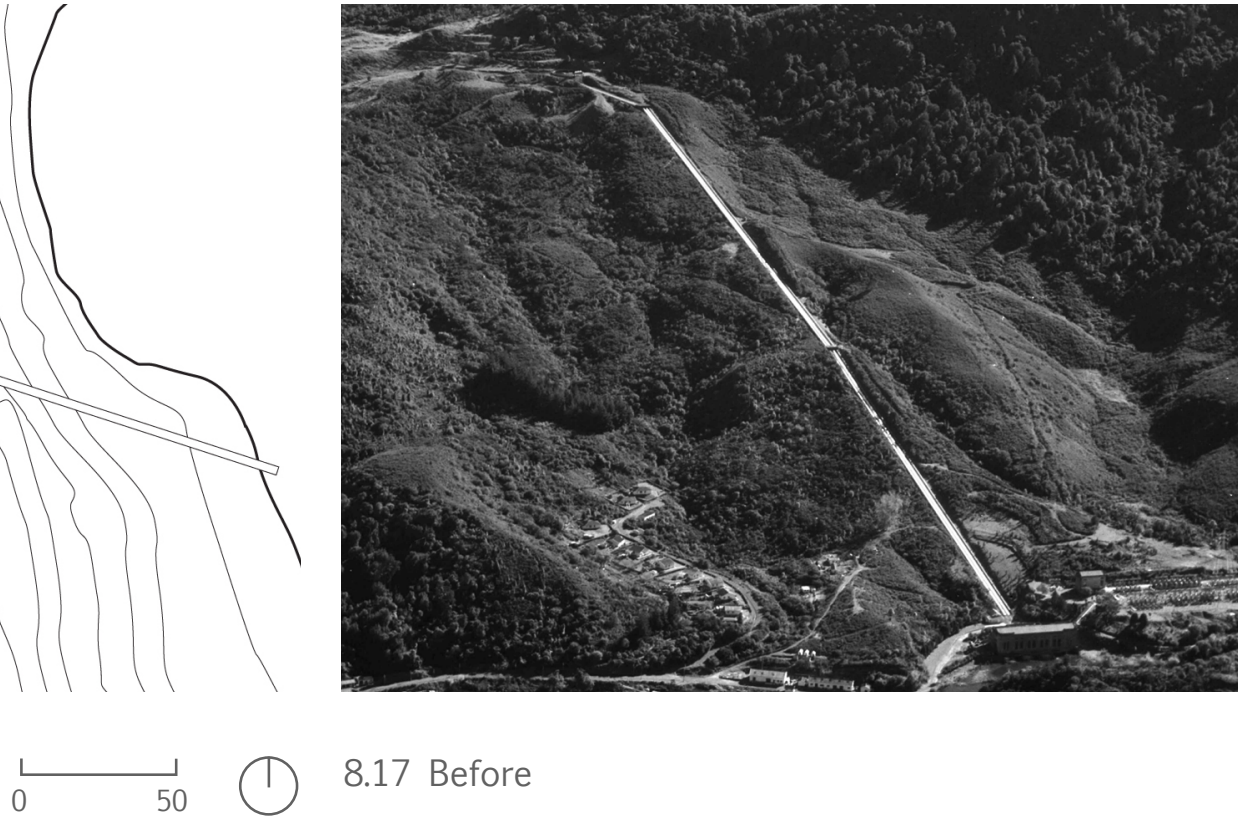

(1)
8.17 Before

Retrieved from Whites Aviation Ltd: Photographs. Ref: WA-46437-G. Alexan-
der Turnbull Library, Wellington, New Zealand. http://natlib.govt.nz/ der Turnbull Library, Wellington, New Zealand. http://natlib.govt.nz,
records/22399952

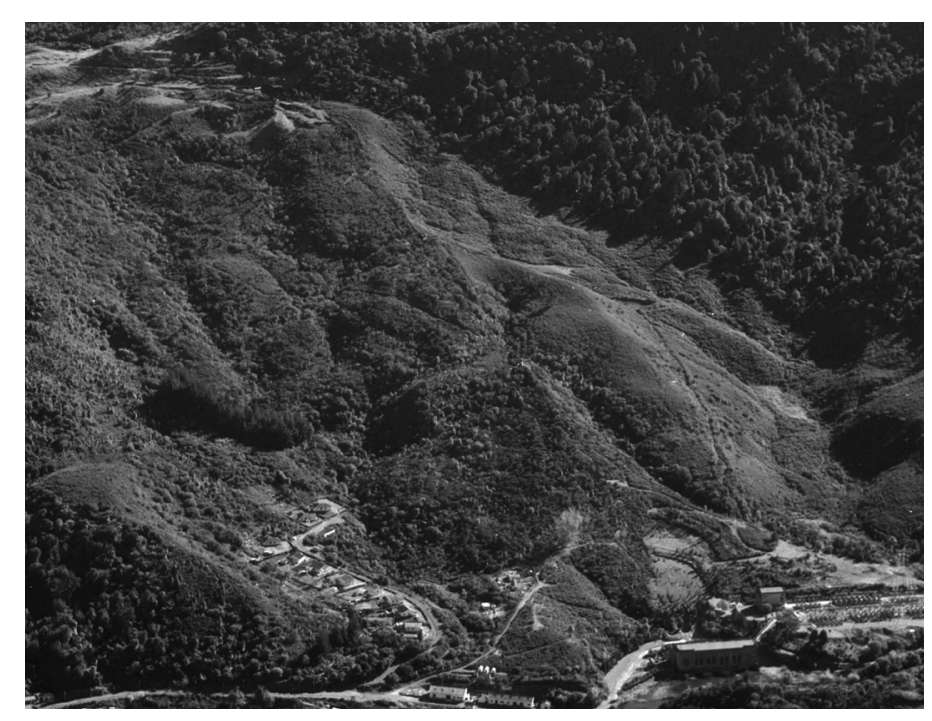

8.18 After

Edited by author from Whites Aviation Ltd: Photographs. Ref: WA-46437-C. Alexander Turnbull Library, Wellington, New Zealand. http://natlib.govt.nz/ records/22399952

1929-1943, New Zealand Public Works Department, Waikaremoana Power Scheme, Waikaremoana, New Zealand. 


\subsection{Theoretical Implications}

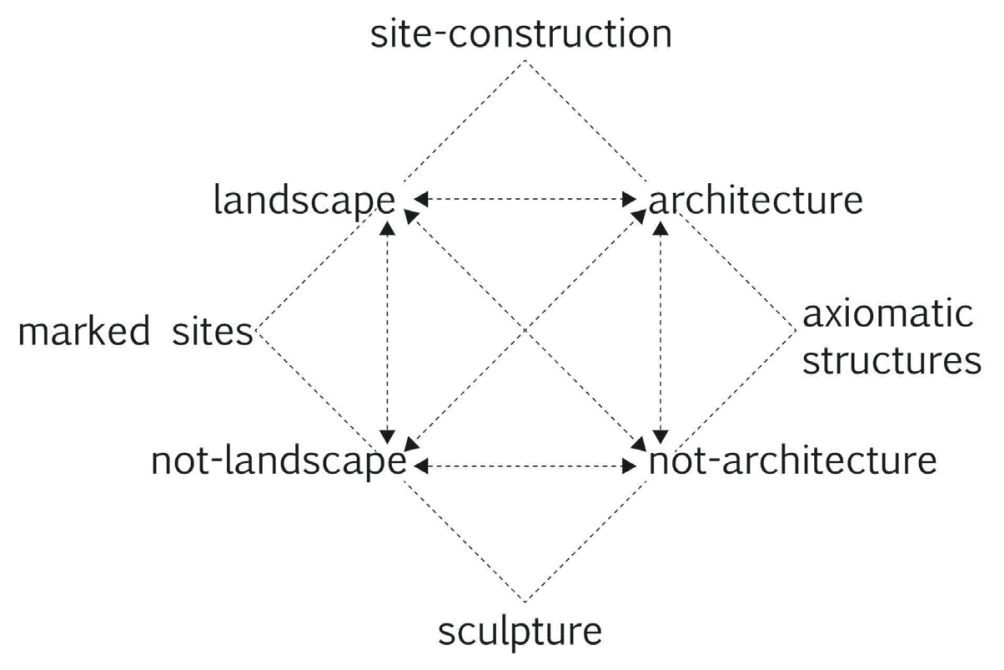

9.1 Krauss, R, (1979). Sculpture in the Expanded Field. In October (Spring), 8. 


\subsection{The Expanded Field}

The exemplar precedents are situated within an expanded field of architecture, land art, and infrastructure, each ultimately bound up with a response to landscape. This thesis will attempt to approach these diffusing borders in such a way that the role of architecture does not become diluted, but remains central to discussion.

While there are many different ways to unearth strategies for building in the landscape, Rosalind Krauss's (1979) inquiry into the expanded field of sculptural practice - and the very works she examines - suggests a productive way forward. Also facing a discipline with increasingly obscured boundaries, Krauss's (1979) seminal essay "Sculpture in the Expanded Field" redefines sculptural practice, unearthing productive new formats and functions for the discipline. Developing into something that was not sculpture, Krauss (1979) establishes a diagram of distinctions (Fig 9.1) that placed these "not-sculptures" in relationship to the non-sculptural arts of landscape and architecture. While crossing into these two disciplinary fields, Krauss (1979, p.37) observed that these interventions were also "not-landscape" and "notarchitecture". Forming a Klein diagram, Krauss (1979) inverted this negative observation ("not-landscape" and "not-architecture") into the positively expressed opposites of "landscape" and "architecture". Qualified in opposition to these distinctions, Krauss's (1979) diagram identifies three categories that can be used to position the expanded projects: "site-construction", "marked sites," and "axiomatic structures." Exploring notions of architecture and landscape, projects within the categories of "site construction" and "marked sites" provide a starting point to reconsider the relationship between architecture and the landscape. 


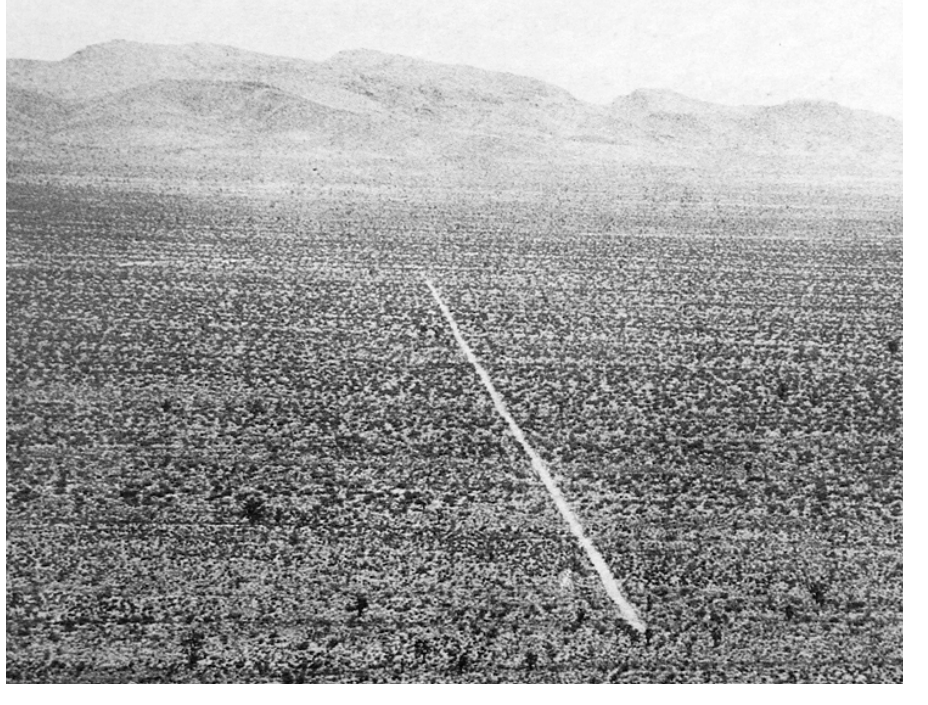

9.2 De Maria, W. (1969) Las Vegas Piece. Desert Valley, Nevada, USA.

In Kastner, J. \& Wallis, B. (1998). Land and environmental art. London, England: Phaidon.

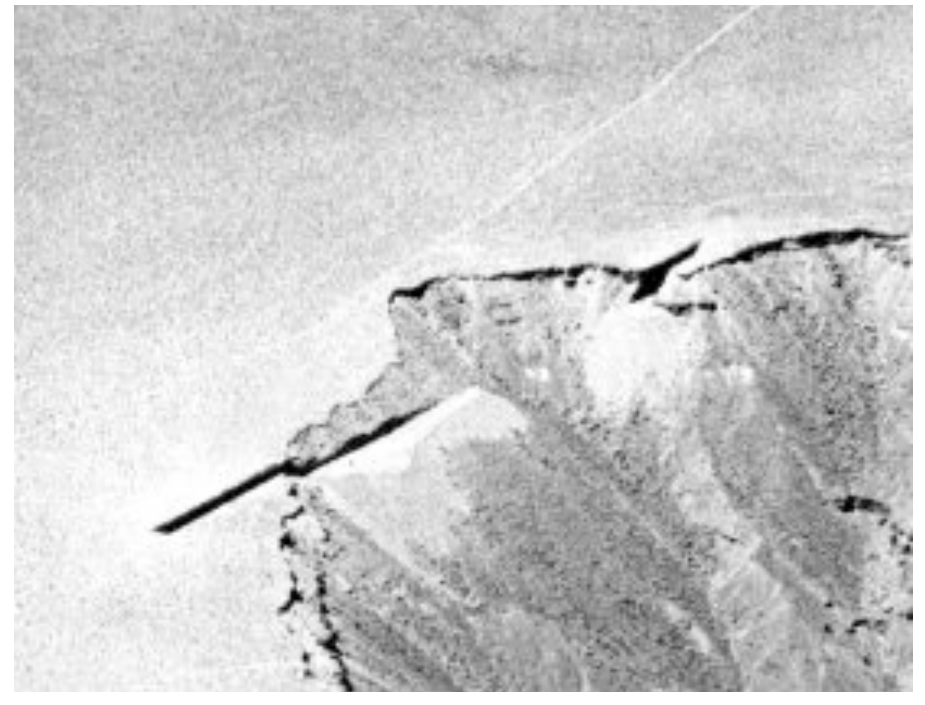

9.3 Heizer, M. (1970). Double Negative. Mormon Mesa, Nevada, USA.

In Celant, G. (1997). Michael Heizer. Milan, Italy: Fondazione Prada.

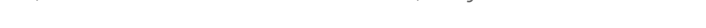

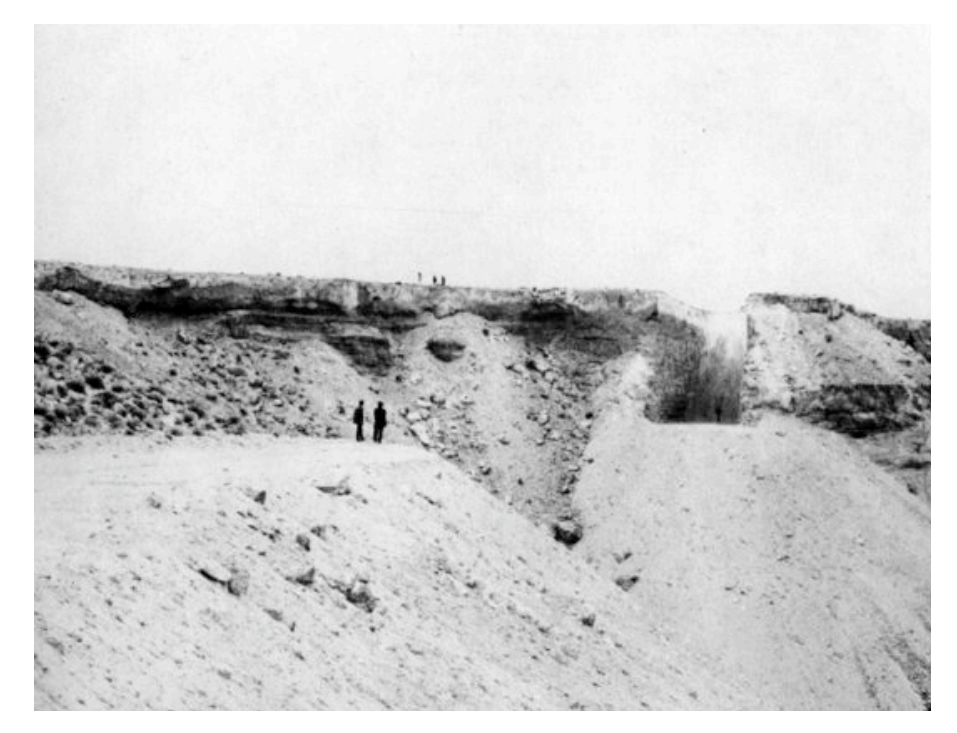

9.4 Heizer, M. (1970). Double Negative. Mormon Mesa, Nevada, USA.

In Celant, G. (1997). Michael Heizer. Milan, Italy: Fondazione Prada. 


\section{Marked Sites:}

"Marked sites" is located between "landscape" and the "not-landscape", incorporating physical manipulations of site and other forms of marking (Krauss, 1979, p.41). The cutting interventions of Walter De Maria's Las Vegas Piece (1969, Fig 9.2) and Michael Heizer's Double Negative (1970, Fig 9.3-4) are useful projects, which can be positioned in this category. Heizer's cutting gesture generates a powerful synergy with the landscape; heightening the overwhelming qualities of the site, while strengthening the intervention through the shear heaviness of the landscape. It would not be difficult to place this cut alongside Immanuel Kant's (2007/1790) Analytic of the Sublime and its reference to such overwhelming interventions as the Great Pyramids of Giza and St Peters of Rome. Departing from other theories of the time, Kant (2007/1790, p.62) identified the sublime as a "negative-pleasure", as the mind is both "attracted and repelled" by the sublime object. This paradox resonates with Heizer's cutting operation; offering a reading of the landscape based on the very notion of uneasiness. Brady (2010, p.127) supports this return to Kant, suggesting that the landscape still has the ability to "impress and overwhelm us", evoking a "mixture of positive and negative feelings" towards the landscape. Encouraged to confront the landscape, the discipline should consider formal solutions that encourage architecture and landscape to be strengthened by each other's presence. 


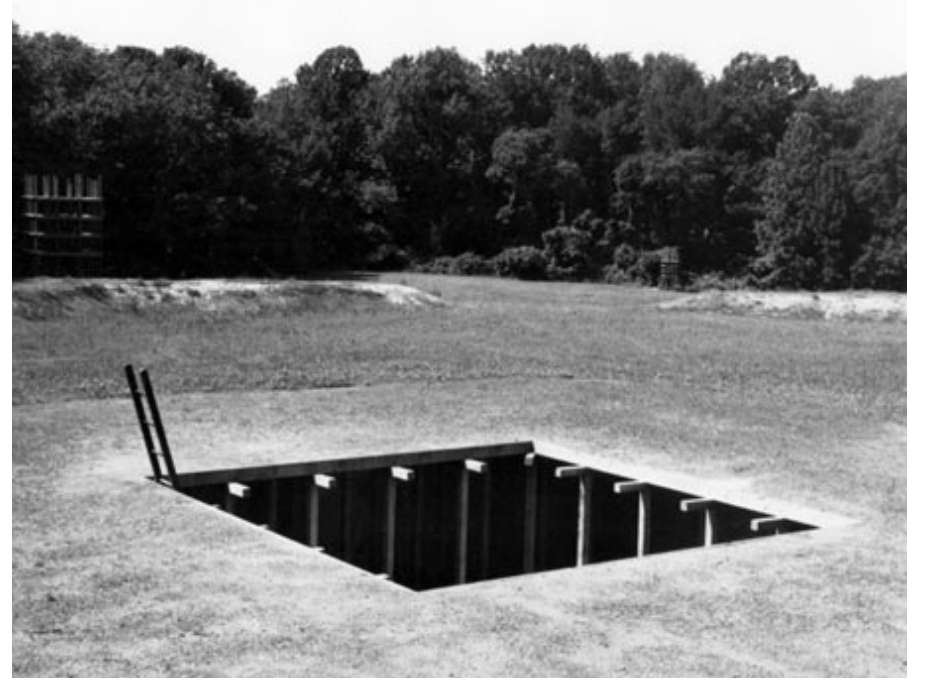

9.5 Miss, M. (1978). Perimeters/Pavilions/Decoys. Nassau County Museum of Fine Arts, New York, USA. In Abramson, D. (2002). Mary Miss. New York, USA: Princeton Architectural.

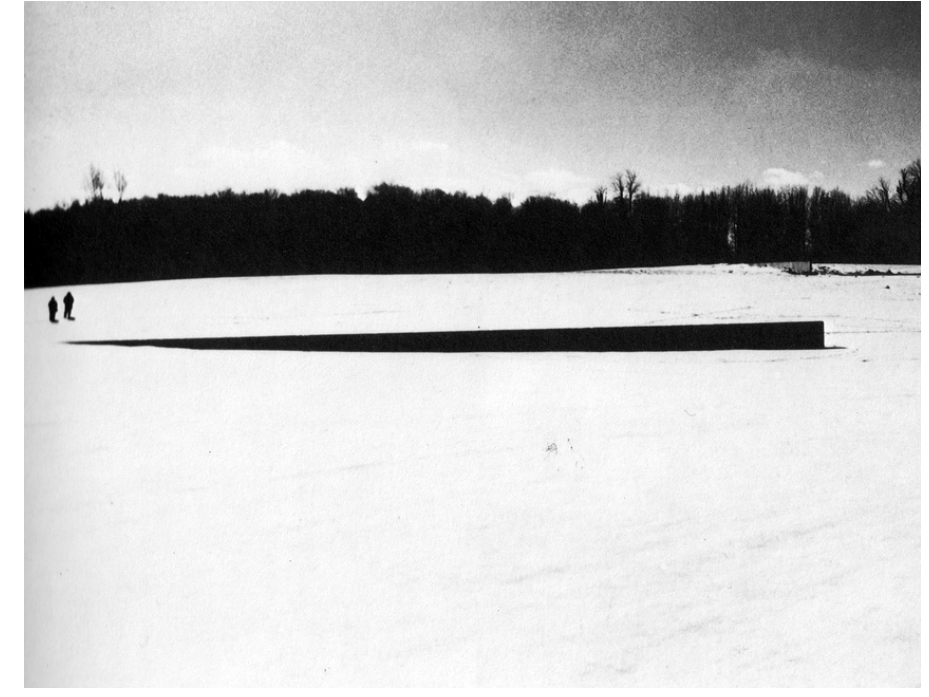

9.6 Serra, R. (1972). Shift. King City, Canada.

Retrieved from http://historyofourworld.wordpress com/2008/12/1 1/shift1970-1972-richard-serra/

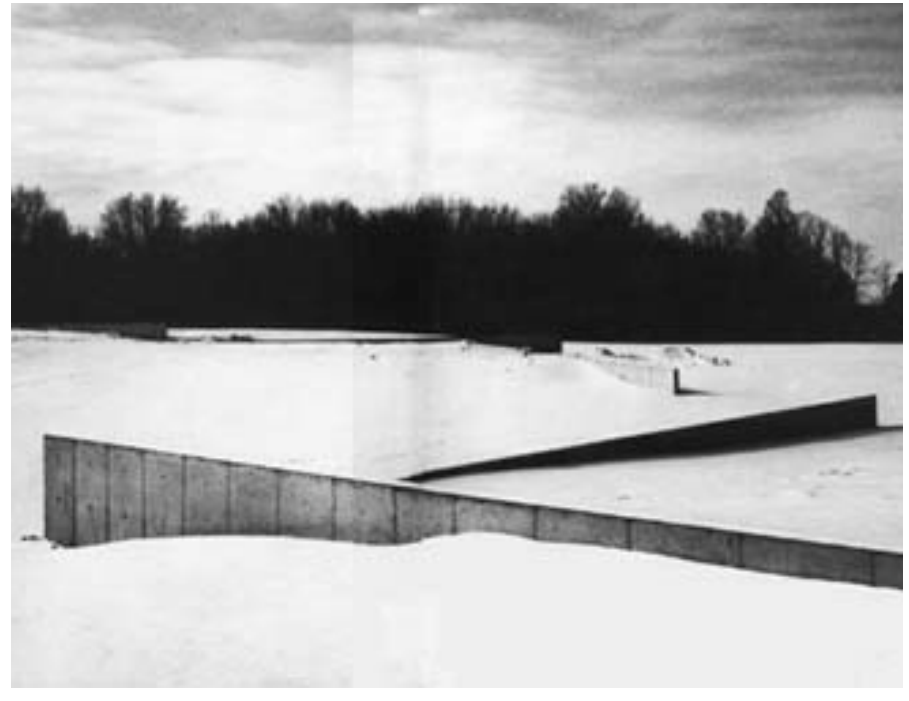

9.7 Serra, R. (1972). Shift. King City, Canada.

Retrieved from http://slowpainting.wordpress.com/2008/02/02/ric hard-serrarobert-smithson-continuum/ 


\section{Site-Construction:}

"Site-construction" occupies the position between "landscape" and "architecture," categorizing works that have reliance on both disciplines (Krauss, 1979, p.41). Mary Miss's excavation Perimeters/ Pavilions/Decoys (1978, Fig 9.5) and Richard Serra's Shift (1972, Fig 9.6-7) are useful examples positioned within this category. In Shift, Serra also employs a formal strategy of cutting the landscape, albeit one of addition. A disagreement between Serra and Peter Eisenman, recorded in a 1983 interview, highlights the productive formal strategies on offer from looking outside the confines of the discipline. When Eisenman spoke of Serra's (1983, p.16) sculptures as "framing the landscape," Serra rejected the picturesque notion of the frame and its "representation" of landscape. Instead, Serra (1983, p.16) promotes a "redefinition" of landscape where sculptural elements act as "barometers for reading the landscape." This unearths possibilities for large, identifiable architectural interventions to redefine landscapes and how are they understood.

\section{Cutting the landscape:}

While not of relevance to Krauss, these "marked sites" and "siteconstructions" all dissect, sever and cut the landscape. In response to the overbearing and timid architectural interventions that continue to diminish our precious landscapes; the formal strategy of the cut offers a productive way forward. Although not positioned within the discipline of architecture, the formal nature of Krauss's (1979) inquiry continues to offer productive critique to architects today, appearing in recently reformatted versions by Anthony Vidler (2005), Infranet Office (2009) and David Adjaye (2012). Vidler's (2005) “Architecture's Expanded Field" identifies four paradigms characterizing developments within the discipline: combinations of architecture-landscape, architecture-biology, architecture-program, and architecture-architecture. The inclusion of an "architecture-landscape" type suggests that while Krauss's land-artists may form important models, the full possibilities of this "not-exactlyarchitecture" (Vidler, 2005, p.153) are perhaps yet to be realized. As this suggests, Krauss's reading of the cut as both "not landscape" and "not architecture" only provides a starting platform for this inquiry. Several overlooked cutting interventions within Te Urewera builds on this knowledge, rethinking various aspects of the cut and how it can operate to enhance the landscape. 


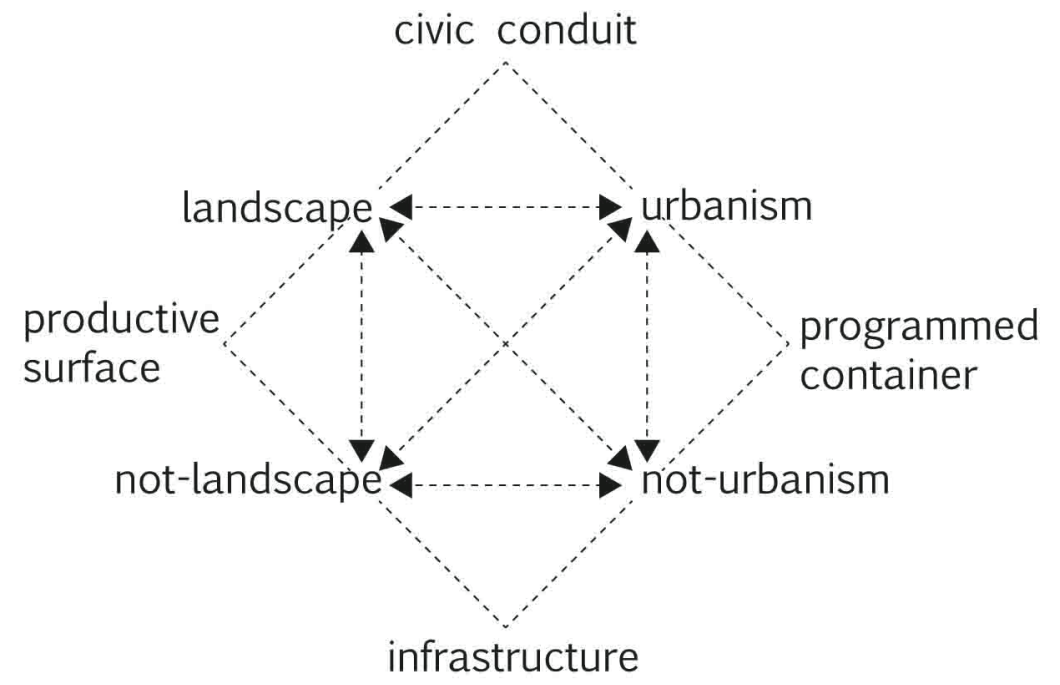

9.8 Bhatia, N., InfraNet Lab (Firm) \& Lateral Office (Firm). (2011). "Infrastructure in the Expanded Field."

In Coupling: Strategies for infrastructural opportunism. New York, USA: Princeton Architectural Press. 


\subsection{Infrastructure in the Expanded Field:}

The role of infrastructure, while not featuring in Krauss's inquiry, offers strategies of opening up the landscape through large cutting interventions. Returning to Krauss, Bhatia et al. (2010) reinterprets her expanded field diagram, releasing architecture from the confines of the field and shifting it into the focus (Fig 9.8). Replacing "architecture" with "urbanism" and "sculpture" with "infrastructure", Bhatia et al. (2010, p.9) suggests architecture could be seen to exist at the ambiguous intersection of these disciplines. Promoting a new movement of "Landscape Infrastructures," Allen (2010) also supports a renewed attention to infrastructure. Shifting from the landscape-dominated practice of “Landscape Urbanism”, Allen's (2010, p.38) "Landscape Infrastructures" reasserts architecture in the design of "large-scale systems and structures." Referencing "connectivity", "systems," "pathways" and "nodes" Allen (2010) can be seen to view infrastructure as a process as much as a material thing; a verb as much as a noun. Rethinking the flows of goods, people and energy, this establishes that architecture should enhance the cultural conditions of the landscape for both visiting and local communities. D'Hooghe (2011, p.85) offers an alternative position, suggesting that infrastructure may be read not as "systems of engineering and transportation," but as "objects of cultural production." With spatial content not unlike that of architecture or sculpture, this suggests infrastructure may be examined within a purely formal context.

Within the remote Te Urewera landscape, several largely overlooked infrastructural interventions open up the landscape through large cutting operations. Providing circulation in an otherwise dense environment, the cutting interventions can be critically analyzed through Allen's (2010) cultural and D'Hooghe's (2011) formal lens. 


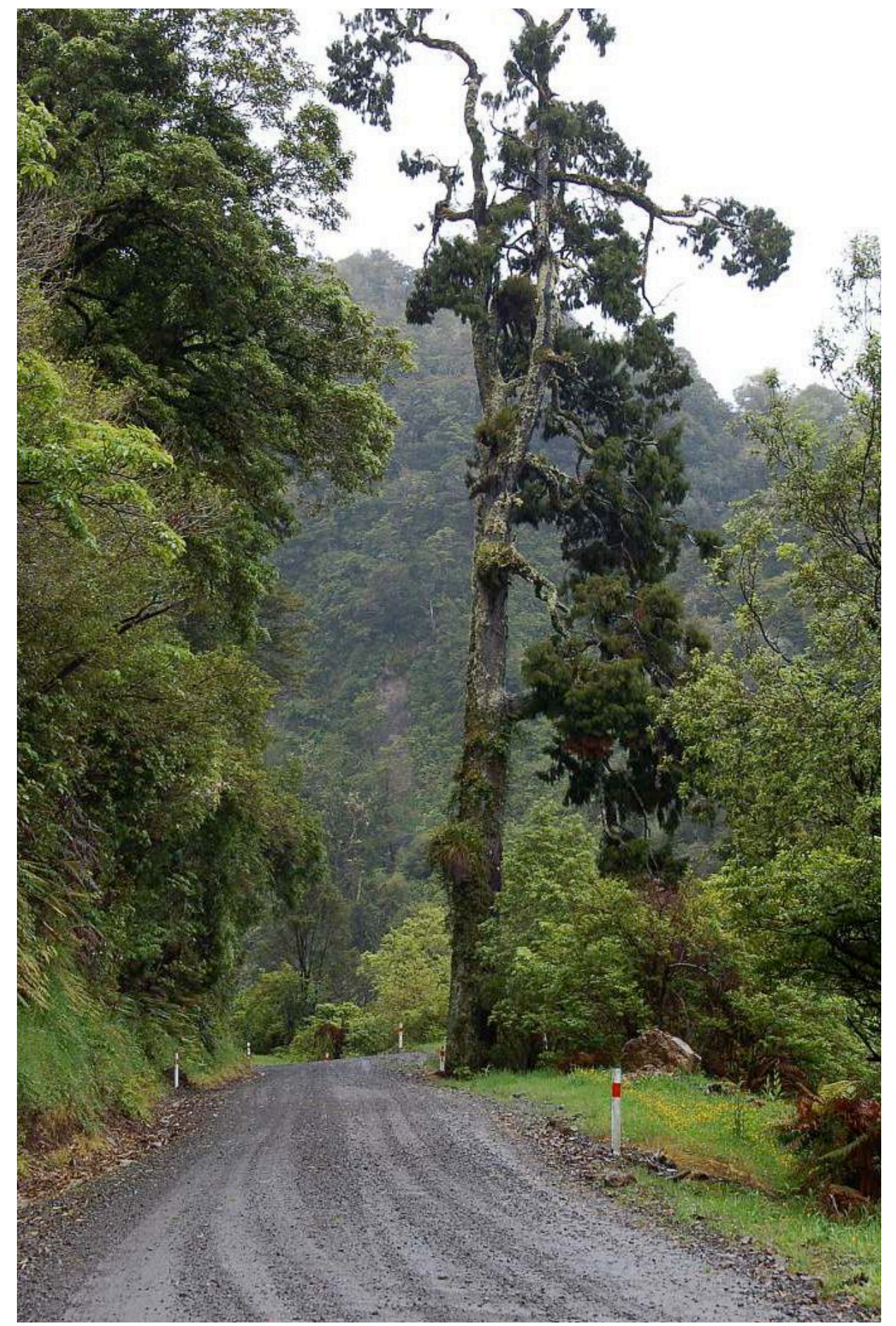

9.14 Cutting Road Operation at Waikaremoana.

Retrieved from http://yukonrambles.blogspot.co.nz/2011/12/rangitaiki-river-and-ruatahuna.html 


\section{Road Infrastructure:}

Roads within Te Urewera cut the densely forested landscape in order to enhance connectivity within the landscape. Principal surveyor, Stanley Brees, (1847, p.481) documented this destructive operation writing of "opening up the country" by tracing the hills and rivers upon which "numerous alleys" would be "cut straight through the forest." Roads that carve out strict linear geometries, with little regard for the preexisting landscape (Fig 9.14-15, 9.17) offer the most productive formal possibilities to this inquiry. Placed alongside "Double Negative" in the tradition of "marked sites," the negative geometries produced suggest how architecture can leverage the dramatic qualities of the landscape.

Culturally, road infrastructure within Te Urewera occupies a difficult paradox of being both constructive and destructive for the local Tūhoe people. For over a century the prospects of roads have divided Tūhoe, with some welcoming an end to their isolation (Park, 2006, p.225) and others fearing the unknown possibilities they may bring to their otherwise autonomous land (Binney, 2009, p.271). This paradox was recently highlighted at the 2004 Waitangi Tribunal, where claims were lodged both in support and opposition to their construction. While this could be viewed as an inconsistency, it could also be seen to reveal the bilateral nature of this operation, as both culturally constructive and destructive. Colin McCahon's "Urewera Mural" (1974), while not sculpture or within Krauss's field, supports this observation. McCahon ambiguously depicts the Waikaremoana road as a thin red line weaving across the landscape (Fig 9.18) - a line which Park (2007, p.61) views as culturally constructive - a "bloodline of sentiment, hope and endeavor," but which could conversely be read as destructive - a bloodied colonial cut in the landscape. While this highlights the difficulties of building within contested landscapes, it also reveals that by boldly confronting the natural environment, the cut provides an effective and unforgiving strategy of circulating the landscape. 


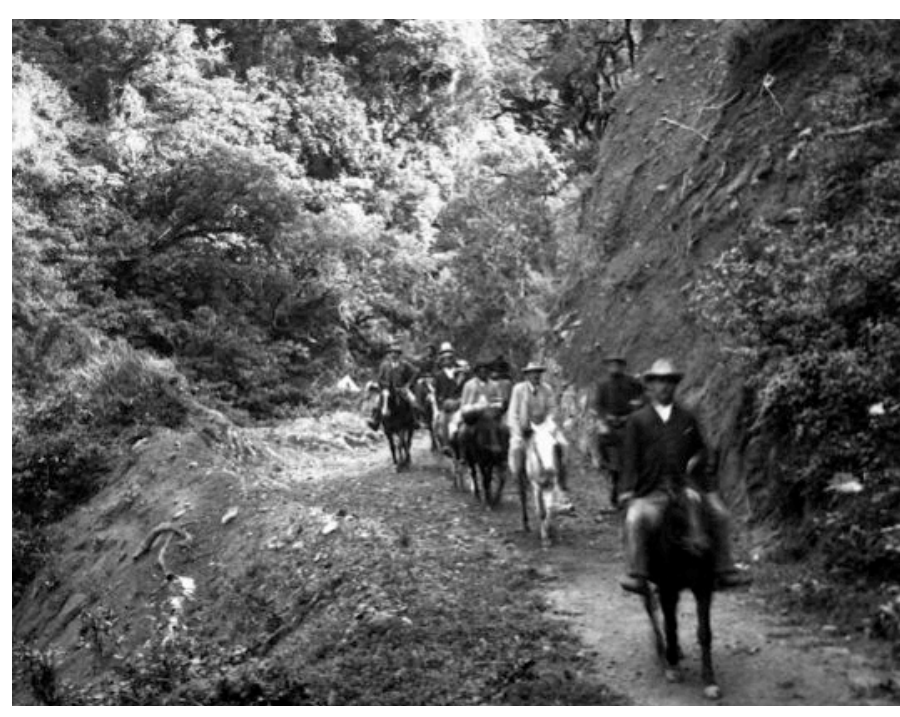

9.16 Malcolm, R. (1904). On the mountain track to Te Whaiti. Retrieved from Ranfurly family: Photographs. Ref: PA1-q-634-23. Alexan-
der Turnbull Library, Wellington, New Zealand. http://natlib.govt.nz/ records/22916582

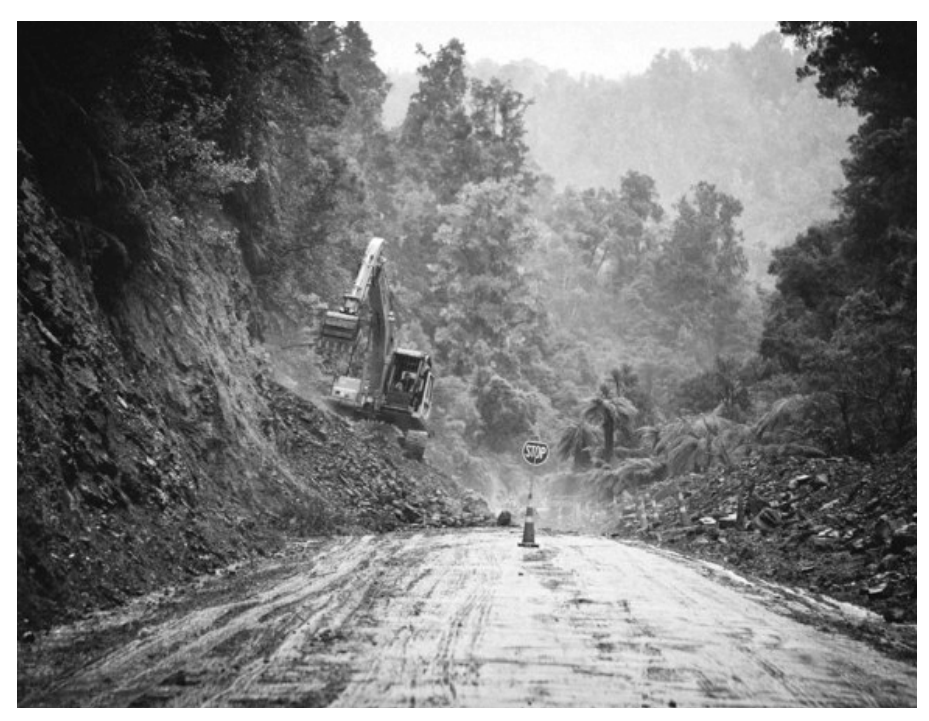

9.17 Couldrey, J. (2011). Slip, Old Ruatahuna Road. Retrieved from http://agathering.co.nz/jennys_gallery/page/5/article/43/

(n)

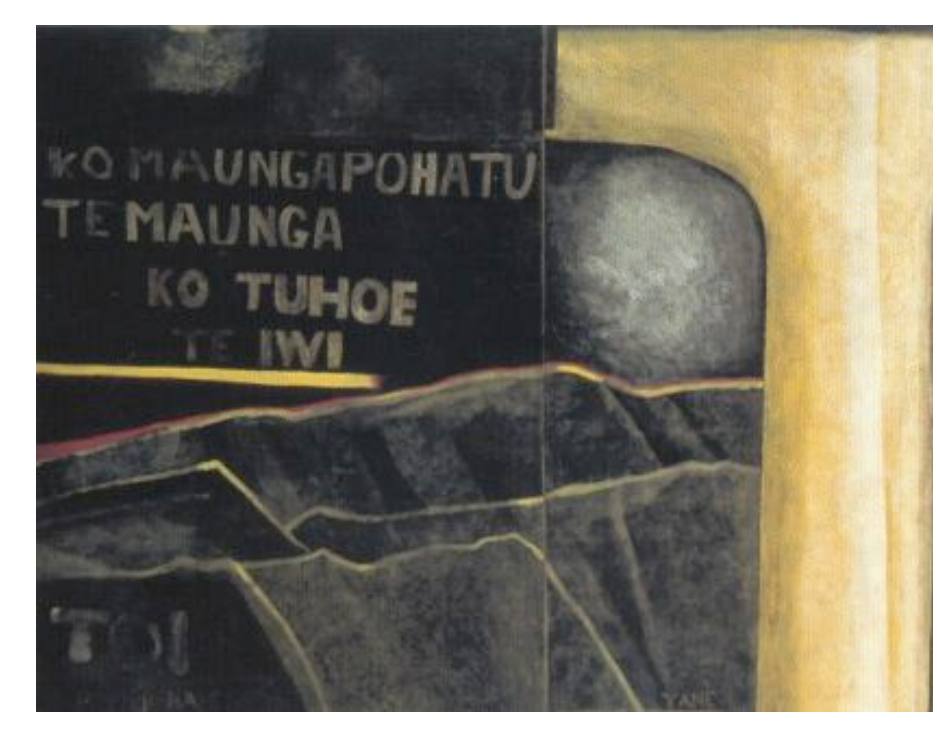

9.18 Mccahon, C. (1975). Urewera Mural. Acrylic on cotton duck, Auckland Art Gallery, on loan from the Department of Conservation Te Papa Atawhai

Retrieved from http://aucklandartgallery.com/the-collection/browseRetrieved from http://au
artwork/15676/urewera-mural 


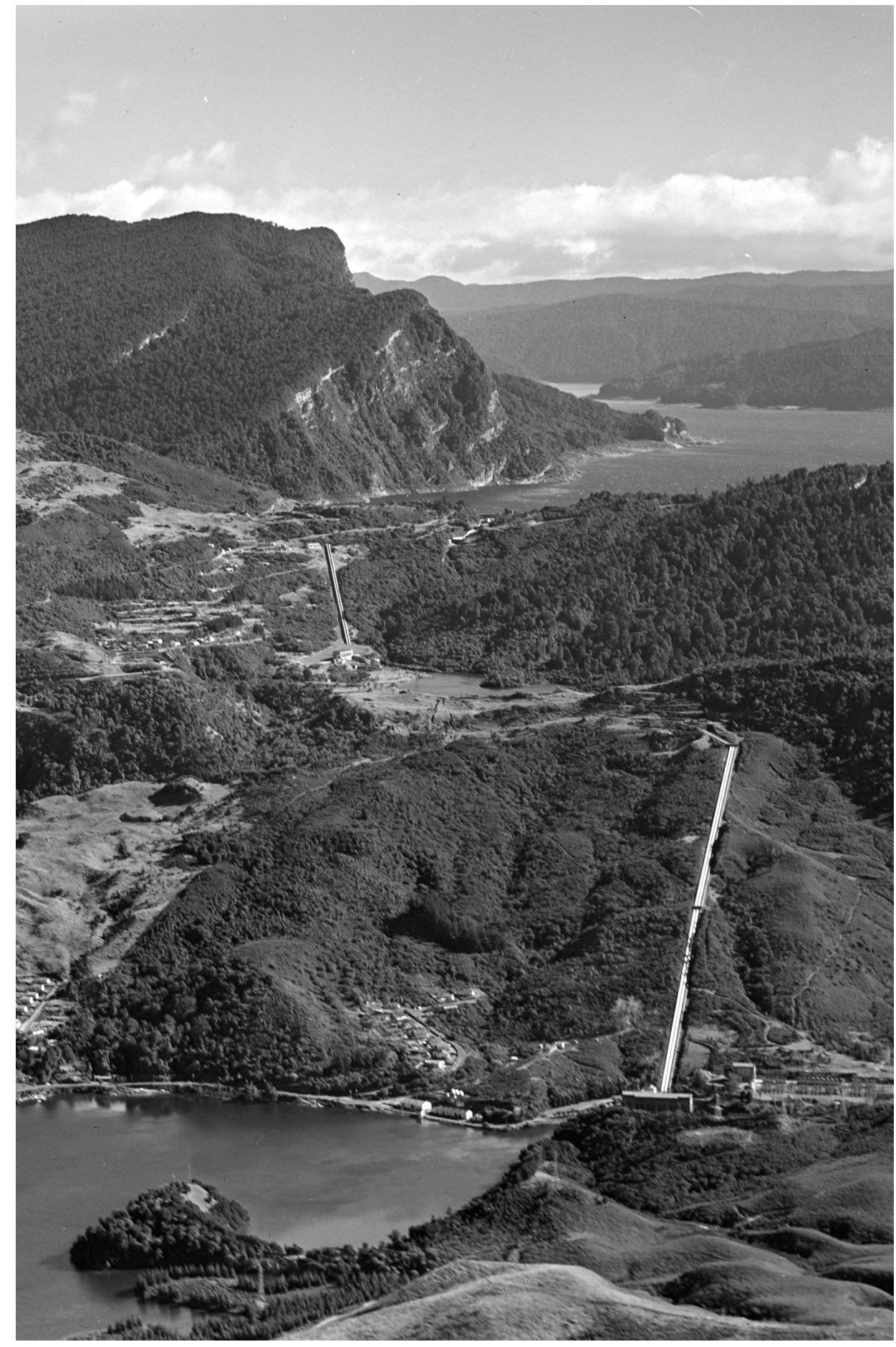

9.20 New Zealand Public Works Department. (1929-1943). Waikaremoana Power Scheme. Waikaremoana, New Zealand.

Retrieved from Whites Aviation Ltd: Photographs. Ref: WA-46437-G. Alexander Turnbull Library, Wellington, New Zealand. http://natlib.govt.nz/records/22399952 


\section{Dam Infrastructure:}

The installation of tunnels, headgates, penstocks and spillways at Waikaremoana also employs cutting strategies to enhance connectivity. Constructed through destructive action, the intervention allows water to flow from Lake Waikaremoana via tunnels to three power stations, discharging in Lake Kaitawa, Whakamarino and the Waikaretaheke River along the way (Natusch, 2004, p.8). Examined as objects of cultural production it could be argued that like Serra's Shift, the linear geometries of the penstocks act as devices for better reading the landscape (Fig 9.20). In this way, the intervention offers a severing cross section through the landscape (Fig 9.24). Echoing Heizer's scale and destruction, with the precision of Serra, the overwhelming perspectives generated from the penstocks (Fig 9.22) could also be seen to enhance the dramatic qualities of the landscape.

The culturally destructive effects of the dam infrastructure at Lake Waikaremoana reveal the potential dangers of imposing large-scale interventions in remote landscapes. Unlike road infrastructure, the dam interventions have had a solely destructive impact on locals - altering Tūhoe's "spiritual" and "physical" relationships to the landscape (Rangitauira \& Co, 2004, p.117). The diversion, flooding and draining of waterways has strained their economic and social wellbeing, altering the seasonal pattern of lake levels, food sources and aquatic ecologies. (Single et al., 2011) Excluding aesthetic considerations, the only cultural benefit from the intervention is the electricity generated by the three stations - electricity which benefits communities far removed from its culturally destructive ramifications.

While the design of a hotel may not have the same destructive implications as a road network or a dam, it is critical that architectural interventions enhance the cultural conditions of the landscape. Unapologetically cutting the landscape, both road and dam interventions offer productive strategies for enhancing the dramatic qualities of the landscape and the way in which it is circulated. 

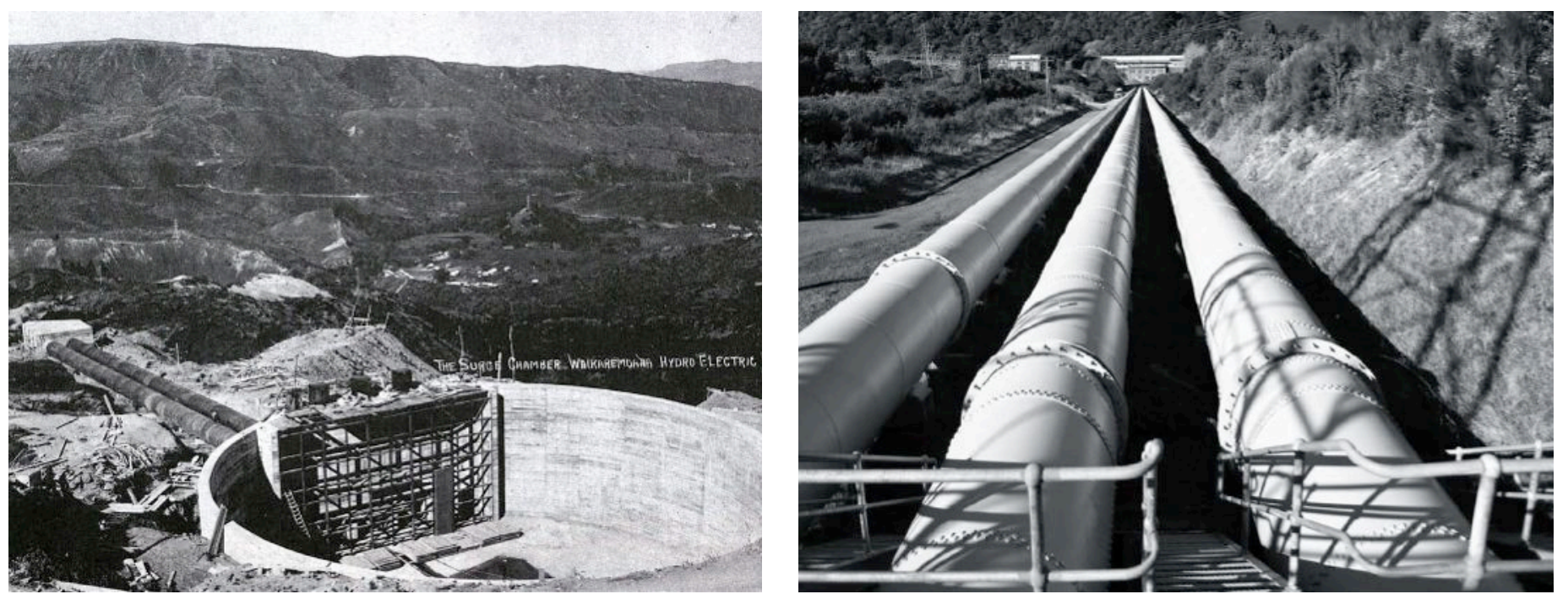

9.21 New Zealand Public Works Department. (1929-1943).

Surge Chamber. Waikaremoana, New Zealand.

In Natusch, G. (1992). Power from Waikaremoana: a history of Waikaremoana hydro-electric power development. Tuia, New Zealand: Electricorp Production.

\subsection{New Zealand Public Works Department.} (1929-1943). Penstocks. Waikaremoana, New Zealand.

In Genesis Power Limited. (2012). Waikaremoana Power Scheme, Annual Environmental

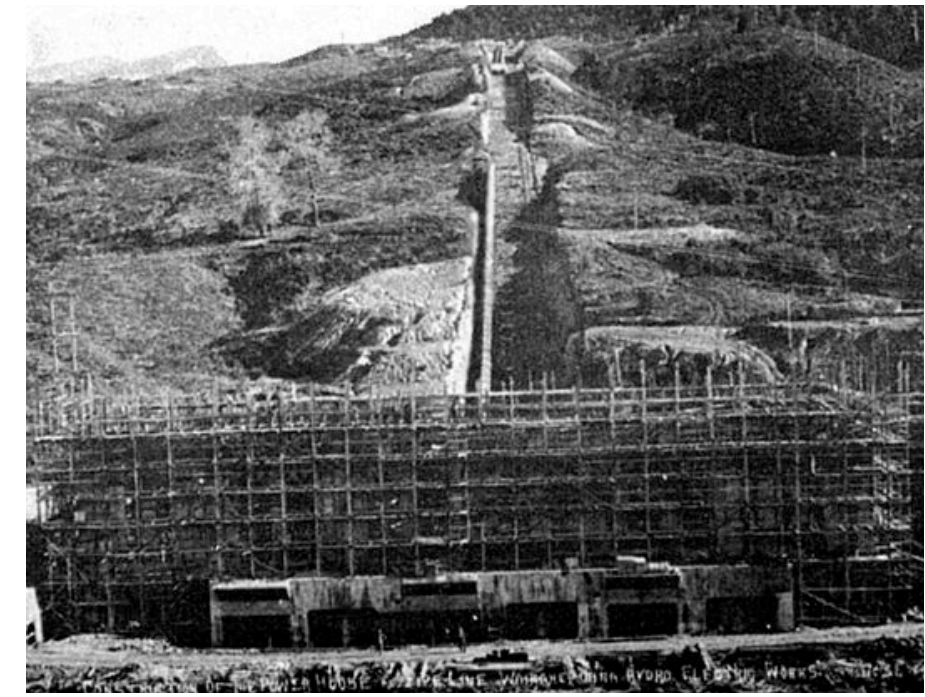

Fig 9.23 New Zealand Public Works Department. (1929-1943). Construction of Power House Pipeline. Waikaremoana, New Zealand.

In Natusch, G. (1992). Power from Waikaremoana: a history of Waikaremoane hydro-electric power development. Tuia, New Zealand: Electricorp Production. 


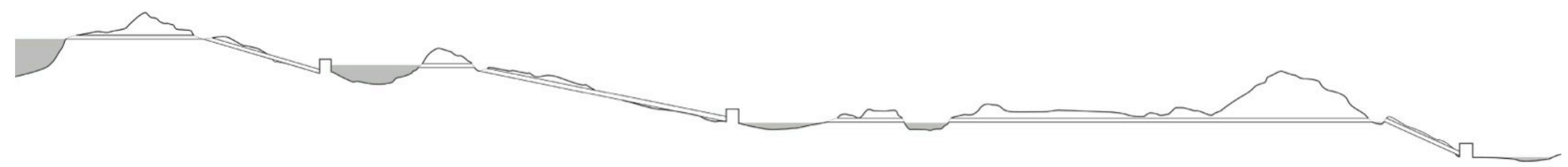




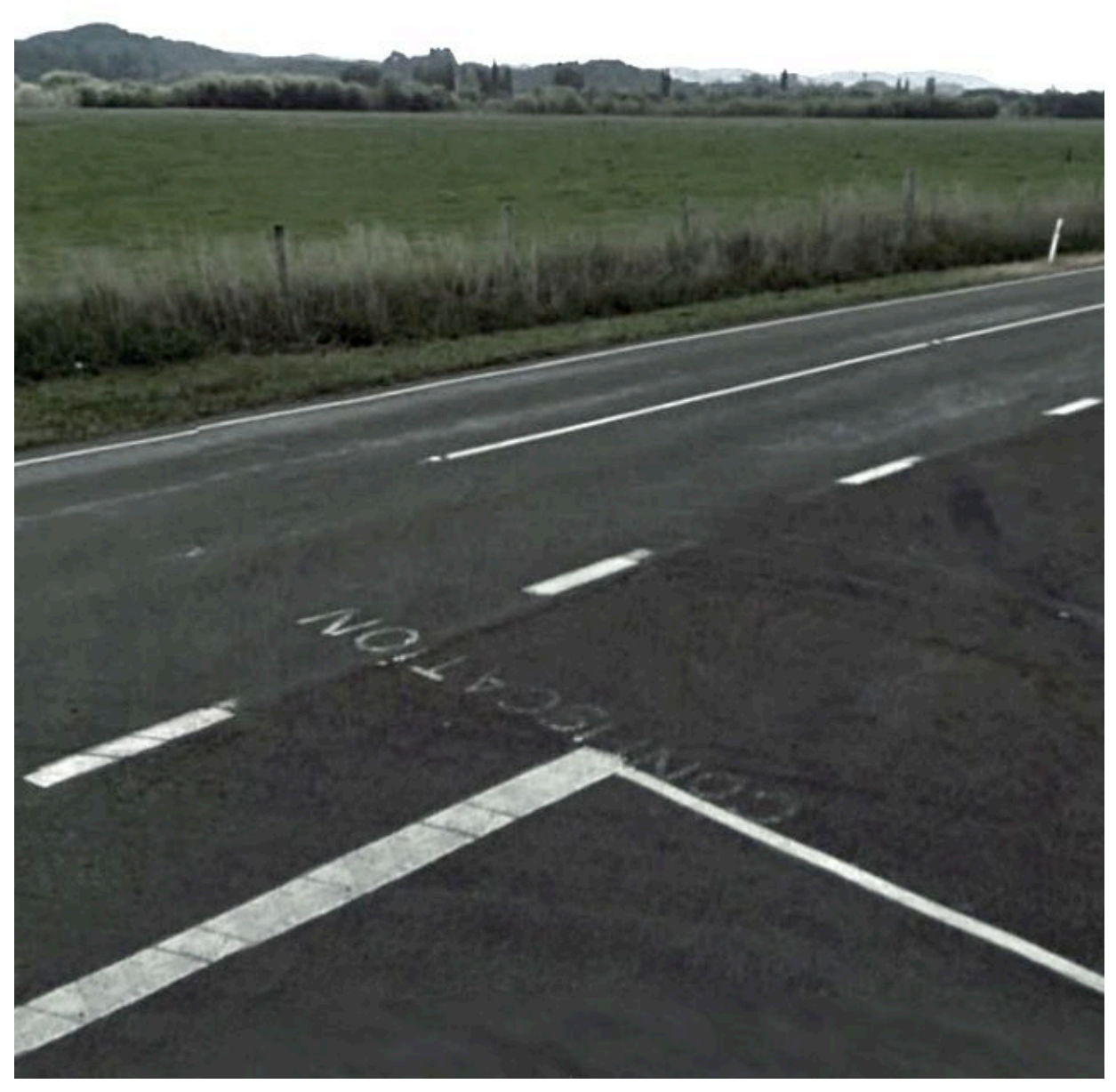

9.25 Confiscation Line. Ruatoki, New Zealand.

Retrieved from www.maps.google.co.nz 


\subsection{Border Control:}

While Krauss refers to De Maria's cutting lines in the desert, she does not discuss their relationship to territories and mapping and the implications this may have for large architectural interventions in the landscape. Constructed from four destructive bulldozer cuts, De Maria's Las Vegas Piece etches an artificial grid over curved natural streams in the desert. Physically digging into the earth, Kastner et al. (1998, p.47) suggests these "earthmarks" comment on how land ownership and mapping is imposed on the natural landscape. Within architectural discourse there is a growing interest in territories and mapping, with Gissen (2010) promoting a shift to a new geographical framework. Advancing maps over plans, and the flow of matter over subjects (Gissen 2010, p.44), this approach brings architectural territories, irrelevant of their scale, into focus. Discussed largely within urban environments, the implications within remote landscapes offer largely untested outcomes. Allen (2010, p.37) hints at what these possibilities may be, suggesting that unlike buildings natural ecologies do not respect borders, but instead "range through territories of multiple scales." In response to these vast scales, Biklsma (2004, p.2) encourages architecture to confront the landscape, entering into large-scale interactions with the natural environment. Within this context, Gissen's (2010, p.43) territorial section - a tool for articulating social flows - would champion ecological cross sections over urban flows and built form sections (Fig 9.27). 

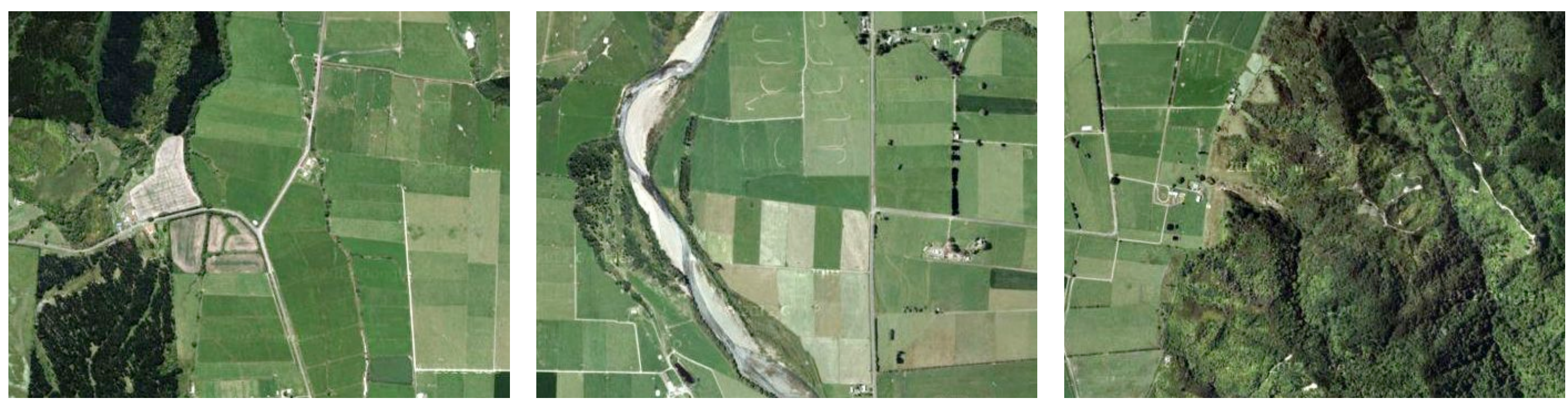

9.26 Confiscation Line: Aerial View. Ruatoki, New Zealand.

Retrieved from www.maps.google.co.nz 


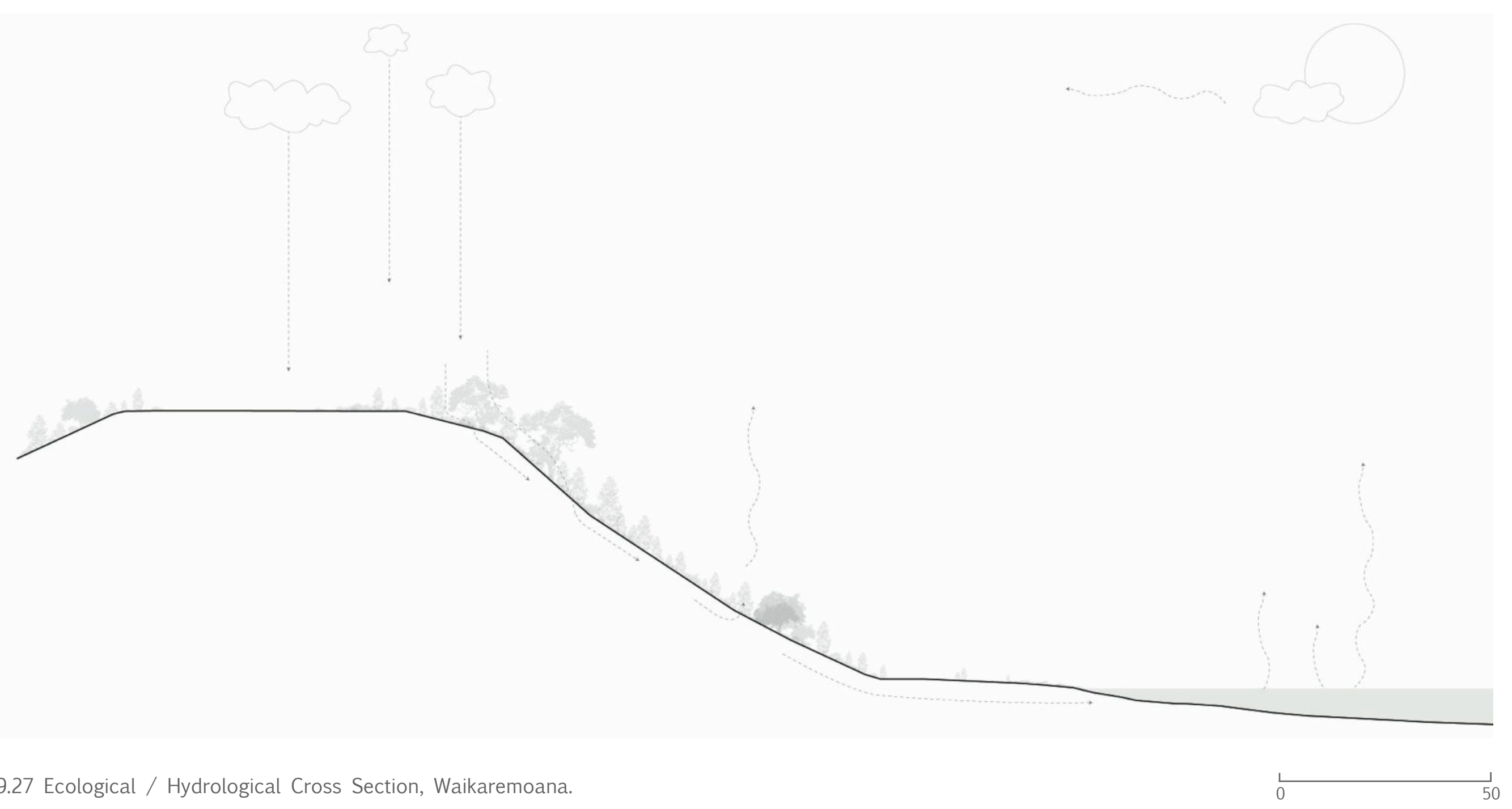



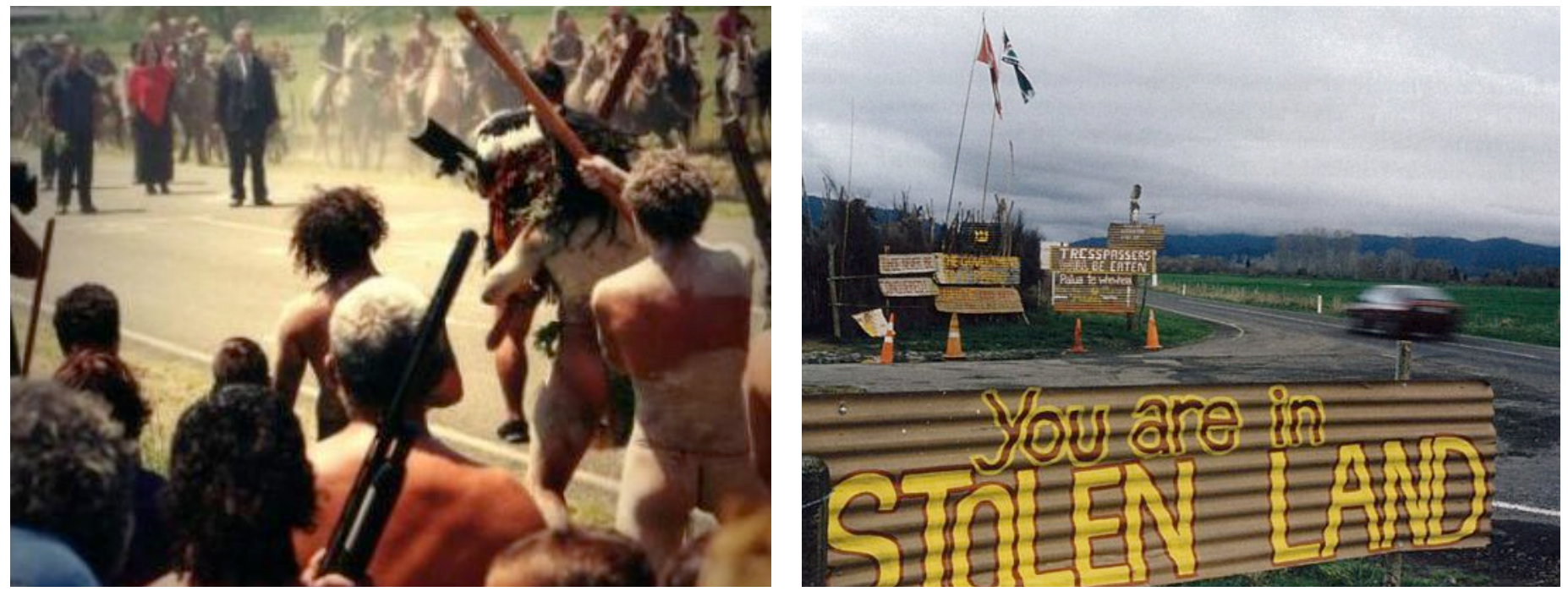

9.28 Protests during Waitangi tribunal along confiscation road. Ruatoki, New Zealand.

9.29 Painted signs at Ruatoki on the 1866 confiscaiton line. Ruatoki, New Zealand.

Still from Pouwhare, R. (Writer). (2005). Tuhoe, A History of Resistonce

In Binney, J. (2009). Encircled lands: Zealand: Bridget Williams Books.

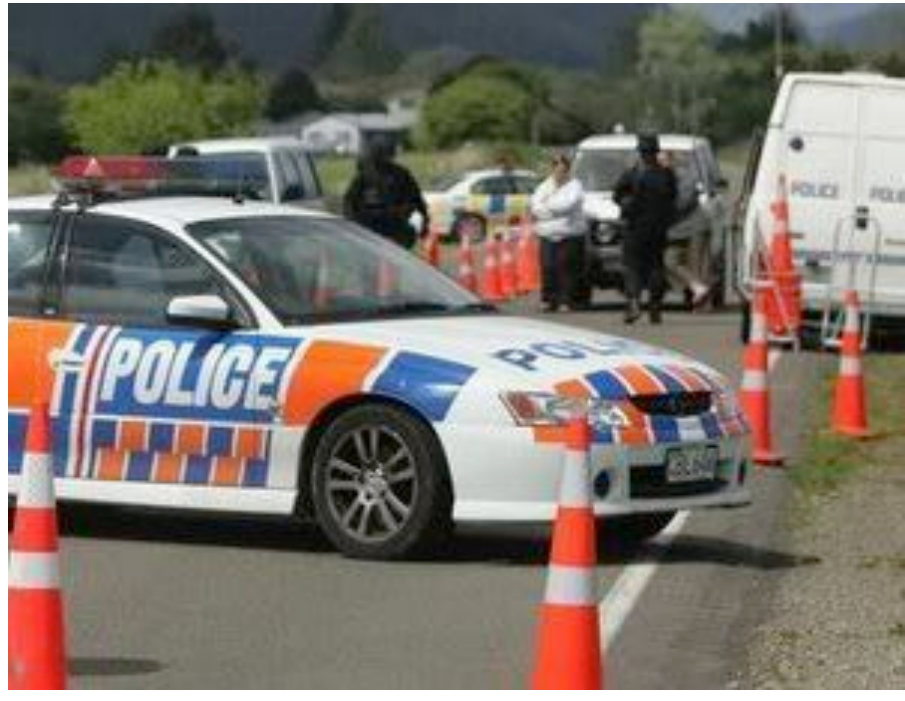

9.30 Armed police check vehicles at a roadblock in the Ruatoki Valley during the 2007 Terror Raids.

In Gibson, A. (2011 September 7). No apology over Urewera raids, The New Zealand Herald, retrieved from Newztext Plus database. 
Within the small Tūhoe community of Ruatoki, a widely unknown cutting intervention operates as a territorial marker in the landscape. In 1865, the Crown "drew a straight line" through Tūhoe's Rohe Potate (borders of control) commandeering their only substantial fertile land and their only access to the coast as punishment for collaborating with rebel forces (Keenan, 2008, p.211). Historically, a white line, known locally as the aukati line (to cut, to sever) was painted across the single road into the town - marking this cultural boundary. Since sealing the road, the centre line with the faded words 'CONFISCATION LINE' now mark this cultural site (Fig 9.25). Due to the fertility of the confiscated land, Tūhoe Chief Negotiator, Tamati Kruger has expressed that the landscape "literally changes" from one side of the line to the other (Thorby, 2012). Viewing the line from above (Fig 9.26) supports this claim. Reminiscent of De Maria's imposed boundary lines on the desert, this local intervention effectively constructs a linear ecological section along the aukati boundary.

Recent events have reanimated this now faded "marked site," for during the 2007 Terror Raids, police provokingly placed their roadblock across the line (Fig 9.30) - a symbolic intervention not lost upon the historically conscious Tūhoe tribe (Hill, 2010, p.1). Declaring, "The line is a frontier again," Binney (2009, p.604) argues that by placing their roadblock across this boundary, police effectively endorsed Tūhoe's Rohe Potate. Reinforced by these events, this severing line separates Tūhoe from Pakeha. A frontier for both parties, this line is a place of confrontation where cultures meet and negotiate - however violently this may be (Fig 9.28). Reflecting back on McCahon's depiction of road infrastructure within Te Urewera, here the cutting intervention provides not only a place to protest on, but a place to protest about. In this way the cut can be seen as provocative. Within contested landscapes such as Te Urewera, architectural interventions could exploit the confrontational qualities of the line and the cultural interactions it supports. Marking a cultural and ecological section through the Urewera landscape, this severing intervention encourages confrontational formal solutions that enhance the cultural conditions of the landscape. 


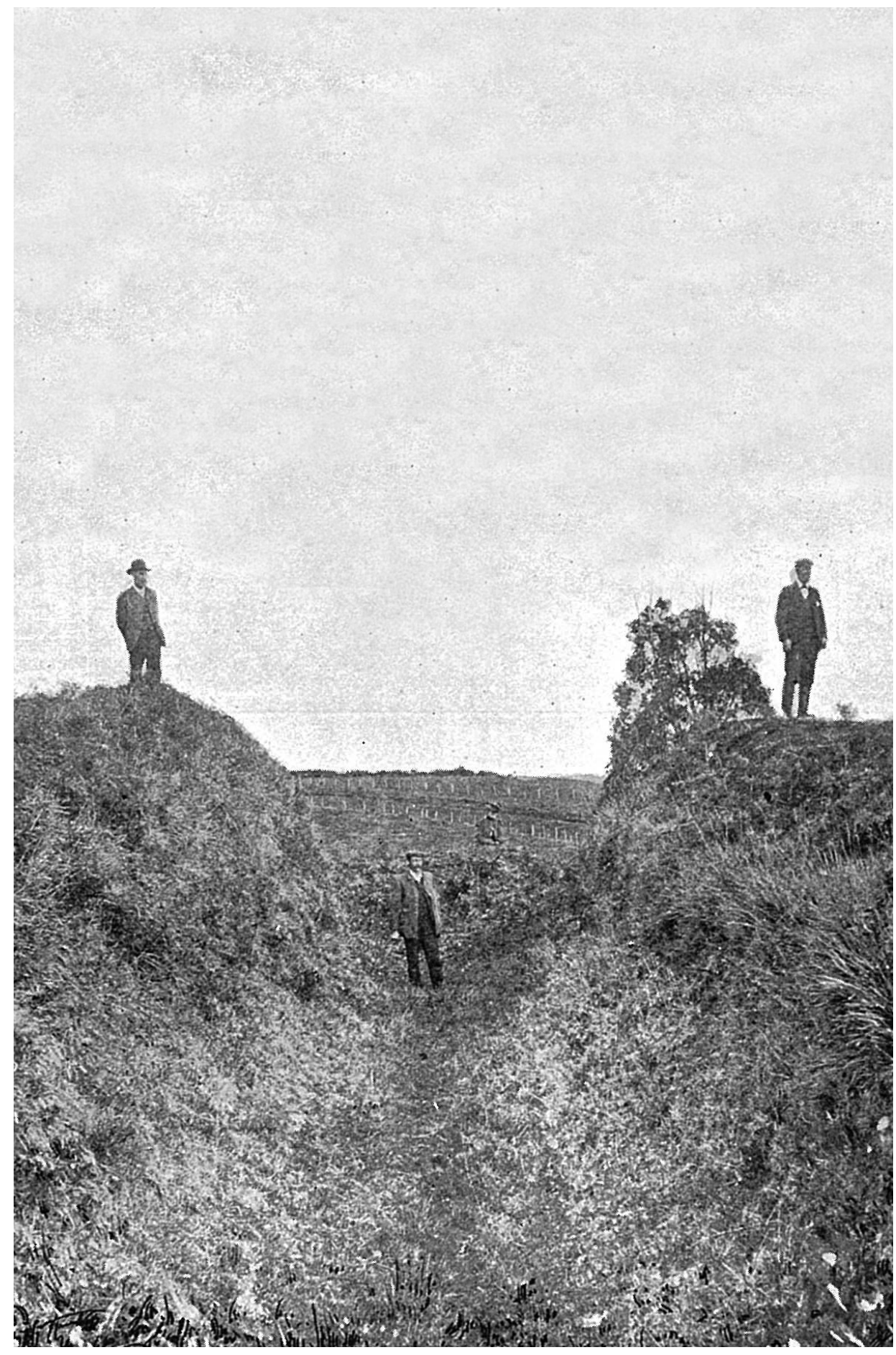

9.31 Remnants of unknown Maori pa. (n.d.)

In Best, E. (1975). The pa Maori: An account of the fortified villages of the Maori in pre-European and modern times, ilustrating methods of defense by means of ramparts, fosses, scarps and stockades. Wellington, New Zealand: Government Printer. 


\subsection{Defence Strategies:}

Māori defence structures, while not of relevance to Krauss's inquiry, offer cut-and-fill formal strategies for occupying the landscape. Although these pragmatic interventions lack the aesthetic considerations of the land-art examples - arguably failing to enhance the landscape - they can be examined for their ability to provide shelter from and within the natural environment.

Located profoundly throughout Te Urewera, Māori land alterations contrast with romantic perceptions of an untouched pre-European land. In reality, Māori significantly reshaped the landscape, with over 6000 "earthwork settlements" constructed throughout New Zealand. (Austin, n.d.) Broadly, the design of pa fell into two categories; the pa tuwatawata, in which the defences were largely limited to wooden palisades, and the pa whakairo, consisting of deep ditches, trenches and cuts in combination with pickets, palisades and ramparts. (Knight, 2009, p.13) Constructed through destructive action the aggressive land alteration of the pa whakairo is useful to this inquiry. Within the pa, further cutting of the land occurred in the form of wells, food storage pits, bomb-proof shelters, tunnels and rifle pits (Best, 1975). Cutting the land with a reliance on timber construction, rifle pits could be examined for their spatial content and situated alongside Perimeters / Pavilions / Decoys (Fig 9.32) in the category of "site construction." Today, remnants of these pa structures, existing as terraced impressions on the landscape, would appear to have shifted into a "marked site" operation (Fig 9.34). Despite these formal possibilities, discussion of these structures within the discipline is sparse. 

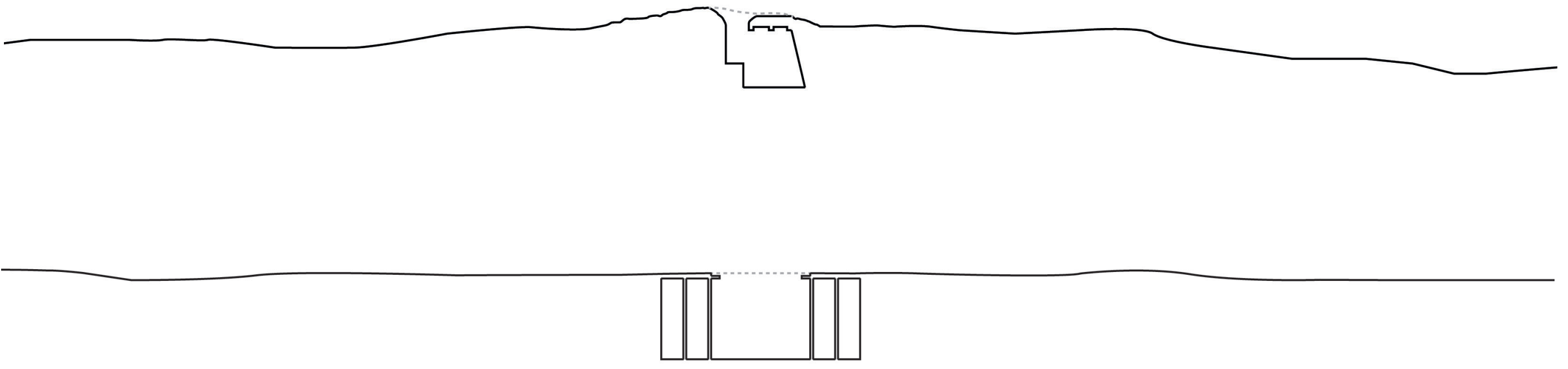

9.32 Cross Section Comparison of Maori Rifle Pit (Top) and Mary Miss's Perimeters/Pavilions/Decoys (Bottom).

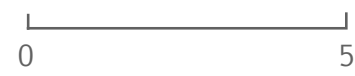



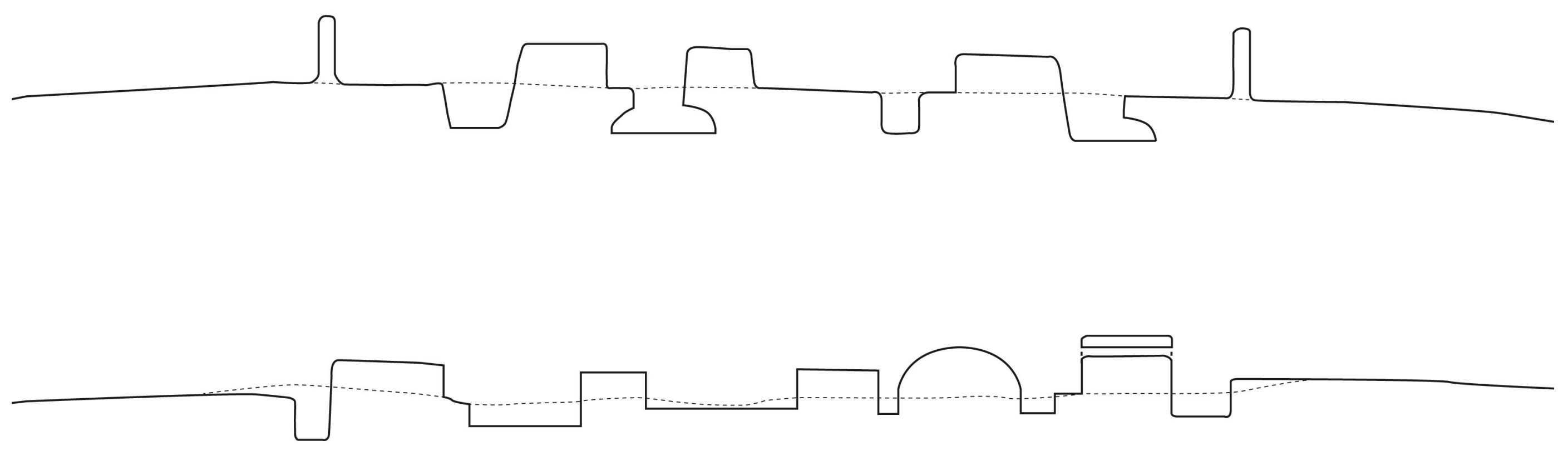

9.33 Cross Sections of Orakau Pa, (1864).

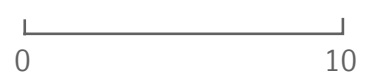




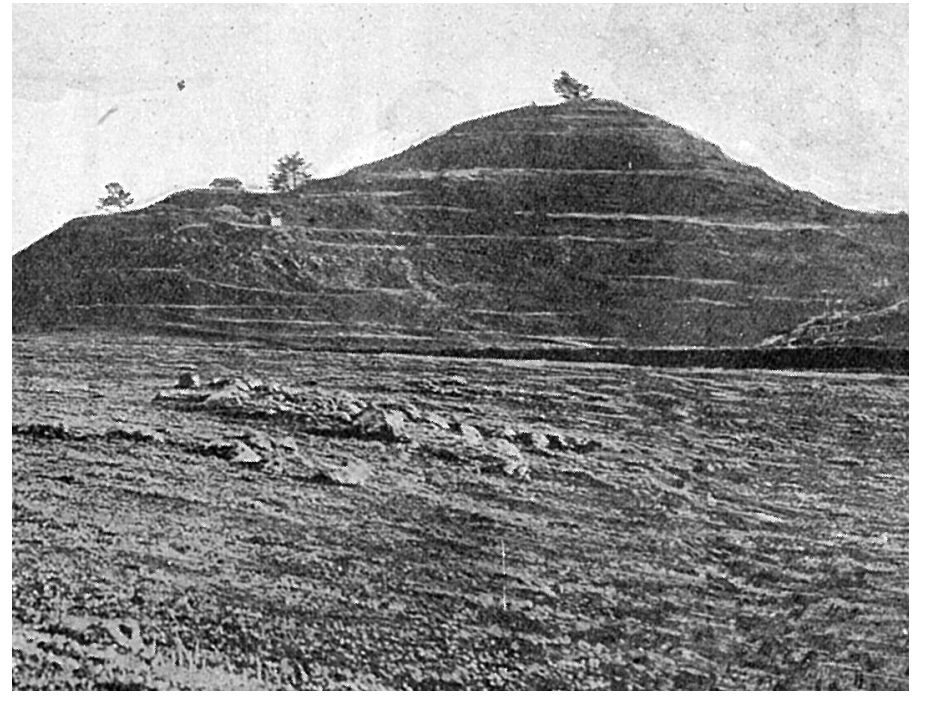

9.34 Terraced Remains of Maori Pa. Isthmas, Auckland, New Zealand.

In Best, E. (1975). The pa Maori: An account of the fortified villages of the Maori in pre-European and modern times, illustrating methods of defense by
means of ramparts, fosses, scarps and stockades. Wellington, New Zealand: Government Printer.

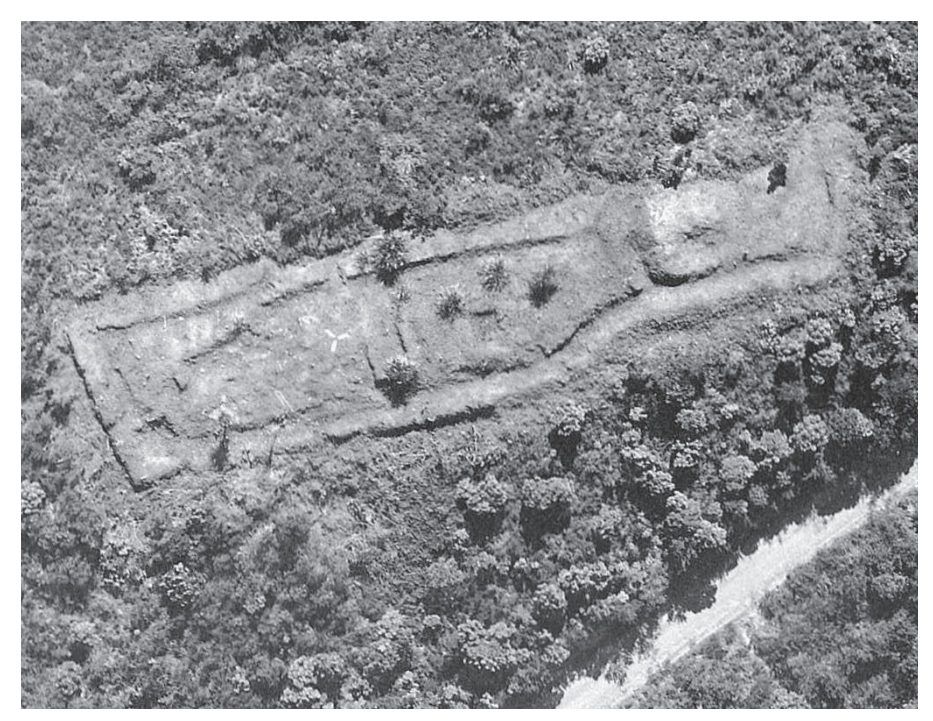

9.35 Te Tapiri Pa. (1865) Te Urewera, New Zealand. Retrieved from Retrieved from

http://nzetc.victoria.ac.nz/tm/scholarly/JonTohu-fig-

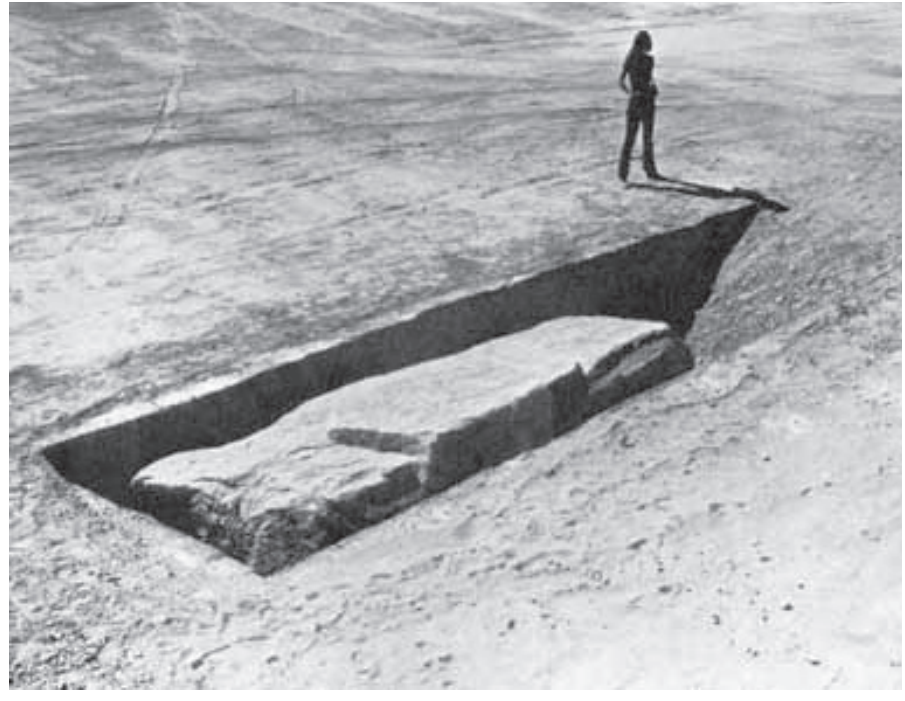

9.36 Heizer, M. (1969). Displaced-Replaced Mass. Silver Springs, Nevada, USA.

Retrieved from http://cartellogiallo.blogspot.co.nz/2012_01_01_archive.html 
Te Orakau pa (1864), constructed 150 miles outside Te Urewera, yet defended by predominantly Tūhoe fighters, offers useful cutand-fill formal strategies. Employing trenches and ramparts of up to four meters, the intervention was constructed from a destructive displacement of earth. Sharing a formal strategy with Heizer's Displaced/Replaced Mass (1969, Fig 9.36), this intervention is best analysed in cross section (Fig 9.33). Physically bunkering into the landscape, these cutting interventions provided secure inhabitation in an otherwise dangerous landscape. While we may no longer require protection from enemy tribes, we are still vulnerable to the unpredictable and overwhelming conditions of the natural environment. In this way, cutting the landscape provides opportunities to find refuge both from and within the natural environment. Neither invisible nor an aesthetic expense, this cut-and-fill strategy implies architecture and landscape could be approached as part of the same system. Encouraging formal solutions that enhance the qualities of both architecture and landscape, this cutting strategy also rethinks how we may find homeliness and comfort in the occupation of the landscape. 


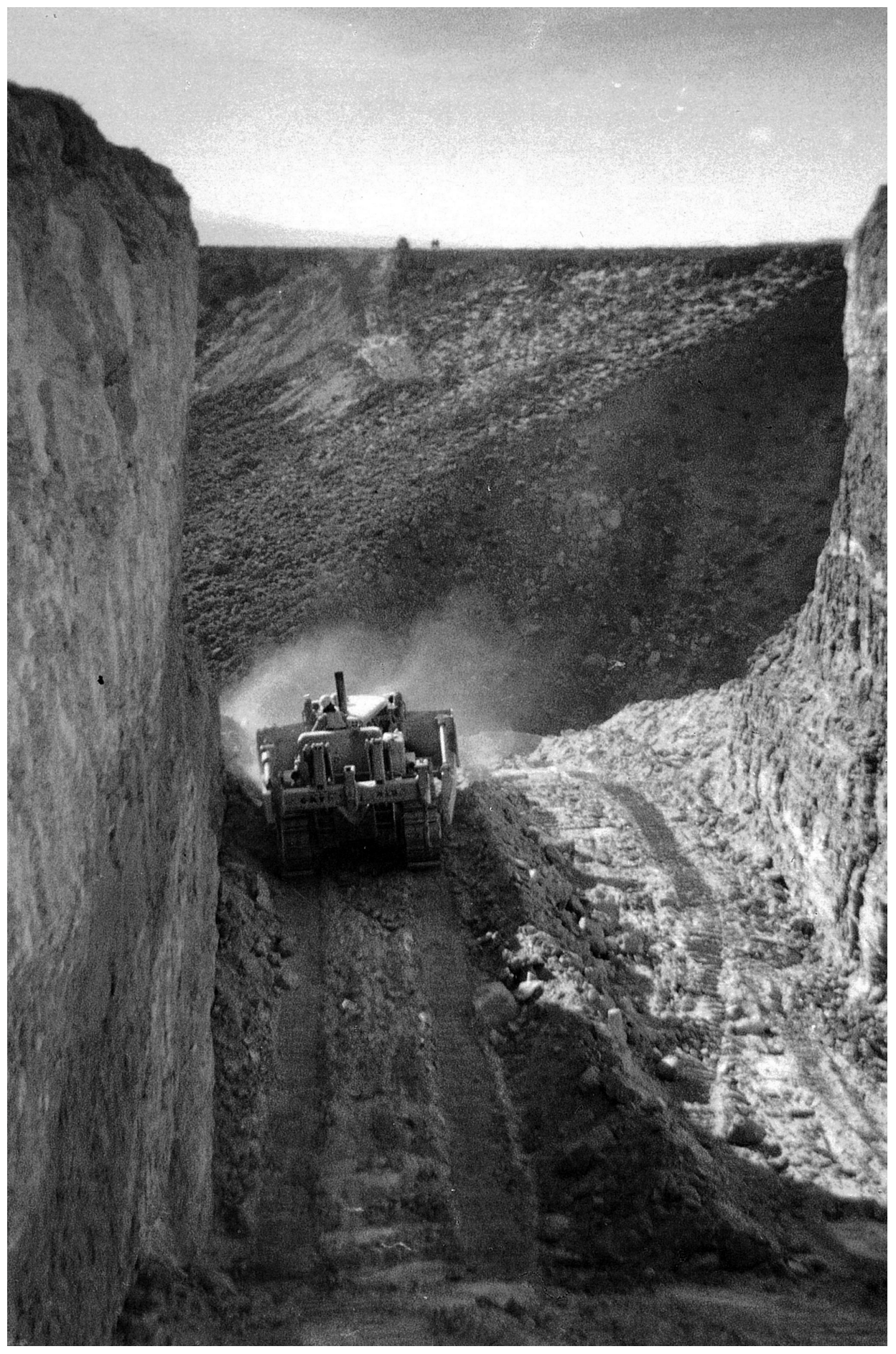

9.37 Heizer, M. (1970). Construction of Double Negative. Mormon Mesa, Nevada, USA.

In Celant, G. (1997). Michael Heizer. Milan, Italy: Fondazione Prada. 


\subsection{Construct/Destruct:}

Rethinking how we occupy the landscape, the Urewera interventions are all constructed through destructive action. This paradoxical formal strategy can also be observed in the land-art exemplars: each constructed through various degrees of destructive activity.

Displacing 240,000 tons of soil with the help of heavy construction corers, dynamite, backhoes, and bulldozers (Crone, 1982; Celant, 1997). Heizer's "Double Negative" is constructed through the destructive removal of earth (Fig 9.37-9). By dissecting the ground surface, subtracting mass, weight, and density, Heizer offers a brutal and oppositional response to the landscape. Violent alterations such as this were common throughout the land art movement with artist Robert Smithson (1996, p.102) suggesting; "the actual disruption of the earth's crust is at times very compelling." While this notion sits uncomfortably with today's ecologically sensitive approach to the landscape, it offers a productive formal inquiry to reconsider contemporary practice. Miss's Perimeters / Pavilions / Decoys was also constructed from a destructive cut in the landscape, however operates much differently to Heizer's unforgiving intervention. Sceptical of such monumentality (Abramson, 2007, p.34), Miss employs a small-scaled geometric incision on an open field. It is here that precision, not overwhelming scale, is utilized to enhance the landscape, as the artificial geometry composes a contradistinction with the natural landscape (Dekker, 1999, p.37) Constructed through various degrees of destructive action, both Heizer and Miss offer a cutting formal strategy that leverages the existing qualities of the landscape. 


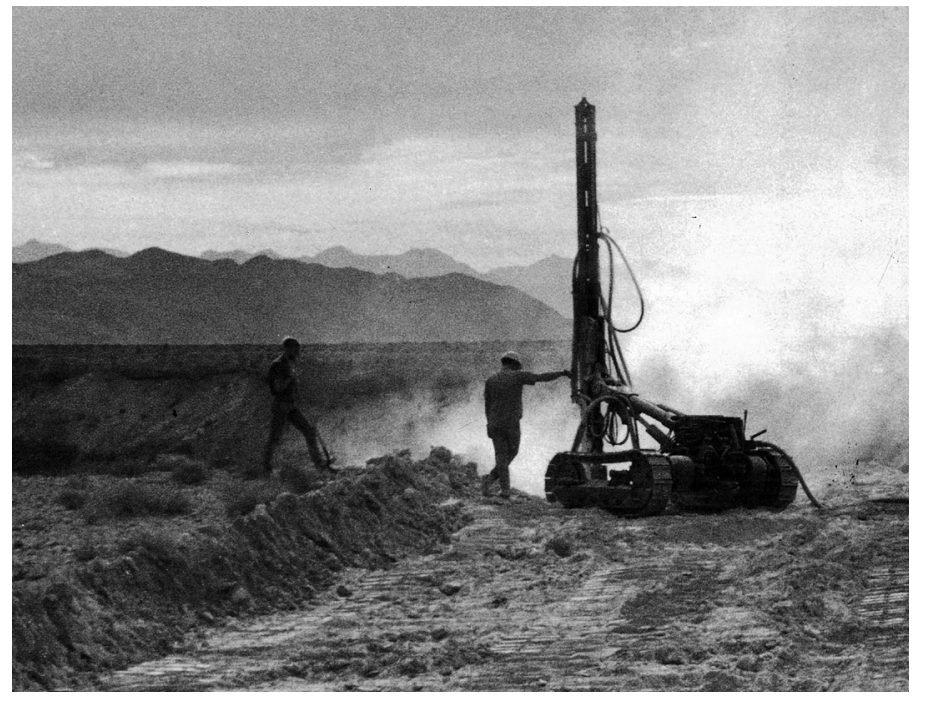

9.38 Heizer, M. (1970). Construction of Double Negative. Mormon Mesa, Nevada, USA.

In Celant, C. (1997). Michael Heizer. Milan, Italy: Fondazione Prada.

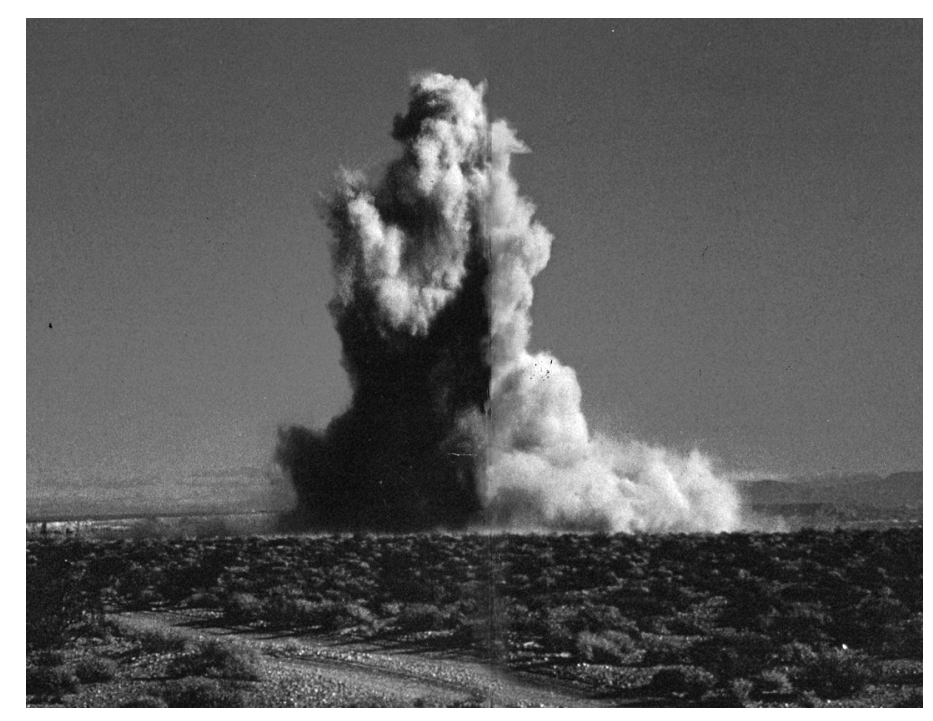

9.39 Heizer, M. (1970). Construction of Double Negative. Mormon Mesa, Nevada, USA.

In Celant, G. (1997). Michael Heizer. Milan, Italy: Fondazione Prada.

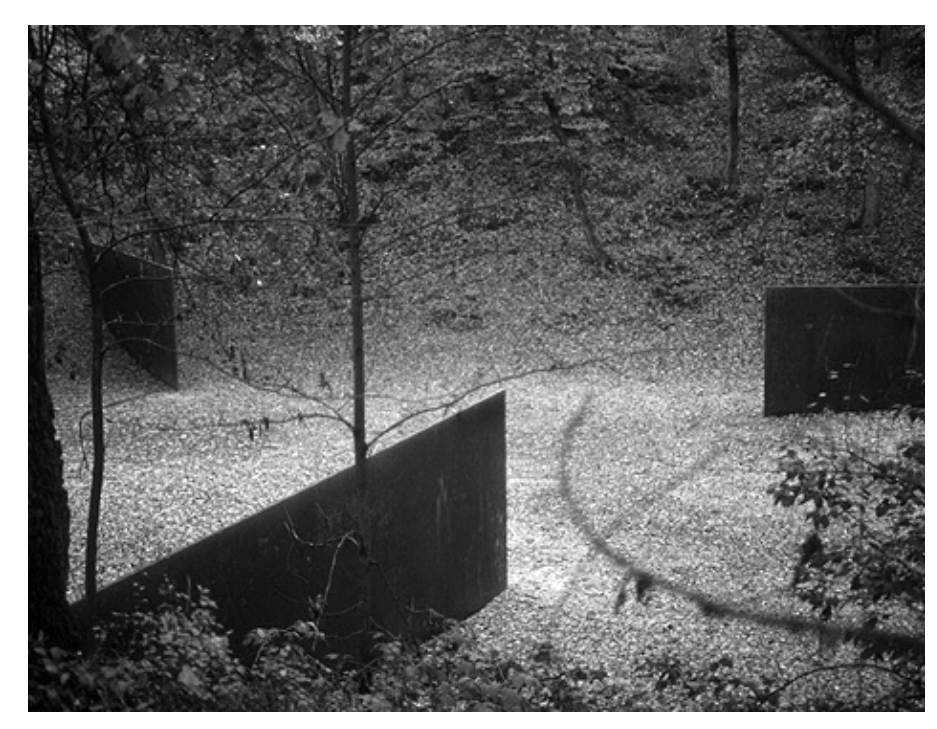

9.40 Serra, R. (1973). Spin Out (for Robert Smithson). Kröller-Müller Museum, The Netherlands.

Retrieved from http://public-art.shu.ac.uk/other/kroller/fi/0000003a.htm 
Richard Serra's Shift, also employs a constructive / destructive cutting operation on the landscape - albeit one of addition. Eisenman (1983, p.16) observes how the cutting operations of Shift and Spin Out (for Robert Smithson) (1973, Fig 9.40) are seen as substance, not void "constructing not figure/ground relationships, but rather constructing out of that ground." No longer viewed as background or foreground, this implies that architecture and landscape could be seen as part of the same system. Within precious landscapes, occupying form constructed through destructive action - such as a cut - offers largely unexplored opportunities to enhance the landscape. 


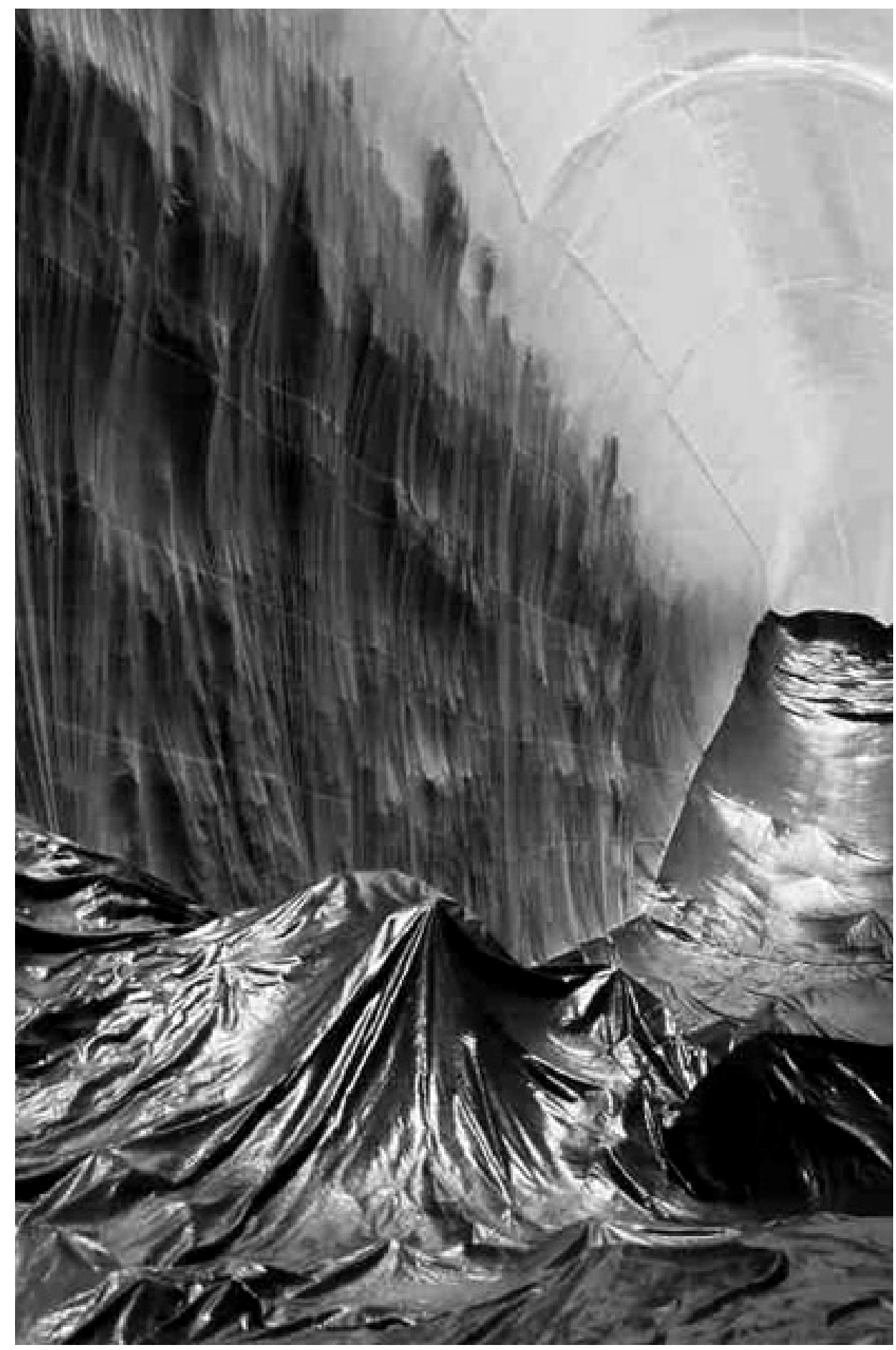

10.1 Landis, S. (2003). 'Air Check' in Double Negative, Mormon Mesa, Nevada, USA.

In Wieczorek, M. (2008). Life Raft in the Desert: Shawn Patrick Landis's Rendezvous with Double Negative. Sculpture, 27, 6. 


\subsection{Possibilities:}

Overbearing and timid architectural interventions continue to diminish our precious landscapes. However, several severing, dissecting and cutting land-art projects and interventions within Te Urewera unearth a constructed/destructed formal strategy that offers an alternative way forward. Providing connectivity, security and a place for confrontation, the cut offers a formal strategy that can be employed to enhance the dramatic qualities of the landscape.

Returning to Krauss's land-art interventions, Baker (1976, p.75) identifies that most of these projects operated on "culturally neutral" landscapes of the "desert" and the "open field." Driven by economic considerations, this conservative interest in bringing a landscape with a low profile up, rather than enhancing an already spectacular site appears to be a missed opportunity. As the service of an architect is typically required for building within spectacular - and expensive - sites, architects should take the opportunity to enhance such sites seriously. It is here that the Urewera interventions, operating within the largely untouched, yet highly contested landscape, gain heightened significance. In precious landscapes such as these, architectural interventions should boldly confront the natural environment, actively enhancing the aesthetic and overwhelming qualities of the landscape.

While this inquiry has reconsidered the occupation of our pristine national park landscapes, the implications are much wider, as the majority of our coastlines, mountains, hillsides and lakefronts are also pristine environments. Within many of these landscapes, local government employs anticipated contingencies that focus on mitigation rather than opportunism. Within the Queenstown - Lakes District Plan (2011) for example, proposed developments should "not be visible" or "reasonably difficult to see" (5.21), "should be sympathetic... following the natural lines of the landscape" (5.29) and "should not affect the naturalness of the landscape" (5.31). Driven to camouflage, miniaturize, and disperse, such restrictions encourage an inert architecture, apologetic for its own existence. Neither invisible nor an aesthetic expense, the cut encourages a confrontation with the natural environment - offering a productive formal strategy that could be employed to enhance both architecture and the landscape. 


\subsection{List of Figures}

Fig i. Perspective, Occupying the landscape: Arriving from lake (Day).

Fig ii. Lake House Hotel. (1901-1976). Waikaremoana, New Zealand. Retrieved from Alexander Turnbull Library, Ref: 1/2-040280-F. Wellington, New Zealand. http://natlib.govt.nz/records/23120741

\section{Part One: The Scheme}

Fig 1.1. Problem diagram, [Historic Development Failed to Enhance the Landscape] Unknown architect, (1901). The Lake House Hotel, Waikaremoana, New Zealand.

In Gallen, R. (1977). A souvenir booklet of Waikaremoana,Wairaumoana, Waikareiti: a concise history of the lakes, the people and the land. Hamilton, New Zealand: Urewera National Park Board.

Fig 1.2. Problem diagram, Access to Lake Waikaremoana. Created by author.

Fig 1.3. Problem diagram, Lake access from road. Created by author.

Fig 1.4. Problem diagram, Visitor / host disconnection. Created by author.

Fig 1.5. Problem diagram, Disconnection of host community from Lake Waikaremoana. Created by author.

Fig 1.6. Problem diagram, Cultural differences between local (70\% Māori) and visiting communities. Created by author.

Fig 1.7. Problem diagram, Disconnection between visitors and hosts within resort typology. Created by author.

Fig 1.8. Problem diagram, Visitor fluctuations within Te Urewera National Park. Created by author.

Fig 1.9. Problem diagram, [The tourist image of Waikaremoana] Unknown architect, (1901). The Lake House Hotel, Waikaremoana, New Zealand.

In Park, G. (2007). Theatre country: Essays on landscape and whenua. Wellington, New Zealand: Victoria University Press.

Fig 1.10. Location diagram, Te Urewera National Park.

Retrieved from www.maps.google.co.nz.

Fig 1.11. Location diagram, Lake Waikaremoana.

Retrieved from www.maps.google.co.nz.
Fig 1.12. Location diagram, Home Bay. Retrieved from www.maps.google.co.nz.

Fig 1.13. Location diagram, Site diagram. Created by author.

Fig 1.14. Concept diagram, A cut in the landscape. Created by author. Fig 1.15. Section (1:1000), Section A-A. Created by author.

Fig 1.16. Plan (1:1000), Location plan. Created by author.

Fig 2.1. Perspective, Occupying the landscape: Arriving from lake (Night). Created by author.

Fig 2.2. Diagram, Occupying the landscape. Created by author.

Fig 2.3. Perspective, Occupying the landscape: Entrance from Lake Road (State Highway 38). Created by author.

Fig 2.4. Perspective, Occupying the landscape: Home Bay Hill view. Created by author.

Fig 2.5. Perspective, Occupying the landscape: Entrance from lake. Created by author.

Fig 2.6. Section (1:500), Section A-A. Created by author.

Fig 2.7. Plan (1:500), Site plan. Created by author

Fig 2.8. Section (1:500), Section B-B. Created by author.

Fig 2.9. Section (1:500), Section C-C. Created by author.

Fig 2.10. Section (1:500), Section D-D. Created by author.

Fig 2.11. Section (1:500), Section E-E. Created by author.

Fig 3.1. Perspective, Occupying the cut: Lake transect. Created by author.

Fig 3.2. Diagram, Occupying the cut. Created by author.

Fig 3.3. Perspective, Occupying the cut: Traverse theatre and outdoor dining on canopy extension. Created by author.

Fig 3.4. Perspective, Occupying the cut: Looking up cut. Created by author.

Fig 3.5. Perspective, Occupying the cut: Looking down cut. Created by author.

Fig 3.6. Perspective, Occupying the cut: Reception lobby looking towards Panekeri Bluff. Created by author.

Fig 3.7. Perspective, Occupying the cut: Social cross section through lift. Created by author.

Fig 3.8. Perspective, Occupying the cut: Observation tower looking to 
locally significant Maungapohatu. Created by author.

Fig 3.9. Section (1:200), Section D-D, Tower Callout. Created by author.

Fig 3.10. Plan (1:200), Reception plan. Created by author.

Fig 3.11. Section (1:200), Section E-E, Central Callout. Created by author.

Fig 3.12. Plan (1:200), Lecture theatre plan. Created by author.

Fig 3.13. Section (1:200), Section D-D, Canopy Extension Callout. Created by author.

Fig 3.14. Plan (1:200), Upper dining \& outdoor theatre plan. Created by author.

Fig 4.1. Perspective, Occupying the resort: North façade with public porches and private balconies. Created by author.

Fig 4.2. Diagram, Occupying the resort. Created by author.

Fig 4.3. Perspective, Occupying the resort: Executive suite, (Unit 4.11). Created by author.

Fig 4.4. Perspective, Occupying the resort: Executive suite (Unit 4.11), Looking up light chimney. Created by author.

Fig 4.5. Perspective, Occupying the resort: Executive suite, (Unit 4.11), Looking through pivoting panel towards bush. Created by author.

Fig 4.6. Perspective, Occupying the resort: Two-bedroom tower suite, (Unit 4.15), Living space. Created by author.

Fig 4.7. Perspective, Occupying the resort: Two-bedroom tower suite, (Unit 4.15), Master bedroom. Created by author.

Fig 4.8. Cross Section (1:200), Section F-F. Created by author.

Fig 4.9. Cross Section (1:200), Section G-G. Created by author.

Fig 4.10. Axonometric, Executive suite, (Unit 4.11). Created by author. Fig 4.11. Plan (1:200), Executive suite, (Unit 4.11). Created by author.

Fig 4.12. Axonometric, Three-bedroom deluxe suite, (Unit 4.13). Created by author.

Fig 4.13. Plan (1:200), Three-bedroom deluxe suite, (Unit 4.13). Created by author.

Fig 4.14. Axonometric, Two-bedroom tower suite, (Unit 4.15). Created by author.

Fig 4.15. Plan (1:200), Two-bedroom tower suite, (Unit 4.15). Created by author.

Fig 5.5. Density diagram, Waikaremoana scheme, Created by author.
Fig 5.6. Diagram, Initial response: The cut. Created by author.

Fig 5.7. Process drawing, Cutting the landscape. Created by author.

Fig 5.8. Process drawing, Three tower scheme. Created by author.

Fig 5.9. Process drawing, Linear strip scheme. Created by author.

Fig 5.10. Process drawing, Tower modeling. Created by author.

Fig 5.11. Diagram, Occupying the cut: Replaced mass. Created by author.

Fig 5.12. Process drawing, Replaced mass. Created by author.

Fig 5.13. Process drawing, Replaced mass Section. Created by author.

Fig 5.14. Process model, Replaced mass model 1. Created by author.

Fig 5.15. Process model, Replaced mass model 2. Created by author.

Fig 5.16. Diagram, Occupying the cut: Displaced mass. Created by author.

Fig 5.17. Process drawing, Displaced mass. Created by author.

Fig 5.18. Process drawing, Displaced mass Section. Created by author. Fig 5.19. Process model, Displaced mass model 1. Created by author. Fig 5.20. Process model, Displaced mass model 2. Created by author. Fig 5.21. Diagram, Occupying the Cut: The Void. Created by author. Fig 5.22. Perspective, Looking up cut. Created by author.

Fig 5.23. Plan, Waikaremoana scheme. Created by author.

Fig 5.24. Before intervention, Waikaremoana Scheme. Created by author.

Fig 5.25. After intervention, Waikaremoana Scheme. Created by author. 


\section{Part Two: The Paper}

Fig 6.1. Richard Legorreta. (1981). Hotel Camino Real. Ixtapa, Mexico. Retrieved from http://cybertesis.upc.edu.pe/upc/2003/moreyra_as/ html/TH.3.html

Fig 6.2. Foster + Partners. (2005). Green Mountain Canyon resort. Libya.

Retrieved from http://danielepetteno.com/practice/danielepetteno/ experience/collaborationworks/greenmountaincanyonresort.html

Fig 6.3. King - Rosilli (2007). Club Med Cefalu [Figure/ground diagram]. Sicily, Italy.

Created by author.

Fig 6.4. Diagram, 1865: Tūhoe's Rohe Potae Border

Created from author from Harris, A. (1993). Crown Acquisition of Confiscated and Māori Land in Taranaki, 1872-188. Waitangi Tribunal research series, no. 1 .

Fig 6.5. Diagram, 1910: The Urewera District Native Reserve

Created from author from Harris, A. (1993). Crown Acquisition of Confiscated and Māori Land in Taranaki, 1872-188. Waitangi Tribunal research series, no. 1.

Fig 6.6. Diagram, 2012: The Urewera National Park

Created from author from Harris, A. (1993). Crown Acquisition of Confiscated and Māori Land in Taranaki, 1872-188. Waitangi Tribunal research series, no. 1 .

Fig 7.1. Richard Legorreta (1981). Hotel Camino Real [Figure/ground diagram]. Ixtapa, Mexico.

Created by author.

Fig 7.2. Richard Legorreta (1981). Hotel Camino Real [Before Diagram]. Ixtapa, Mexico.

Retrieved from http://flickr.com/photos/erick_m_photo/6603968255/ in/photostream

Fig 7.3. Richard Legorreta (1981). Hotel Camino Real [After diagram]. Ixtapa, Mexico.

Created by author using Fig 7.3.

Fig 7.4. Hall \& McKenzie. (1957). The Hermitage Hotel [Figure/ground diagram]. Mount Cook, New Zealand.

Created by author.

Fig 7.5. Hall \& McKenzie. (1957). The Hermitage Hotel [Before Diagram]. Mount Cook, New Zealand.

Retrieved from http://hermitage.co.nz/en/trade-and-media

Fig 7.6. Hall \& McKenzie. (1957). The Hermitage Hotel [After diagram]. Mount Cook, New Zealand.

Created by author using Fig 7.5.
Fig 7.7. Architect Unknown. (1962). Copthorne Hotel [Figure/ground diagram]. Waitangi, New Zealand.

Fig 7.8 Hallen, A. (1833). Treaty House [Cultural landscape of the treaty grounds]. Waitangi, New Zealand.

Retrieved from http://cosgrove.school.nz/nzthings.html

Fig 7.9. Architect Unknown. (1962). Copthorne Hotel [Proximity of hotel to treaty grounds]. Waitangi, New Zealand.

Retrieved from http://moatrek.co.nz/tours/northland/

Fig 7.10. Foster + Partners. (2005). Green Mountain Canyon Resort [Figure/ground diagram]. Libya.

Created by author.

Fig 7.11. Foster + Partners. (2005). Green Mountain Canyon Resort [Before Diagram]. Libya.

Retrieved from http://danielepetteno.com/practice/danielepetteno/ experience/collaborationworks/greenmountaincanyonresort.html

Fig 7.12. Foster + Partners. (2005). Green Mountain Canyon Resort [After diagram]. Libya.

Created by author using Fig 7.11.

Fig 7.13. King - Rosilli. (2007). Club Med Cefalu [Figure/ground diagram]. Sicily, Italy.

Created by author.

Fig 7.14. King - Rosilli. (2007). Club Med Cefalu [Before Diagram]. Sicily, Italy.

Retrieved from: http://europaconcorsi.com/projects/1874-Club-MedCefal-/print

Fig 7.15. King - Rosilli. (2007). Club Med Cefalu [After diagram]. Sicily, Italy.

Created by author using Fig 7.14.

Fig 7.16. Graciastudio. (2011). Endemico Resguardo Silvestre [Figure/ ground diagram]. Ensenada, Mexico.

Created by author.

Fig 7.17. Graciastudio. (2011). Endemico Resguardo Silvestre [Before Diagram]. Ensenada, Mexico.

Retrieved from http://graciastudio.com/Projects/Comercial/Endemico/endemico.html

Fig 7.18. Graciastudio. (2011). Endemico Resguardo Silvestre [After diagram]. Ensenada, Mexico.

Created by author using Fig 7.17.

Fig 7.19. Various Architects. (1993-2012). Millbrook Resort [Figure/ ground diagram]. Arrowtown, New Zealand.

Created by author.

Fig 7.20. Various Architects. (1993-2012). Millbrook Resort [Before Diagram]. Arrowtown, New Zealand.

Retrieved from http://asiarooms.com/en/new_zealand/ queenstown/174665-millbrook_resort.html 
Fig 7.21. Various Architects. (1993-2012). Millbrook Resort [After diagram]. Arrowtown, New Zealand.

Created by author using Fig 7.20.

Fig 8.1. Tezuka Architects. (2006). Matsunoyama Natural Science Museum [Figure/ground diagram]. Niigata, Japan.

Created by author.

Fig 8.2. Tezuka Architects. (2006). Matsunoyama Natural Science Museum [Before Diagram]. Niigata, Japan.

Retrieved from http://flickr.com/photos/76223770@N00/56831457/

Fig 8.3. Tezuka Architects. (2006). Matsunoyama Natural Science Museum [After diagram]. Niigata, Japan.

Created by author using Fig 8.2.

Fig 8.4. OMA. (2006). Jebel al Jais Mountain Resort [Figure/ground diagram]. Ras Al Khaimah, United Arab Emirates.

Created by author.

Fig 8.5. OMA. (2006). Jebel al Jais Mounta

in Resort [Before Diagram]. Ras Al Khaimah, United Arab Emirates.

Retrieved from http://oma.eu/projects/2006/jebel-al-jais-mountainresort

Fig 8.6. OMA. (2006). Jebel al Jais Mountain Resort [After diagram]. Ras Al Khaimah, United Arab Emirates.

Created by author using Fig 8.5 .

Fig 8.7. Architecture Workshop. (2004). Peregrine Winery [Figure/ ground diagram]. Gibbston Valley, New Zealand.

Created by author.

Fig 8.8. Architecture Workshop. (2004). Peregrine Winery [Before Diagram]. Gibbston Valley, New Zealand.

In Reynolds, P. (2004). Grape expectations. Architectural Review, 216 (1294, p47.

Fig 8.9. Architecture Workshop. (2004). Peregrine Winery [After diagram]. Gibbston Valley, New Zealand.

Created by author using Fig 8.8.

Fig 8.10. Kuma, K. (1994). Kiro-San Observatory [Figure/ground diagram]. Ehime, Japan.

Created by author.

Fig 8.11. Kuma, K. (1994). Kiro-San Observatory [Before Diagram]. Ehime, Japan.

Retrieved from http://archilab.org/public/2000/architec/visites/ kengo01.htm

Fig 8.12. Kuma, K. (1994). Kiro-San Observatory [After diagram]. Ehime, Japan.

Created by author using Fig 8.11.

Fig 8.13. Heizer, M. (1969). Double Negative [Figure/ground diagram]. Nevada desert, USA.

Created by author.
Fig 8.14. Heizer, M. (1969). Double Negative [Before Diagram]. Nevada desert, USA.

In Celant, G. (1997). Michael Heizer. Milan, Italy: Fondazione Prada.

Fig 8.15. Heizer, M. (1969). Double Negative [After diagram]. Nevada desert, USA.

Created by author using Fig 8.15.

Fig 8.16. New Zealand Public Works Department. (1929-1943).Waikaremoana Power Scheme [Figure/ground diagram]. Waikaremoana, New Zealand.

Created by author

Fig 8.17. New Zealand Public Works Department. (1929-1943).Waikaremoana Power Scheme [Before Diagram]. Waikaremoana, New Zealand. Retrieved from Whites Aviation Ltd: Photographs. Ref: WA-46437-G. Alexander Turnbull Library, Wellington, New Zealand. http://natlib.govt. $\mathrm{nz} /$ records/22399952

Fig 8.18. New Zealand Public Works Department.(1929-1943).Waikaremoana Power Scheme [After diagram]. Waikaremoana, New Zealand. Created by author using Fig 8.17.

Fig 9.1. Krauss, R. (1979). Sculpture in the Expanded Field. October, 8 (Spring).

9.2 De Maria, W. (1969) Las Vegas Piece. Desert Valley, Nevada, USA. In Kastner, J. \& Wallis, B. (1998). Land and environmental art. London, England: Phaidon.

9.3 Heizer, M. (1970). Double Negative. Mormon Mesa, Nevada, USA. In Celant, G. (1997). Michael Heizer. Milan, Italy: Fondazione Prada.

9.4 Heizer, M. (1970). Double Negative. Mormon Mesa, Nevada, USA. In Celant, G. (1997). Michael Heizer. Milan, Italy: Fondazione Prada.

9.5 Miss, M. (1978). Perimeters/Pavilions/Decoys. Nassau County Museum of Fine Arts, New York, USA.

In Abramson, D. (2002). Mary Miss. New York, USA: Princeton Architectural.

9.6 Serra, R. (1972). Shift. King City, Canada.

Retrieved from http://historyofourworld.wordpress.com/2008/12/11/ shift-1970-1972-richard-serra/

9.7 Serra, R. (1972). Shift. King City, Canada.

Retrieved from http://slowpainting.wordpress.com/2008/02/02/richard-serrarobert-smithson-continuum/

Fig 9.8. Bhatia, N., InfraNet Lab (Firm) \& Lateral Office (Firm). (2011). Infrastructure in the Expanded Field.

In Coupling: Strategies for infrastructural opportunism. New York, USA: Princeton Architectural Press.

Fig 9.14. Neufeld, D. (2011). [Cutting Road Operation at Waikaremoana] Retrieved from http://yukonrambles.blogspot.co.nz/2011/12/rangitaiki-river-and-ruatahuna.html 
Fig 9.16. Malcolm, R. (1904). On the mountain track to Te Whaiti. Retrieved from Ranfurly family: Photographs. Ref: PA1-q-634-23. Alexander Turnbull Library, Wellington, New Zealand. http://natlib.govt.nz/ records/22916582

Fig 9.17. Couldrey, J. (2011). Slip, Old Ruatahuna Road. Retrieved from http://agathering.co.nz/jennys_gallery/page/5/article/43/

Fig 9.18. McCahon, C. (1975). Urewera Mural. Acrylic on cotton duck, Auckland Art Gallery, on loan from the Department of Conservation Te Papa Atawhai.

Retrieved from http://aucklandartgallery.com/the-collection/browseartwork/15676/urewera-mural

Fig 9.19. Diagram, Road section at Waikaremoana. Waikaremoana Road.

Created by author.

Fig 9.20. New Zealand Public Works Department. (1929-1943).Waikaremoana Power Scheme. Waikaremoana, New Zealand.

Retrieved from Whites Aviation Ltd: Photographs. Ref: WA-46437-G. Alexander Turnbull Library, Wellington, New Zealand. http://natlib.govt. $\mathrm{nz} /$ records/22399952

Fig 9.21. New Zealand Public Works Department. (1929-1943). Surge Chamber. Waikaremoana, New Zealand.

In Natusch, G. (1992). Power from Waikaremoana: a history of Waikaremoana hydro-electric power development. Tuia, New Zealand: Electricorp Production.

Fig 9.22. New Zealand Public Works Department. (1929-1943). Penstocks. Waikaremoana, New Zealand.

In Genesis Power Limited. (2012). Waikaremoana Power Scheme, Annual Environmental Report - 1 July 2011 to 30 June 2012. Tokaanu, New Zealand: Genesis Energy.

Fig 9.23. New Zealand Public Works Department. (1929-1943). Construction of power house pipeline. Waikaremoana, New Zealand.

In Natusch, G. (1992). Power from Waikaremoana: a history of Waikaremoana hydro-electric power development. Tuia, New Zealand: Electricorp Production.

Fig 9.24. Diagram, Section of Waikaremoana power scheme.

Created by author.

Fig 9.25. Confiscation line: Google Street-view outside Ruatoki. Ruatoki, New Zealand.

Retrieved from www.maps.google.co.nz

Fig 9.26. Confiscation line: Aerial view. Ruatoki, New Zealand. Retrieved from www.maps.google.co.nz

Fig 9.27. Diagram, Ecological / hydrological cross section of lake Waikaremoana.

Created by author.
Fig 9.28. Pouwhare, R. (2005) Protests during Waitangi tribunal along confiscation road. Ruatoki, New Zealand.

Still from Pouwhare, R. (Director). (2005). Tuhoe, A History of Resistance. In G. Tatham (Producer). New Zealand: Tan $\neg$ gata Whenua Television Ltd.

Fig 9.29. Binney, J. (2009). Painted signs àt Ruatoki on the 1866 confiscation line. Ruatoki, New Zealand.

In Binney, J. (2009). Encircled lands: Te Urewera 1820-1921. Wellington, New Zealand: Bridget Williams Books.

Fig 9.30. Gibson, A. (2007). Armed police check vehicles at a roadblock in the Ruatoki Valley during the 2007 Operation eight raids. In Gibson, A. (2011 September 7). No apology over Urewera raids, The New Zealand Herald, retrieved from Newztext Plus database.

Fig 9.31. Unknown Photographer, (n.d.). Remnants of Māori Pa. In Best, E. (1975). The pa Māori: An account of the fortified villages of the Māori in pre-European and modern times, illustrating methods of defense by means of ramparts, fosses, scarps and stockades. Wellington, New Zealand: Government Printer.

Fig 9.32. Diagram, Cross section comparison of Māori rifle pit and Perimeters/Pavilions/Decoys (Mary Miss, 1978).

Created by author.

Fig 9.33. Diagram, Cross sections of Orakau Pa. (1864.).

Created by author from Best, E. (1975). The pa Māori: An account of the fortified villages of the Māori in pre-European and modern times, illustrating methods of defense by means of ramparts, fosses, scarps and stockades. Wellington, New Zealand: Government Printer.

Fig 9.34. Terraced remains of Māori Pa, Isthmas, Auckland, New Zealand.

In Best, E. (1975). The pa Māori: An account of the fortified villages of the Māori in pre-European and modern times, illustrating methods of defense by means of ramparts, fosses, scarps and stockades. Wellington, New Zealand: Government Printer.

Fig 9.35. Unknown Photographer, (n.d.). Te Tapiri. (1865)

Retrieved from http://nzetc.victoria.ac.nz/tm/scholarly/JonTohu-figJonTohu134a.html

Fig 9.36. Heizer, M. (1969). Displaced-Replaced Mass. Silver Springs, Nevada, USA.

Retrieved from http://cartellogiallo.blogspot.co.nz/2012_01_01_archive. html

9.37. Heizer, M. (1970). Double Negative [Construction Process]. Mormon Mesa, Nevada, USA.

In Celant, G. (1997). Michael Heizer. Milan, Italy: Fondazione Prada.

9.38. Heizer, M. (1970). Double Negative [Construction Process] Mormon Mesa, Nevada, USA.

In Celant, G. (1997). Michael Heizer. Milan, Italy: Fondazione Prada. 
9.39. Heizer, M. (1970). Double Negative [Construction Process]. Mormon Mesa, Nevada, USA.

In Celant, G. (1997). Michael Heizer. Milan, Italy: Fondazione Prada.

9.40. Serra, R. (1973). Spin Out (for Robert Smithson). Kröller-Müller Museum, The Netherlands

Retrieved from http://public-art.shu.ac.uk/other/kroller/fi/0000003a. htm

Fig 10.1. Landis, S. (2003). Air Check in Double Negative. Mormon Mesa, Nevada, USA.

In Wieczorek, M. (2008). Life Raft in the Desert: Shawn Patrick Landis's Rendezvous with Double Negative. Sculpture, 27, 6. 


\subsection{Reference List:}

Abramson, D. (2002). Mary Miss. New York, USA: Princeton Architectural.

Adjaye, D. (2012). Authoring: re-placing art and architecture. Zurich, Switzerland: Princeton School of Architecture.

Allen, S. (2010). Landscape infrastructures. In Stoll, K. \& Lloyd, S. (eds). Infrastructure as Architecture: designing composite networks (pp 64-76). Berlin, Germany: Jovis.

Austin, M. (n.d). Landscape and the New Zealand Māori. Unpublished paper, University of Auckland School of Architecture. cited in Wood, P. (2000). Trespassers will be Eaten: The Māori Land Occupation Structures of Waikaremoana. in Ostwald, J. \& Moore, R. (eds). Re-framing architecture: theory, science and myth. Sydney, Australia: Archadia Press.

Baker, E. (1976). Artworks on the land. Art in America, 64, pp.92-96.

Bekirogle, S. \& Gipser, O. (2008). Rethinking the all-inclusive. Berlage Institute Research Report, 18, Rotterdam: Berlage Institute.

Best, E. (1975). The pa Māori: An account of the fortified villages of the Māori in pre-European and modern times, illustrating methods of defense by means of ramparts, fosses, scarps and stockades. Wellington, New Zealand: Government Printer.

Bijlsma, L. (2004). Architecture and the tourist landscape. OASE, 64, pp. 2-16.

Binney, J. (1995). Redemption songs: a life of Te Kooti Arikirangi Te Turuki. Auckland, New Zealand: Auck $\neg$ land University Press.

Binney, J. (2009). Encircled lands: Te Urewera 1820-1921. Wellington, New Zealand: Bridget Williams Books.

Bhatia, N., InfraNet Lab (Firm) \& Lateral Office (Firm). (2011). Coupling: Strategies for infrastructural opportunism. New York, USA: Princeton Architectural Press.

Brady, E. (2010). The sublime, ugliness and "terrible beauty" in Icelandic landscape. In Benediktsson,K. \& Lund, K. (eds). Conversations with landscape (pp. 125-137). Burlington, USA: Ashgate Publishers.

Brees, S. (1847). Pictorial illustrations of New Zealand. London, England: John Williams and Co.

Campbell, S. (1999). Urewera overview project four: Te Urewera national park 1952-1975. Wellington, New Zealand: Crown Forestry Rental Trust.

Celant, G. (1997). Michael Heizer. Milan, Italy: Fondazione Prada.

Crone, R. (1982). Prime objects of art: Scale, shape, time. Perspecta, 19, $14-35$. 
Deckker, T. (1999). Land art: City architecture. Issues in Architecture, Art and Design, 6, 1 pp. 34-51.

D'Hooghe, A. (2011). The objectification of infrastructure: Elements of a different space and aesthetic for suburban America. MIT Journal of Planning, 10: pp.85-93.

Gissen, D. (2010). Territory: Architecture beyond environment. Chichester, England: John Wiley.

Hill, R. (2010). Resorting to force in a generally tranquil society: The police capacity to use overt coercion in post-colonial New Zealand, 1907-2007', Policing and the Policed: An International Workshop, London, England: Institute of Commonwealth Studies.

Kant, I. (2007/1790). Critique of judgement. New York, USA: Cosimo.

Kastner, J. \& Wallis, B. (1998). Land and environmental art. London, England: Phaidon.

Keenan, D. (2008). Terror in our midst: searching for terrorism in Aotearoa New Zealand. Wellington, New Zealand: Huia Publishers.

Knight, I. (2009). Māori fortifications. New York, USA: Osprey Pub.

Krauss, R. (1979). Sculpture in the Expanded Field. October, 8 (Spring), pp. 30-44.

Natusch, G. (1992). Power from Waikaremoana: a history of Waikaremoana hydro-electric power development. Tuia, New Zealand: Electricorp Production.

Park, G. (2001). Effective Exclusion - An Exploratory Overview of Crown Actions and Māori Responses Concerning the Indigenous Flora and Fauna, 1912 - 1983. Wellington, New Zealand: Waitangi Tribunal Publication.

Park, G. (2007). Theatre country: Essays on landscape and whenua. Wellington, New Zealand: Victoria University Press.

Queenstown Lakes District Council. (2011). Queenstown Lakes District Plan: Section 5 rural areas. Queenstown, New Zealand: Queenstown Lakes District Council.

Rangitauira \& Co Barristers \& Solicitors (firm). (2004). Amended consolidated particualrised statement of claim for Waikaremoana (WAl 894). Unpublished report, Retrieved from www.ngaituhoe.iwi.nz/LinkClick.aspx ?fileticket=L_8a7vp6h60\%3D\&tabid $=177$

Serra, R. \& Eisenman, P. (1983). Interview. Skyline, April, pp. 14-18.

Single, M., Shaw, W. \& Bycroft, C. (2011). Lake Waikaremoana shoreline hazard management contract report No. 2408b. Rotorua, New Zealand: Shore Processes and Management Ltd. 
Smithson, R. (1996). Robert Smithson: The collected writings. Berkeley, USA: University of California Press.

Tahana, Y. (2012, September 12). Tuhoe gets more say in giant park, The New Zealand Herald. Retrieved from Newztext Plus database.

Thorby, A. (2012, 9 March). Waiting for a bit of land. Scoop Media. Retrieved from Newztext Plus database.

Vidler, A. (2005). Architecture's expanded field. In Sykes, A. Constructing a new agenda: Architectural theory 1993-2009. (pp.318-332). New York, USA: Princeton Architectural Press.

Wood, P. (2000). Trespassers will be Eaten: The Māori Land Occupation Structures of Waikaremoana. in Ostwald, J. \& Moore, R. (eds). Re-framing architecture: theory, science and myth. (pp. 219-225). Sydney, Australia: Archadia Press. 
